STATE OF ALASKA

DEPARTMENT OF NATURAL RESOURCES

DIVISION OF GEOLOGICAL AND GEOPHYSICAL SURVEYS

\author{
Steve Cowper, Govenior \\ Rod Swope, Commissioner
}

Robert B. Forbes, Dircetor and Sialc Geolognist

August 1900

\author{
licport of Investigations 90-1 \\ CCAL RESOURCES OF THE \\ SUSITNA LOWLAND, AI.ASKA \\ by \\ R. D. Merritt
}




\section{STATE OF ALASKA \\ Department of Natural Resources \\ DIVISION OF GEOLOGICAL \& GEOPHYSICAL SURVEYS}

According to Alaska Siatute 41, the Alaska Division of Geological and Geophysical Surveys is charged with conducting "geolngical and geophysical surveys lo delermine the potential of Alaskan land for production of metals, minerals, fuels, and geothermal resources; the locations and supplies of ground water and construction matcrials; the potential geologic hazards to buildings, roads, bridges, and other installations and structures; and shall conduet such other surveys and investigations as will advance knowledge of the geology of Alaska."

In addition, the Division of Cicological and Geophysical Surveys shall collecl, record, cvaluatc, and distributc data on the quantity, quality, and location of underground, surfacc, and coastal water of the state; publish or have published data on the watcr of the state and require that the results and findings of surveys of water quality, quantity, and localion be filed; require that watcr-weil contractors file basic water and aquifer data, including but not limited to well location, cstimated clcvation, well-driller's logs, pumping tests, flow measurcments, and watcr-quality detcrminations; accept and spend funds for the purposes of AS 41.08 .017 and 41.08.035, and enter into agreements with individuals, public or privatc agencies, communitics, private industry, and stale and federisl agencics; coliect, record, evaluate, archive, and distributc data on scismic cverts and enginecring geology of the starc; and identify and inform public officials and industry about potential scismic hazards that might affect development in the state.

Administrative funclions ase performed under the direction of the Slate (ieologist, who maintains his office in Fairbanks. The locations of DCiCiS offices are listed below:

- 794 Universily Avenue (Suitc 200)

Fairbanks, Alaska $9971 k$

(907) 474-7147

-3700) Airpori Wily

Fairbanks, Alask a $\left.9(7)()^{4}\right)+\left(0^{2}\right)$

(917) 451-2760
- 4(1)(1) Willoughby Avenuc

(3rd noor)

Juncau. Alaska (x)801

(9)7) 4615-25.33

- 18225 Fish Hatchory Road

P.(). Bos 772136

Eagle River, Alaska 99577

$(907) 69(2-0070$

This report is for sale hy DGGS for \$15. DC ic;S publicalions niay be inspected at the following locations. Address mail orders to the Fairbanks office.

-3700 Airpore Way

Fairbanks, Alaska (997(19)

- U.S. Geological Survey

Earth Science lorormalion Center

605 Wesl 4lh Avenue, Roon (i84.

Anchoragc, Aliıkai
-400 Willoughby Avenue

(3rd hoor)

Juncilu, Alaska

- U.S. Cicological Survey

Earth Science lnformution Center

42.31) Universily Drive, Room 101

Anchorage, Alaska 


\section{CONTENTS}

Yage

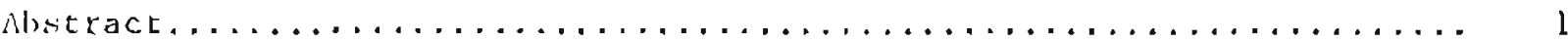

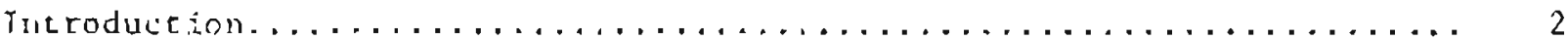

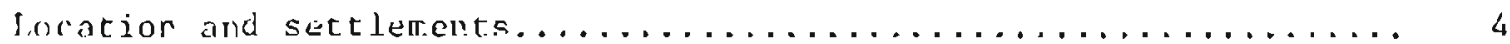

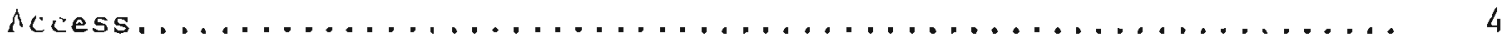

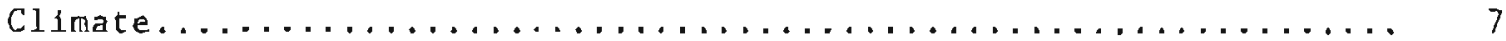

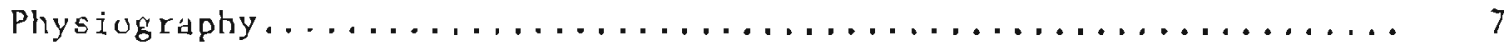

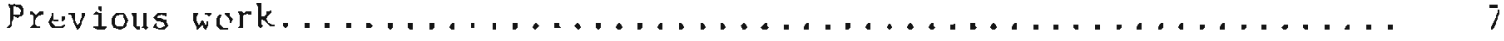

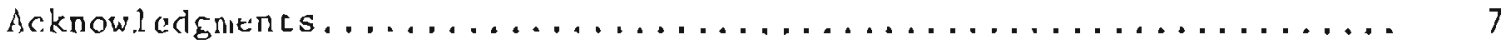

Structura] geology and regiunal tectonism................... 8

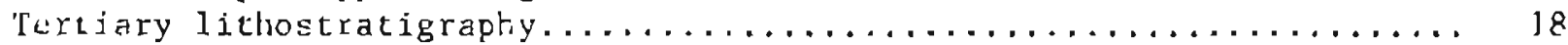

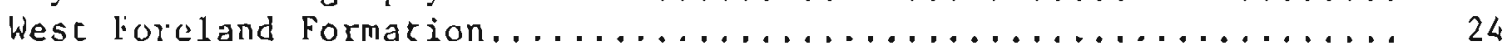

Hemiock Conglomelate................................ 26

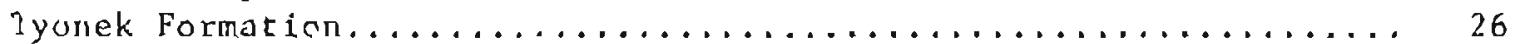

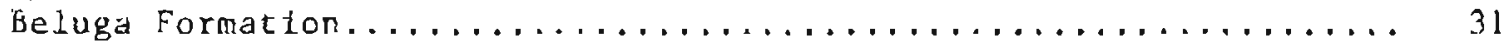

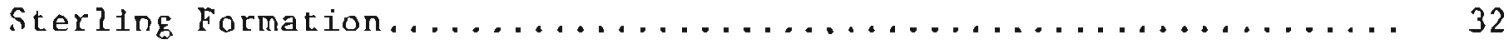

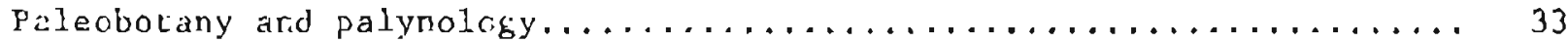

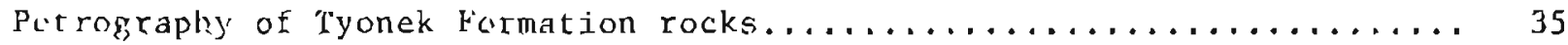

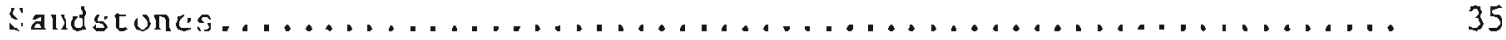

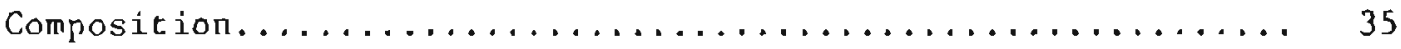

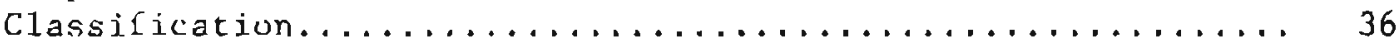

Roundness, sorting, and textural maturity............ 36

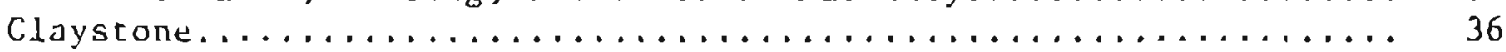

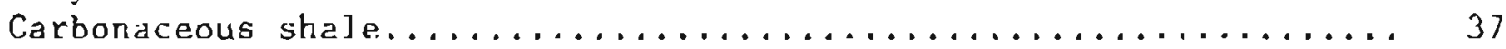

Carbonate content and concretions...................... 37

Tonsteins..................................... 37

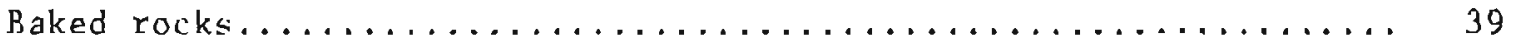

Depositional enviroments of Kenai Group coals................. 41

Coal petrology..................................... 49

Coal-pellet preparation and petrologic analysis............. 49

Maceral composicion............................... 49

Palcoenvironmental interpretation for maceral compositions and

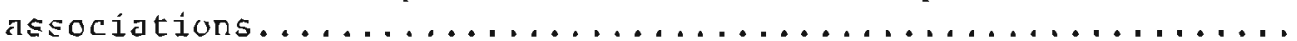

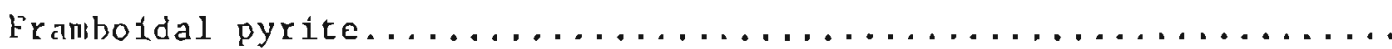

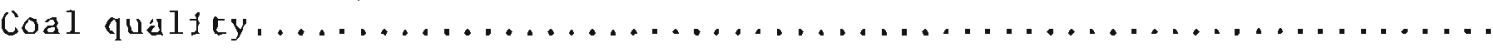

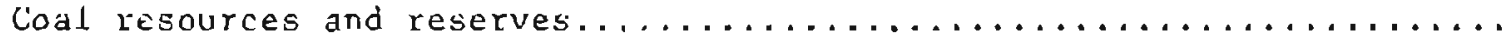

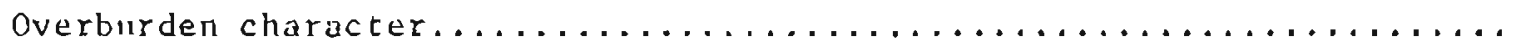

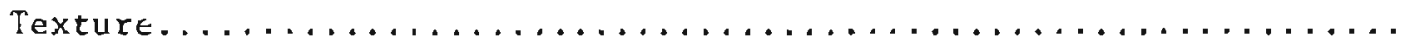

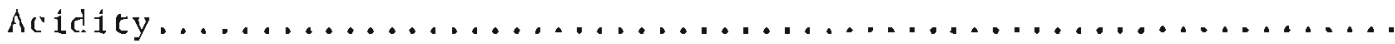

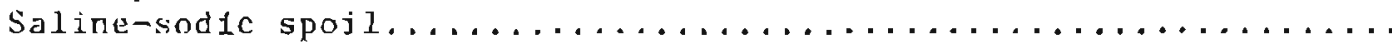

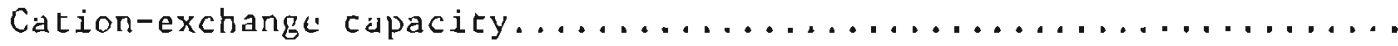

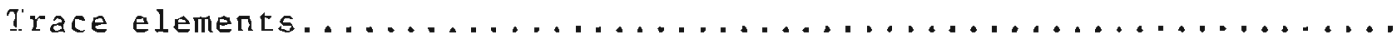

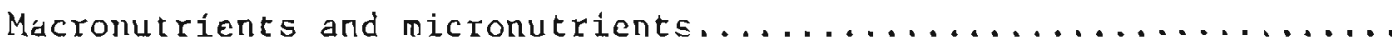

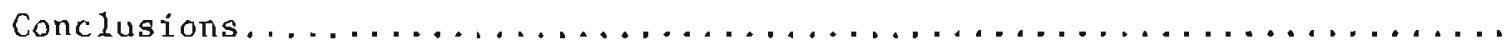

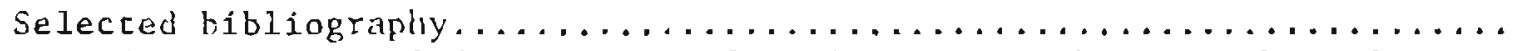

Appendix A - General description of coal outcrops shown on sheet 1

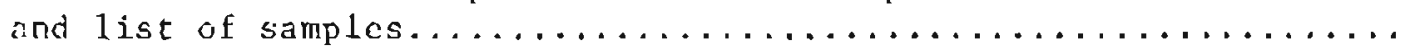

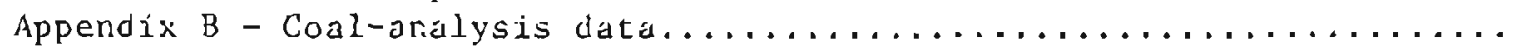

Appendix C - Geologic columns with sampling locations for described

cual-bearing sections within the kenai froup................. 
Appendix D - Calculations for statistical Markov chain dnalysis........ 169 Appendix E - Overburden-characterizatinn data................. 173

\section{FIGURES}

Figute 1. Location map of major coal basins and isolated coal

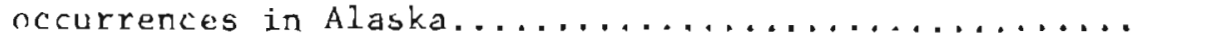

2. Perspective block diagram showing general location and physiographic selcing of the Susitma lowlard........

3. Regional index map showting main geographic features, trarsportation routes, and major political boundaries in southcentral Alaska......................

4. Map of major tectonic elemerts that outline the geologic sttting of southcentral Alaska..................

5. Structure sections based on geophysical profiles across the beluga basin and adjacent areas...............

6. Map of major 'Tertiary basins of the Cook Inlet-Susitna

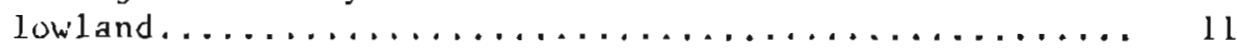

7. Simple Bouguer gravity map of the Buluga basin and

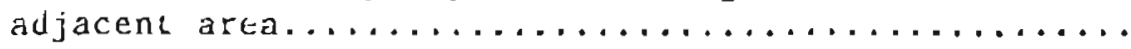

8. Map of mujor fault syscems in the Shelikof trough

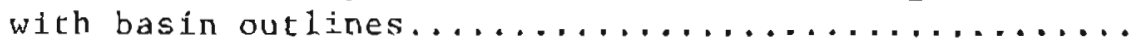

9. Map of structure contuurs, coal outcrops, and coal lease areas, Chuitna district, southern Susiena lowland..... 14

10. Structure section between Capps Glacier and the lower Chuitna River.........................

1). Generatized geologjc cross sections of areas along the hestern margin of the susitna lowland.............

12. Map of tertiary depocenters, and oil, gas, and coalfields in the Conk In let-Susilna low land area............

13. General stratigraphic nonenclature for the l'ertiary kendi Group of southcentral Alaska...............

14. Generalized isopach map of Tertiary deposits in the Cook Inlet-Sustena lowland area.................

15. Primary eiements of a Tertiary model fur the Cook

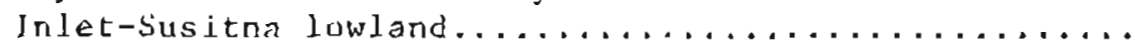

16. Photograph of coal-bearing Tertiary sedimentary rocks (Beluge Formation) exposed along a $15-\mathrm{km}$ outcrop at Beshta Bay, Cook Inlet, Alaska................

17. Correlation chart of surface and subsurface Tertiary stratigraphy for five coal-bearing regions in

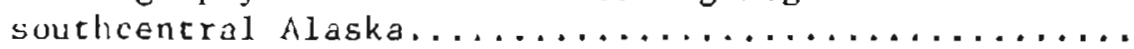

18. Lithulogic and geophysical logs of the type section

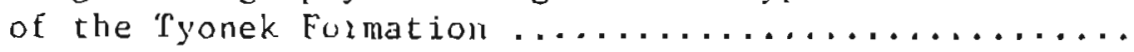

i9. Generalized lithologic log from test hole near Capps Glacier showing stratigraphic positions of the Capps and Waterfall coal beds..............

20. Ceneralized cross section of the Beluga coalfield in the Capps district, showing thicknesses of Capps and Waterfall beds and overburden and interburden zones... 
21. Photograph oi the Chuitna bed ('Brown Scam') outcrop

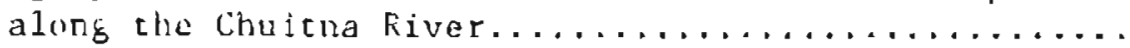

22. Photograph of the Fairview Moullain coal beds, northwest susitna lowland....................

3. Photograph of volcenic ash partings in the Capps hed, Belugo coalfield.................... 32

24. Map showing Seldovian and Homcrian Stage fossil localities in the Susitno lowland............... 34

25. X-ray ditiractogram of ccal tonstein from the Capps bed... 38

26. Phetograpl of gradational zones of burn material. in a coal-bearing section of the Tyonek Formation, upper Canyon Creck, souchwest Yentna basill..............

27. Generalized vertical sequence of continental fluvial

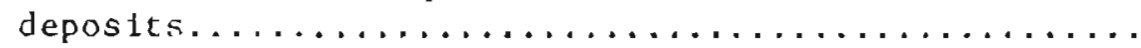

28. Block diagram for continental fluvial environments typical to the susitna lowland.................

29. Photograpli of in-place, uprighte tree stump in woody coal (Keluga Fomiation) along the Beluga River, southern

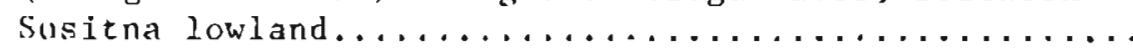

30. Ceologic cross section of a lacustrine deposit in

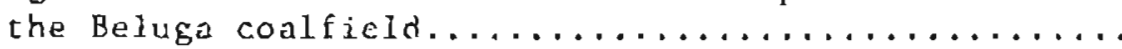

31. Diagram of probabilities of various transitions in lithology in a coal-bearing section of the

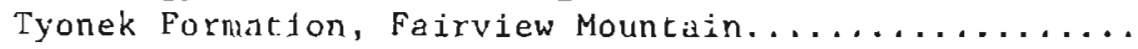

32. Stratigraphic column showing variation in ammonium acetate extractable cations and total cation-exchange capacity (CEC) for a coal-bearing section in the Peters Hills area (east Yentna field)...........

33. Ternary diagrain for maceral-group compositions of Susitna lowland coal samples..................

34. Photomicrographs of lertiary coals from Coal Creek, Johnson Creek, and Peters Hills area showing huminite and liptinite macerals......................

35. Photomicrographs of Tertiary coals from Beshta Bay, Coal Creek, ard Fairview Mountaln showing pre-

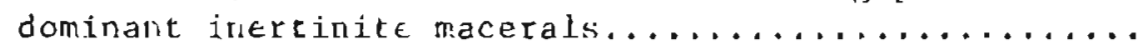

36. Histogram of vitrinice reflectance frequency as measured from ulminite macerals in coal samples from the

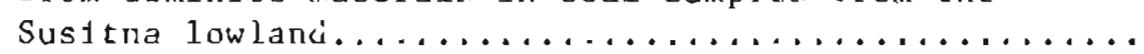

37. Enur-component 'facies' diagram of individual microlithotypes as percentages of different petrographic

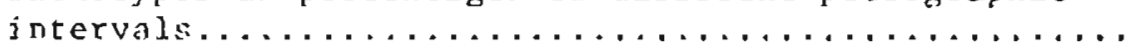

38. Photograph of coal seam exposed along the Talachulitna River, westcentraj. Susitna lowland..............

39. Histogran showing maximum observed and arithmetic-mean values for the percent total sulfur and sulfur species of uralvzed Susitna lowland coal samplcs.....

40. Map showing genera! Jocation and Iithologic descriptions of two lieasured coal-bearing sections of the Beluga

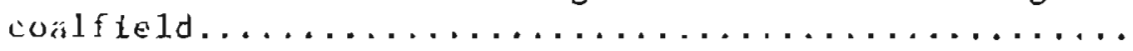


41. Diagran shuwing range of crace elument concentrations in rav coal ashes commonly found in uther coals rompared to range of those in Susjtna lowland coals... 64

42. Eistugracs of various coal-quality parameters of analyzed coal suriples from the susitna lowland....... 65

43. Scatler plots vith regressiun lines of paired proximate variables for analyzed coal samples from the Susitna

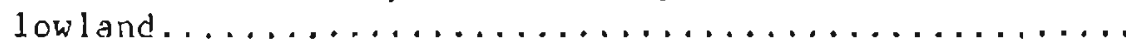

44. Cluster analysis based on proximare data, total sulfur, ard heating values for analyzed coal samples from

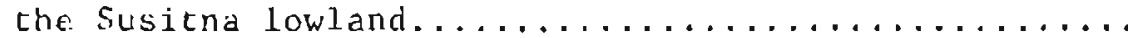

45. Diagram showing range of major-oxide concentrations in raw coal. ash Eror eight localities in the Susitna low lind...............................

46. Coul-resource classification system of the U.S. Bureau

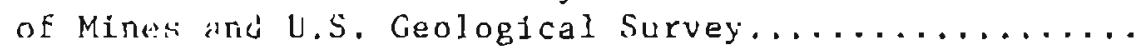

47. Map oi the Susitna lowland showing arcals with favorable strip-nining conditions................... 71

48. Map of the Susicna lowland showing locations of major coal leases............................

49. Photograph of coal bed exposed along Johnson Creek, western margin of the Susitnd Lowland..............

50. Photograph of coal-bearing scclion along Short Creek,

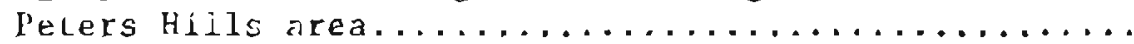

51. Photograph of gleys weathering from burn material in a coal-bearing section of the ryonek Formaticn, Chuitna River, Beluga coalfield.................

52. Telnary diagram of particle sizes and textures of overburden samples trom the Susitna lowland, showing rock materials that tend to form zones of poor texture in spoid miterial...............

53. Graph showing range of unconfired compressive strength for Capps district coal samples.................

54. Histograms of $\mathrm{pH}$ and total-suliur content for overburden

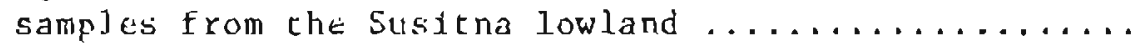

55. Nagram showing overburden-interburden characteristics for a coal-bealing section from Fairview Mountain,

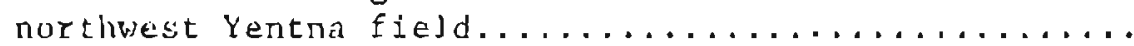

56. Liagraut showing range of certain trace elements in overburden materials at six sites in che

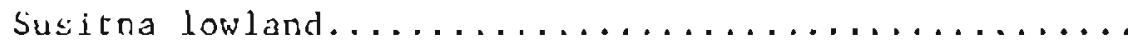

T ABLES

Table ]. Tentative correlation of geologic units, Keráli

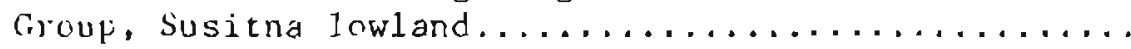

2. Sunmary of chicf characteristics of icitiary and Cretaceous sedimentary rock formations of the I.itcle Susicna district and lower Matanuska Valjey............................... 
3. Major oxide geochemistry oi two coal tonstejns frulu the

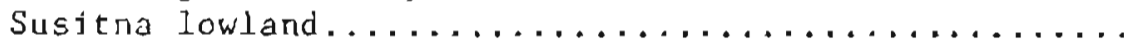

4. Major-oxide geochenistry of a gradational series of baked rocks from in upper Canyon creek locality......

5. Criteria for recognition of tiluvial depositional

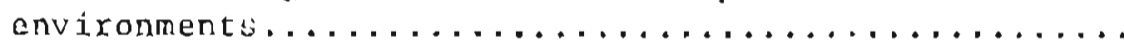

6. Nomenclature and characteristics for major brown coal-

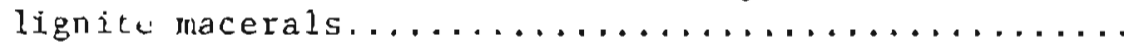

7. Summary of maceral composition of 180 coal samples from

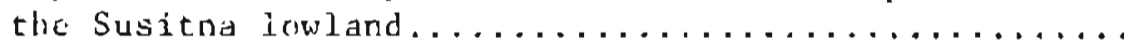

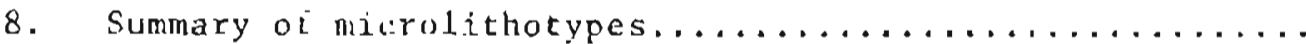

9. Chipf characteristics of autochthonous and allochchonous

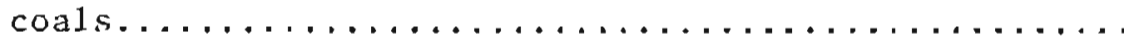

10. Total sulfur and sulfur species of selected coal seams

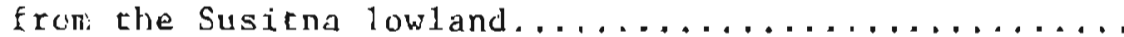

11. Average quality of Beluga fjeld coals..................

12. Net coal thicknesses and assay data for major coal seams, Chuitna kiver field, Alaska................

13. Coul-qualjty data, Johnson Creek and Canyon Creek

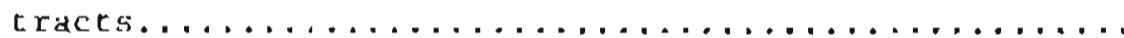

14. Ayalyses of 16 coal samples Erom the Beluga-Yentna

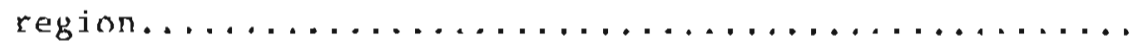

15. Proximate and ultimate analyses of raw coals, Waterfall and Sunflower creek seams.....................

16. Vitrinte-rellectance data, Wacertall and Sunflower

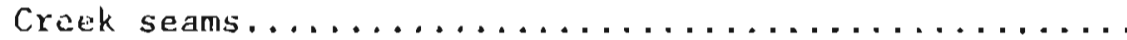

17. Sumiary ui range and mean values and coal-quality characteristics of 66 samples from the Susitna

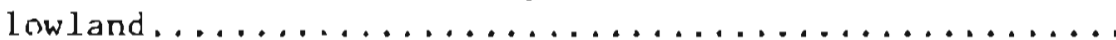

18. Result of ultimate analyses, in percent, of selected

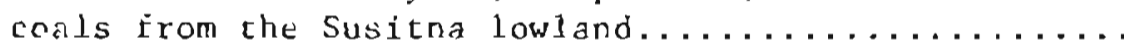

19. Estinated identified coal resources for several major seams in the Beluga area..................... 73

20. Peters Creek drill data........................ 74

21. Miliable reserves, Beluga coalrield................. 75

22. Sum:mary, overburden-characterizatinn analyses of Susitra lowland samples................... 78

23. Geuchemical parameters neasured in determining the levels of soluble salts and sodfum in snils and overburden...

21. Geometric means for certain crace-element contents ill overburden samples from the Susitna lowland, Capps coalfield, and suitos from other areas in the conterminous United States..................

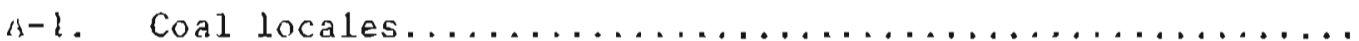

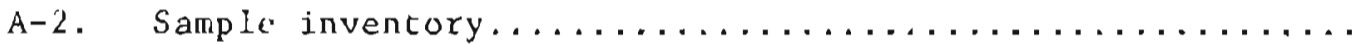

A-3. Specific location informatfon for Susitna lowland coal and overburden sampling siles...............

E-1. Concentration uf major oxides in ash of raw coals........

B-2. Concentration of tract elements in raw coal aslies......... 
6-3. Vitrinite-reflectánce data as measured from ulminite macerals, selected Susitna lowland coals........... 126

B-4. Relationship between rank and vitrinjte reflectance...... 127

B-5. Calculations relating to coal quality................ 128

B-6. Classification of coals by rank.................. 130

B-\% Total sulfur, selected Susitna lowland coal samples...... 131

B-8. Sulfur species, selected susitna lowland coals.......... 132

B-9. Ast and chemical analyses on coal from the Beluga field, as-received basis................... 132

B-10. Chemical analyses on coal ash, major oxides, and chlorine of coal lrom the Belugd field............. 133

B-11. Proximate analyses, ultimate analyses, and calurific value of coal from the Be]uga field..............133

R-12. Chemicall analyses on coal-ash trace elements in coal from the Beluga field..................... 134

b-13. Fusibility of ash and sulfur forms in coal from the

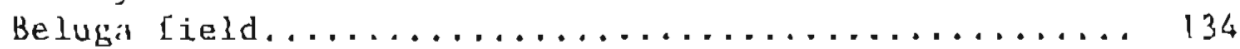

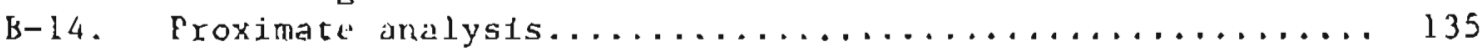

$\mathrm{F}-1$. Overburden procedures and refierences................ 175

E-2. Physical and chemical data on overburden, Beluga River

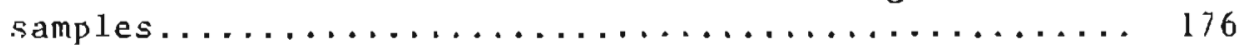

E-3. Physical and chemical data on overburdell, Fairview Mountain samples....................... 176

E-4. Chemical data on overburden, Canyon Creek site.......... 178

L-5. Chemical duta on overburden, Johnson Creek samples....... 178

E-6. Chemical data on uverburden, Wolverine Creek samples..... 178

E-7. Physical and chemical data on overburden, Peters Hills

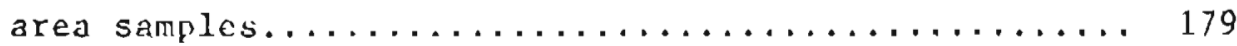

E-8. Chemical data on overburútn, Saturday Creek samples...... 180

E-9. Chemiral data of overburden samples from Capps district... 180

E-10. Suitability ratings for soils as sources of topsudling material in Wyoming...................... J81

E-11. Suspect levels ir. overburden moterial of Montana......... 181

\section{SHEETS}

Sheet 1. Coal-geology and structure map of the Susitna In pocke: lowland

2. Continental fluvial models and paleoenvironments of In pocket coal deposition

3. Coal-potential map of the Susitna lowland In pocket 


\title{
COAL RESOURCES OF THE SLSIJNA LOWLAND, ALASKA
}

\author{
Roy D. Merritt
}

ABSIRACT

The Susjtna lowlena of southcentral Alaska contains major reserves of subbltuminous and lignite coals within the Kenai Group of Itrtiary age; these reserves cocur mainly jn the Tyonek formacior. The Susitnd lowland contains tha second largust coal-resuurce bast in Alaska, surpassed nnly by the nurthern Alaska deposits. Lstinaten of resources and reserves vary widely, but cutal mirible reserves are undoubtedly several billion tons. Most of the knoum resources occur in a crescent-shaped belt along western ond souchern margins of the Susitia lowland.

Runai Group coals formed in paleoenvitronments associated with continental fluvial depusitional systems. Rapid lateral and vertical changes in lithology often make correlalion of coal beds difficult, even over distances of $1,000 \mathrm{~m}$. Hetrologic studies indicate that most of the Susitna lowland coals originated in Eorest-moor environments during a fairly temperate (warm and moist) climatic period. Peat-furming episodes that occurred during lulls in regional teclotic activity were interrupted by the rejuvenation of adjacent highlands of low to moderate relief ind the shedding of clastjc sedinents into backswamps.

Susitna lowland coals are comparable in overalj quality with those of the Powder River basin of the western lnited States. The sulfur content of Susitna lowland coals is excremely low, $\cong 0.3$ percent, and ash content is variable but averages about 15 percent; mean heating value is about 8,200 Btu/1b (all on as-recelved basis). Concentrations of erace elements that could volatilize during combustion, such as mercury, ancimony, uranium, and thorium, are relatively low. hut sodium, vanadium, and barium sometimes uccur at higher levels.

Coal overburdens of the region are also low in pyrite and sulfur $(<0.5$ percent); as with the coals, suifur occurs mailly in the organic species. Mincr quantities of framboidal pyrite, present as pyritic sulfur, were documented in certain overburden samples. Some overburden samples had relatively high percentages of the crace elements boron, lead, zinc, molybdenum, nickel, cobalt, and cadmiul. However, the serious acld conditions commonjy associated with eastern and midwestern U.S. coal mines and the high levels of soluble salts and adsorbed sodium in western U.S. coalfields are not likely to be significant froblems.

liarge-scale surface mining in tho Susitna lowlane will probably begin within the next decade. At that time, material textures in mine spoils, particularly clays and weathered gleys, may become a signilicant problem for proper drainage and revegetation on certain cracts. In addition, stream siltation may occur locally; in areas of perched ground water or springs, de-watering of trenches and pits will be necessary.

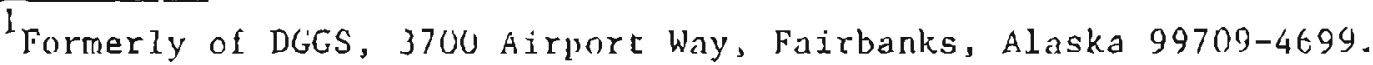




\section{INTRODUCTION}

Covernment and industry have sporadically investigated Aluska coals since about 1900. Lniform resource and reserve figures and information un geology and extent of most occurrences are scarce, but existing eviderce indicates extensive coal resources in Alaska. In 1979, U.S. Department of Energy reported a demonstrated Alcskin coal-rtserve base of 6 billion tons. In conerast to the Cook Inlet and the Kenai Peninsula, which have been cxtensively drilled for oil and gas and Intensely studied, the subsurface of the Susitna lowland is relatively unexplored, and its structure and stratiglaphy are poorly understood. Lstimatcs of total coal resources--inferred and hypothetical--have variec lrom 2 to 5.5 trillion tons (McConkey and others, 1977).

Despite these immense resources, coal production has been minimal because of the remcteness of deposits and lack of markets. During the early part of this cencury coal wis produced on a snall scale from numerous sites lor local uet and for ship fuel; substantial quantities wert produced fron, the Mutaruska coalfield (fig. l) for the Anchorage market until nacural gas from Cook Inlet supplanted ic in 1967 (Conwell, 1972b). Coal production in Alaska is limited now to the Usibelli Mine, which produced about 1.5 million tons trom the Hosannd creek field of the Nenana basin in 1986.

The high cost of petroleum fucls and uncertalnty of supply have created strong interest in Alaska's coal resuurces and their feasibllity for local use, export, and generation of syncheric fuels. Accordingly, DGGS Ls investigating and assessing coal resources of the state.

The purposes of these investigutions are to aid in land classiffcation and management, to facilitate issuance of coal-prospectine permits and coal leases, to deternine more accurately the extent of coal reserves and their potential for development, to address numerous inquiries from industries who are interested in developing the resources and from Eucific Rim countries seeking coal supplies, and to provide a single information sourct on coal deposits of an arci.

The first region selected for study is the susitna lowland, a broad area drained by the Susiena River and its tributaries. Beds of subbituminous and lisnite coal exposed along major drainages of the lowland and southern foothills of the Alaska Range indicate abundant, relatively shallow, subsurface cual deposits. Explolatory drillirg by leaseholders in the southwestern Susitna lowland has proved major coat reserves suitable for surface mining. Baines (1966) estimated the coal resources witlin the Beluga-Yentna region at 2.4 billion tons in beds over $0.75 \mathrm{~m}$ thick; of these resources, 2.1 bijlion tons are concentrated in the Beluga and Chuitna River basins.

The strategic location near tidewater, the thickncss, extent and quality of the nuoverous coal seams, and characteristics of the overburden, the interburden, and the seatrock cumbine to make deposits of the Susitna lowland-and particularly those in the southern area--tle most economically atcractive for near-term, new-mine development in Nlaska. Coals of the Matanuska field will undoubtedly be mined anew in the near future, and those could be blended with the lower-Btu coals of the Susitna lowland co upgrade the product. 


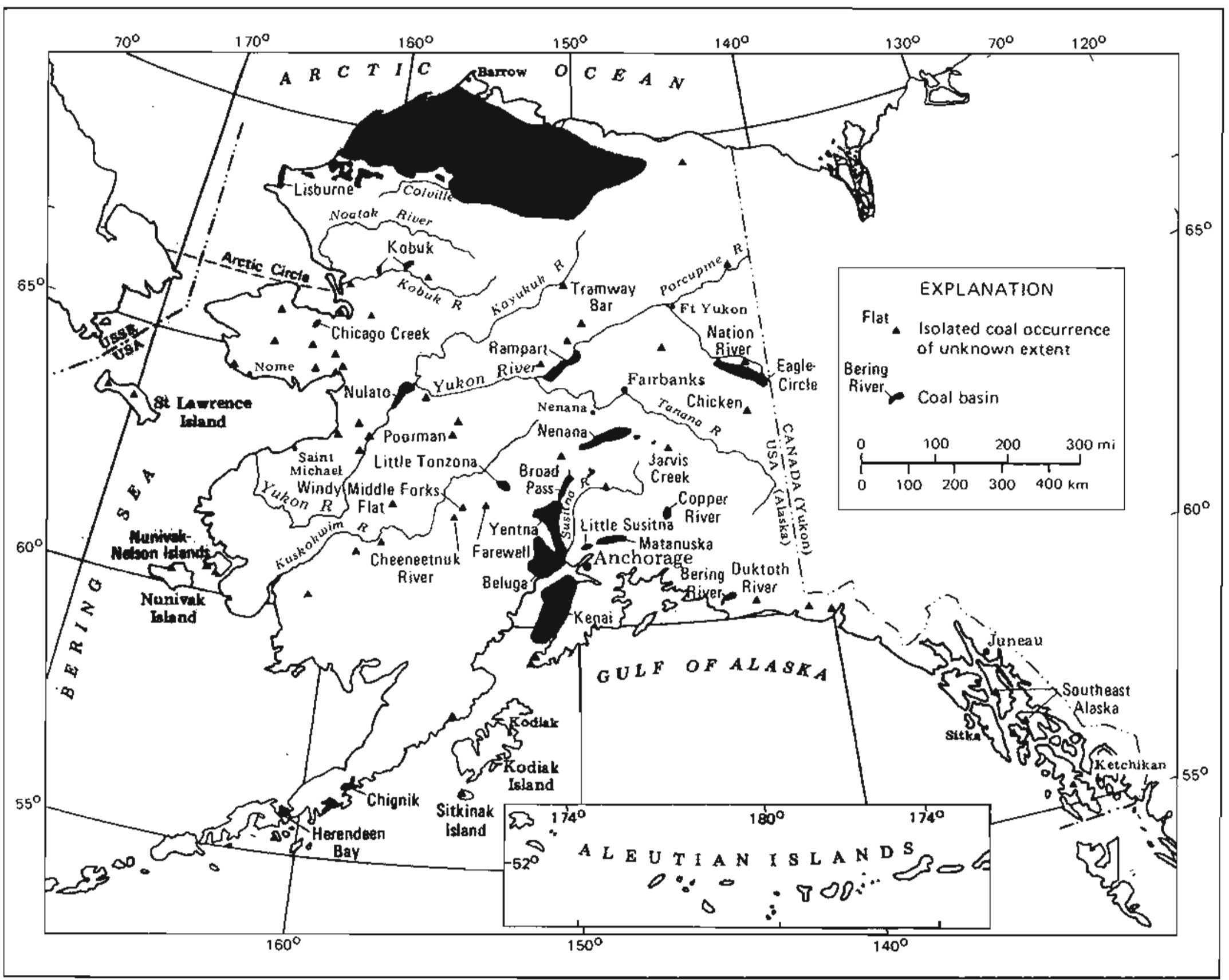

Figure 1. location map of major coal basins and isolated coal occurrences in Alaska. Modified from Barnes (1967) and Conwell (1977a). 
The Susitna lowland contains several coalfiejds, all of which are of similar egc and character. Because discontimuous outcrops and lack of subsurface data precluat cietailed study for most oi the Jowland, this study wild focus on regional basin allalysis.

The Susitna lowland was selected for three reasons: ( 1 ) it contains the Capps and Chuituid districts of the Beluga coalfield, which have the highest potential for near-term large-scale production in Alaska; (2) enough geologic Jata exist to make the fleliminary compilation without extensive field work; and (3) the statc has received numerous applications for coal-prospeccing permits and needs information on that area's coal potential.

Location and sectlements

The entire Cook Inlct-Susitna lowland Tertiary province (Wahrhaftig, $1965)$ is about $515 \mathrm{~km}$ long by $130 \mathrm{~km}$ wjde. The Susitna lowland encornpasses about $13,000 \mathrm{~km}^{2}$ (ffg. 2). Bounded by the arcuare $\Lambda$ laska Range on the north and west, the lalkeecna Mountains on the east, and Cook Tnlet on the south, the lowland extends from the Matanuska-Susitna Borough into the Kenai Peninsulu borough ( $\mathrm{fig}$. 3). Because the Susitna lowland includes the northern fart of Cook Inlet, some authors (Milier and others, 1959) have considerfd th the northwestern extension of the Cook Inlet Tertiary basin. Barnes (1966) called the area the Beluga-Yentna regton. Elevation ranges from sea level at Cook Inlet co about $300 \mathrm{~m}$ at the northern margfn. Isolated uplands of intrusive and pre-Tertiary roclis rise to $1,200 \mathrm{~m}$ above surrounding Jowlands.

The Castle Mountain faulc, a major northeast-trending discontinutty, separates upper Cook lnlet on the south and the Susitna lowland on the north. Most stratigraphic studies in the cook Inlet petroleum province terminate at the fault; however, important cual leases in the Beluga lield lie on both sides of the fault zone. Work during che past several years by ledseholders in the southwestern part of the lowland indicates the Beluga coalfield contains three separate coal deposits: Capps, Chuitna, ano Threcmile districts.

The upper Cook Inlet region, site of metropolitan Anchorage and nearby settlements in the Matanuska Valley and Kenai Peninsula, is the most densely populated reglon in Aleskia. The state's principal agriculcural reglon is located in lower Matanuska Valley, and additional lands are being readied for ayriculture near Mackenzie Point, across Knik Arm from Anchorage. Except for small settlements along the Parks Highway and the Alaska Rallroad, the Suslcua lowland is essentially uninhabited. Summer activity includes placer mining in the letersulle-Cache Creek area in the northern part of the lowland and drilling on the active coal leases in the southwestern lowland.

\section{Access}

The Parks Highway and the Alaska Railroad trälisect the Susitna lowland in a north-south direction rough]y paralle]ing the susitna kiver, cunnece the ports at Anchorage and Sewald with falrbanks in the interior, and pass through the Susitna. Matanuska, and Broad iass coilfields (fig. 3). Because of accessibjlity to rail and ocean transportation, the Susitna lowlarid has been a main coal-exploration target of industry. The Parks Highway and a l6-km-long extensicri to Talketna are the main paved roads in the area. A 50-km-long gravel 


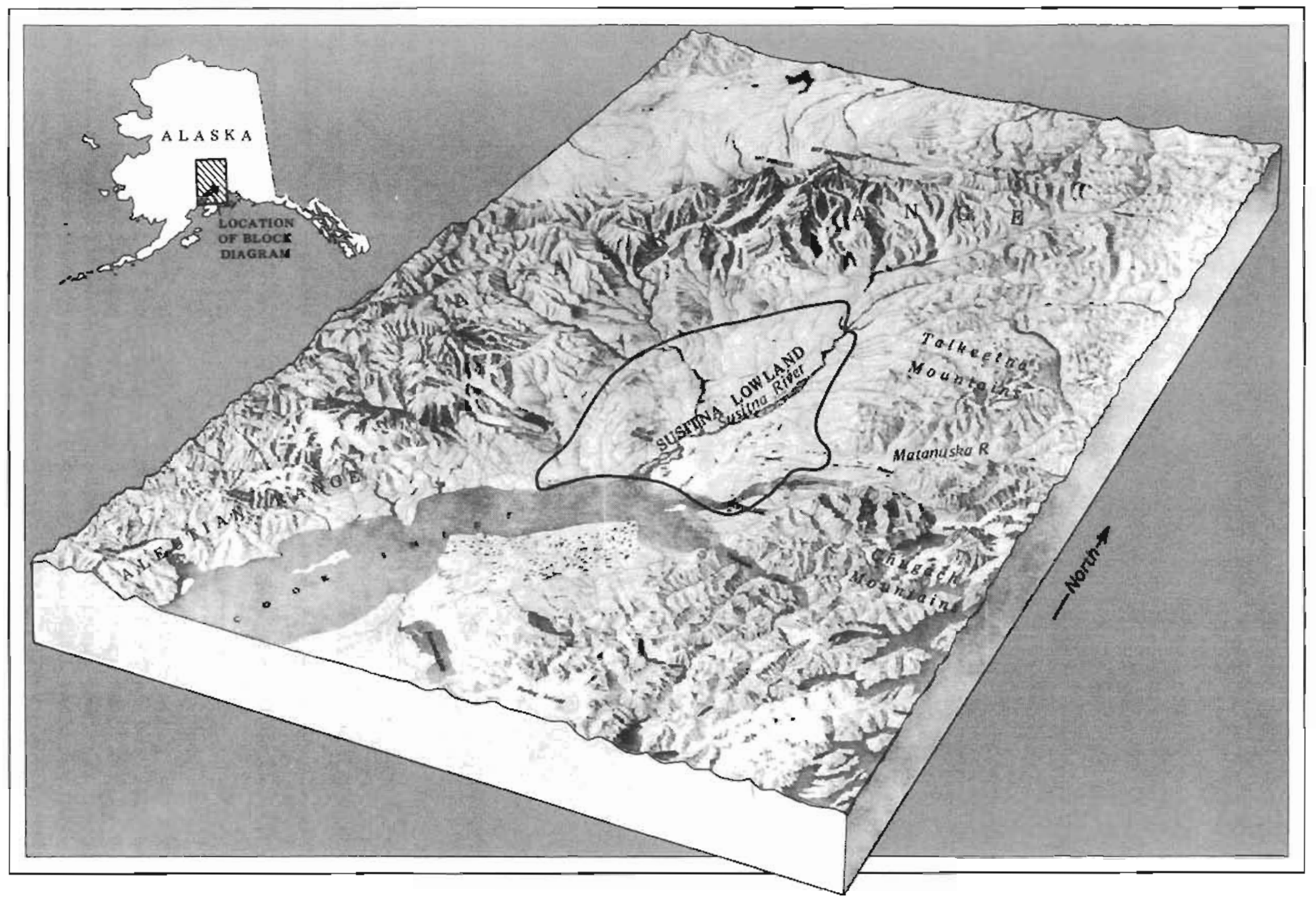

Figure 2. Perspective block diagram slowing general location and physiographic setting of the Susitna lowland. Medifted fron Miller and Dobrovolny (1959). Vertical exaggeration about $4 \mathrm{x}$. 


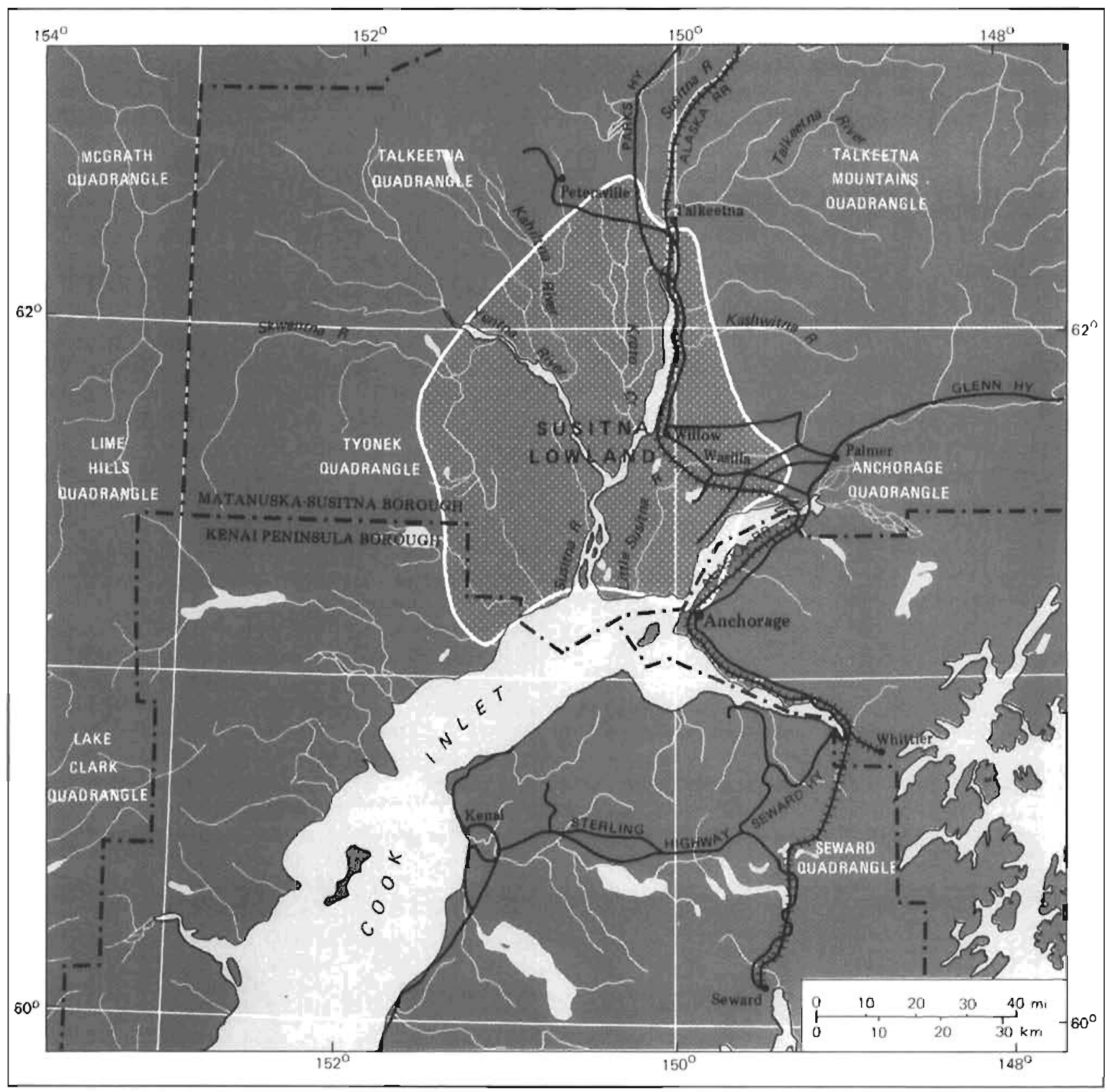

Figure 3. Regional index map showing main geographic features, transportation roules, and major political brundaries in southcentral Alaska.

road connects the placer-mining district on Peters and Cache Creeks northwest of Talkeetna with the Parks Highway. Most of the remaining lowland is accessible only by aiccraft or riverboat; helicopters are generaliy used for field investigations. Surface conditions and environmentel restrictions limit the use of off-road vehtcles. A few private landing strips of varying quality lie near some of the mining claims, but permission is required for their use. Public facilities are available at Talkeetna. 
Climate

The climate in the Susttna lowland is less severe than in the interior, but heavy snowalls and strong winds are not unusual during vinter. Average annual precipitation at Talketra is $71 \mathrm{~cm}$, and the mean temperature is about $0^{\circ} \mathrm{C}$; Anchorage incerrational Airport averages are $38 \mathrm{~cm}$ and $2^{\mathrm{c}} \mathrm{C}$, respectively (U.S. Department of Commerce, 1968).

Fertians (1965) indicated that the lower areas of the southern Susitna lowland are generally free of peimefrost. Permafrost occurs in isolated masses at internediate elevations alid is discontinuous in the mountains.

\section{Physiography}

The terrain of the coitral susitna lowland is broad, relatively flat to slightly irregular, and increases in rellef toward the foothills. Schmoll and Yehle (1.978) classifice the physlographic and geologic features of the Beluga ared into: (1) high mountains and foothills of Hesozolc and Jower Tertiary r:etamorphic and igneous rocks; (2) an adjacent plateau underlain primarily by Tertiary coal-beartng rocks with a generally thin, discontinuous cover of Quaternary-Tertiary(?) glacinl deposits; and (3) lowlands underlain by thick Quateriary deposits--principally estuarine and fluvial--that are separated from the plateau by major escarpmentis.

Large glaciers approach the margins of the Susitna lowland. During Fleistocene time, at least five glaciations affected the lowland (Karlstrom, 1964; Nelson and Reed, 1978); evidence indicates chat ice filled upper Cook Inlet to elevations of over 1,200 $\mathrm{m}$ (Kärlstrom, 1965). Retrtating glaclers from the Susitna lowland left a landscape dominated by fluted moraines, drumlins, kettle lakes, ponds, marshes, bogs, and scoured bedrock (Karlstrom, 1965). Perlglacial activity and mass movement created valley features of talus slopes, landslides, avalanche chutes, and rock glaciers. Fluvial and other processes continue to modify the floor of the lowland.

Previous work

Geologfc investigatjons and reports of coal in the Susitna lowland were made by the U.S. Geological Survey as early as 1900 (Barnes, 1966). Vartous factors--the 1957 discovery of oil and gas in the cook Inlet basin at Swanscn River, an increasei interest in the coal and agricultural potential of the region, 1and selections under the Alaska Statehood Act and the Alaska Native Claime Settlement $A C C$, and atternts to move the state capital to Willow--have resulted in numerous reports cli the ellvironment and resources of the region; many are cited in this report. The most thorough report published on coal in the Susftna lowland is by Barnes (1966).

\section{Acknowledgments}

Many individuals contributed to this report. G.R. Eakins and j.C. Clough of the Alaska Division of Geological and Gecphysical Strveys (DGGS), coauthors of the preliminary report, performed much of the inicial compilation at the Courdation of this report. J.E. Cajlaher. Deputy Minerals Manager (Onshore Resource Evaluation) of the Bureau of Land Management Minerals vianagement 
Ufice (Anchorage), D.k. Maneval, University of Alaska School of Mineral Industry, and R.D. Reger (DGCS) carefully reviewed the orjginal manuscript and made many helpful suggestions. J.E. Sperber took the outcrop photographs and prea pared the detajled bibizography. G.K. Tommos performed the petrographic modal analyses on overburden tock samples. M.A. Belowich and $K$. L. MacDonald drafted sevelal text flgures. Tables and appendixes wele eypeset by $R$, A. Mann (DGGS). Finaje eajting, layout, and production was performed by A,F. Seward (DGGS).

The assistance of the following are greatiy appreciateo: B. I, G. Patsch of Beluga Coal Company; J.W. Blumer of Mobil 011 Corporation; Charles Weir and Pat Wiram of AMAX Coal Company (Meadowlark Farns); P. D. Rao, Jane Smith, and Rena Micfarlane of the Iniversity of Alaska Mintral Industry Research laboratory; M. A. Wiltse erd the DGGS Public Assay Laboratory staft; J. V. Thomas, hyoming Analytical Laboratories, Inc.; J. R. Rogers, Front Range Laboratory, Inc.; D. M. Triplehorn and D. B. Hawkins, University of Alaska Department of Geology and Geophysics; Cook Inlet Region and Tyonek Native corporations; and pllots of Irans-Alaska llelicopters, Inc., Anchorage.

\section{STRUCTURAL GEOLOGY AND REGIONAL TECTONISM!}

The Susitna lowland iti an embayment or extersion of the Cook Inlet back arc basin, or incermoncane half graben. Ke1ly (1963) concluded that the lowland is separated from the cock Inlet basin by a partially buried ridge of granitf.c rocks. The major synclinal axis of the cook Iniet basin bifurcates northward; one arm extends into the Yentna region, the other northeastward into the Matanuska Valley. These pull-apart extensional basins, or rift valleys, are typically filled with continental deposits and characterized by numerous discontinuous coal seams.

Payne (1.955) recognized Hivc arcuate Mesozoic cectonic elements in southcentral Alaska: (1) the Chugach Kountains geosyncline, (2) the Seldovia geanticline, (3) the Matanuska geosyncline, (4) the Talkectia geantic]ine, and (5) the Alaska Range geosynclire (fig. 4). The Shelfkof Trough, which includes the Susitna lowlana, is a Cenozolc structure superimposed on these five Mesozolc fcatures. During widespread orogeny at the end of the Cretaceous Period, the Talkeetna rountains restrlcted part of the Mataruska geosjecline and became the eastern boundary of Sheldkof Trough (Cates and Gryc, 1963).

According to Hackete (i976a, 1977), Tertlary baslus of the upper Cook Inlet region replesent a system of tilted horsts and grabens produced by extensional fragmentation of a pre-Tertiary basement (fig. 5). He postulated that substantial translational and rutational block movements occurted in southcentral Alaske during Lace Cretaceous and early Tertiary time, caused by a change from normal to oblique subduction between major plates (1976a). continucd oblique rlfting during middle to late Tertiary time further accentuated these basins. Hackett (1977) recognized several subbasins within the regtor and interprered the Cook intet, Beluga, and Yencna basins as rhombochasnie; that 1s, fatallel-sided gaps in the crust caused by dilation (fig. (6). In dextral rhombochasins, the crustal blocks are moved apart with a right-hand lateral component. Hackett interpreted the Sustene basin and tle liatanuska Valley as sphencchasms, or triangular gaps separating two crustal blocks wich fault margins that converge to a point. Carey (1958) concluded that a sphenochasm originates from rotation of one of the blocks. 


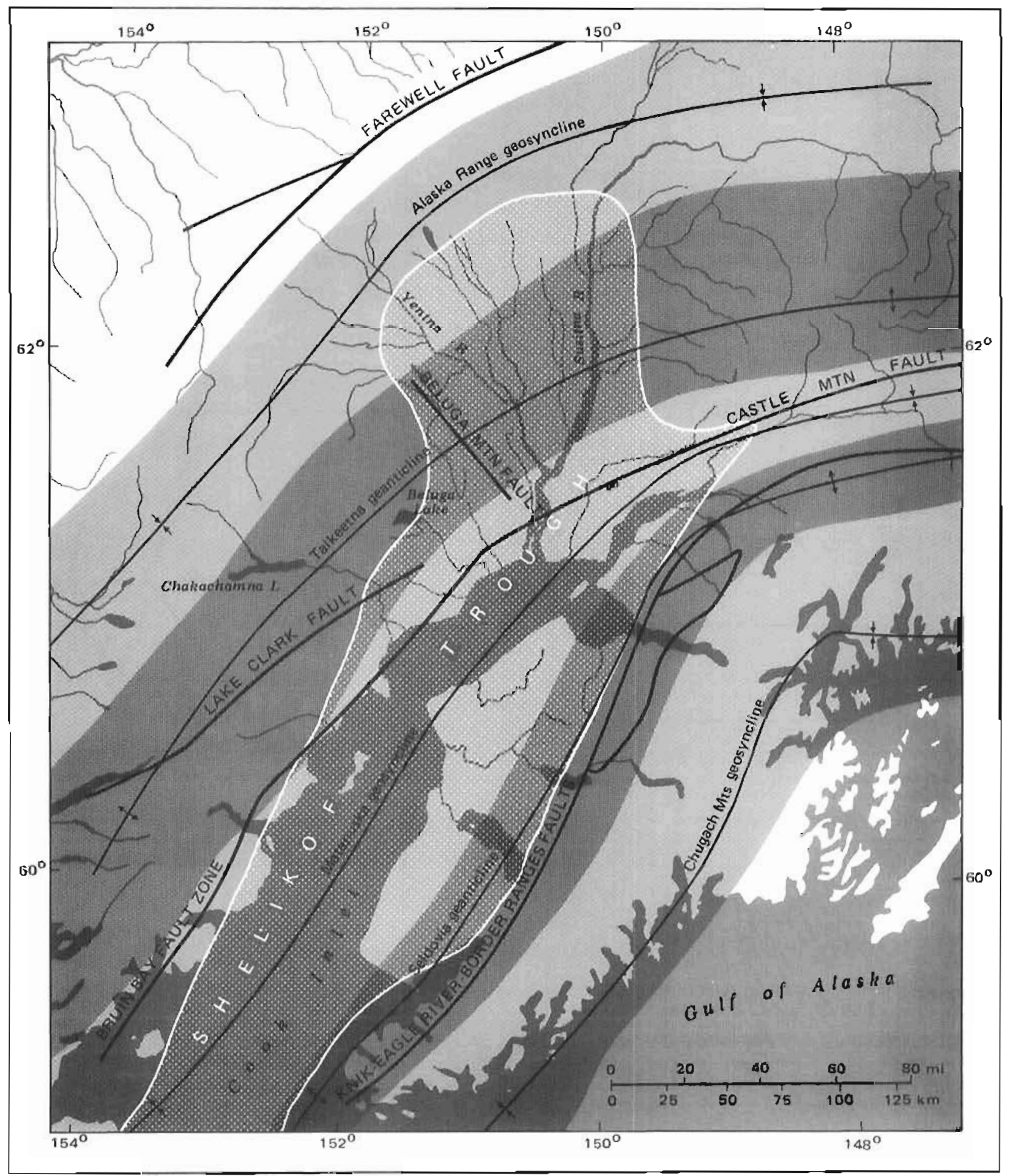

Figure 4. Major tectonic elements that outline the geologic setting of southcentral Alaska. Modified from Payne (1955); Hackett (1976a).

In Hackett's (1977) siluple Bouguer gravity map of the scuthern Susitna lowland (E1g. 7), gravity highs correlate with exposures of pre-'Tertiary basement rocks, and gravicy Lows indicate areas underlain by Tertiary sediments. Relief on the pre-Tertiary basement surface generates the larger anomalies 


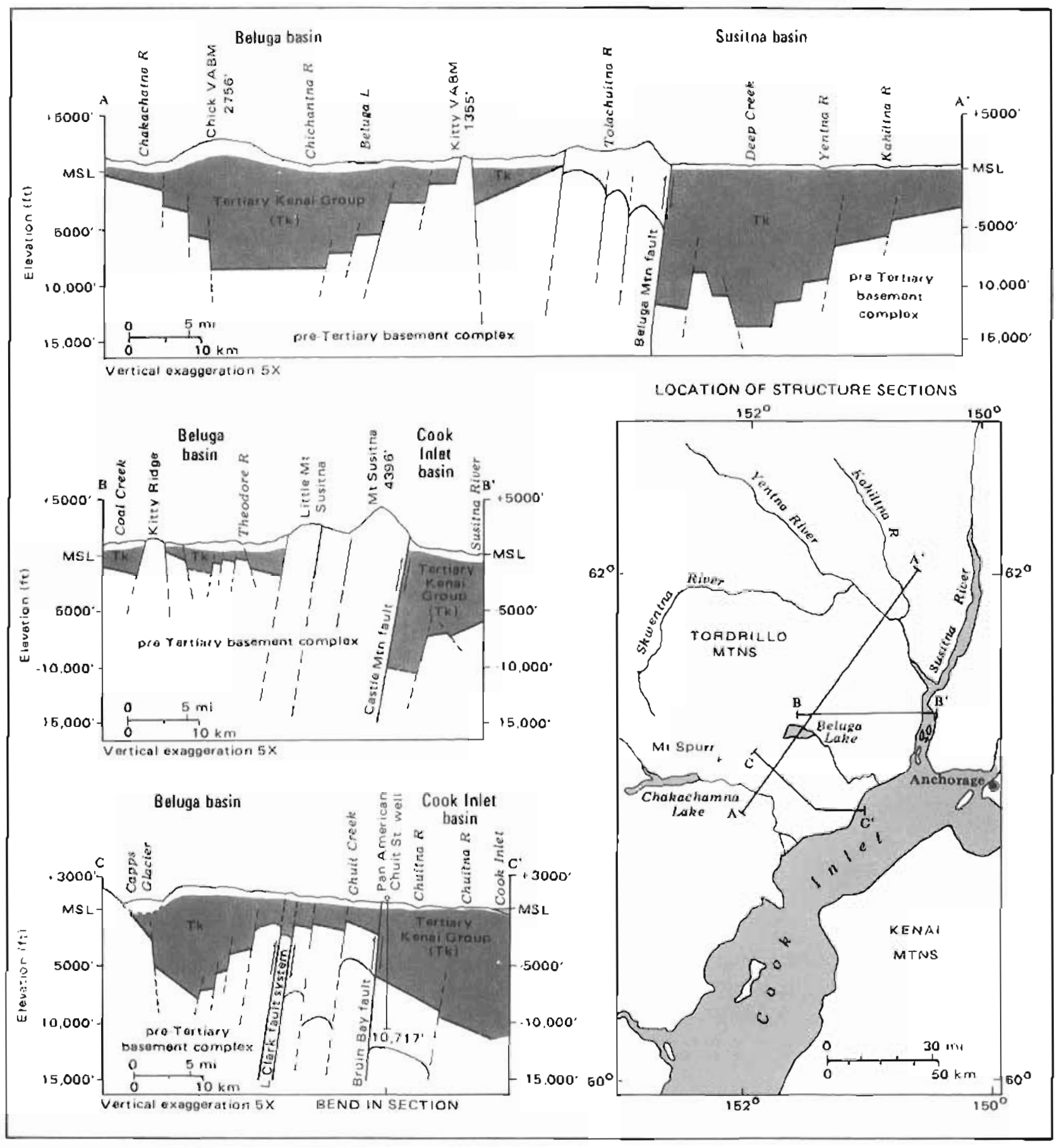

Figure 5. Structure sectjons based on geophysical proltles iacross the Bcluga basin and adjacent areas. From Hackett (1977).

over the lowland. The Beluga, Susitna, and Yentna basins are characterized by steep gravity gradients and low Bouguer anomalies which indicate the presence of large basenent discontjnuities where deep tectonic basins form. The regional gravily gradient over the upper Cook Inlet region infers a gradual westward thickening of che earth's crust (Barnes, 1966; Hackett, 1977). The Castle Mountain fault bends or splays into the Bruin bay fault zone south of the lake 


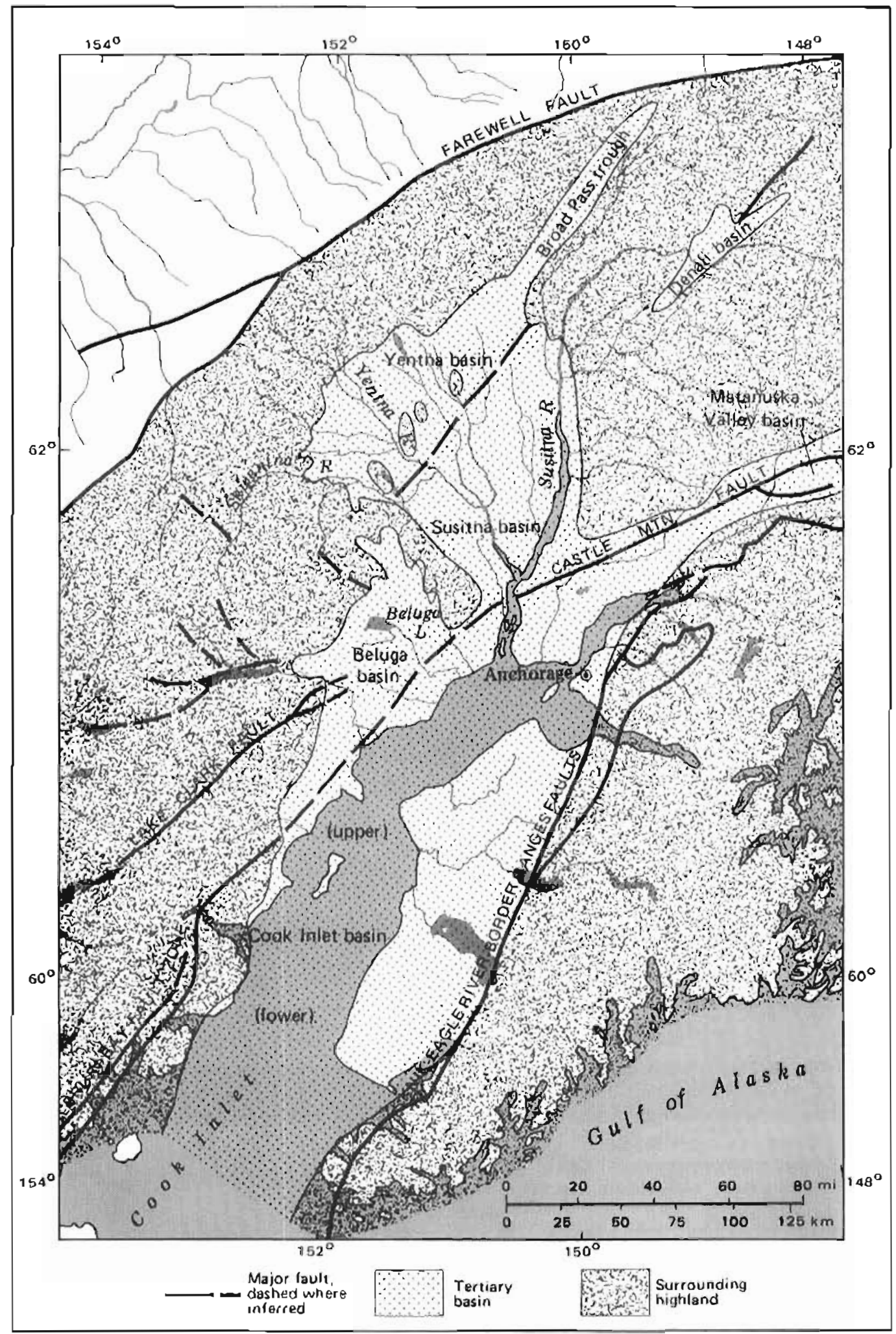

Figure 6. Major Tertiary basins of the Cook Inlet-Susitna lowland. From Hackett (1977). 


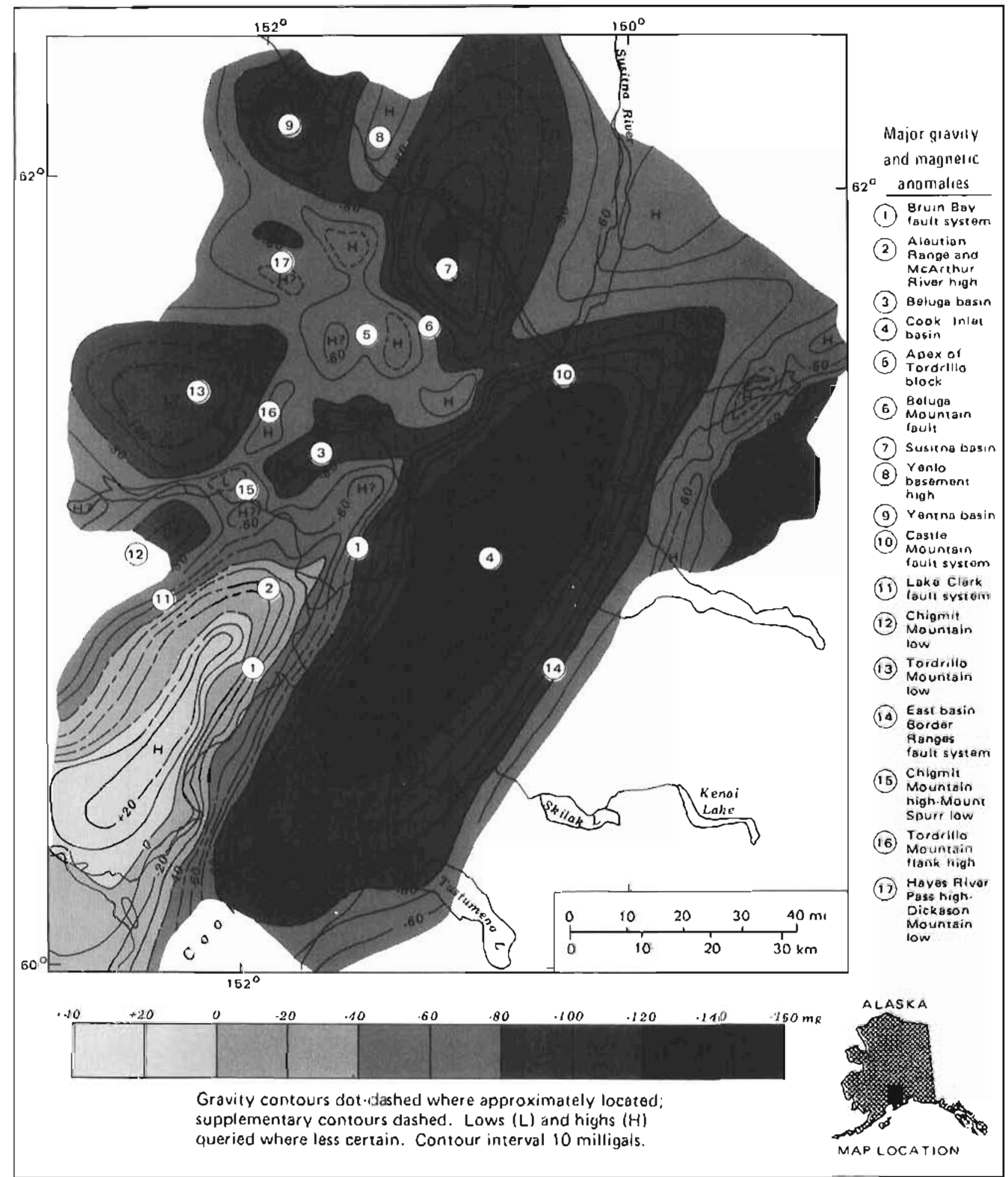

Figure 7. Simple Bouguer gravity map of the Beluga basin and adjacent area. From Hackett (1977).

Clark Eault (fig. 8); it is thought not to continue west-southwest into the Lake clark Eault as originally inferred. The Beluga Mountain fault trends northwest along the Beluga Mountain-Mount Susitna front and Susitna lowland 


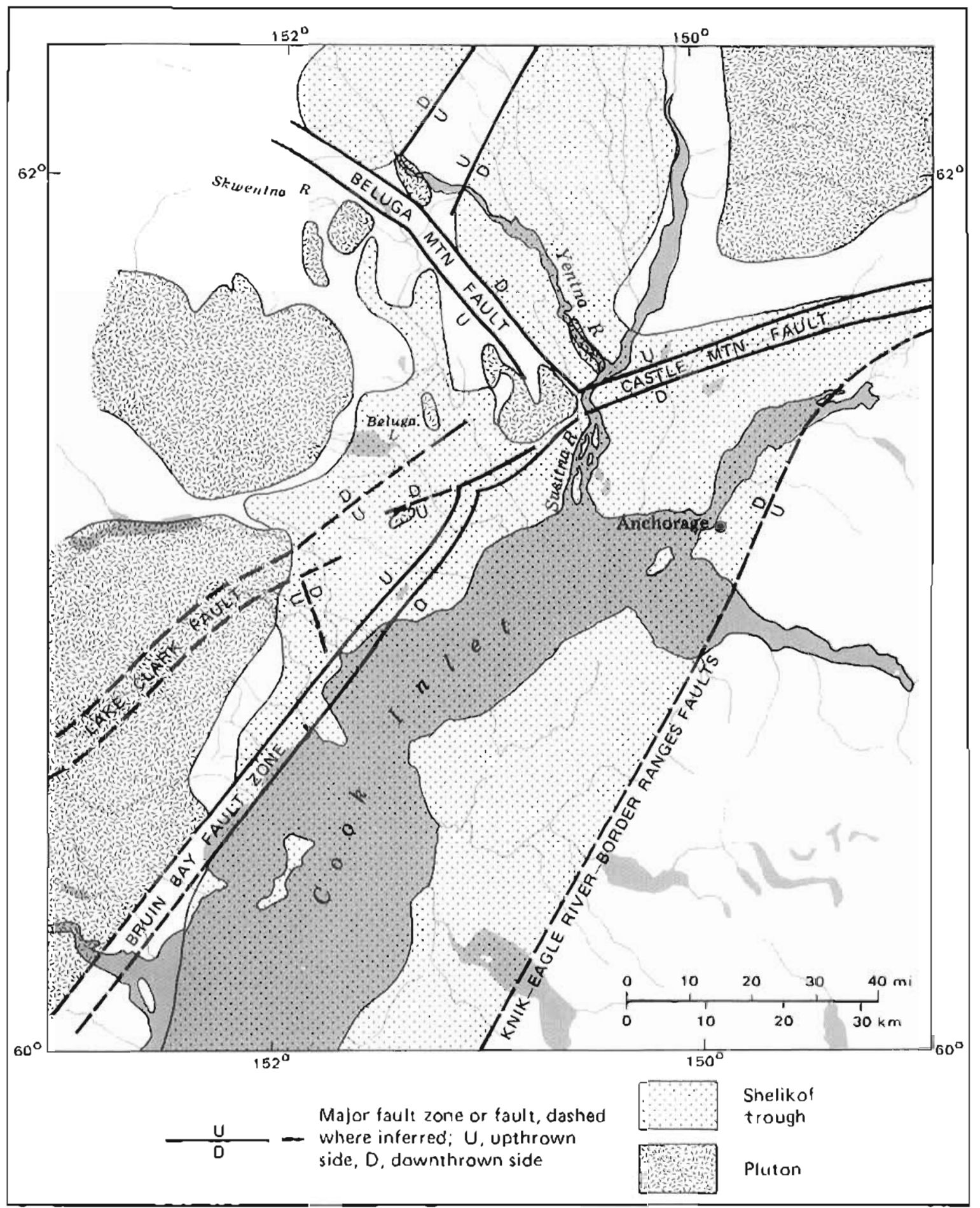

Figure 8. Major fault systcors in the Shelikof lruugh wich basin outlines. Modificu From Hacket: (1976b).

boundary; Hackect (1977) interpreted it as a high-angle, $60^{\circ}$ - to $75^{\circ}$-dipping, reverse fault upthrown on the southwest, with a vertical displacement of over $3,000 \mathrm{~m}$. The Castle Mouncain Eault, clearly visible as a surface lineanient crossing tise Susitna Flats (Kirschner and Lyon, 1973), displays dextral strikeslip movement or right-lateral drag, as evidenced by offset strean irainages. 


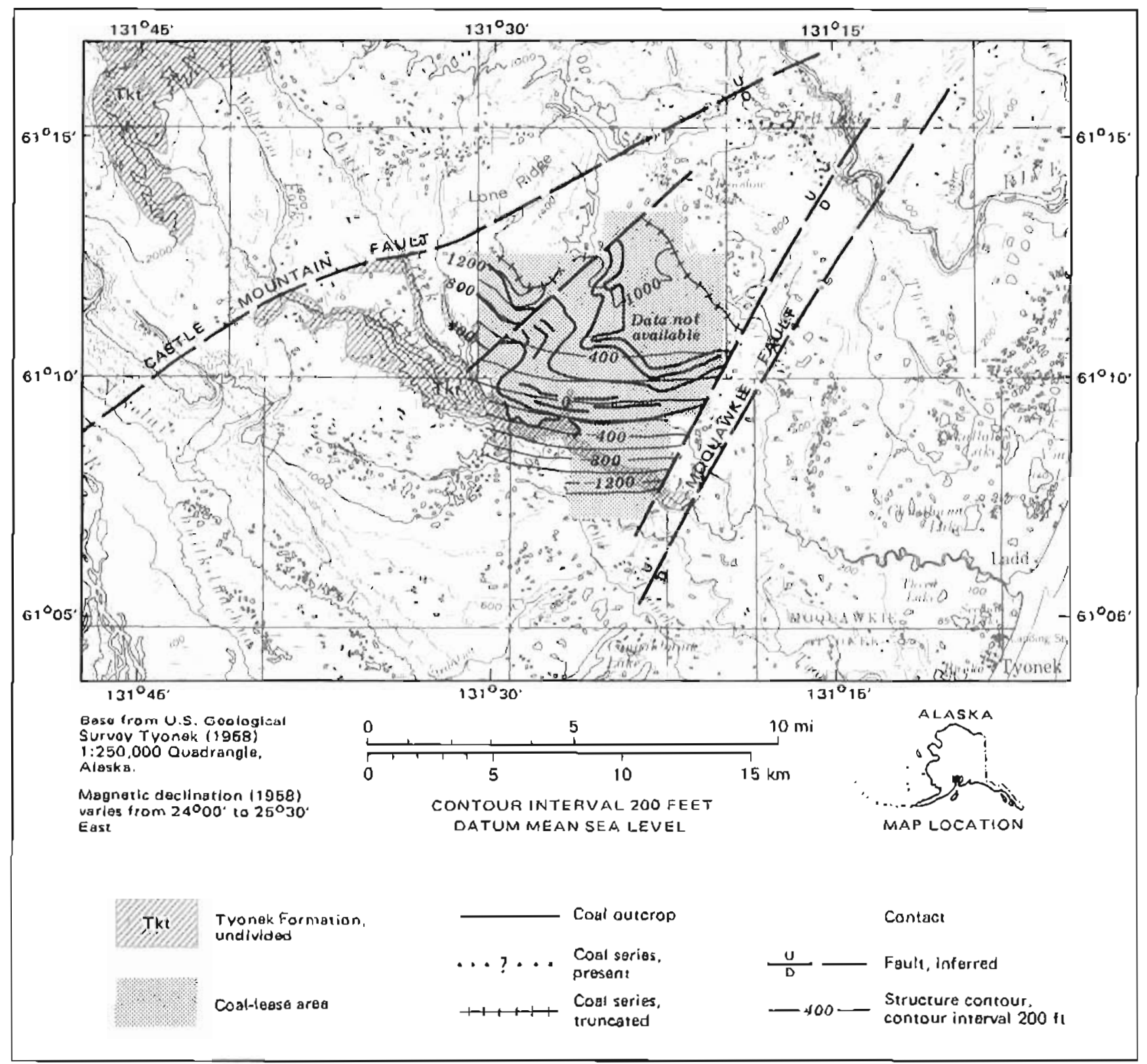

Figure 9. Structure contours, coal outcrops, and coal lease areas, Chultna district, southern Susitna lowland. Modified from kamsey (1981b).

These major high-angle rcverse faults and small-scale, high-argle block Eaults within the Susitna lowland definitely offset the coal deposits. Most stratigraphic studies of the Cock Inlet petroleum province end at the Castle Mountaln Eault; however, important coal leases in the Beluga basin lie on both sides of the fault zone. The Impact of such faulting on mine development can vary; upthrown blocks, such ns in the Chuitna district, provide favorable conditions for extraction of coal (iig. 9), whereas downthrown blocks localize channeling, which leads to erosion of coal seams.

A major structural discontinuity (Eig. 10) consisting of the Bruin Bay Eault, the Moquawkie magnetic contact, and that part of the Castle Mouncain fault east of the Theodore River, divides the Susitua lowland 1nto a deeper southeastern segment, which subsided more rapidly during accumulation of the 


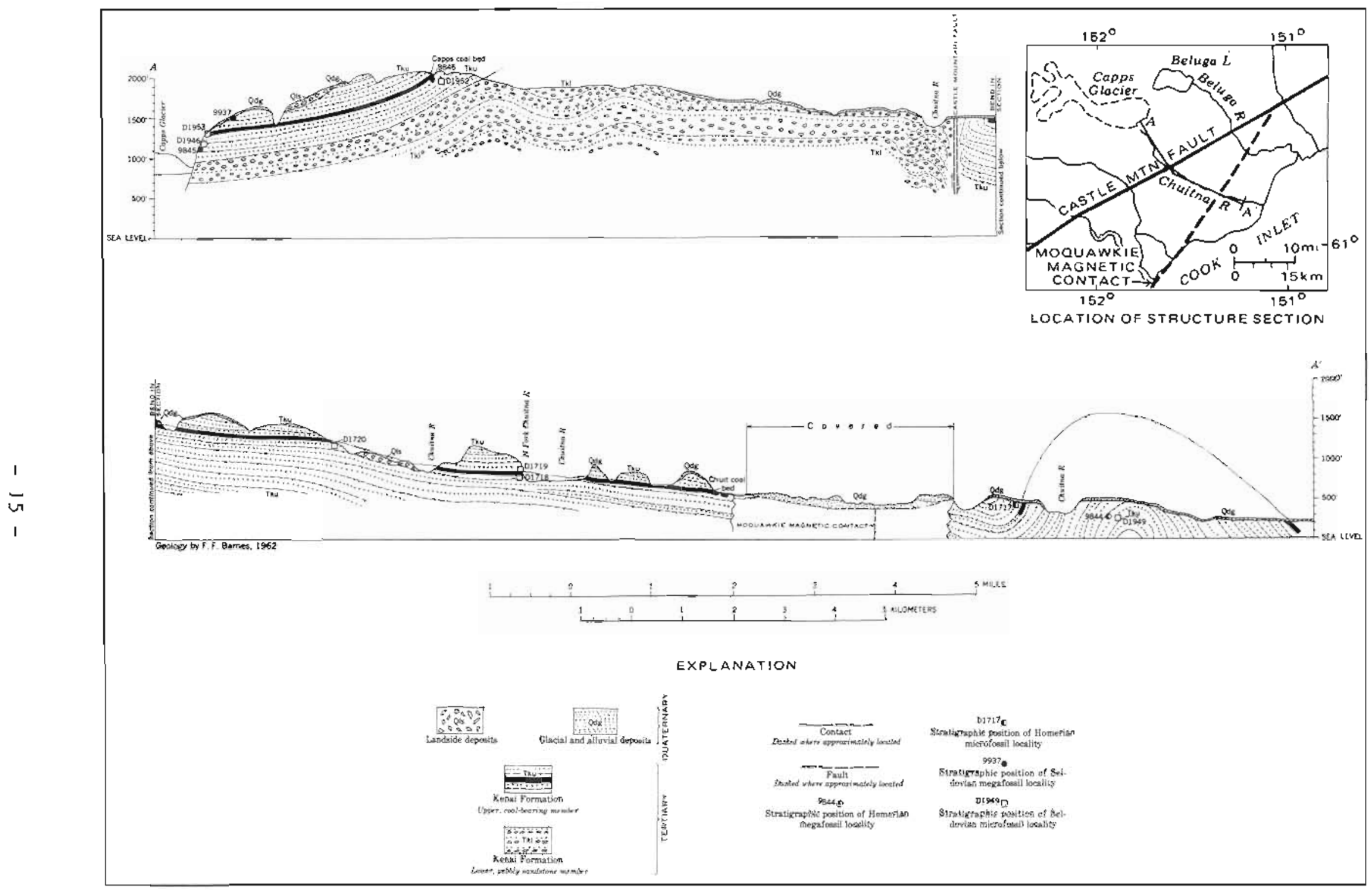

I'igure 10. Structure section between Capps Glacier and the lower Chuitna River. From wolfe and others (1966). 
Kenal Group, and a shallower northwestern segment. North of Castle Mountain fault, the Kenal Group is typically $<600 \mathrm{~m}$ thick, whereas in the southern Susttna lowland it 1 s commonly as thick as 3,000 m (Grantz and others, 1963b; Wolfe and others, 1966; Calderwood and Fackler, 1972; Hartman and others, 1972). Figure 11 shows three generalized cross sections from western Susitna lowland areas. Major faults of the Cook Inlet region have controlled development and configuration of basin depocenters; these thick sedimentary sequences may also contain potential oll-and-gas resources (Hackett, 1976b; f1g. 12).

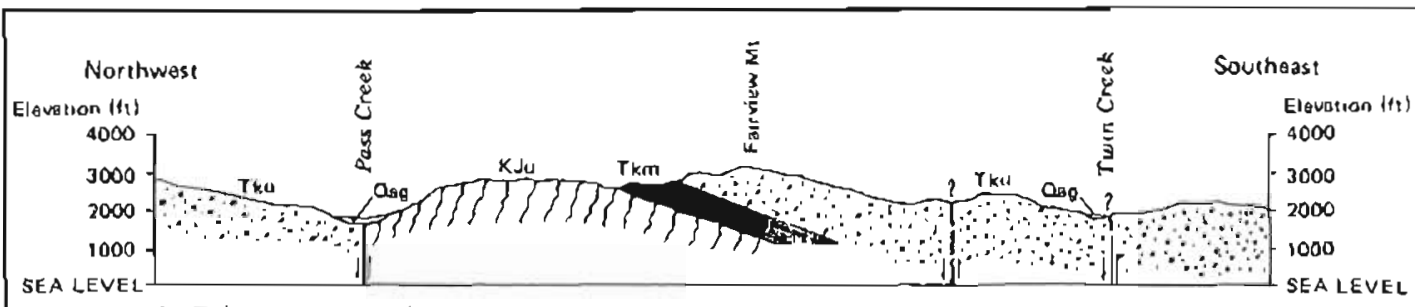

A. Fairvew Mountain arca

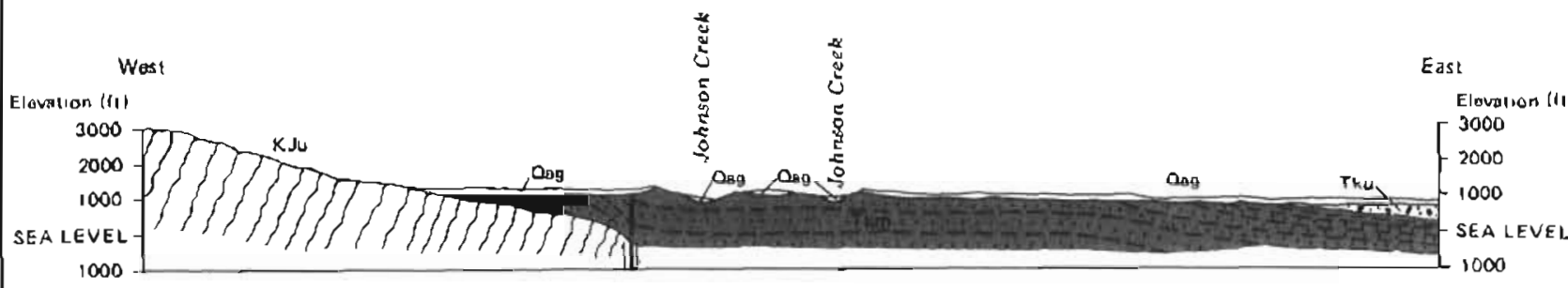

3. Johnson Creek area

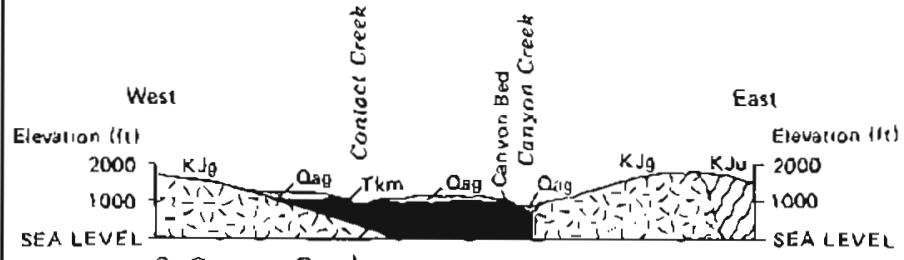

C. Callyon Creck area
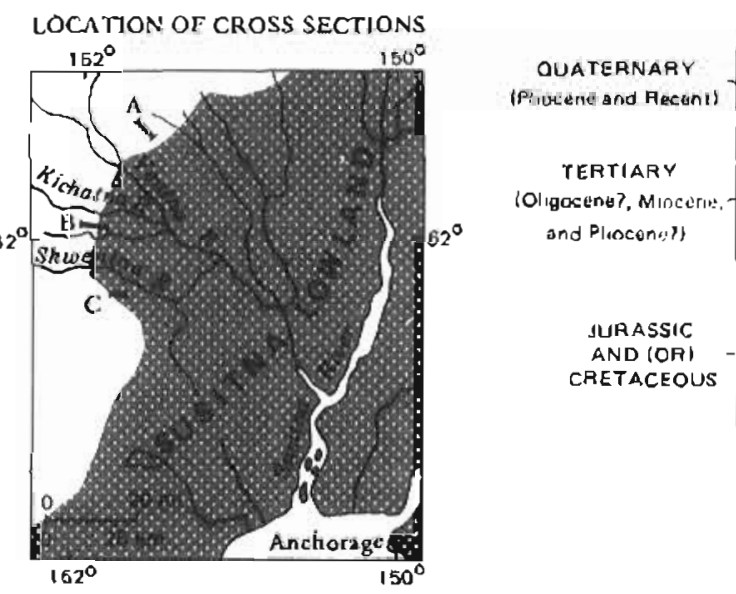

EXPLANATION

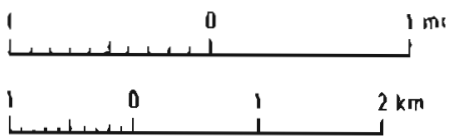

Uncomolidated deposils: indudes stream deposith, slaciw Lill, out wash gaved, coll uvium, and small areas of landellide dalsris $\because \because \because$ Konaj Fomalion, upper nember: poorly consolidnted pebbly audstomo and conslomerate

Kenaj Formation, lower member, interbedded sandshome, siltatone, dayatone, arul coil

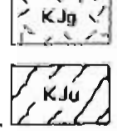

Cranilite intrusive roctes

Undifferenthited metsedimentrry rocks; mainly interbedded whate and prayuncke; may ind ude some volcanic and intrusive rociss

- - Contact, daghod where spproximately localed

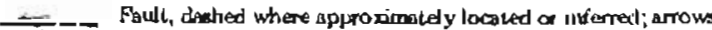
indicole direction of mevernant

Figure 11. Generalized geologic cross sections of areas along western margin (Falrview Mountain, Johnson Creek, and Canyon Creek) of Susitna lowlands. From Barnes (1966). 


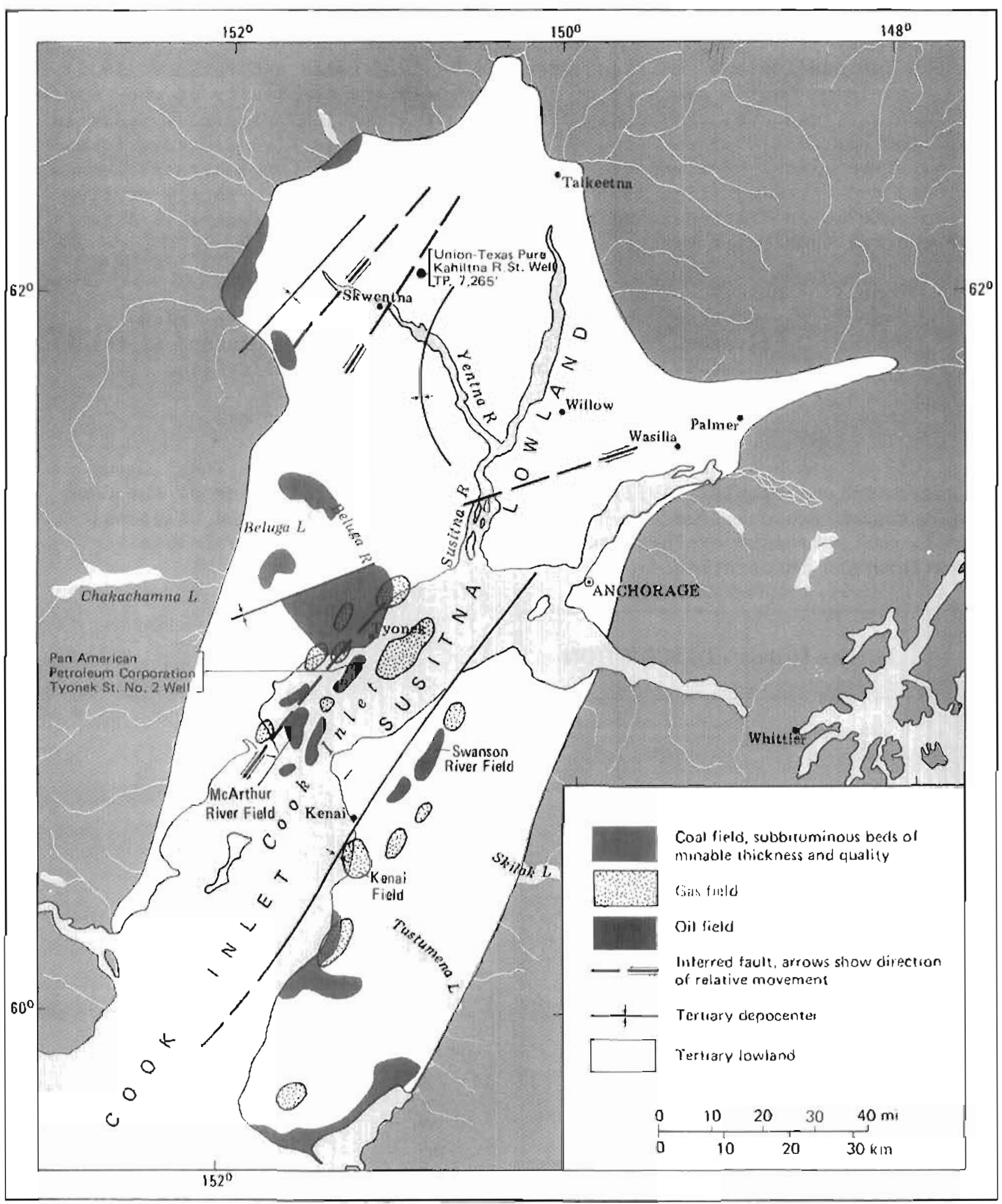

Figure 12. Tertiary depocenters and oil, gits, and coalfields in the Cook Inlet-Susitna lowland area. Modified from Hackett (1976b). 


\section{TERTIARY LITHOSTRATIGRAPHY}

Current stratigraphic nomenclature for the Tertiary coal-bearing strata of the Sustena lowland was first proposed by Calderwood and Fackler (1972) for the Cook Inlet basin. Because of the thickness and complexity of the Tertiary sedimentary sequence, they changed the 'Kenal Formation' originally adopted by Dall and Harris (1892) to 'Kenai Group' and recognized five distinct formations, from oldest to youngest: West Foreland, Hemlock Conglomerate, Tyonek, Beluga, and Sterling (fig. 13). Their divisions were based partly on five lithologic zones distinguished by Kelly (1963) from subsurface-well data in the central cook Inlet basin:

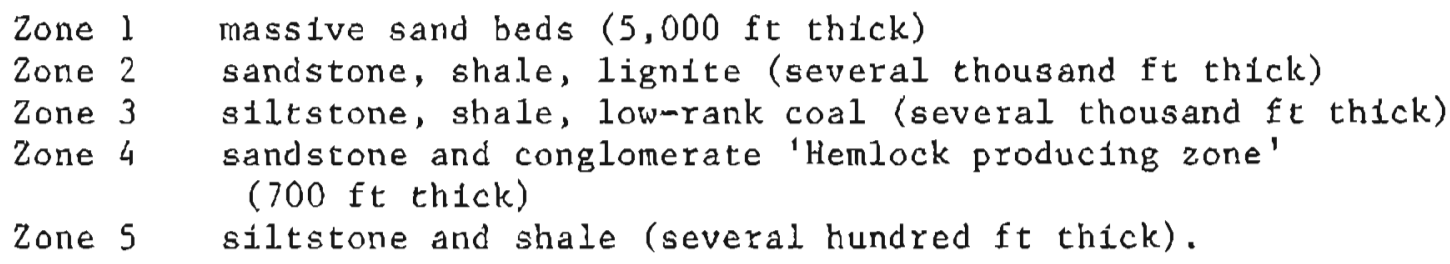

011 or gas has been produced from al1 formations of the Kenai Group (Calderwood and Fackler, 1972), although most major oll fields of the Cook Inlet region produce from the Hemlock Conglomerate (Magoon and Claypool, 1981), and petroleum exploration in this region has yielded valuable stratigraphic information.

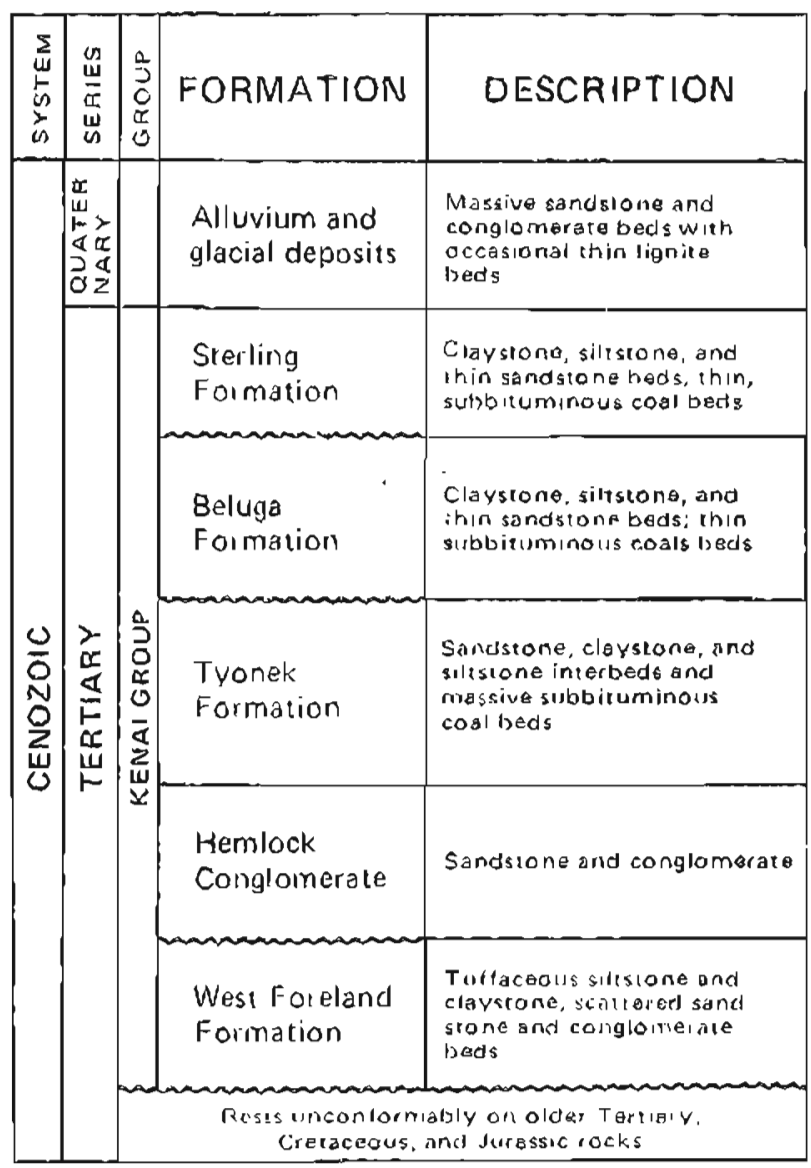

Figure 13. General stratigraphic nomenclature for the Tertiary Kenai Group of southcentral Alaska. From Calderwood and Fackler (1972). 
Magoon and others (1976) and Boss and ochers (1978) segregated the West Foreland lormation from the Kenai Group because of the major unconformity separating it from the overlying Hemlock Conglomerate. They regard the Hemlock Conglomerate, not the kest Foreland Formation, as the basal formation of the Kenai Group. Boss and others (1978) considered the Hemlock Conglomerate to be a member of the Tyontk Formation; Magoon and others (1976) included it with the Tyonek Formation in the1r. regional compilation (Sclumoll and others, 1981).

Barnes (1966) divjded the 'Kenai Formation' into lower, middle, and upper members; his coal-bearling middle member contains sandstone, silcscone, claystone, and conglomerate, and the enclosing upper and lower stratigraphic units consist predomirantly of pebbly sandstone ano conglomerate. Magoon and others (1976) and Reed and Nelson (1980) tentatively correlated equivalent formations betwecn their 'Kenal Group' and the 'Kenai Formation,' basing their work on paleobotanical and palynological scudies of Wolfe and others (1966) and on the stracjgraphic studies of Calderwood and Fackler (1972). In table 1 Barnes's correlations are compared vith those of Magoon and others and Recd and Nelson.

The Kerlat lixoup represents clastic fore-arc-basin deposits of early and late Cenozoic tectonic cycles (Fisher and Magoon, 197\%; Schinol 1 and othexs, 1981). The rocks are charactelistic of a continental fluvial system: they cre nondeltaic, except for local lacustrine cieltas, and appear to be products of a meandering fluvial regime (particulariy in the Tyonek Formation). Lateral. migration produced fining-upward sequences, and rapid lateral and vertical changes in lithology are common. Chamnel deposits are characteristically coarse-grained seaiment; fine-graincd rooted siltstone, shale, and thin coal represent interfluve sediments. Levees that flank channels are typjeally fine-gralner sandstone ano siltstone. Sedimentary structures other than cross-stratification in coarsel grained units are rare on natural exposures.

The coals and enclosing strata of the Susitna lowland also are characteristic of Ereshwater paleoenviroments. These sedimentary sequences can be differentiated from marine and brackish-water systems by the following primary characteristics:

- moderate to high ash content in coals-represents influxes of terrigenous sile (ash typicaldy low in pyrite and carbonate mirierals and high in quarta and kaolinite)

- locally thick coals, but discontinuous laterally

- Low sulfur in coals and overburden

- lack of diagnostic marine fossils-absence of faunal elements and burrowing (biogenic structures; bioturbation)

- high sand-to-tiud ratios of associated rocks

- aburldant organic matter and plant detrifus of associated rocks; common coalified roots and in-piace stumps

- rare dark-gray to black claystone

- frequent rooted, slickensicied, refractory underclaysi

- illj.tic-kacilinitic clay assoclations

- siderite rodules aud bands present in coals and assoclated strata, bit not common or diagnostic--presence reflects poor drainage.

Tertiary sedimencary rocks of the susitna lowland rotith of the Castle Mouncair fault are relattvely thin-m typically 600 in or less, but with three depocenters over $1,500 \mathrm{~m}$ thick (fig, lit)--and they nonconformably overile 
Table 1. Tentative correlations of geologic units.

Area

1. South of Capps Glacier

2. North of Lone Ridge

3. Beluga River

a. North of Lake Clark fault

b. Between Lake Clark and Bruin Bay faults

c. South of Bruin Bay fault

4. Chuitma River between Lake Clark and Bruin Bay faults

5. Tributaries of Nikolai Creek south of Lake Clark fault

6. Threemile River-Lewis River area south of Little Mit.

Susitna and norti of Lake Clark fault

7. Drill Creek and Coal Creek

8. Talachulilna River; Friday and Salurday Creeks

9. Canyon Creek

10. Skwenina River norlheast of Porcupine Butte

11. Kahiltna River north of contluence with

Yentua River

Area

12. Johnson Creek

13. Kichatna River

14. Nakochna River

15. Yenlo Creek, Lake Creek, and Kahiltna River northwest of Shulin Lake

16. Beay Creek cast of Little Peter's Hills

17. Drainages southeast of Peters Hills

18. Cache Creek

19. Dollar Creek

20. Long Creek-Cottonwood Creek

21. Tributaries of Long CreekColtonwood Cieek norlliwest of Peters Hills and Willow, Poorman, Pass, and Divide Creeks

22. Treasure Creek east of Chelatna Lake

23. Fairview Mtn, and region south of ML. Kliston

24. Cottonwood Creek

25. Sunflower Cieek

26. Blulf Creek, southwest margin of Ruth Glacier
Baines (1966):

Kenai Formation Member

Tyonek Quadrangle

$\begin{array}{ll}\begin{array}{l}\text { a. Lower } \\ \text { b. Middle } \\ \text { Lower }\end{array} & \begin{array}{l}\text { a. West Foreland } \\ \text { b. Tyonek } \\ \text { West Foreland }\end{array} \\ \begin{array}{ll}\text { a. Lower } \\ \text { b. Middle }\end{array} & \begin{array}{l}\text { a. West Foreland } \\ \text { b. Tyonek }\end{array} \\ \begin{array}{ll}\text { c. Middle } \\ \text { Middle }\end{array} & \begin{array}{l}\text { c. Beluga } \\ \text { Tyonek }\end{array} \\ \text { Lower } & \text { Tyonek } \\ \text { Lower } & \text { West Forcland }\end{array}$

Middle Tyonek

Midile Tyonek

Middle Tyonek

Middle Tyonek

Middle 'Tyonek

Barnes (1866): . Kenai Formation Member

Talkeetna Quadrangle
a. Middle
b. Upper
Upper
a. Middle
b. Upper
Middle

Middle

Middle

Middle

Middle

Middle

Upper

Upyer

Sterling

Upper

Sterling

Middle

Middle

Upper

b. Sterling Sterling

b. Starling

Sterling

Sterling

Sterling

Sterling

Sterling
Magoon and others (1976):

Kenai Group Formation

Reed and Nelson (1980):

ISenai Group Formation

a. Sandstone Member of Tyonek

Sandstone Member of Tyonek or

a. Conglomerate Member of Tyonek

Sandstone Member of Tyonek

Sandstone Member of Tyonek

Sandslone Member of Tyonek

Sandstone Member of Tyonek or

Conglomerate Member of Tyonek

Conglomerate Membey of Tyonek or Sterling 


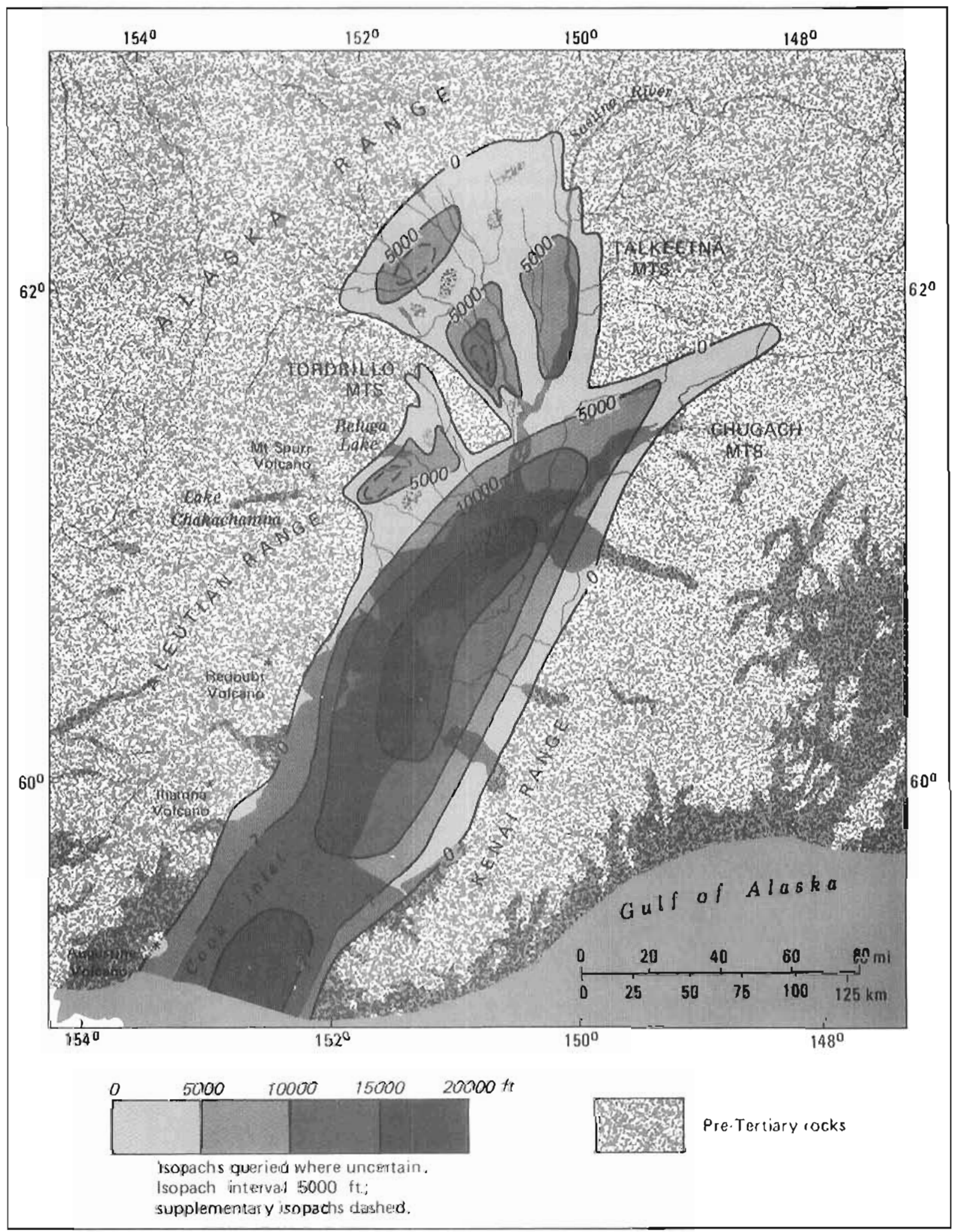

Figure 14. Ceneralized isopach map of Tertiary depostes in the Cook InletSusitna lowland area. Modified from Kirschner and Lyon (1973). Hartman and others (1972), and Hackett (1977). 
grantic rocks. The Kerial Group ranges to over 3,000 m thick, but is commonly $<1.500 \mathrm{~m}$ thick south of the Castle Mountain fault in the southern Susitna lowland; in this region, it usually overlies older Tertiary and Mesozoic sedimentary rocks. In the central lialt of the Conk Inler basin, the group is more than 4,500 m thick (Kirschnor and Lyon, 1973; Hartoran and others, 1974).

Kenai Group sediments in the Susicna Jowland derived mainly from plutonic and metamorphic sources in the cectorically active Alaska Range and Talkeetna Mountains. Kirschner and lyon's (1973) nodel porrays a broad intermontane trough confined by burderlands of low to moderate relief during walmı to temperate climatic conditions (EIg. 15). They dividc deposition of the Kenai Group of the Cook lnlet basir. into three phises based on the lithologic and mineralogic character of the sedjments: (1) an Oligocene-Mlocelle transgressive phase; (2) a biief late Miocene culmuration (stillstand); and (3) a Pllocere regressive phase. The West Foreland Formation, Hemlock Conglomerate, and lower Tyorek Formation were deposited in the cransgressive phase. The late Níccene culmination was characterized by a transitional period of low-conergy sedimentation, when the siltstone, carbonaceous shale, and coal in the upper part of the

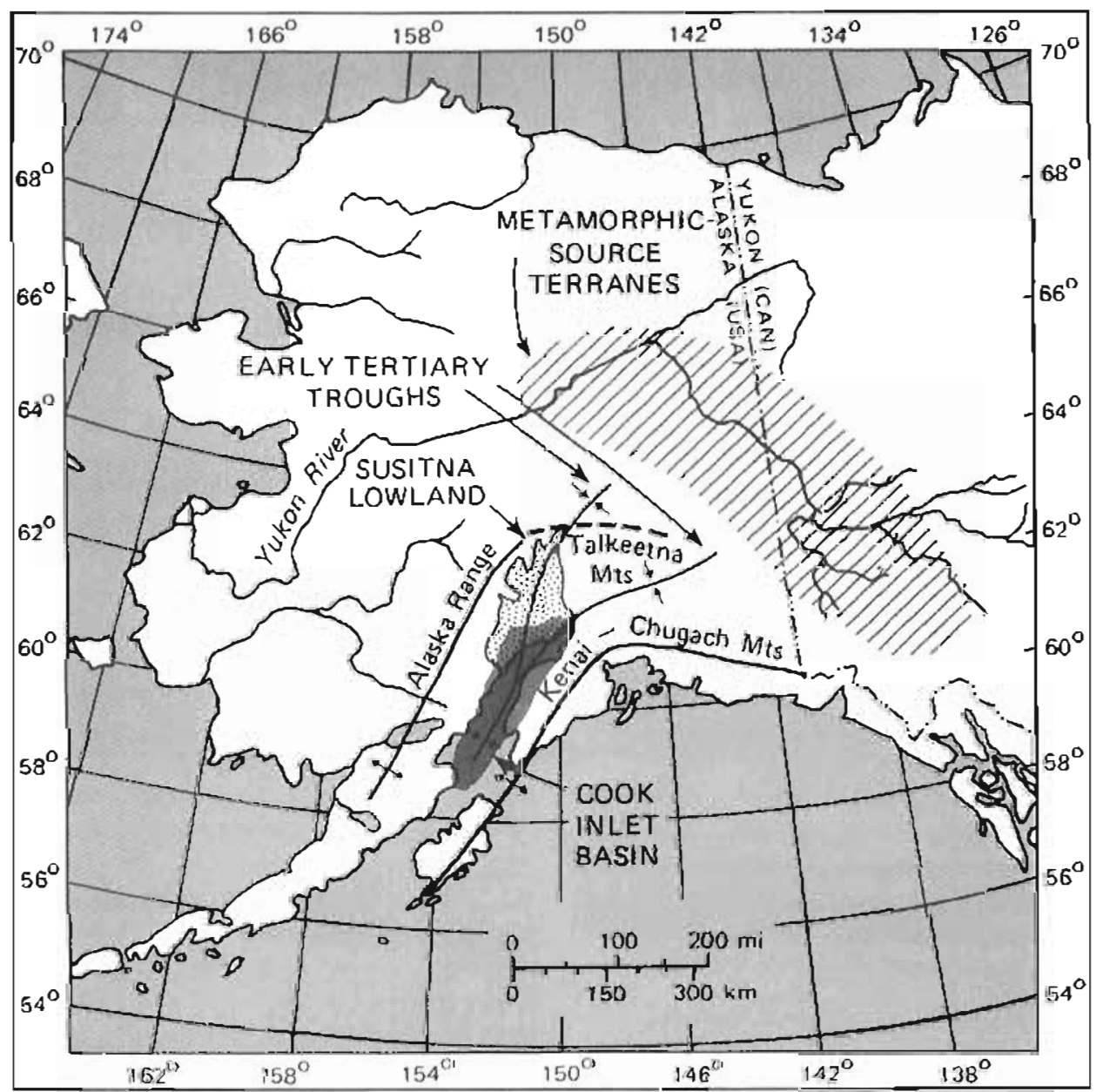

Figure 15. Primary elements of a Tertiary riodel for the Cook rnlet-Susttna lowland. Fron Kirschnet and tyon (1973). 
Tyonek Formation anc the lower part of the Beluga formation were depostted. All factors telated to ccal formation, such as plant growth, basin subsidence, sediment supply, compaction, and interaction of the ground-water table, must have been favolable at that ctme. The upper part of the Beluga Formation and the Sterling Formalion were deposited during the Pliocenc regressive phase.

Exposures of the Kenai Group are confined to the basin rim (foothilds of the Alaska Range) and isolated, usually steep walls of incisec and largely inaccessible stream canyons in the lowlands. Minor outcrops of Tertiary rock also cccur along coastal areas such as Beshta Bay (fig. 16). Tertary deposits are usually overlain by Pleistocene glacial drift or stream alluvium that veils the underlying material. The contact between Tertiary anc Guaternary deposits is often obscured hy deep weallering or buried. Outcrops of coalbearing deposits are widely distributed but discontinuous and highly weatlered (sheet 1 and app. $\Lambda$, cables A-l through A-3); spatial relationships are therefore difeicult to observe. Without essential suhsurface control, horizontal migration of Individual facies cannot be documented.

Logs are available from several oil wells in the southein Susitna lowland near Cook Inlet: (Magoon and orhers, 1976), and, in the cencral Susitna lowland a Union-Texas Petroleuni well (Pure Kalilttna kiver State l) has been dillled. Two drill holes penetrate coal-bearing units in the Capps district (Chleborad and others, 1980, 1982). Core data from several USBM drill holes in the Eeluga field (Warfield, 1962) and the gravity data of Hackett (197i) on the southein Susitna lowland constitute the remaining availabje subsurface data.

In addition tu the Kenai Group, Eive Tertiary or Cretaceous sedimentary formations crop out in the southcastern part of the Susitria lowland (sheet 1; Lable 2). These formatious are older than those of the Kenat Group (fig. 17), except for the Tsadaki Formation, which is approximately time equivalent to

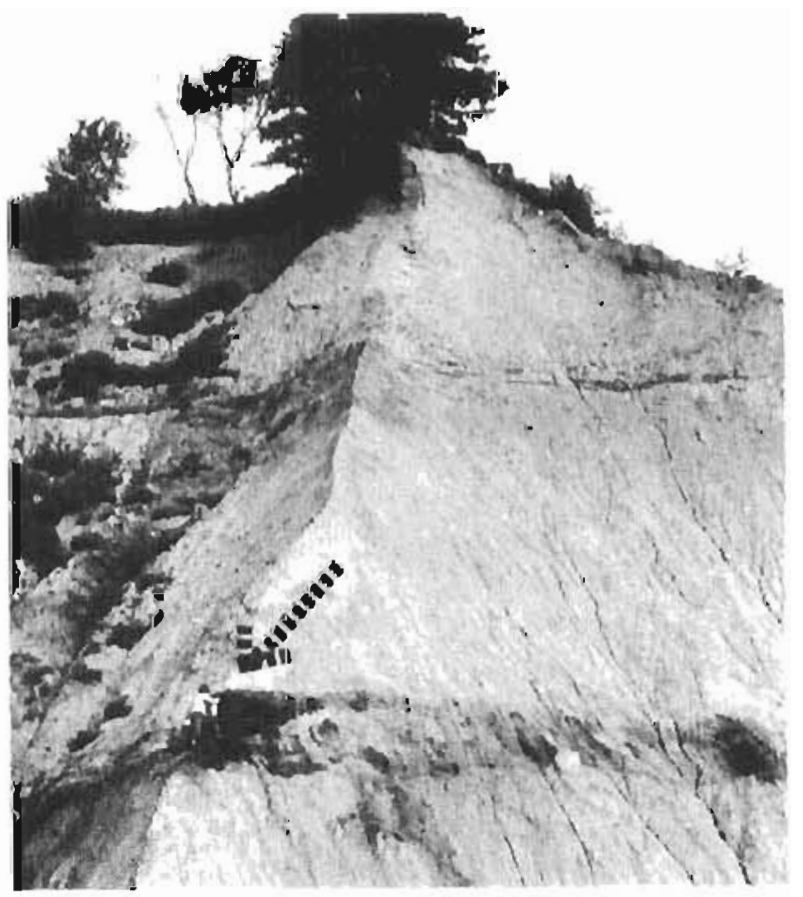

Figure 16. Coal-bearing Tertiery sedimentary rocks (Beluga Formation) exposed along a $15-\mathrm{km}$ outcrop at Beshta Bay, Cook Inlec. Photograph by J.E. Sperber, 1981. 
Table 2. Summary of chief characteristics of Tertiary and Cretaceous sedimentary rock formations of the Little Susitna district (southeastern Susitna Lowland) and lower Matanuska Valley (modified from Clardy, 1978).

\begin{tabular}{|c|c|c|c|c|c|}
\hline Formation & Age & Thickness & Lithology & $\begin{array}{l}\text { Stratigraphic } \\
\text { relationship }\end{array}$ & $\begin{array}{l}\text { Depositional } \\
\text { environmenl }\end{array}$ \\
\hline Tsadaka & $\begin{array}{l}\text { Oligocene; } \\
\text { time equiva- } \\
\text { lent of low- } \\
\text { est beds of } \\
\text { Kenai Group }\end{array}$ & $\begin{array}{l}\text { Over } 150 \mathrm{~m} \text { in } \\
\text { Tsadaka Canyon }\end{array}$ & $\begin{array}{l}\text { Crudely stratified, massive } \\
\text { conglomerate; marginal } \\
\text { conglomeratic facies of } \\
\text { Kenai Group }\end{array}$ & $\begin{array}{l}\text { Overlies Wishbone and } \\
\text { Chickaloon Formations } \\
\text { with a distinct angular } \\
\text { unconformity in lower } \\
\text { Matanuska Valley }\end{array}$ & $\begin{array}{l}\text { Sheet-flood debris } \\
\text { deposited on allu- } \\
\text { vial fans }\end{array}$ \\
\hline Wishbone & Eocene & $550-600 \mathrm{~m}$ & $\begin{array}{l}\text { Well-Jithified conglom- } \\
\text { erates, sandstones, and } \\
\text { siltstones }\end{array}$ & $\begin{array}{l}\text { Unconformably over- } \\
\text { lies Chickaloon Forma- } \\
\text { lion in Matanuska } \\
\text { Valley }\end{array}$ & $\begin{array}{l}\text { Fluvial environ- } \\
\text { ment; alluvial } \\
\text { fans and associated } \\
\text { braided streams, } \\
\text { perhaps meander- } \\
\text { ing stream deposits } \\
\text { in part }\end{array}$ \\
\hline Chickaloon & Paleocene & $\begin{array}{l}\text { At least } 1,500 \mathrm{~m} \\
\text { thick in } \\
\text { Matanuska } \\
\text { Valley }\end{array}$ & $\begin{array}{l}\text { Well-indurated clay- } \\
\text { stones, siltstones, } \\
\text { sandstones, conglom- } \\
\text { erates, coal }\end{array}$ & $\begin{array}{l}\text { Conformable with } \\
\text { overlying Wishbone } \\
\text { Formation south of } \\
\text { Willow Creek in } \\
\text { southwestern } \\
\text { Talketna Mountains }\end{array}$ & $\begin{array}{l}\text { Fluvial, braided to } \\
\text { meandering stream } \\
\text { environment in } \\
\text { lower part; fluvial } \\
\text { meandering to } \\
\text { paludal environ- } \\
\text { ment in upper part }\end{array}$ \\
\hline $\begin{array}{l}\text { Arkose } \\
\text { Ridge }\end{array}$ & Paleocene & Unknown & $\begin{array}{l}\text { Coarse-grained clastics } \\
\text { (arkosic conglomerates, } \\
\text { minor shales) }\end{array}$ & $\begin{array}{l}\text { Nonconformably over- } \\
\text { lies plutonic rocks } \\
\text { along south flank of } \\
\text { Talkeetna Mountains } \\
\text { and overlies Talkeetna } \\
\text { Formation to north- } \\
\text { east }\end{array}$ & $\begin{array}{l}\text { Local source, } \\
\text { fanglomerate de- } \\
\text { posit }\end{array}$ \\
\hline Matanuska & $\begin{array}{l}\text { Early to } \\
\text { Late Creta- } \\
\text { ceous } \\
\text { (Albian to } \\
\text { Maestrich- } \\
\text { lian). }\end{array}$ & $\begin{array}{l}\text { Over } 1,200 \mathrm{~m} \\
\text { thick at type } \\
\text { section in } \\
\text { Matanuska } \\
\text { Valley. }\end{array}$ & $\begin{array}{l}\text { Siltstones, sandstones, } \\
\text { and cobble conglom- } \\
\text { erates. }\end{array}$ & $\begin{array}{l}\text { Underlies Terliary } \\
\text { rocks with local dis- } \\
\text { conformity. }\end{array}$ & $\begin{array}{l}\text { Marine; sublit- } \\
\text { toral to outer } \\
\text { bathyal or abys- } \\
\text { sal deposition by } \\
\text { density currents or } \\
\text { submarine slumps. }\end{array}$ \\
\hline
\end{tabular}

the lowest beds of the Kenal Group. The ChIckaloon Formation is the only coal-hearing unit in this area.

\section{West Foreland Formation}

The West Foreland Formation crops out in the southern fcothills of the Alaska Range. In the Beluga field, exposures occur northwest of the Lake Clark and Castle Mountain faults. In the Capps district, Adkison and others (1975) measured $630 \mathrm{~m}$ of West Foreland Formation strata in exposed sections. The type section for the West Foreland Formation is a drill ho?e $60 \mathrm{~km}$ south of the Capps district; at the type locality, the unit is $270 \mathrm{~m}$ thlck (Ke11y, 1963).

The West Foreland Formation is the lone representative of the early Cenozolc tectontc cycle. It was deposited on an exosional surface of Mesozolc and early Textlary rocks and 1 s composed of interbedded siltstone, tuffaceous chaystone, graywacke, and poorly sorteo polymictic conglomerate with a few thin Iignitic coal beds (Schuoll and others, 1981). 


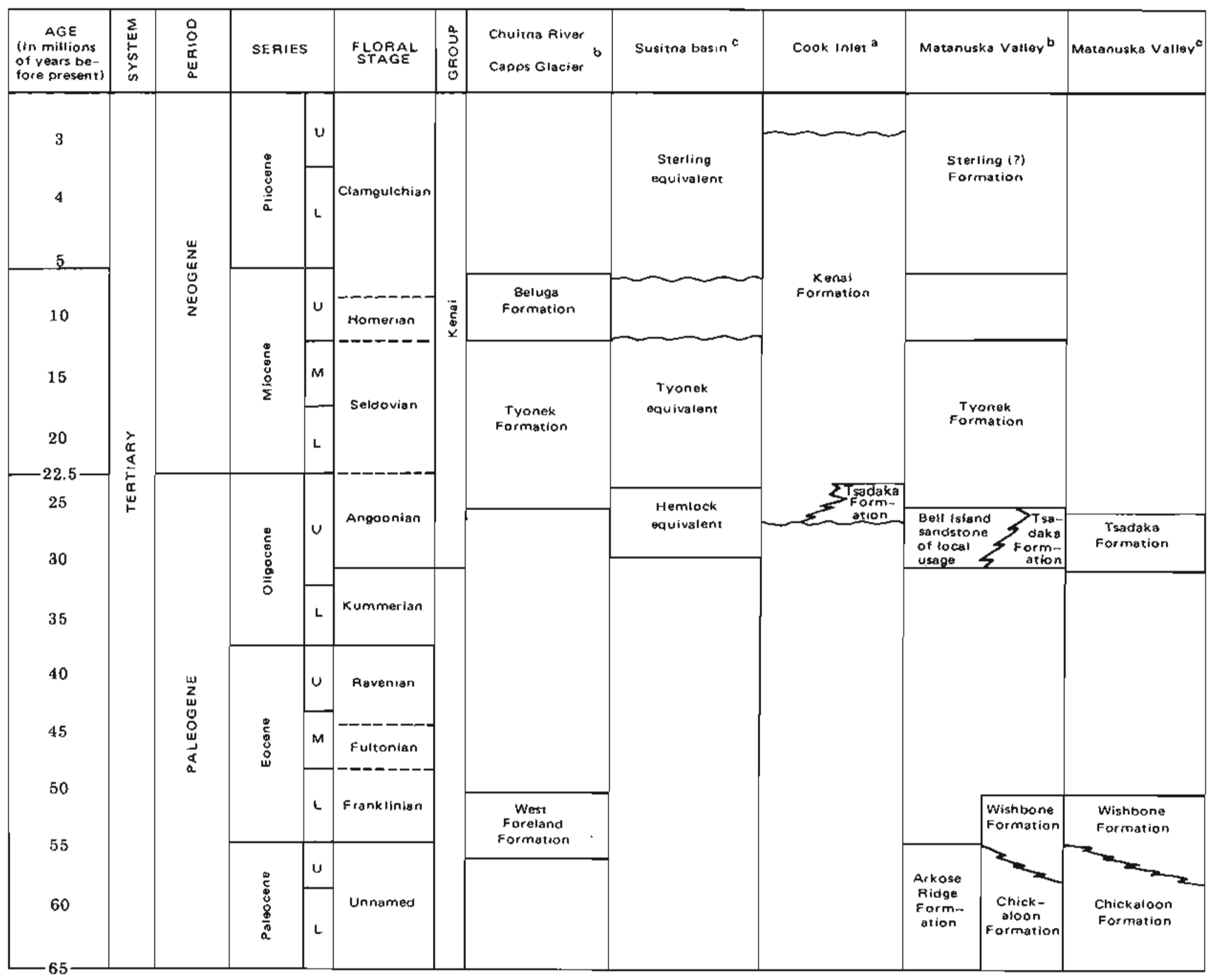

Figure 17. Surface and subsurface Tertiary stratigraphy of five coal-bearing regions in southcentral Alaska. From Wolfe and others $(1966)^{\mathrm{a}}$; Magoon and others (1976) ${ }^{\text {; }}$ Conwell and others (1982) ${ }^{\mathrm{c}}$. 


\section{Hemlock Conglomerate}

The Hemlock Conglomerate has been mapped northwest of the Castle Mountaln fault (Detterman and others, 1976b); Magoon and others (1976) restrict it to the southeast side of the Bruin Bay fault. Calderwood and Fackler (1972) found it in the subsurface in the Beluga area. The unit is predominantly pebbly sandstone and conglomerate with minor siltstone. The conglomerate contains white quartz and black chert clasts (Conwell and others, 1982). Thought to be early Oligocene and assigned to the Angoonian stage by Wolfe (1977), the Hemlock Conglomerate forms the basal unit of the late Cenozoic tectonic cycle in the reffaed classiffcation of the Kenal Group (Boss and others, 1978; Schmoll and others, 1981); the unit contains no significant coal deposits.

Tyonek Formation

The type section for the Tyonek Formation (Calderwood and Fackler, 1972; Sanders, 1981) is in the Pan American Petroleum Corporation Tyonek State 2 we11 which penetrated $2,272 \mathrm{~m}$ of Tyonek Formation and intersected 42 significantly thick coal beds (flg. 18). Adkison and others (1975) described exposures of the lower Tyonek Formation south of Capps Glacter, Including the Capps and Waterfa11 coal beds (flgs. 19 and 20), and assigned coal-bearing exposures along the Chuitna River to the upper part of the Tyonek Formation. The formation underlies most of the Beluga fleld southeast of the Lake Clark and Castle Mountain faults. Outcrops around Capps Glacter and along the Chuitna River serve as the type section for the Seldovian Stage (Wolfe and others, 1966; Wolfe, 1977).

The Tyonek Formation is generally finer grajned than the west Foreland Formation and Hemlock Conglomerate. The unit contains the thickest coal beds of the Kenat Group. Other lithologies present are massively bedded sandstone, siltstone, claystone, and conglomerate. Adkison and others (1975) divided the Tyonek Formation in the Chuitna district into a basal conglomerate, the Middle Ground Shoals Member, and a flner gralned upper coal-bearing unit, the Chuitna Member, whlch corresponds to the upper part of the lower Kenai Formation of Barnes (1966). In the Pan American Petroleum Chultna River State 1 we11, the Middle Ground Shoals Member occuples the interval from 562 to 1,894 m (Ramsey, 1981b). Adkison and others (1975) noted the absence of the Hemlock Conglomerate and the West Foreland Formation in the Pan American well, and stated that the Middle Ground Shoals Member rested on the Chickaloon Formation.

The Chuitna Member of the Tyonek Formation crops out in Chuitns River Canyon (fig. 2l) and correlates with the Kenai Formation of Barnes (1966). The Chuitna Menber comprises about the upper $565 \mathrm{~m}$ in the Pan American well. The stratigraphically highest coal bed in the we11, the Brown Seam (Ramsey, 1981b), probably corresponds to the Chuitna bed of Barnes (1966) and is underlain by five other beds (from highest to lowest): the Yellow, Green, Blue, Orange, and Red seams.

Reed and Nelson (1980) divided the Tyonek Formation th the Talkeetna Quadrangle Into the Sandstone and Conglomerate Members. The Sandstone Member efther is conformable with or interfingers with the underlying Conglomerate Member. The Tyonek Formation is separated from Mesozoic rocks by an angular unconformity. The Sterling Formation, stratigraphically the highest unit of 


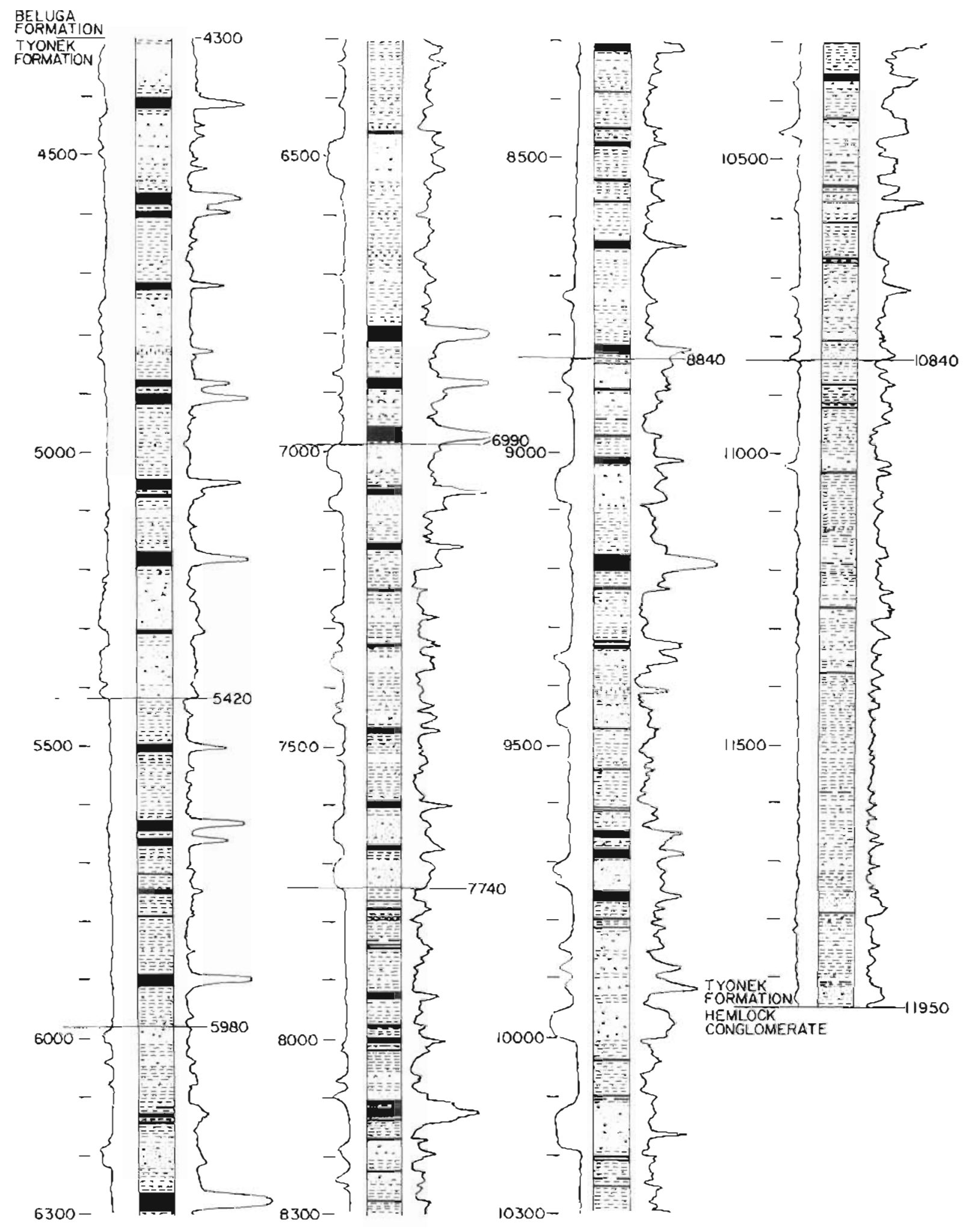

Figure 18. Lithologic and geophysical logs of the type section of the Tyonek Formation (Pan American Petroleum Corporation Tyonek State 2 well east of Granize Polnt, Cook Inlet). Prom Calderwood and Packler (1972). 


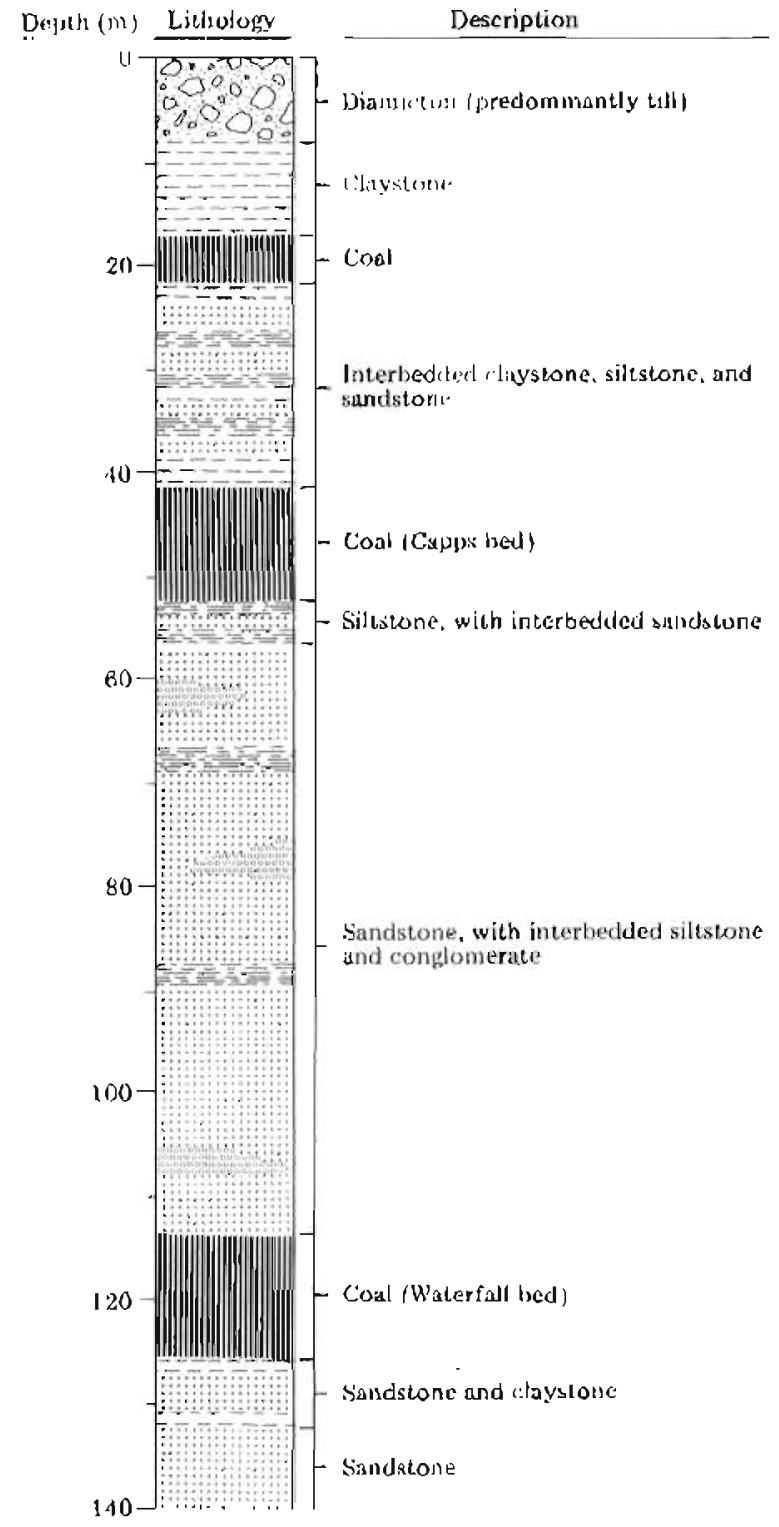

Figure 19. Generalized 11thologic log from a test hole near Capps Glacier showing stratigraphic positions of the Capps and Waterfall coal beds (Tyonek Formation). From Chleborad and others (1980).

the Kenai Group, unconformably overlies the Tyonek Formation, as suggested by the presence within it of coal fragments derlved from the Tyonek Formation. The beds of the Sandstone and Conglomerate Members consistently dip gencly or moderately to the southeast.

The Sandstone Member is dominantly (to 80 percent) sandstone, typlcally medtum to coarse gralned, pebbly, and poorly indurated. Reed and Nelson (1980) reported sandstone beds as thick as $60 \mathrm{~m}$ at Falrview Mountain. Mineralogically, the sandstone is composed of about $75-85$ percent chert and quartz grains, 10-20 percent feldspar, and about 5 percent maflc grains (błotite, hornblende, clinozoisite, and chlorite). Tnterbedded siltstone and claystone nake up 20 percent of the Sandstone Member and are commonly light to medium gray, rooced, 


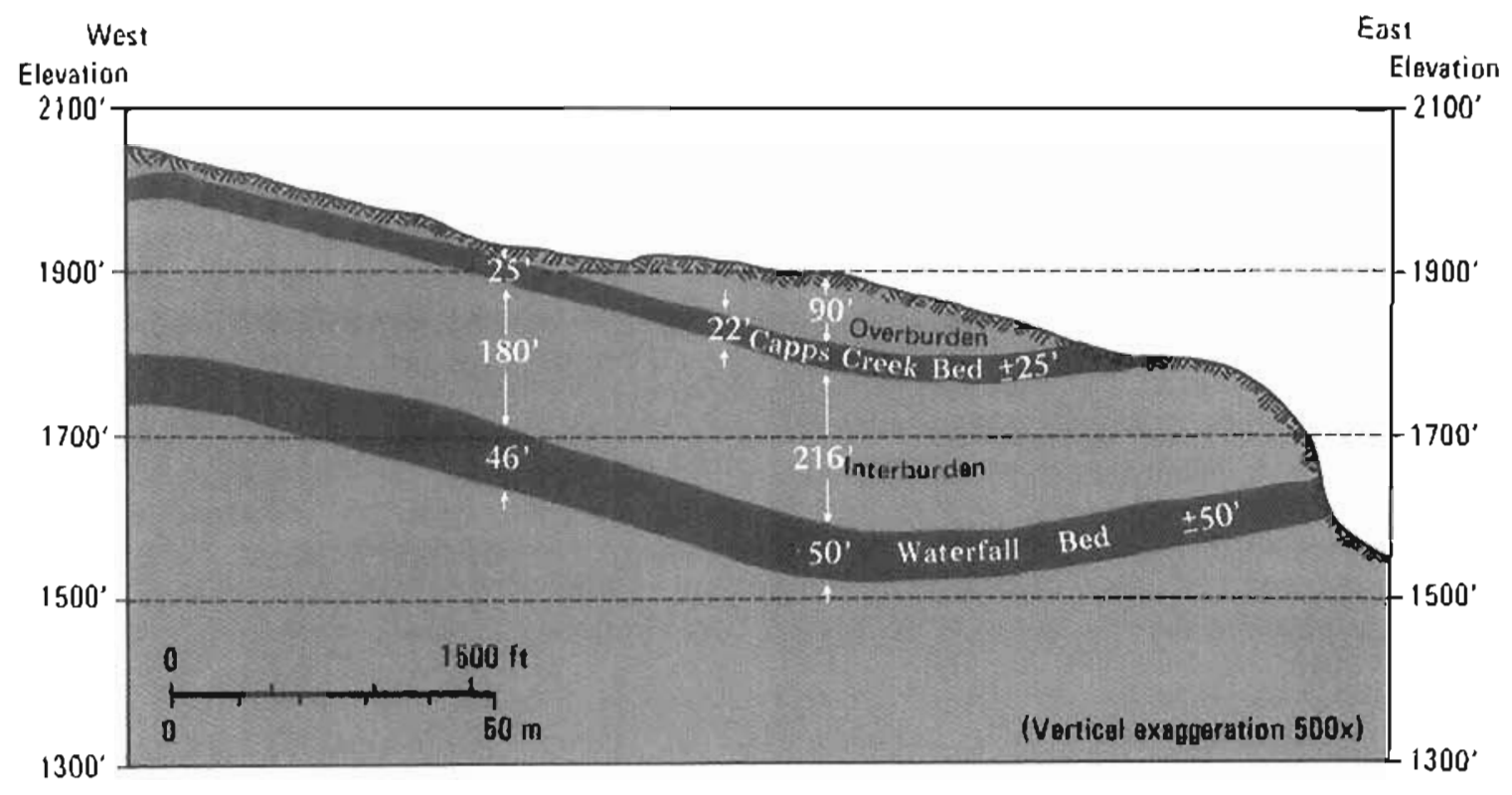

Figure 20. Generalized cross section of the Beluga coajfield in the Capps district showing thicknesses of the Capps and Wacerfall beds, including overburden and interburien zones. Modified from Conwell. (1977b).

and locally include coal stringers; they attint thicknesses to $50 \mathrm{~m}$. Conglomelate, coal, and volcanle ash compose <l percent of the Sandstone Member. The congJomerate occurs in beds to $5 \mathrm{~m}$ chlck, wich incorporated clasts that range to $10 \mathrm{~cm}$ di $\mathrm{am}$, but average $2-6 \mathrm{~cm}$ diam. The coals occur within Eining-upward (conglomerate-sandstone-siltstone-claystone-coal) cyclic sequences, often include carbonaceous shale or bone partings, and average <l $\mathrm{n}$ thick; however, they attain thicknesses of 3 in rithin the Sandstone Member.

Volcanjc-ash partings within the coal beds nay be as thick as $30 \mathrm{~cm}$ and consist of partially devitrified glass shards that have alcered to illite(?), with <0.5 percent biotite (Reed and Nelson, 1980). These ash partings often contain fossil roots and indicate that volcanic activity was contemporaneous with coal and sediment deposition.

The Conglonerate Member is generally light brown to blue gray, massively bedded, poorly indurated, and consists of 40 percent conglomerate, 20 percent sandstone, and 40 percent siltstone, claystone, and coal. Clasts of the petromictic conglomerate ranged to $15 \mathrm{~cm}$ diam but averaged $5-10 \mathrm{~cm}$ diam. Proportions of different lithologies vary; quartz and chert clasts are most abundant at Nakochna River; igneous-rock clasts predominate at Falrview Mountain. To the northeast from Nakochna River, shale and graywacke clasts increase proportionately to over 90 percent at Ruth Glacier. Grain sizes in the sedimentary rocks grade upward (coarse to fine) in cyclic units from conglonicrate co sandstone, sandy siltstone, silty claystone, and coal. Sandstone lenses are also poorly indurated and typically coarse-grained and pebbly. Coal beds of the Conglomerate Member average 0.6-3.0 m in thickness; four coal beds $(<2.2 \mathrm{~m}$ 


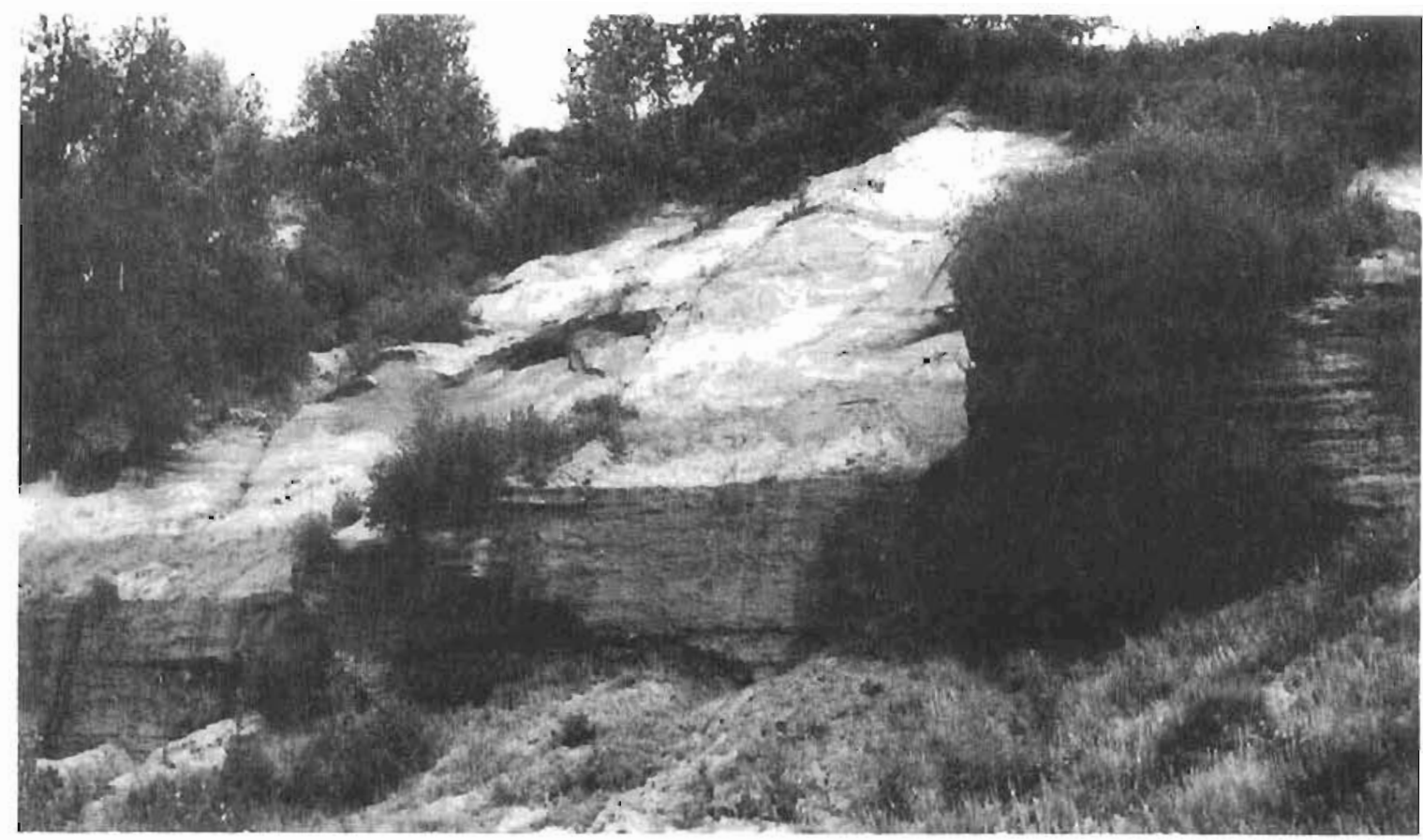

Figure 21. Outcrop of the Chuitna bed (Barnes, 1966; 'Brown Seam' of Ramsey, 1981b) along the Chuttna River (Tyonek Tormation, Bejuga coalfield). Photograph by J. E. Sperber, 1981.

thick each) are well exposed at Fairview Mountain (fig. 22); one tlick (4.5 m exposed) coal bed crops out along Camp Creek. These subbituminous coals are black to brownish black with a dull luster and usually contain clayscone, carbonaceous shale, or bone-coal partings. Occurtences of coal within the fairview Mountain region were first described by Capps (1913). Wolfe and others (1966) determined that an outcrop at Chicago Gulch was Seldovian (lower to middle Miocene).

The Tyonek Fornation is late Oligocene co middle Mlocme. Triplehorn and others (1977) obtained an age of $15.8 \mathrm{Ma}$ from a volcanic-ash parting in a coal bed of the upper Seldovian section of the Tyonek Formation along the Chuitna River. Time-stratigraphic markers, such as volcanic-ash partings, are rare in the Susitnd lowland. The geochemistry of an ash parting from the Capps bed (fig. 23) is consistent with its interpreted origin as an air-fall tufE (Spears and Kanaris-Sotirtou, 1979).

Rocks of the Tyoneir Formation are mostily products of channel and $1700 d-$ plain sedimentalion. Some coarse-gradned components indicate a near-source lithatype. Lacustrine deposits also occur locally.

The Tyonek Formation contains most of the coal resources of the Susitna lowland. The formation is widely distributed over the region, and its coals are generally chicker, more laterally concinuous, and of better quality (lower ash contents and higher heating values) than those of the Beluga and sterling Formations. 


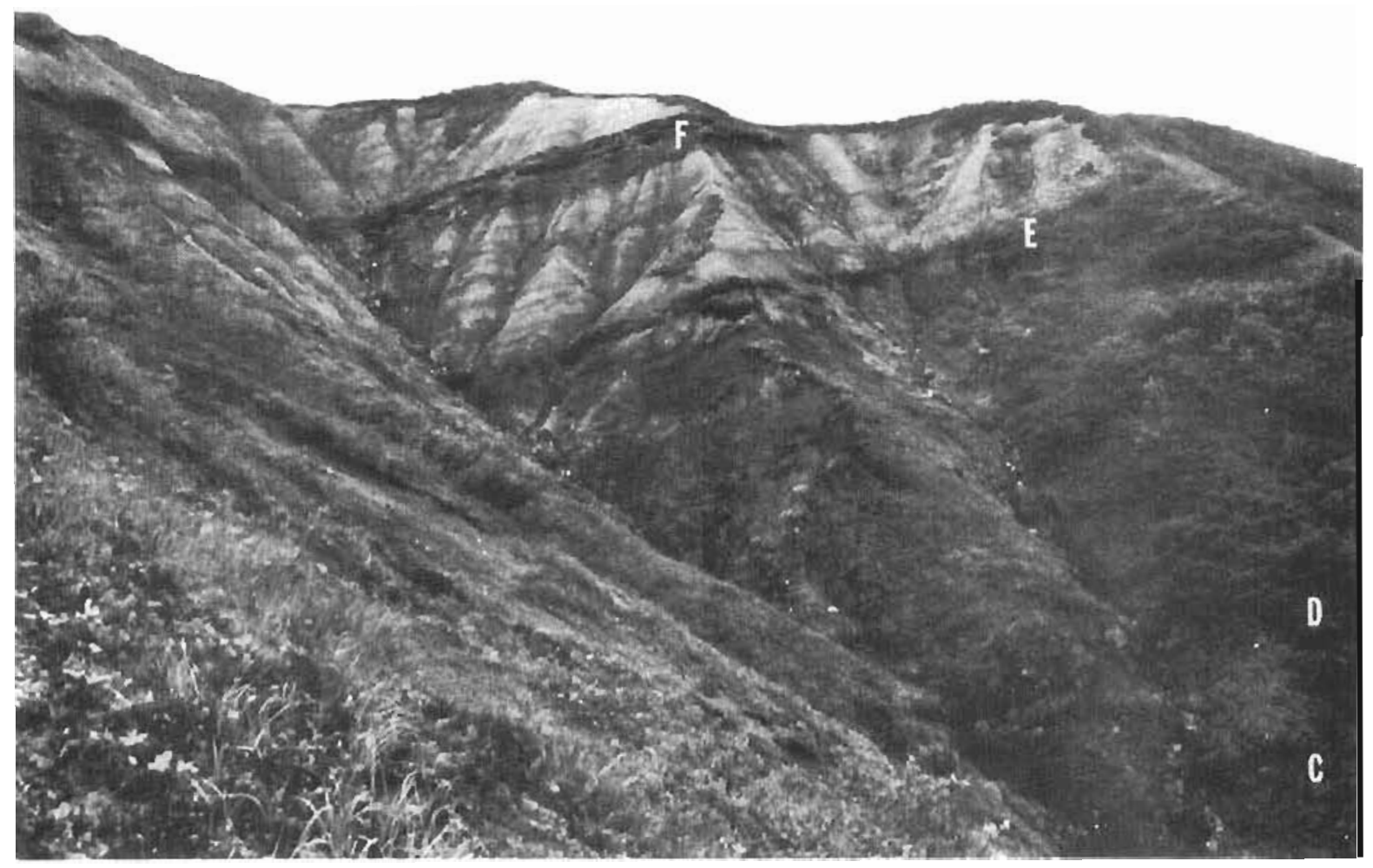

Eigure 22. Fairview Mountain coal beds (C through $F$ ) of the Conglomerate Menber of the Tyonek Formation, northest Susilna lowland. Photograph by J.li. Sperber, 1981.

\section{Reluga Fornialion}

'l'he beluga finmation crops out along the lower Deluge and Chuitua kivers and along Exaht lay east of Cranite Point (sheet 1). Total thickress of the Beluga Formation cannot be datermined from outcrops, but it is more than 1,200 $m$ thjck in the type section, a well near beluga (Schmoll and others, 1981 ). The coal sequence within the formation dips eastward beneath look lnlet and extends into the subsurface of the Kenai Peninsula (Sancisrs, 1981). The tormation consists of thin-bedded sundstones, cJaystones, and local ilgnitic corls with bentonitic claystone incerbeds; near basin margins, the formation grades into predominantly sandy siltstores, claystones, and bony coals. The wit is late Miocenc and is assigred to the Homerian Stage and lower part of the Clamgulchian Stage (wolfe, 1966).

The large pioportion of graywacke and greenstone lithic Eragments in pebbly endstone and conglumerate beds of the beluga Formation suggests tiat these sedinents nay have becn shed from the south and east during uplift of the Chugach Range; a secondary source area may be the Alaska Range to the north. The sedinents were probably deposited as coalescing alluvial tans on Eluvial plaims (Clardy, 1978) from source areas of moderate co low relief. 


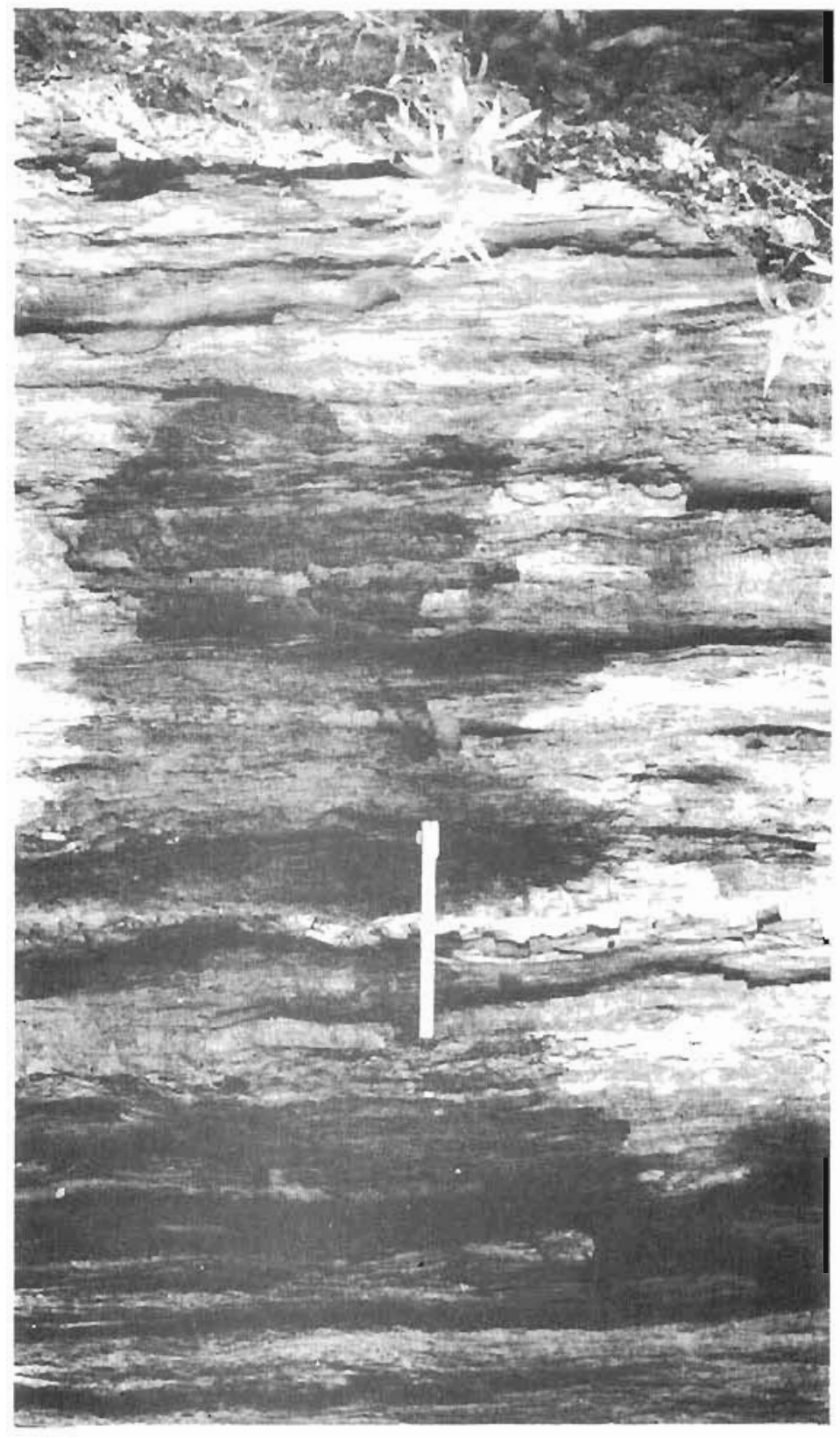

Figure 23. Volcandc-ash partings, il the Capps bed of the Tyorek Formation, Beluga coulfield. Photo by J.E. Sperber, 1981.

In the Susitna lowland, the Beluga Enxnation covers a much smaller area alil contains considerably less coal than the Tyonek Eomation; additiunally, the qualtty of Beluga formation coals is considerably lower.

\section{Sterljing Formation}

Sterling Formation strata were mapped by Reed and Nelson (1980) in the northern Yentna basin (sheet 1). At Fairview Mountin, the undt is $770 \mathrm{~m}$ thick. In the Beluga well, the unt overlies the Beluga Formation and, with Quaternary deposits, makes up the upper 1,I00 m of strata (Kelly, 1963). In the Yentria basin, the Steriing Fomation is a predomtnantly sandy, loosely consolidated unit with ninor claystone and a few relatively thin (2-m-thick) 
lignitic coals. Fetd and Nelson (1980) described it as an orange ro jightgray massive conglomerate with coarse-grained clastics. Clast diameters range to $30 \mathrm{~cm}$ but average $5-10 \mathrm{~cm}$ dian. Induration is typicaily poor to moderate with a clay or iror cxide (ferruginous) matrix. Clast ithologies are the same as in the Tyonek Foimation (quartz, chert, shale, graywacke, and igneous rochis but occur in different proportions.

l'he Sterling Eormition is late Riccene and Fliocene and falls withill the Clamgulchian Stage of Wolfe (1966). Triplehorn and others (1977) obtained $\mathrm{K}$-Ar ages ranginy from 6 to $11 \mathrm{Mg}$ from volcanic-ash partings within coal beds of the Sterling Formalion on the Kenai keninsula. Sterling Folmation deposits are probably characterstic of bralded streams that drained a tectonically active alca (Clardy, 1978). Near basin margins, the formation becomes conglomeratfc, incitcating a high-energy environment, near the source. Epidote dontnates the heavy-mineral sulte (Yirschner and Lyon, 1973). An inaication of provenance is the east-to-southeast current directions displayed in crossbedded sandstone lenses.

Coal deposits of the Sterling Formation are of minor signj.ficance compared with those of the Tyonek Formation. In the Susitna lowland, Sterling Formation coals of the northern Yentna basin are discontinuous and generally of low quality.

\section{PALEOBOTANY AND PALYNOLOGY}

The ages of Tertiary coal-bearing stratigraphic unfts in southcertral Alaska were established by the paleobotanical and palynological work of Wolfe and others (1966) who proposed three new provinclal chronostratigraphic units: the Seldovian, Homerian, and Clamgulchian Stages. Plant megafosisils and microfossils (spores and pollens) wert the criteria for age assignments ( $\mathrm{f} i \mathrm{~g} .24$ ). No megafossil or microfossil plants of Clamgulchian age have been found in the Suaftna lowland. Adkison and others (1975) measured numerous sections on the south side of Capps Glacier and at two localities along the Chuttna River, and provided detaiked lithologfc descriptions and lists of identified palynomorph assembiages.

From his study of leaf Floras of southwestern British Columbia and other parts of northwestern North America, holfe (1978) concluded that middle Eocene time was characterized by widespread equable clinates. The warm and temperace broadlecf furests were no longer dominant after middle Miocene time, and cool temperace floral familee such as Betulaceae (birch) proliferated (Wolfe, 1972, 1977; Wolfe and others, 1980).

Willisms and Ross (1979) also postulated a period of widespread equable climates in their stuoy of Eocene coal-bearing strata in the Iulameen coalfield of southcentral Fititish Columbia. This type of climate is inferred in most lertiary models (Kirschner and Lyon, 1973) and likeiy was characteristlc of the period auring deposition of the coal-bearing Tyonek Formation in the Kenai Group. The relatively lush plant growth of a lowland-plain paleoenvironment would account for formation of the thyck peats and (ultimately) thick ccisis of the Tyonek Formation. 


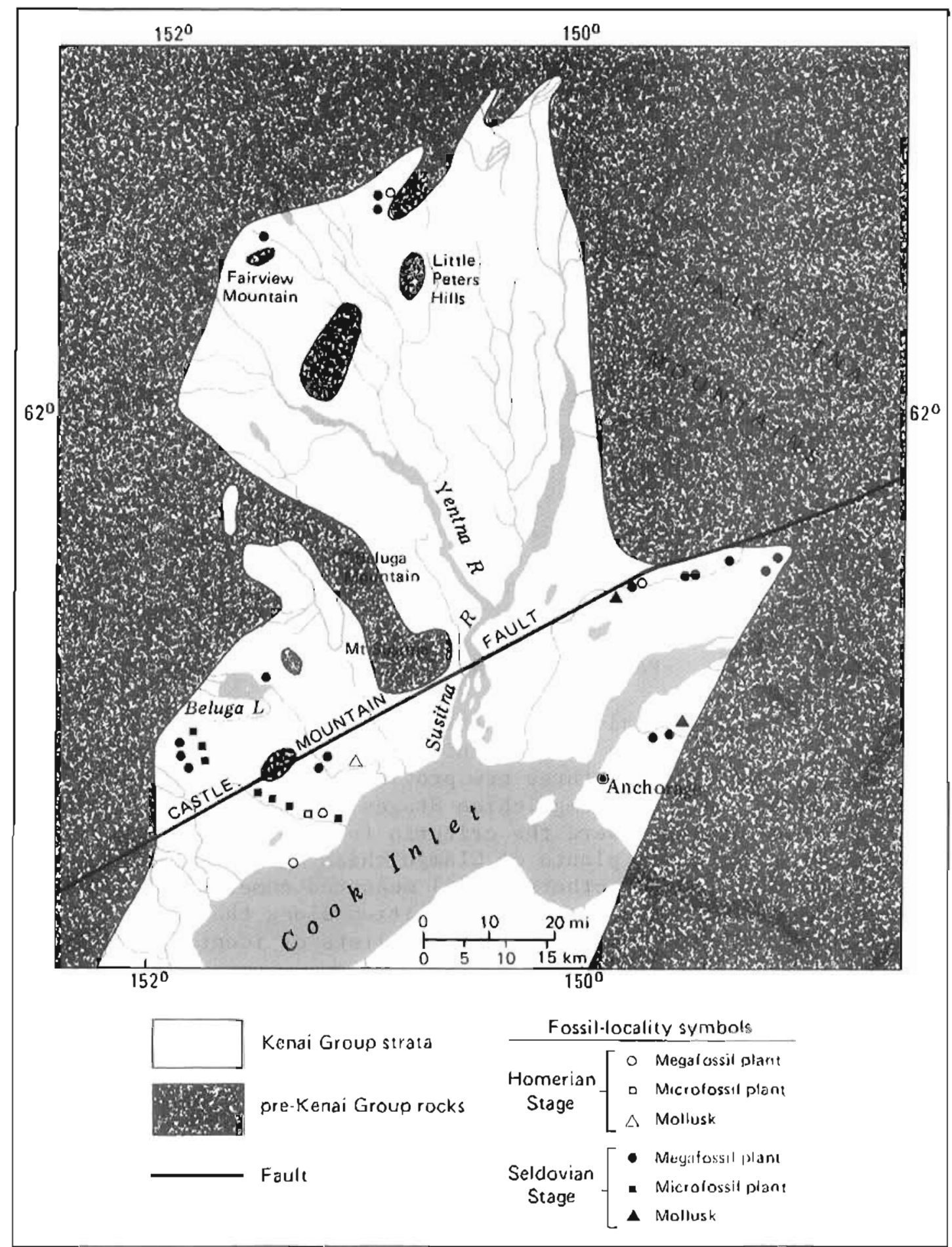

Figure 24. Seldovian and Homerian Stage fossil localities in the Susitna lowland. Modified from Wolfe and others (1966). 


\section{PETROGRAPHY OF TYONLK FORMATTON ROCKS}

Sand scontes

\section{Conposicion}

Sandstones of the lyonek Formatior examined during this scudy (sample locaclons on pl. I; lescriptions in app. C) were predoninantly medium grained and vatied from gray to brown, locally slightly tintea green or blue. Graded bedding was common, and lining-upward sequences were tratistional from coarsegrained sandstone at the hase to fine-grained sandstonc and siltstone upsection. Sandstones consisterl predominanty of quartz and rock iragments in an argillacecus matrix or cemenced by silica. Feldspar, mica, and heavy nimerals were minor accessory components.

Quartz graius langed from silt to pebble size. Plutonic (with vacuoles) exhibiting strain sladows and vein quartz exhiblting slight to strong undulatory extinction rere nost abundant. Minor quartz probably originated from metamorphic rocks; a few polycrystalljue or mosalc grains vere also observed.

Rock frugments vere usually not abundant ( 5 percent), but occasionally ranged to 25 percent; one sample of coarse-grained sandstone consisted of over 50 percent lithic components. Most fragments were of sedimentary orlgin with secondary metamorphic types. Shale fragments (carbonaceous or bituminous) and disseminated and finely divided coal detritus were common. other sedinentary components included chert and cherty sandstone, argillaceous sandstone, and argilite (sometimes silicifled). Metamorphic fragments included quatzite, slate, chlortte, and muscovite.

Feldspar, predominantly plagloclabe, typically constiluted < 3 percent; $1 t$ occurred in twinled (alblte and Carlsbad) and untwinned varieties. Microcline occurred in a few saniples. Almost all feldspar gralns were highly altered to serj.clie, chlorlte, or other clays; some had limonite rims. Relatively fresh feldspar grains uf pyroclastic origin(?) were not observed in the sandstone.

Blotite, the most abundant mica ( compaction and often alcered to kaolinite clay. Sericite mixed with chlortte, prochlorite, are clay typically constituted < 2 percent, muscovice < 1 percent.

Opaque and heavy minerals were estimated at <5 percent in modal analyses but occasionily ranged to 15 percent. The heavy minerals usually occurred as lsolated grains but íl some samples were concentrated ir defined lamillae; among those identifted were tourmaline, apatite, rutile, zircon, garnet, epidote (the latter $\leqq l$ percent), clinozoisite ( $\leqq 5$ percent), and hornblende. Typically, 10-50 percent of the heavy-nineral fraction was opaque.

Most saridstone examined had siijceous or argillaceous matrix. Often silica and clay were mixed. Cryptocrystalline silj.ci was a common matrix material (1ncluding void-filiing chalcedony) and was the cement in most samples; ferruginous and sometimes silty clays were also common cements. Illite and kalinite were most abundant, usually stained by fron oxides and hydroxides and mixed with sericite, chlorite, and chlorophaeite. A small proportion of the clay uninerals were authígenic. Ir. finer grained sandstones, clay constituted 20-30 percent of the matrix. 


\section{Classification}

Lithic or sublithic arenite and graywacke were the predominant sandstone rypes. Protoquartzites or orthoquartzites were not present in the 'Tyonck Formation samples analyzed.

Roundness, sorting, and textural maturity

Most quartz grains were subangular to subrounded. A few well-rounded grains were undoubtedly recycled and some showed abraded overgrowths. Some clay-coaced frains also occurred, either recycled or with the coat formed authigenjcally by alteration. Chert clasts were typlcally more angular than quartz, especially in the coarser grailled sandstone. Sorting was generally poor to moderate, and most sandstone was submature to irmature.

\section{Claystone}

Claystone is conmon in the coal-bearing strata of the Tyonek Formacion in the Susitna lowland. It may be silty or sandy locally and 1 s often carbunaceous (with shreds of organic matter, coaly streaks, and carbonized plant fragments) or ferruginous (with tron oxjdc and hydroxide mottles, irregular patches, encrustations, rims, and fracture coats) and contains highly altered slate, quártzite, and graphitic or phylitic schist iragments. It is cryptocrystallire, with included flakes typically ortented parallel to the bedding planes; it may have discontinuous, very fine laminae. Some samples were banded with light ancl clark lenses of finer and coarser grained materfal. The lighter lamellae were siltiex and contained significantly more quartz than the darker lameilae of clay. Underclays commonly contalned fossil roots, and sometimes regular black cryptogranular spheres that may be pollen grains. claystone. color ranged through shades of gray and brown, sometimes with tints of red, yellow, and green. Root casts were sometimes observed, and shrinkage cracks also accurred in some samples.

$X$-ray diffraction of claystone samples revealed that 1 ilite-kaolinite associations are most ccmmon, with secondary abundances of mixed-layer minerals such as chlorite and montmor1jlonite. Mixed-layer minerals and illite compete for the same siles, causirig illite peaks to appear fairly broad and asymetrlc on diffractograms. The illite may also be poorly ordered because of surficial weathering. Chlorite, clinochlore, and serictte occur as alteration products of hornblende or other ferromagnesian silfcates and are intermixed with other clays. In the samples, kenlinite exhibited generally lower. birefringence than did lilite and sericite.

Cryptocrystalline quartz occurred in most thin sections of claystone as scatteleo minute fragments, smäl and irregular silicic veins and veinlets, and cav1ty fl].1.ings; chalcedony and opal were common. Quartz constitured <10 percent in most modal analyses but was usually the second main constluent.

Minor or accessory minerals and inclustons occurred in the claystone in rumerous forms; carbonaceous (organic) matter was $<7$ percent on a modal basis. Opaque minerals were usual1y $<5$ percent. Blocite was the predominant mica ( $<5$ percent) with minor muscovite (<1 percent), both highly altered; clinozoisite (often 2-7 percent) was more abundant than epidote (usually < percent). 
Other occurrences included anatase, garnet, spinel, tourmaline, laumontite (zeolite in slate and schisc fragments), and antigorite. Calcite, dolomite, siderdte, and pyrite were extremely rare in these fine-textured sedinents.

Carbonaceous shale

Carbonaceous shale is rare in coal-bearing strata of the lyonek Formation in the Sustena lowland, typically occurring in very thin $(<0.5 \mathrm{~m})$ beds of reddish to dark brow or black undifferentlated clay and fine silt next to coal seams. Irregular, silicic veinlets and cavity Eillings of cryptocrystalline quartz transecced carionaceous fragments. Minor accessory minerala included Iron oxides and hydroxides, clinozojste, epldote, sericite (minute shreds), muscovite, cryptogranular chlorite, feldspar (alcering to clinozolsite), anatase, and tourmaline.

\section{Carbonate content and concretions}

The carbonate content of Tyonek Pormation rocks studied was very low. Siderite concretions and differentially calcium-carbonate-cemented sandstone lenses occurred locally in coal-bearing sections. Microscoplcally, the rocks included a mixture of very fine-grained calcite and siderite with argillaceous matter and silt-sized to fine sand-sized quartz. The Jenses and concretions occurred in sections near Capps, Wolverine, and Saturday Creeks. The differentially cemented lenses were most abundant in sandstone, whereas the siderite concretions occurred mafnly in silty shale. Sone concretions had weathering rinds of limonice or hematite.

\section{T'onsteins}

Several tonsteins have been identifled as thin claystone partings in coal seams of the Tyonek Formation. Ovoids of relatively clear kaolinite are definitive of graupen tonsteins. The major-oxide geochemistry for two tonsteins (table 3) was gencially consistent with an air-fall cuff origin. $x$-ray diffraction of one tonstein (fig. 25) showed the chief constituent to be kaolinite; the samples contalned little quartz. The high phosphate

Table 3. Majomoxide geochemistry of two coal ton. steins from the Susitna Lowland.

\begin{tabular}{|c|c|c|}
\hline Oxicle & $\begin{array}{c}\text { Sample } \\
\text { CnC7-12 }\end{array}$ & $\begin{array}{l}\text { Sample } \\
\text { CG } 1-6\end{array}$ \\
\hline $\mathrm{SiO}_{2}$ & 26.37 & 40.63 \\
\hline $\mathrm{Al}_{2} \mathrm{O}_{3}$ & 21.02 & 31.31 \\
\hline $\mathrm{Fe}_{2} \mathrm{O}_{3}$ & 1.22 & 0.42 \\
\hline $\mathrm{MnO}$ & 0.00 & 0.01 \\
\hline $\mathrm{MgO}$ & 0.15 & 0.09 \\
\hline $\mathrm{CaO}$ & 3.28 & 0.62 \\
\hline $\mathrm{Na}_{2} \mathrm{O}$ & 0.00 & 0.13 \\
\hline $\mathrm{K}_{2} \mathrm{O}$ & 0.39 & 0.20 \\
\hline $\mathrm{TiO}_{2}$ & 0.61 & 1.67 \\
\hline $\mathrm{P}_{2} \mathrm{O}_{5}$ & 8.64 & 0.13 \\
\hline $\left.\mathrm{LO}^{2}\right]^{3}$ & 20.94 & 20,00 \\
\hline $\mathrm{H}_{2} \mathrm{O}$. & 88.86 & $96.4 \hat{3}$ \\
\hline
\end{tabular}




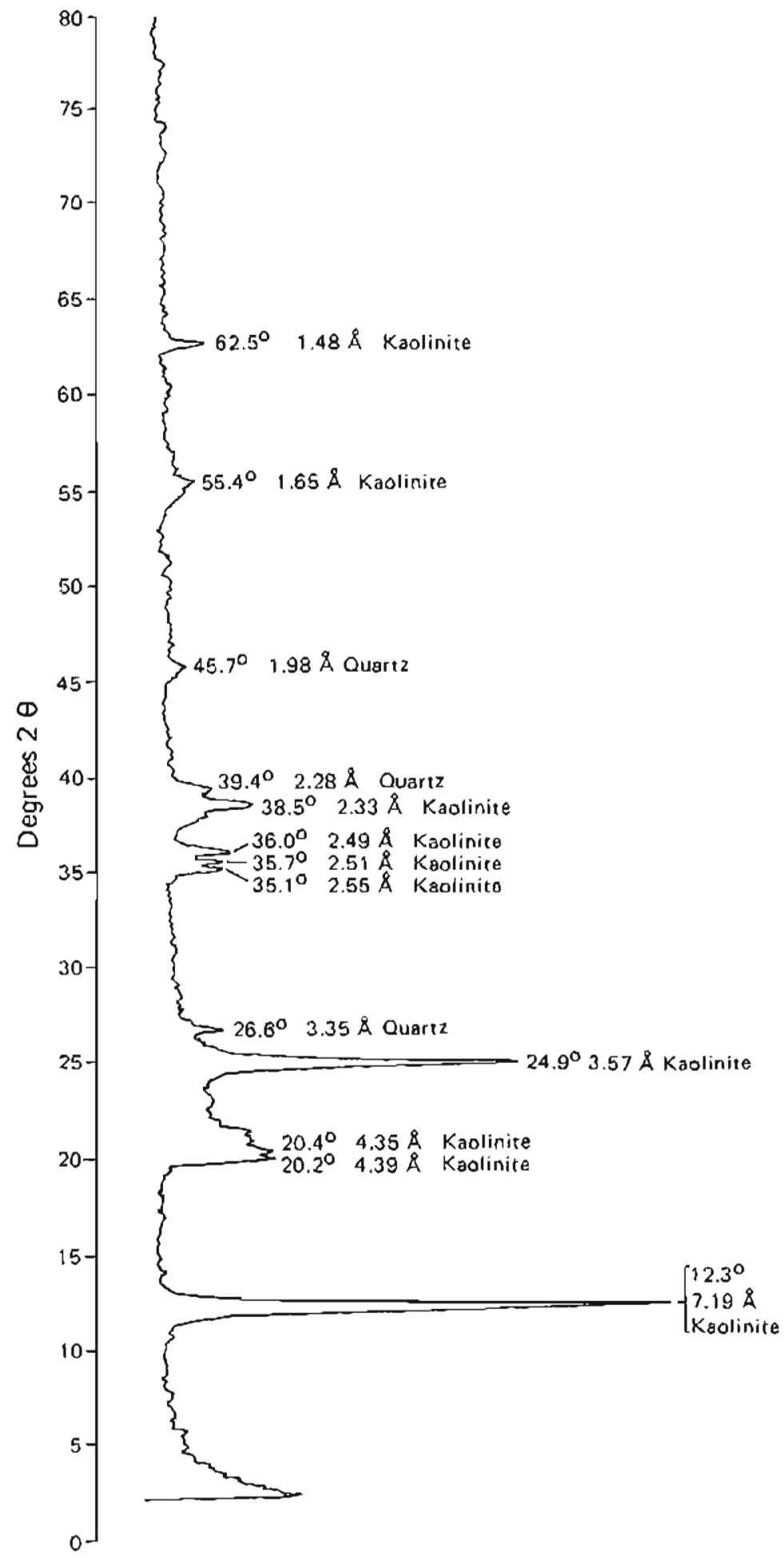

Figure 25. X-ray diffractogram of a coal tonstein (sample CG4-6) from the Capps bed. The chief constituent is kaolinite. 
content in sample $\mathrm{CnC7}-12$ was tentatively identified by X-ray diffraction as goyazite $\left[\mathrm{SrAl}_{3}\left(\mathrm{PO}_{4}\right)_{2} \cdot(\mathrm{OH})_{5} \cdot \mathrm{H}_{2} \mathrm{O}\right]$ or gorceixite $\left[\mathrm{BaAl}_{5}\left(\mathrm{PO}_{4}\right)_{2} \cdot(\mathrm{OH})_{1}\right.$ ] ], members of an isostructural group of rhombohedral phosphates of the plumbogumite fanitly (Price and Duff, 1969). A cefinitive identification of a specific hydrated aluminum phosphate was not made because other minerals of the series had similar $2 \theta$ angles and peak incensities. Relatively high titárium (particularly noticeable in sample (G4-6) probably occurs as anatase, which was identified petrographically.

The tonstein samples CG4-6 and $\mathrm{CnC7}-12$ exhibitid the textures and general features of a palagonite tuff or recrystallized baked clay. Angular fragments (sometimes shards) of red and black devitrifled (to various stages) volcanic glass were present. Kaolinite was often intermixed with iron oxides and hydroxIdes (goethite, limonite, and heratite) and showed paraliel orientation with aggregate polarization. Chlorite and cryptogranular alteration products were concentrated along silícic (chalcedonic) veinlets; clinozoisite, epidote, and sericice also occurred as alterations.

Baked rocks

Several thermally altered rocks were also examined petrographically. The rocks were baked or burned by the natural combustion of adjacent coal beds or by an intruding dike or underlying sill. The degree of alteration is directly proportional to the rock's distance from the burning seam or ignecus intrusion. A contact auxeole caused by metamorphism 1 s formed around the burned zone or intrusion. Ultimate products of the two processes (natural baking vs. contact metamorphtsm) are very simllar and may be difficult to distinguish in a local area, particularly if a coal seam has burned underground.

A series of laked rocks (samples CnC3-1 through CnC3-5, table 4) was sampled at an upper Canyon Creek locality of the western Susitna lowland (fig, 26).

Table 4. Majom oxide geochemistry of a gradaliond series of baked rocks from an upper Canyon Creek locality.

\begin{tabular}{|c|c|c|}
\hline $\begin{array}{l}\text { Major } \\
\text { oxide }\end{array}$ & $\mathrm{CnC} 3-1^{a}$ & $\mathrm{CnC} 3 \cdot 2^{\mathrm{b}}$ \\
\hline $\mathrm{SiO}_{2}$ & 49.32 & 69.60 \\
\hline $\mathrm{Al}_{2} \mathrm{O}_{3}$ & 29.26 & 18.22 \\
\hline $\mathrm{Fe}_{2} \mathrm{O}_{3}$ & 1.93 & 1.02 \\
\hline $\mathrm{MnO}$ & 0.01 & 0.01 \\
\hline $\mathrm{MgO}$ & 0.21 & 0.04 \\
\hline $\mathrm{CaO}$ & 0.70 & 0.55 \\
\hline $\mathrm{Na}_{2} \mathrm{O}$ & 0.22 & 0.24 \\
\hline $\mathrm{K}_{2} \mathrm{O}$ & 0.46 & 0.48 \\
\hline $\mathrm{TiO}_{2}$ & 0.62 & 0.96 \\
\hline $\mathrm{P}_{2} \mathrm{O}_{5}$ & 0.18 & 0.17 \\
\hline LOI & 9.97 & 3.88 \\
\hline $\mathrm{H}_{2} \mathrm{O}$ & 6.37 & 2.54 \\
\hline Total & 96.25 & 37.71 \\
\hline
\end{tabular}

Sample

$\mathrm{CnC} 3.3^{\circ}$

49.03

36.50

2.17

0.02

0.25

1.00

0.26

0.56

0.67

0.27

2.91

2.44

96.08

\begin{tabular}{c}
$\mathrm{CnC}^{-4} 4^{\mathrm{d}}$ \\
\hline 46.06 \\
34.96 \\
4.36 \\
0.15 \\
0.56 \\
2.34 \\
0.66 \\
1.12 \\
0.74 \\
0.44 \\
2.65 \\
2.25 \\
96.29
\end{tabular}

$\mathrm{CnC} 3.5^{\mathrm{e}}$

67.56

15.06

4.20

0.07

0.20

0.47

4.71

3.50

0.41

0.14

1.07

0.68

97.97 


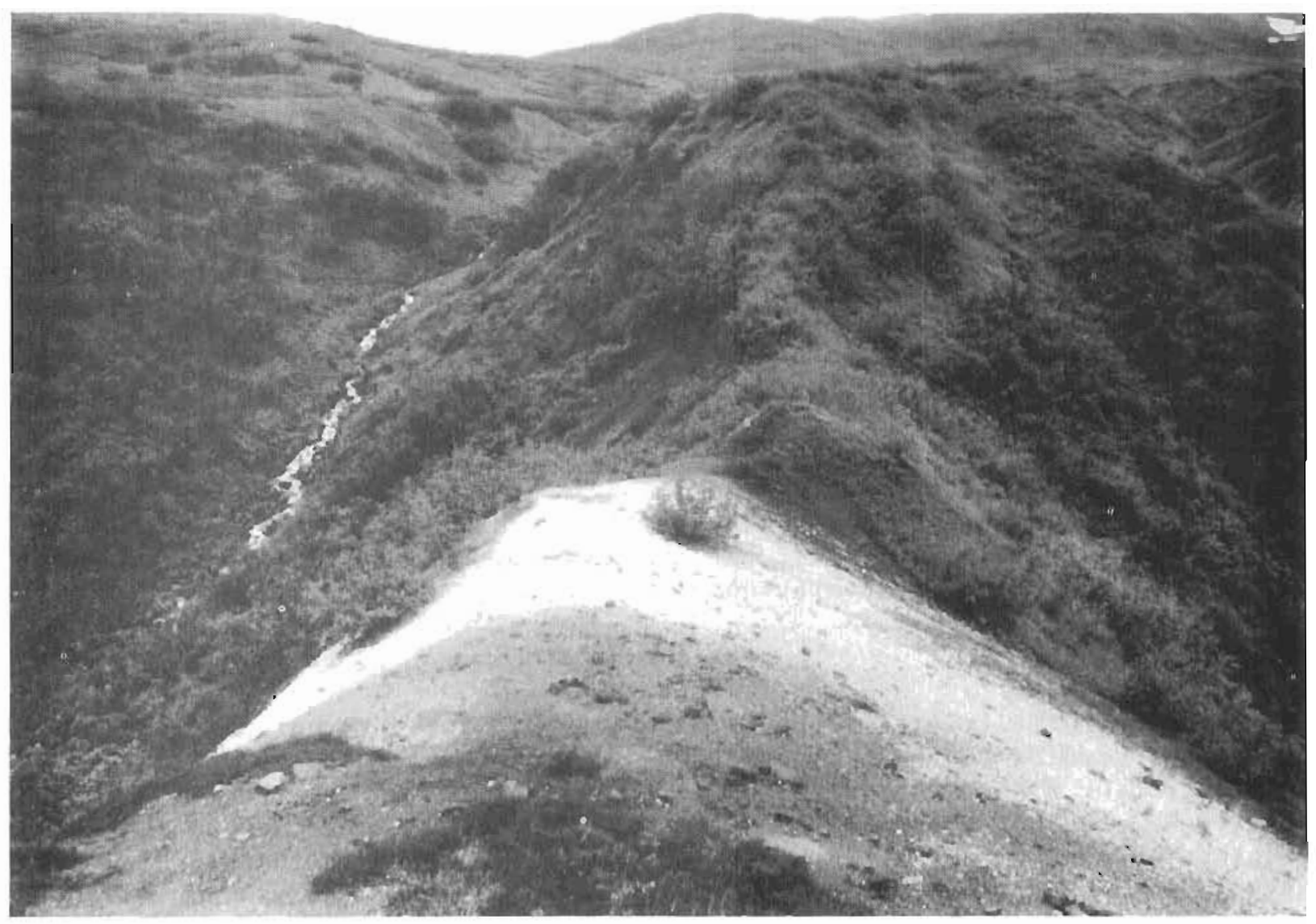

Figure 26. Gradational zones of burn material in a coal-bearing section of the Tyonek Formation, upper Canyon Creek, southwest Ventna basin. l'holograph by 1.E. Sperber, 1981.

Although these rocks nay have been altered by an underlying late Tertiary dike or sill, they were probably baked by the burning of an adjacent undersround coal seam. Table 4 shows the geochemical changes that occur in baking: ( 1 ) a general. increase in total iron as $\mathrm{Fe}_{2} \mathrm{O}_{3} ;$ (2) an tncrease in $\mathrm{Na}_{2} \mathrm{O}$ and $\mathrm{K}_{2} \mathrm{O}$; and (3) an expected decrease in $\mathrm{H}_{2} \mathrm{O}$ and LOI. No trends were noted in other major oxides.

The baked claystones had a very fine grained matrix that extinguished in two principal. Jirections. Pores, voids, and veinlets were commonly filled with cryptocrystaline quartz. Tdentification of individual minerals became more difficult with increased alteration, because the minera!s had recryst.l? . lized and showed indefinite boundaries, with flow banding and glass sometimes observable jn thin scetion. 


\section{DEPOSITIONAL ENVIRONMENTS OF KENAI GROUP COALS}

Source areas adjacent to basins of the Susitna lowland were rejuvenated during Late Cretaccolls and early Tertiary time. Periodic or gradual uplift converted bastral flood plalus into coal-forming environments by late oligocene to middle Miocene time, when the Tyonck Formation was deposited. Vegetal and woody materials accumulated, and peat formed in these stagnanc depositional areas. The ground-water table gradually rose, and the sediment supply was restricted, which also promuted peat formation.

Subsidence rates varied from area to area; gradual subsidence with periodic stillstands resulted in formation of coal swams in paleotopographically low areas between flood events. At any one time, peat or coal would have been forming in relatively small areas of the region, as evidenced by the lack of extensive 1 ateral continuity of the seams. Coal-seam partings also reveal monuniform conditions over the Susitna lowland and indicate lateral shlfting of swamps and other subenvironments.

Tertiary coal-bear1ng strata of the Kena1 Group in the Susitna lowland have characteristics common to many continental fluvial models (see pl. 2). These predictive paleoenvironmental models are useful as exploration tools (for example, Horne and others, 1978) to indlcate drill spacing during design of drilling programs. As channels and basin onargins are approached, a closer spacing is required to delineate seam vagarles (Howell and Ferm, 1980). The thickest seams in a particular depostcional basin usually occur next to depocenters and thin toward the periphery. Thicker coals within the continental fluvtal system tend to parallel the depositional dip (Ryer, 1981). Paleoenvironmental models are useful as well in assessing coal quality and overburden characteristics during mine planning and in predicting geologic, geochenical (including hydrogeochenical), and environmental problems during mining and reclamation.

Fluvial depositional environments and subenvironments (natural levees, point bars, lakes, lacustrint deltas, abandoned-channel fllis, crevasse splays and backswamps) influenced coal-seam and overburden characteriatics of this reglme (figs. 27 and 28; table 5). Backswamp deposits ideally constst of basal seatrock (ofteil underclay), coal, and overlytng carbonacenus shale. Discontinufites or splits in coal seams often represent ancient levee deposits of active channels, Including crevasse splays, and local, pod-shaped coal bodies commonly represent accumulations of organlc material next to meander channels of 1ushly vegetated ancient flood plains. Rapid sedimentation during floods buried this vegetacion and frequently preserved upright stumps or kettles (Horne and others, 1978; fig. 29).

Dickinson and Camphe11 (1978) pointed to certain depositional environments for Tertfary Kena: Group sedjmentary rocks th the Peters Hills and Fairview Mountajn areas (most Likely Tyonek Formation) of the Susitna lowland and concluded that some of these congiomerates and sandstones Indlcate near-source deposition in mudflows and proximal bralded-stream systems on alluvial fans, whereas other conglomerates and sandstones of this region are characteristic of distal braided-channel and flood-platn deposits. They reported that these rocks are typically arkosic, oxidized at the surface, and composed mainly of 


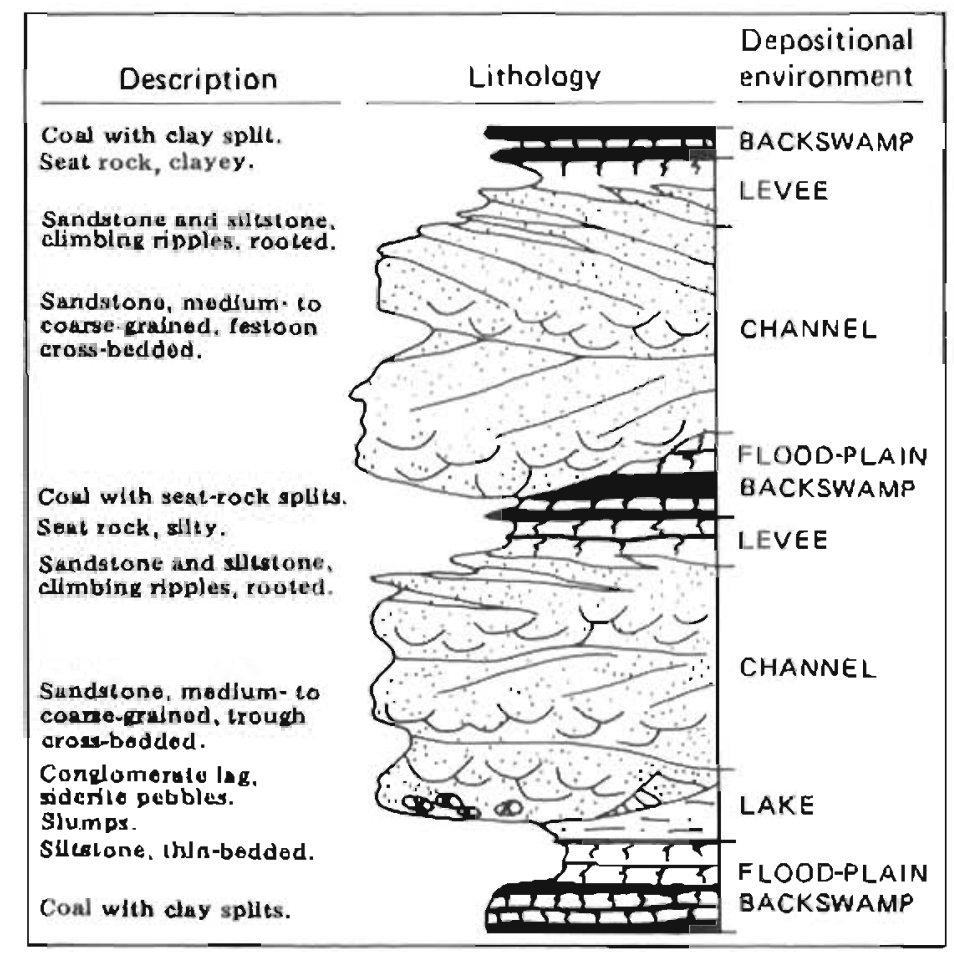

Figure 27. Generalized vertjcal sequence or continental fluvial deposits. Mndified from Horuc and others (1978).

quartz, plagioclase, and lesser orthoclase. Carbonaceous mudstone, claystone, and coal formed in interchannel lacustrine and paludal areas. The mudstone and claystone contain abundant illite and chlorite clay minerals, with minor siderite and calcium carbonate concretions.

A small synclinal basin east of Beluga lake in the Susitna lowland contains a thick coal scam that may represent a lacustrine coal (fig. 30); it is simliar to the basin-center coal and fringing marginal-shale-facies lacustrine model proposed by Hacquebard and Donaldson (1969) for basins in Nova Scotia.

Channels (represented now by channel-fill deposits) directly affect the minability of a particular coal seam (Horne and others, 1978); they are con-

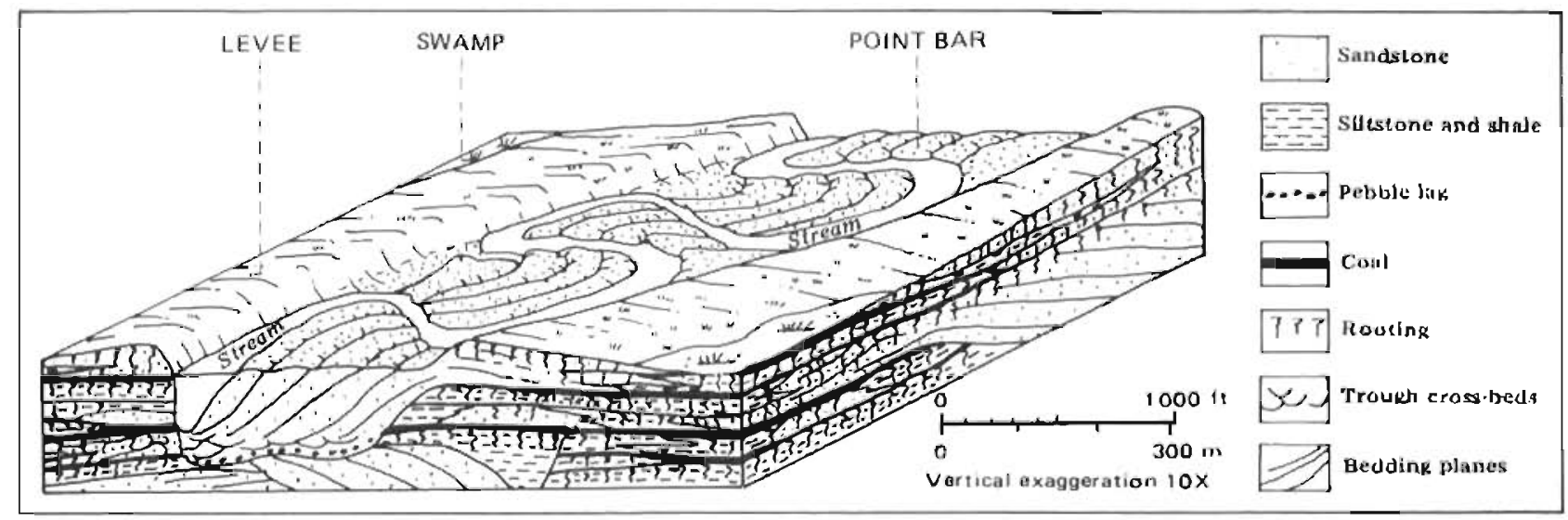

Figure 28. Llock diagram of concinental fluvial environments typlcal of the Susitna lowland. Modified from Horne and others (1978). 
temporaneous with or postdate peat accumulation. A small paleochannel in a section of the Tyonek Formation near the western margin of the Susitna lowland has eroded much of a Saturday creek coal seam.

Most stratigraphic sequences within the Tyonek Formation of the Kena1 Group display a fining-upward character. Although at some locales the formation displays cycilic characteristics, these are not classic cyclothems. A rypical full cyclic sequence includes (from bottom to top) conglomerate, often an immature petronictic conglomerate; pebbly, very coarse grained sandstone; medium- to coarse-grained sandstone; fine-grained sandstone; fine-grained sandstone interbedded with shale and siltstone; underclay, carbonaceous shale, or siltstone; and coal. A complete cycle is extremely rare because of erosion and cruncation. Full sequences are predicted to occur rearer the depositing chanrel (Duff and others, 1967).

Table 5. Criteria for recognition of fluvial depositional environments (from Home and others, 1978).

\begin{tabular}{|c|}
\hline Characteristic \\
\hline Coaysening upward \\
\hline Shale and siltstone sequences \\
\hline Greater than $50 \mathrm{ft}$ \\
\hline 5 to $25 \mathrm{ft}$ \\
\hline Sandstone seguences \\
\hline Greater than $50 \mathrm{ft}$ \\
\hline 5 to $25 \mathrm{fl}$ \\
\hline Channel cleposils \\
\hline \multirow{2}{*}{$\begin{array}{l}\text { Fine-grained abandoned cill } \\
\text { Clay and silt }\end{array}$} \\
\hline \\
\hline Organic clebris \\
\hline Active sandstonc fill \\
\hline Fine grained \\
\hline Medium and coar'se grained \\
\hline Pchlole lags \\
\hline Conl spar \\
\hline Contacts \\
\hline Abrupt (scour) \\
\hline Gradational \\
\hline Cross-beds \\
\hline Ripples \\
\hline Ripple drift \\
\hline Herringbone Cestoon \\
\hline Gracled beds \\
\hline Point bar accretions \\
\hline In'egular bedding \\
\hline Levee rleposits \\
\hline Minernlogy of sandstones \\
\hline Lithic graywacke \\
\hline Ortliocuartzites \\
\hline Fossils \\
\hline Marine \\
\hline Brackish \\
\hline Fresh \\
\hline Burrove structures \\
\hline
\end{tabular}

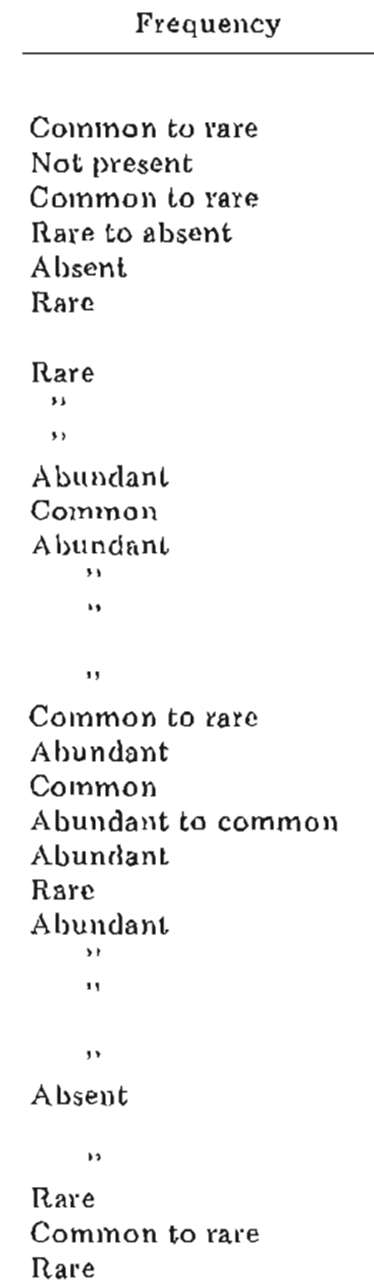




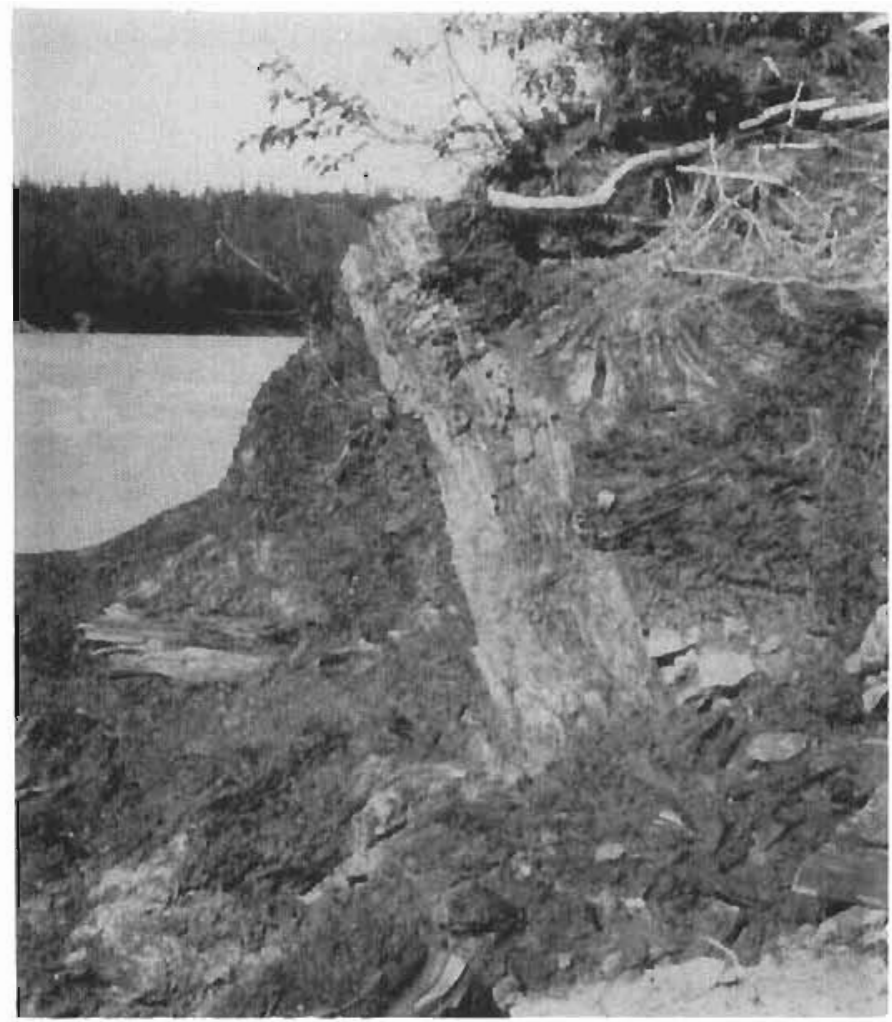

Figure 29. In-place, upright tree stump in woody coal (Beluga Formation) aluig the Beluga River, southern Susitna lowland. Photo by J.G. Clough, 1981 .

These cycles result from sinifrs of channel and sedimenc deposition across an alluvial plain. The coarser basal uiits represent lateral-accretion deposIts and are commonly crossbedded. The upper, finer grained, ulits represent overbank and lake or swamp deposits. As proposed, the Elow-regime triensity progressively decreases upward in the section.

Cycliclty in the Susitna lowland was best preserved at Fafrview Mouncain (sheets 1 and 2; app. C). A statistical Markov-chain analysis was applied to the sequence based on the repetitiun of the five major rnck types (conglomerate, sandstone, shale, claystone, and coal). The enalysis followed the procedure outlined by Gingertch (1969) For Paleocene fluvial sedimentary rocks in the northern Bighorn basin of Wyoming. Calculations related to the analysis of the Fairview Mountain section are included as appendix D. With $x^{2}=35.9$ and 15 degrees of freedom, it is highly dmprobable that the Fairview Mountain sequence was deposited by an independent or non-Markovian mechanism; evidence indicates cyclic sedimentation in an alluvial environment (f $\mathrm{g}$. 3l).

These cycles indicate quiescent periods (cectonic lulis) during the Tertiary Period when large areas of basin flood plains became coal-forming swamps. These tectonic lulls were interrupted by pertods of uplfft and relatively rapid basin subsidence accompanied by the influx of clastic materials. In general, the Tertiary Period was a time of widespread but discontinuous coal formation in the Susitna lowland. Conditions conducive for coal formation were most favorable during late oligocene to middle Miocene time, when the Tyonek rormation was deposited. 


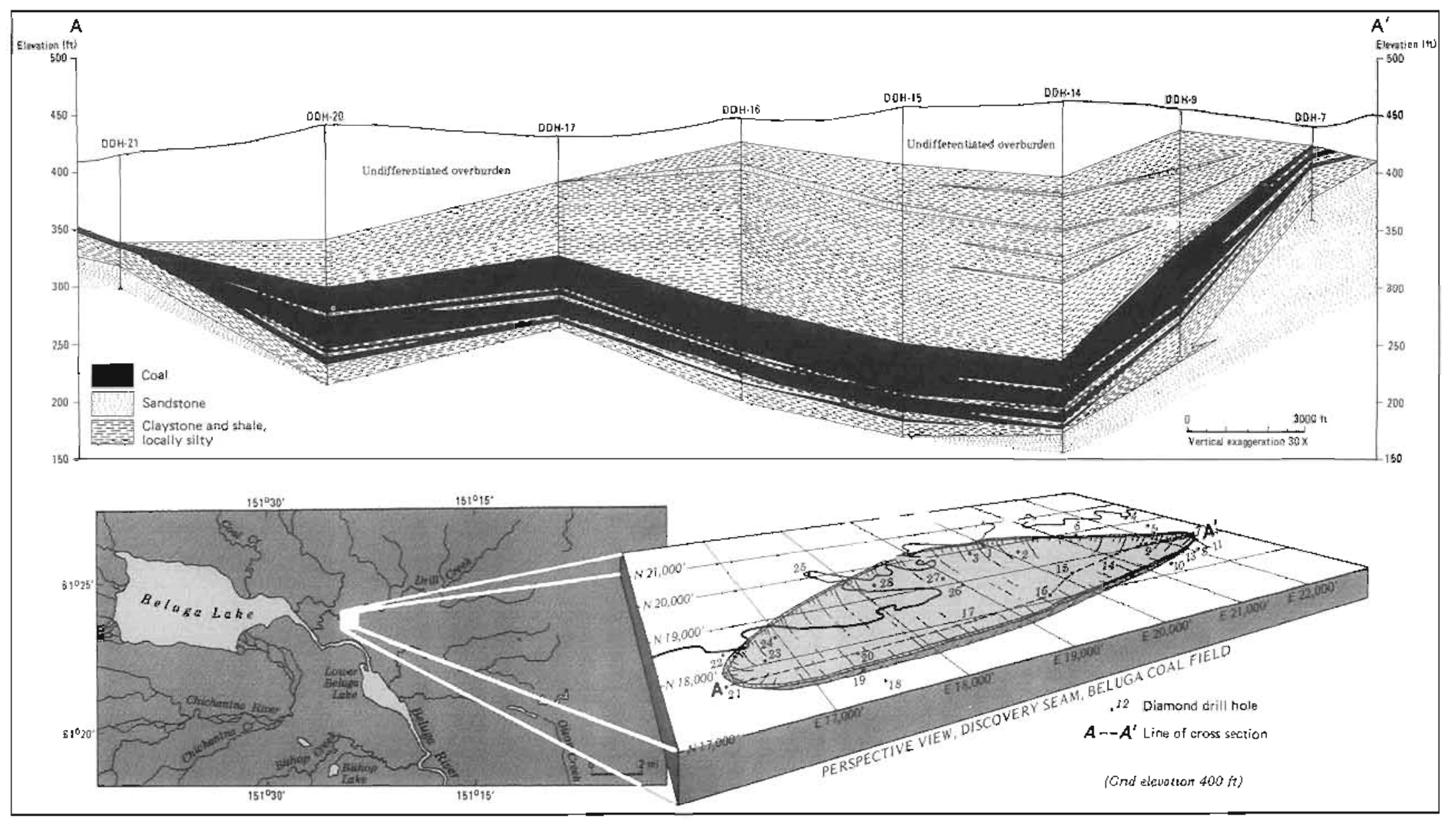

Figure 30. Ceologic cross section of a lacustrine deposit in the Beluga coalfield. Lower insets (modilied from Warfield, 1962) show the location of the deposit. 


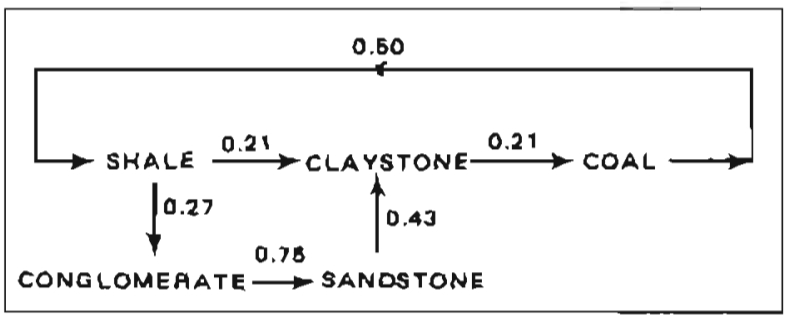

Fl.gure 31. Probabilities of various transitions in lithology in a coal-bearing section of the Tyonek Formation, Falrview Mountain.

Various workers have related the paleosalinity of strata to paleoenvironmental interpretation; for example, to decipher marine transgressions and regressions. Couch (1971) calculated paleosalinteies from boron and clay-mineral data. Bohor and Gluskoter (1973) used boron in 1llite as an indicator of paleosalinity in Illinols coals; Berner and others (1979) used authigenic iron sulfides.

Using exchangeable cations and water-soluble cations as paleosalinity indicators, Spears (1973; 1974) found that the concentration of exchangeable magnestum is higher in marine shales, and the concentrations of exchangeable calcium, sodium, and potassium lower, than in nonmarine and brackish shales; he correlated the changes in exchangeable cations to paleosalinity throughout the sequence and postulated that these changes more likely occurred during halmyrolysis (submarine weathering) than during diagenesis (1973, p. 79, 81). He proposed (1974) that high concentrations of water-soluble calcium and magnesium cations reflect marine-influenced environments, whereas low concentrations are dlagnostic of freshwater and bracklsh-water paleoenvironments; sodium and potassium have reverse trends.

Figure 32 shows consfderable variation in the ammonium acetate extractable cattons and total catton-exchange capacity (CEC) for a coal-bearing section in the Tyonek Formation near Peters Hills. Increases in extractable Mg+t, Cat+, and $\mathrm{K}+$ are mirrored by an increase in total CEC. Spears (1973) found a corresponding decrease in total CEC with increasing exchangeable magnesium. Changes in CEC are also directly related to changes in mineralogy; in this example, a reduction in CEC simply reflects a decrease in the amount of clay and 15 probably related to provenance. The Peters Hills section was probably deposited in continental fluvial environments, and the variations are therefore not related to transitioris with marine environments. 


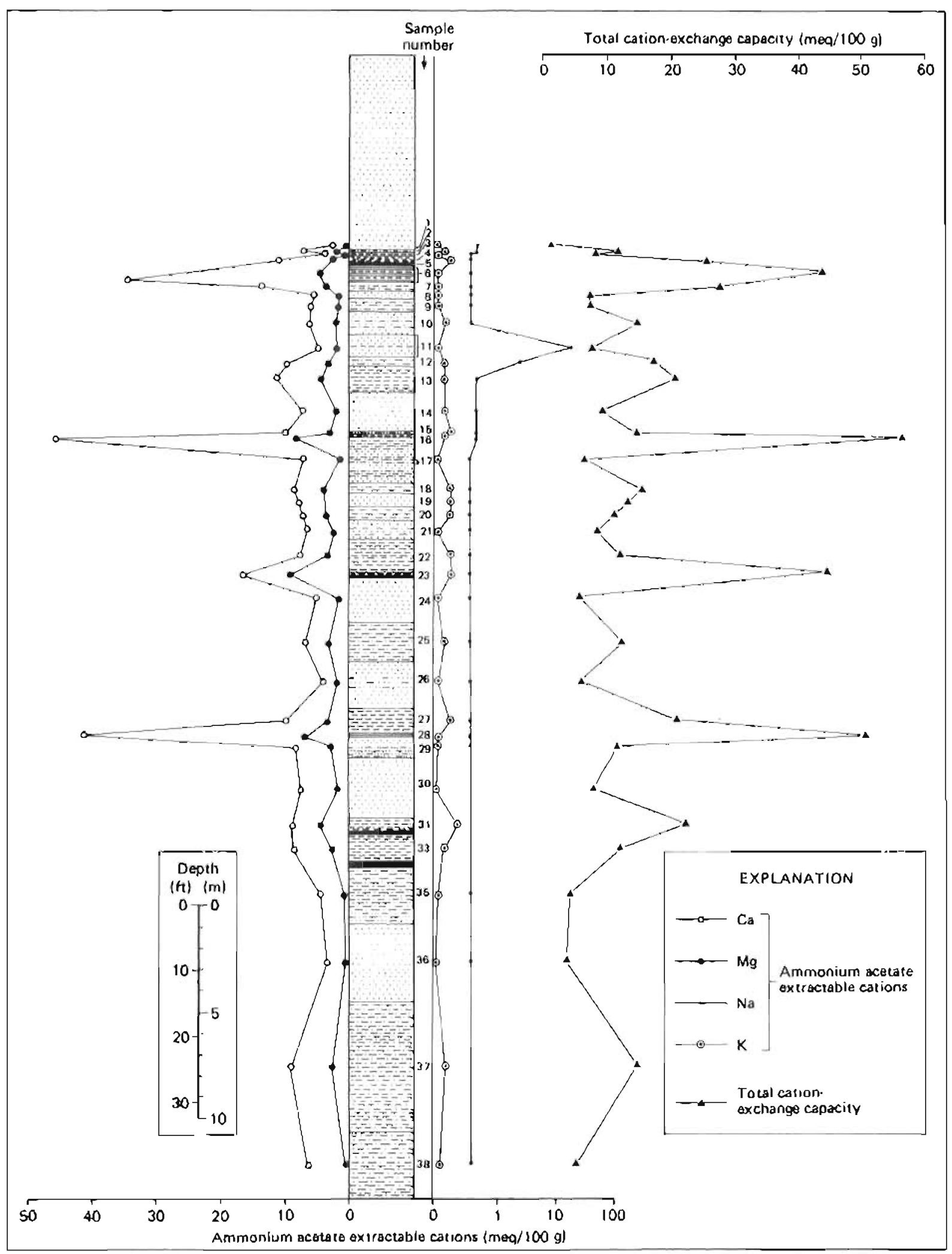

Figure 32. Varjation in ammonium acetate extractable cations and total cationexchange capactty (CEC) for a coal-bearing section in the Pecers Hills ared (east Yentna Field, Tyonek Formation). 


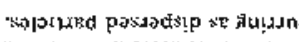

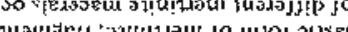

(3)

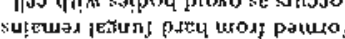

प

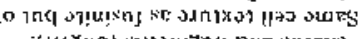

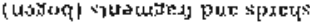

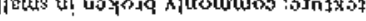

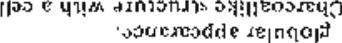

axFप flim tom

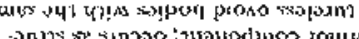

a

19.

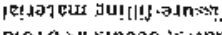

作

(2)

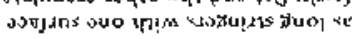

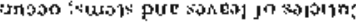

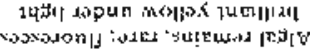

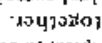

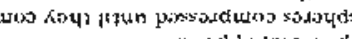

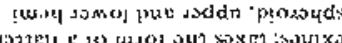
PUE ?

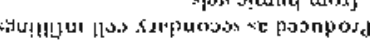

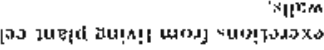

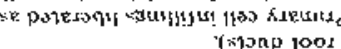

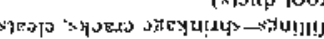

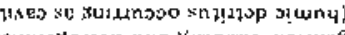

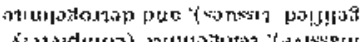

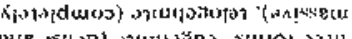

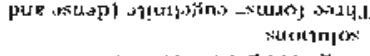

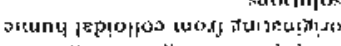

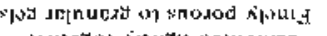

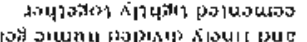

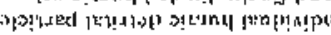

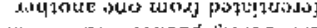

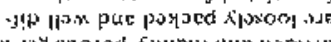

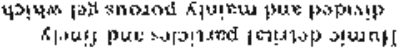

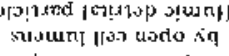

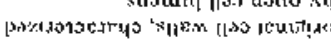

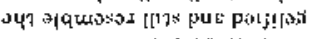

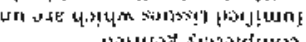

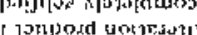

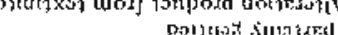

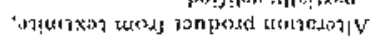

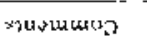

*71

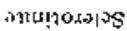

a!Lren!lus

An!u!:ng

भ!บ!ฺEIK

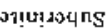

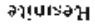

काาำำ

जाएवार

anumads

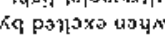
क्रstonu IIY

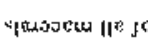

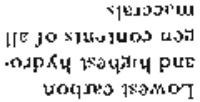

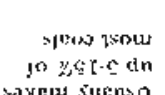

- Trest penom pur

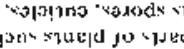
snougrat pure $\alpha$ sem (opurgat

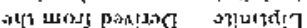

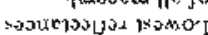

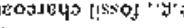
(1) papestop pue pasot

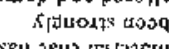
jugipt uraj prostao

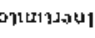

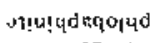

$$
\text { opnosd }
$$

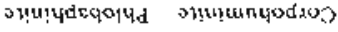

m.า

\begin{tabular}{|c|c|}
\hline 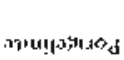 & 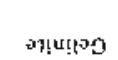 \\
\hline - & 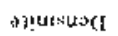 \\
\hline . & 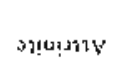 \\
\hline
\end{tabular}

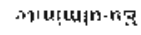

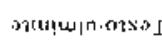

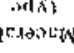

mitum

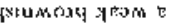

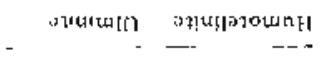
यदง |CITPEN

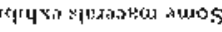

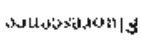


COAL PETROLOGY

Coal-pellet preparation and petrologic analysis

The procedures of the International Commitree on Coal Petrology (1963) and the terminology for brown coal from Stach and otheis (1975) were adopted for this petrologje analysis of susitna lowland coals (table 6). A 50-y sample of each coal ( -20 mesh) was kneaded with epoxy resin as a binder and briquetted in 3,2-cm-diam molds with a hydraulic press at 4,000-5,000 psi. The pellets were consecutively ground using a Buehler automet, a $120-\mu$ diamond lap, and a $30-\mu$ metal-bonded diamond lap, and then polished in $1-$ and $0.05-\mu$ aluminum oxicle suspensions ( $2 \mathrm{mjn}$ each stage).

A Swift point councer was used to quantitatively determine macelals. On each pel1 tet, I, Onc counts were made along a grdd traverse. The maceral content was recurded on a volume-percent and mineral-matter-firee basis. No separate count was made for liptinite macerals and fluorescent huminites under fluorescent incident-lighe excitation; however, liptinites were studied under blue ultravinlet light, and representative photomicrographs of the different types were taken. The fluorescence system consisted of a Leftz SmLux microscope with a Plocmpak fluorescence incjdent-light illuminator and 100-W mercury lamp fitted with an I2 cube (Roo and WolfE, 1981).

Reflectance measurements were made on a Leitz Ortholux triocular-body microscope equipped with an MPV-3 system with a motorized drive stage. A square-leat diaphrign with a $5-\mu^{2}$ measuring area on the specimen was used. In addition, an intericrence filter. was fitted to give a peak cransmittance at \$46-nm wavelength. Bausch and Lomb optical glasses were used as reflectance standards. The mean maximum reflectance of ulminite particles was measured in oll along equally spaced traverses; 100 measurements were made on each sample. Before reflectance measurements were taken, polished pellets were dried in a desiccator (Rao and Wolff, 1981).

\section{Maceral composition}

Macerals, the organic constituents of coal--analogous to minerals in rocks--are tdentified by their diagnostic morphology and reflectance; however, the respectuve maceral composition of a coal gives only part of an overall picture, because of complex chemical composition and mineral-matter content. Structurally intact cell walls and relatively unstructured fine, granular materials (for example, mineral matter, fragmented charcoal, and fungal remains) sometimes occur. Hithough the maceral compositions usually reflect changes in the primary vegetation cover, thermal effects may remove less resistant macerals such as extnoids from the assemblage. The materials forming peats are subjected to difierent conditions before burial beneath a sediment cover. The changes that occur in the eventual maceral compositions ultimately determine the coal's quality and heating value.

Maceral compositions for Susitna lowland coal samples analyzed in this study are summarjzed in table 7 and on figure 33. Raw coals iromi different areas within the Susicna lowland have similar maceral-group proportions. however, the relative contents of indjuidual macerals and maceral types may vary considerably within a seam and among difrerent seams, as shown in photomicrographs of coals from the region (figs. 34 and 35 ). 
Table 7. Summary of maceral composition of 180 coal samples from the Susima Lowland. (Reported on a volume-percent, moisture and ash-free basis.)

Ulminite
Porigelinite
Phlobaphinite
Pseudophlobaphinite
Humodetrinite

Total luminite

Fusinite

Semifusinite

Selerotinite

Macrinite

Inertodelrinite

Total inertinite

Cutinite

Sporinite

Resinite

Suberinite

Alginite

Total liptinite

\begin{tabular}{r} 
Range $(\%)$ \\
\hline $15.8 \cdot 99.0$ \\
$0.0 \cdot 35.4$ \\
$0.0 \cdot 18.2$ \\
$0.0 \cdot 21.6$ \\
$0.2-63.2$ \\
$76.6 \cdot 100.0$
\end{tabular}

$0.0-9.6$

$0.0-5.2$

$0.0-1.4$

$0.0-2.0$

$0.0 \cdot 5.2$

$0.0 \cdot 18.6$

$0.0^{-} \quad 3.4$

$0.0-5.6$

$0.0 \cdot 9.2$

$0.0 \cdot 3.8$

$0.0 \cdot 2.0$

$0.0 \cdot 11.8$

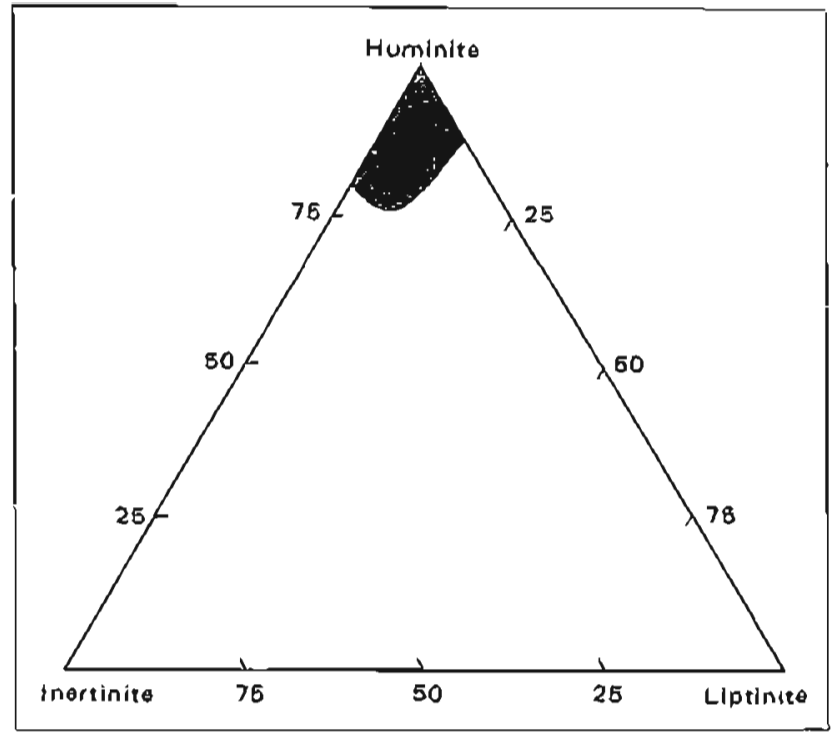

Figure 33. Ternary diagram for maceral-group compositions of Susitna lowland coal samples.

Huminite macerals were by far the most abundant in coajs of the Susitna lowland; the huminite group typically accounted for 90 percent, and never $<75$ percent, of all macerals (see table 7). Ulminite, the main huminite to occur, was medium to light gray, generally uniform in structure and reflectance, and sometimes displayed desiccation cracks or microfractures. Texto-ulminite was partially gelified, and eu-ulminite was completely gelified. Corpohuminites occurred as phlobaphinite (primary cell infillings) and pseudophlobaphinite. (secondary cell infillings). Pseudovitrinite was extremely rare and was not identifled. According to Rao and Wolff (1981), humodetrinite content (finely dispersed humic debris) is most abundant in the top seam of a cosl-bearing sequence. They postulated that the changing paleoenvironmental regime caused phystcal degradation of humic matter and ended conditions conducive to coal formation. This trend was not well established in most Susitna lowland coal-bearing sequences but was observed in some coal-bearing sections.

Mean-maximum-reflectance values for all coals as measured from ulmintte macerals are listed in appendix $B$, table B-3, compared by respective ASTM (Americar Society of Testing and Materials) rank in table B-4, and summarized in figure 36. Reflectance values ranged from 0.23 to 0.45 percent, which conflrms that most coals are subbituminous to lignitic. Little variation occurred in the reflectance values within a seam or among seams.

Inertintes commonly occurred as minor constituents in Susitna lowland coals. However, several seams, particularly those in the northern Yentna coalfield at Falrview Mountain and in the Peters Hills area, ylelded samples with inertinitic contents of more than 18 pexcent by volume on a mineralmatter-free basis (see table 7). These inertinltes were typically white or 
very light gray and bright in normal incident light and exhibited the highest reflectance of all the macerals. Macrintte, fustnite, and soriffusinite preoominated, but thertodetrinile (dispersed clastlc fragments of inertintte) and sclerotinite (hard fungal remains usually in young coals, as those of the Tertiary Period) were also observed. Sclerotia were rounded or elitptical, with lumens or cavities occasionally cortaining resinite, pyrite, or other minetal matter. Mucrinite was not identified in coals of this region.

The inertinites were affected by more intense physical and chemical alteration than were the huminites, but both are chlefly derived from wood and bark. The inertinites may have been attacked by bacterla before burlal. Fusfnitic and semifusinitic components consisted of charcoal and other partially burned materials. These macerals are thermally resistant and inert; hence, they are not easily oxidized or hydrogenated. Rao and wolff (1981) lound that the concentration of inert macerals increased from the base to the top of a given seam, and they belleved this trend to reflect a gradual change to a drier paleoenviroment during, coal formation.

Liptinites (exinttcs) in Susitna lowland coal samples ranged to about 12 percent by volume on a mineral-matter-free basis (table 7). Resinite and suberinite were the most abundant. Liptinites have the lowest reflectances of all. macerals. They are black to dark gray in normal incident 1 ight, but fluoresce under blue-11ght frradiation. Liptinites share broad chemical affinities, such as relatively high hydrogen and volutile contents; comparte with other maceral groups, they have a higher concentration of aljphatic substances such as tar. liptintes car represent diverse coal components that range from spore and pollen exines and perines to cuticles, algae, and other resinous substances, and tannin derivatives (Spackman and others, 1976).

Resinfte occurred as cell fillings of lumens, or as secretions, and sometimes as isolated, elongate, or spherical bodies; resintte typically displays an orange fluorescence. Fxsudatinite, included with resintte, commonly fills cracks in vitrinite (ulminite), cell lumina of fusinite, or chambers of sclerotinite (Spackman and others, 1976). Suberinite is common in Tertiary coals and originates from cork cell walls, mainly in bark and root tissue. Yellow stringers (In fluorescent light) of cutinite were typically crenulated or serrated on one side, thin walled (tenulcutinfte) or thick walled (crassicutinite), and sometimes folded. Sporintte cccurred as flattened elongate bodles with slitted centers. Alginites (preserved algal remains) were rare in the Susitna lowland coal samples; alginites fluoresce yellow under blue-light irradjatlon.

Hydrogenation (increasing the hydrogen content of a coal) is vital to the liquefaction and gasificatjon processes. General.ly, the vitrinite and exinite components of a ccal can be hydrogenated but inertinites cannot; further petro$\log i c$ ard characterization research wil. I help determine potential alternative uses and beneficiation processes that can be applied to susitna lowland coals.

Paleoenvironmental Interpretation for maceral compositions and assuciations

Paleoenvironmental interpretation Exom coal petrology begins with an understanding of the concept of microlithorypes--associacions or macerals of the same group or assoctations with those from other maceral groups. They can 


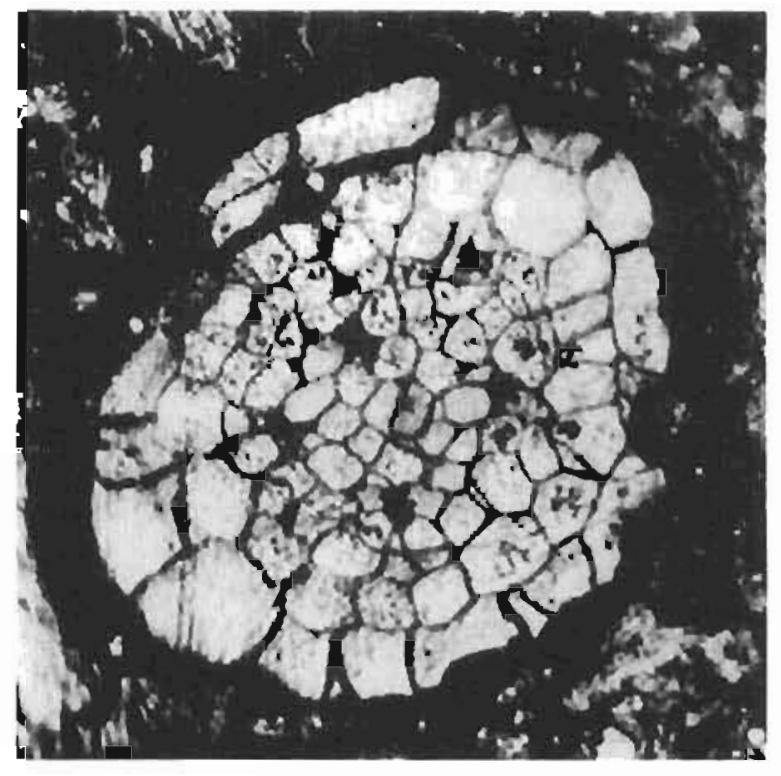

a. Phlobarlinite and porigelinite (PA3-lp; wag. 400X).

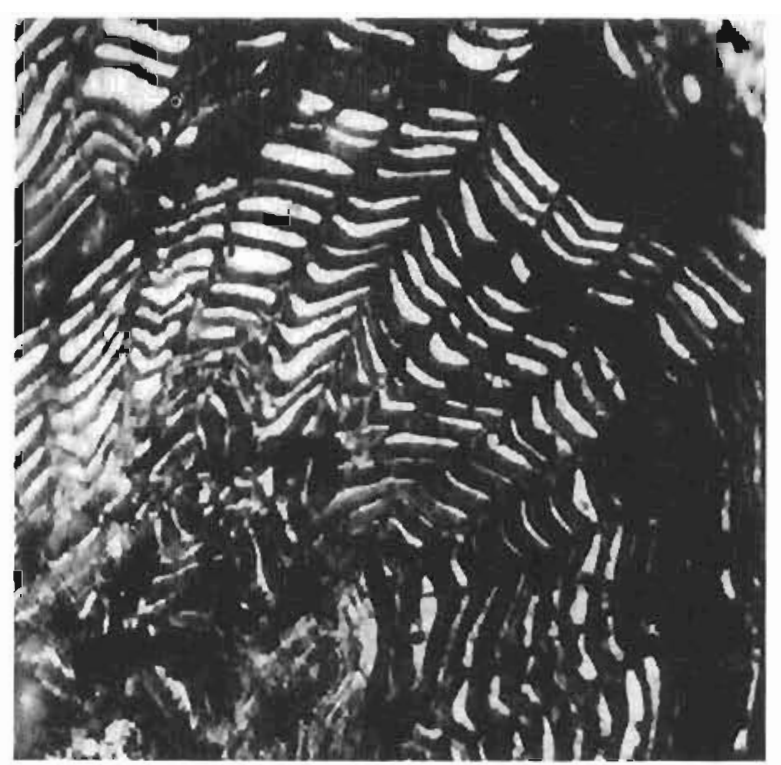

c. Phiobaphinice cell fillings and thick suberinite cell walls (PA3-lp; mag. 400X).

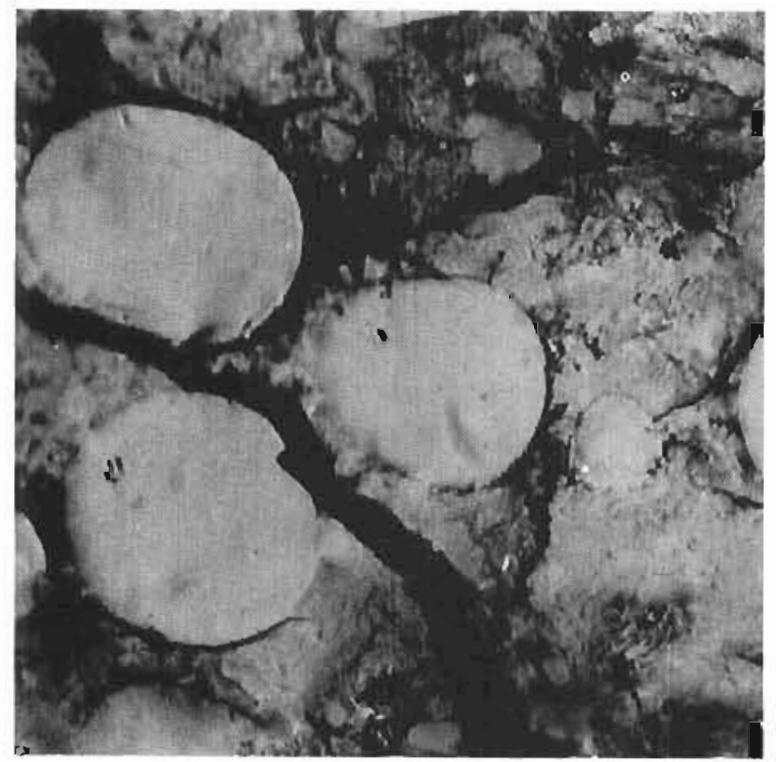

b. Pseudophtolsiphinites (CC3-3p; mag. 250X).

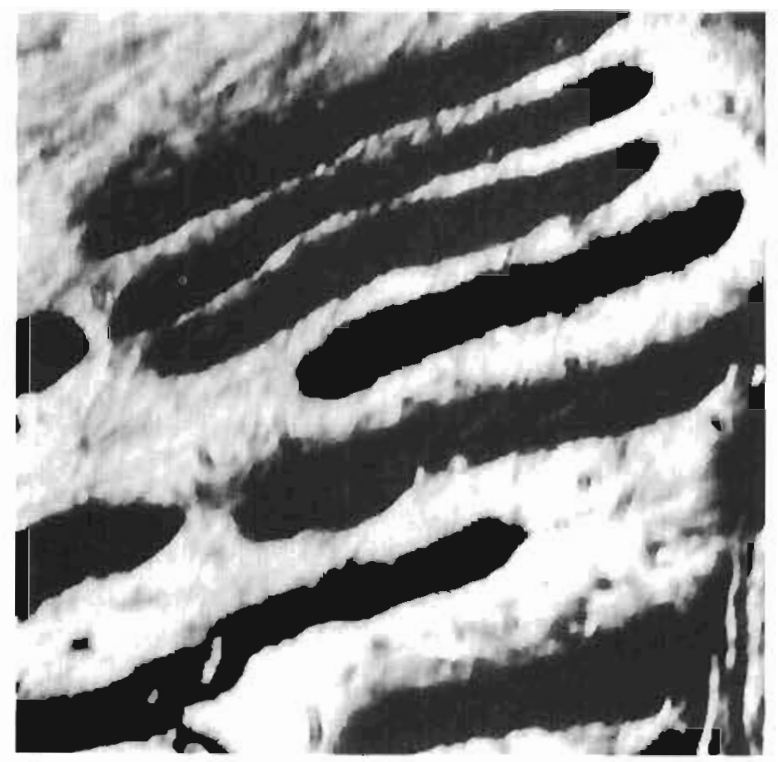

d. Sporinites in ulminite (JC3-5; mag. 625X).

Figure 34. Photonicrographs of Tertiary (Tyonek Formation) coals from Coal Creek (Beluga field), Johnson Creek, and Peters Hills area (Yentna field) showing huminite and liptinite macerals (oill immersion). Photographs by R.D. Merritt, 1982. 


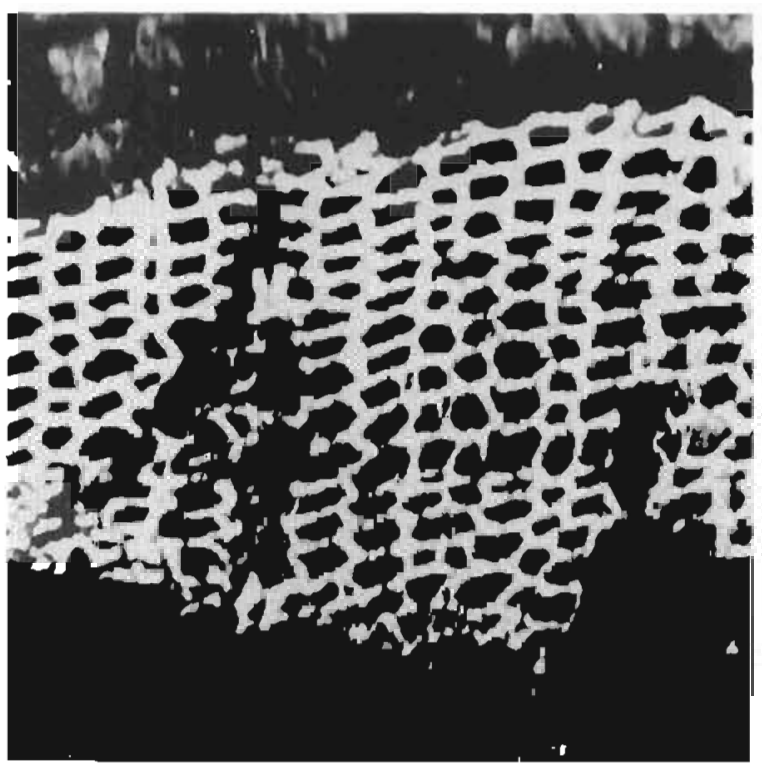

a. Fusintte (CC3-4; mag. 315x).

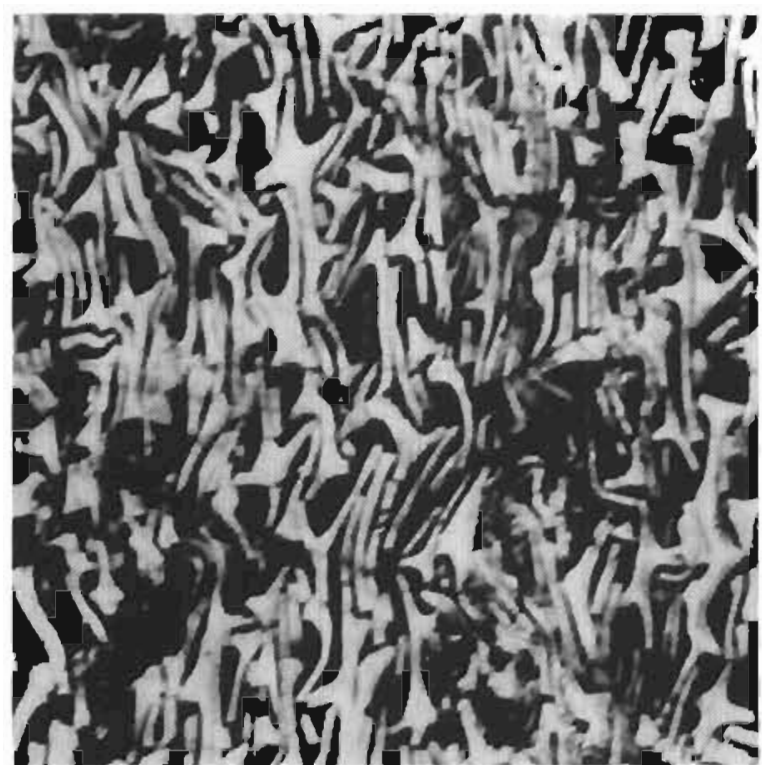

b. Fusinite with bogen structure (FM2-1; mag. 400X).

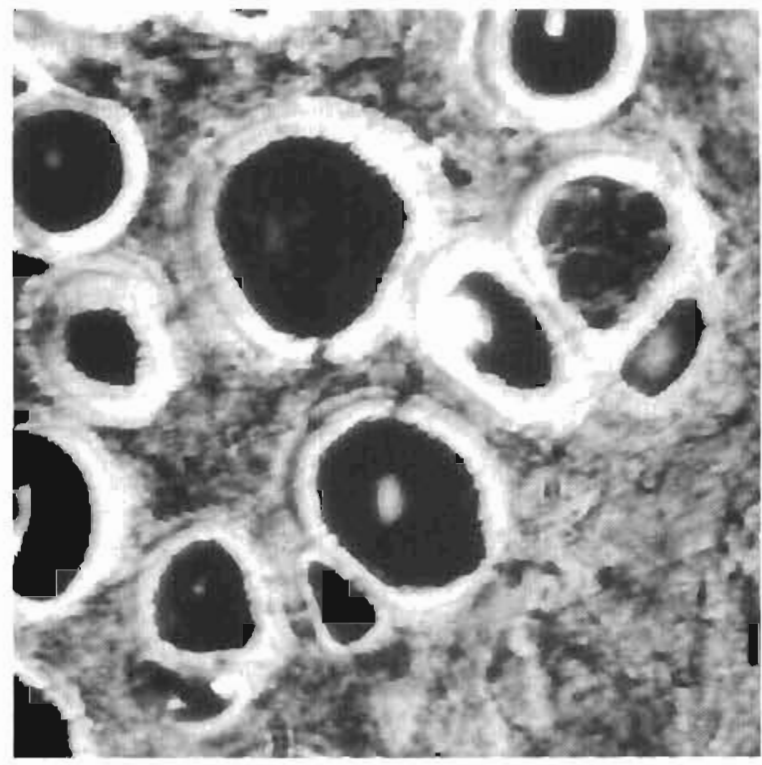

d. Fungal spores with mineral matter and inumic material (CC3-4p; mag. 625X).

Figure 35. Photomiciographs of Tertlary coals Erom Beshta Bay (Beluga Formation, Beluga field), Coal Creek (Tyonek Formation, Beluga field), and linirview Mountain (Tyonek Formation, Yentna field) showing predominant inertinite macerals (oil immersion). Photographs by R.D. Merritt, loga. 


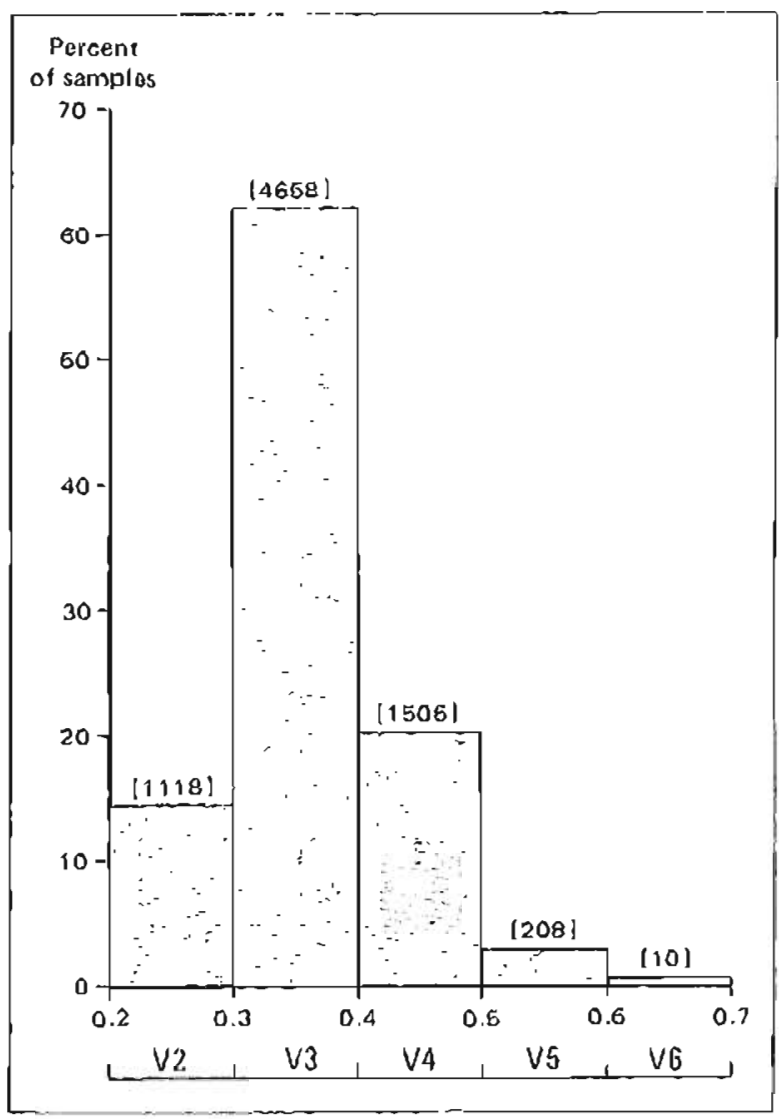

Figure 36. Histogram of vitrinte reflectance frequency (\%) as measured from ulminite macerals In coal sanples from the susitna lowland. Numbers tn brackets Indicate total number of grains measured at a given reflectance interva1; $V=$ reflectance class.

be monomaceralic (microlithotypes that contatn macerals of only one group), bimaceralic (with macerals of two groups), or trimaceralic (macerals of three groups). Table 8 summarizes the microlithotypes (Stach and others, 1975) that compose the macroscopic lithotypes: vitrain, clarain, durain, and fusain.

Coal samples from the Susitna lowland were not collected at vertical or lateral intervals close enough to permit detalled interpretation of facies changes within the caal seams; therefore, the main microlithotypes were very generally determined by selectively counting the maceral associations on the polished pellets and by interpreting the extensive maceral-composition data collected. Different groups of microlithotypes were subdivided into ind1vidual microlithotypes based on these maceral associations (Stach and others, 1975). Vitrite was the dominant microljithotype, with clarite that contains minor interbands of vitrinertite and trimacerite (duroclarite). Williams and Ross (1979) found similar maceral compositions and microlithotypes in Eocene bituminous coals from the Tulameen coalfleld of British Columbia. They also found that vitrite was the dominant microlithotype, with clarite that contained minor interbands of trimacerite (clarodurite) and durite. From their maceral deterninations, they proposed that the coal-forming peats developed In a forest moor environment in a poorly drained, low-1y.ng hasin next to an eroding upland in a warm, molst climate.

When Cohen (1973) relaced precursor peat types to eventual coal composition, he differentiated two major peat groups: (1) herbaceous peats, which produce massive, unlaminated, dul1 coal; and (2) tree-vegetation peats, which result in brighter, laminated coal. He Eound that herbaceous peats are lower 
Tabie 8. Sum mary of microlithotypes (from Stach and others, 1975, p. 110). a

Maceral

composition

(mineral-free)

$C o^{1}$
$T$
$V D$
$S$
$C U$
$R$
$A$
LD
SI
F
SC
ID
M

\begin{tabular}{ll} 
Microlithotype & $\begin{array}{l}\text { Macera)-group } \\
\text { composition } \\
\text { (mineral-frce) }\end{array}$ \\
\hline
\end{tabular}

$>95 \%$

$>95 \%$

$>95 \%$

$>95 \%$

$>95 \%$

$>95 \%$

$>95 \%$

$>95 \%$

$>95 \%$

$>95 \%$

$>95 \%$

$I+I D D$

V, I, E
$>5 \%$
Trimaceral
Monomaceral

(Collite)

(Telite) $^{a}$

Sporile

(Culite) $^{a}$

(Resite) $^{\mathrm{a}}$

A.lgite

Semátusite

Fusite

(Sclerotite) $^{\mathrm{a}}$

Inertodetrite

(Macroile) a

\section{Bimaceral}

Spoloclarite

Culicoclarile

(Resinoclarile) $^{\mathrm{R}}$
$V>95 \%$

Vitrite

$\mathrm{E}(\mathrm{L})>95 \% \quad$ Liplile

$1>95 \%$

Inertite
Microlithotype group

$V+1>95 \% \quad$ Vitrinertite $\mathrm{V}, \mathrm{I}$

Sporodurile (Cutricodurite)

(Resinodurite)

$I+E(L)>95 \% \quad$ Durite

I, E(L)
Duroclarice

Vitrinertoliptite

Clarodurite
$V>I, E(L)$
$E>I, V$

I $>$ V, E (L)
Trimacerite $V, I, E,(L)$

atemns in paroncheses nol now in use

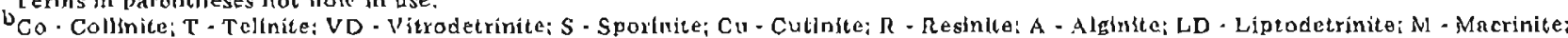
Sf - Semílusinile; F. Fusintle: Sc - Sclerolnlte; ID - Inertodetrinite; V - Vitrinite; F - Fusinite; L - Liptinite; l Inettinte; E - Exintte.

in prevesinites (cell fillings and secretions), fusinite (charcoal), and presclerotinites (fungal remains) but are higher in premicrinites (fine granular debris). Tree-vegetation peats, however, have a higher percentage of prevesinites, presclerotinites, and fusinite but a lower percentage of premictinitic materials. On the basis of this subdivision, most susitna lowland coals probably formed from tree-vegetation peats.

The determination of the paleoenvironment in which a coal-forming peat developed extends back to a classic paper by Hacquebard and Donaldson (1969), who described how flood plain and limnic environments in Nova Scotia were related to coal deposition during Carboniferous time (table 9). Hacquebard and Donaldson noted that coal-forming materials can accumulate in place, to form autochthonous coals, or can be transported to another region and accumulate to 
Table 9. Chief characteristics of anlochthonous and allochthonous couls (modified from Hacquebard and Donaldson, 1969).

Autochlhonous coals

a. Seams typically rest on underclay's

b. Occurrence of upright and rooted lossil trees

c. Minor llucluations in ash content both within and between seams

d. Wide distribution of seams and relatively uniform thickness of individual benches over large areas into dark gray or black shales

e. Excellent preservation of delicate plant organs (such as leaves) in rool shales

f. Presence of vicrain, clarain, durain, and Cusain, and excellent preservation of macerals.
Allochthonous coals

a. Common absence of underclays

b. Absence of upright trees

c. Relatively high percentages of ash

d. Pronounced variability in quality and thickness of coals, which grade boll laterally and verticaliy

e. Scarcity of plant remains in roofs of coal seains and in intervening shales

f. Consist predominantly of nore resistant macerals as corpocollinices and certain liptiniles and of inertinites with gbundant mineral inatter.

form allochthonous coals. Hypautochthonous coals originate malnly from plant debrys transported within the general area of its growth, whereas allochthonous coal seans form from peats deposiced as drfited vegetation--specifically, plant accumulations that drifted or were rafted into reglons other than those in which they originally grew.

Evidence indicates that most Susitra lowland coals formed in place, but some coals exhiblt characteriscics of each group. Upright and rooted fossil trees occur locally; most leaf impressions are completely intact and indicate no transport. Some Susttna lowland coals have a classic underclay.

Hacquebard and Donaldsor (1969) concluded that the most favorable locations for deposition of normal-banded autochthonous coals in a flood-plain environment ate interdistributary troughs and levee-flank depressions along river channels or areas associated with lacustrine sedimentation. Coal. seams as thick as 13.5 m are characteristic of the latter; compaction results in subsided, poorly drained areas favorable for formation of thick peat deposits (Hacquebard and Donaldson, 1969, p. 151). According to their model, distributíon and accumulation of chastic sediments in a flood-plain environment are controlled by the river's course and transporting power. Coarser sediments are deposited $1 n$ or next to the channel, patticularly as natural levees; finer grained sediments are carried into interdistributary areas by overbank Eloodwater. Interaction between fluvial sedimentation and peat deposition results in splits or digitations in seans and their eventual 'pinch-out'. Changes in flood-plain environments are accompanied by changes in vegetation and in the corresponding types and abundances of macerals preserved. Rapid subsidence and early burtal of peat leds result in excellent preservation of macerals.

At each sample location, Hacquebard and Donaldson (1969) subdivided the seam profile into petrographic intervals representing time-rock unjts. Each interval. Was bounded by clastic partings or by distinctive dull layers with a relacively widespread continuity and a characteristic microscopic composition. They expressed the aggregate thicknest; of individual microlithotypes as a percentage of an tnterval's total. thickness and plotted those percentages on a four-component 'facies' diagram ( $1 \mathrm{~g}$. 37). The vertices of the triangles represent those microlithotypes (or combinations thereof) characteristic to specific environments in the peat bog. 


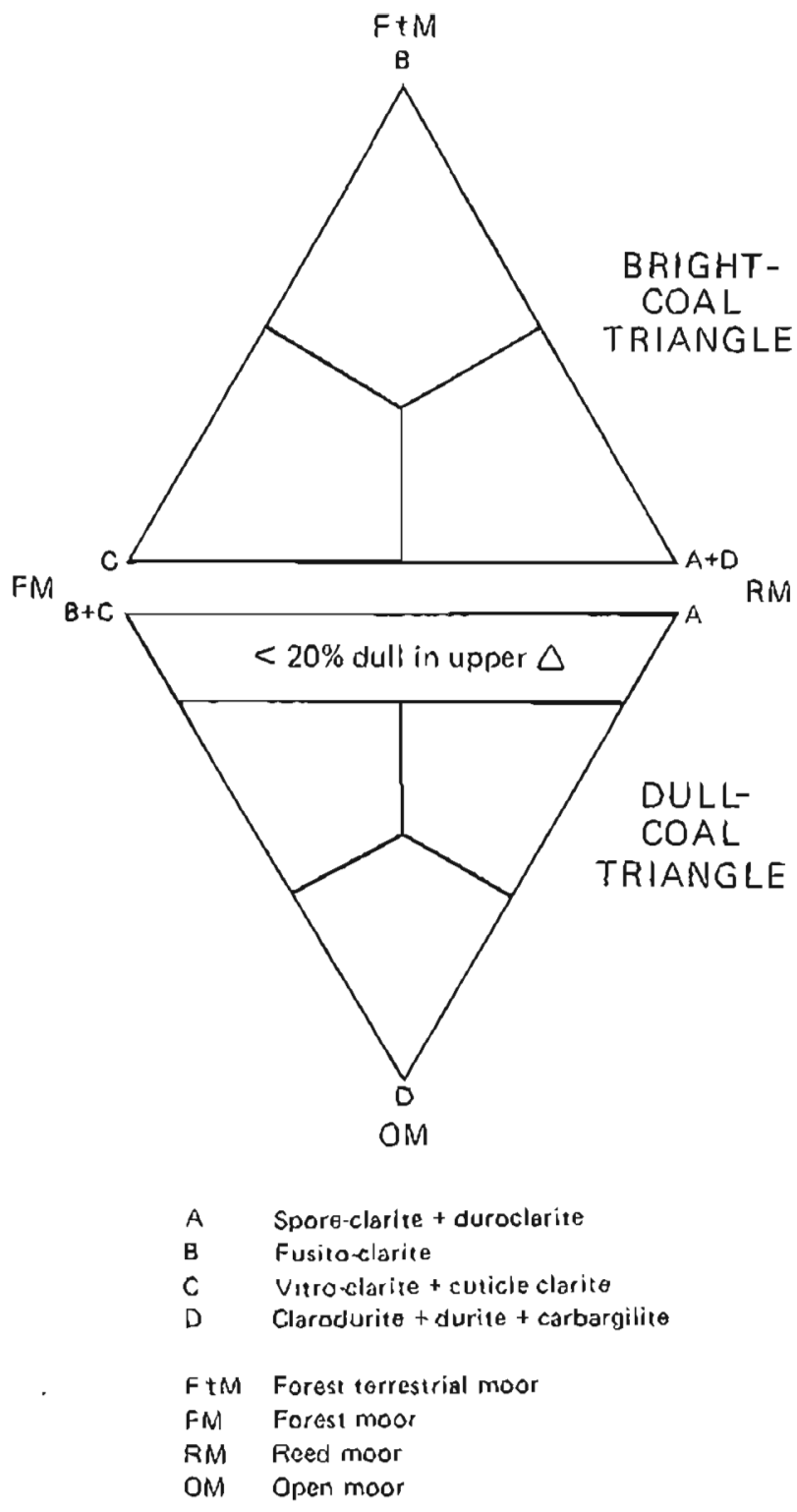

Figure 37. Four-component 'facies' diagram of individual microlithotypes in different petrographic intervals. ItM = relatively dry cunditions, an environment for the formation of fustto-clarite; $F M=$ an environment for deposition of vitrite and vitro-clarite; RM = an envilionment occupyíng transitional areas; of reed growth, deposition of spore-rich clarite; $O M=$ an envirorment for deposition of mainly subaquatic coals such as cannel and boghead and certain spore-rich clarite. Modifled from Hacquebard and Donaldson (1969).

They then assigned four diagnostic vegetation zones (Eollowing the procedure of Karmasin, 1952) to the corresponding vertices of the comblned triangles, to illustrate the paleoenvironmental origins of the microlithotypes. Forestmoor and reed-moor facies of the bright coal trlangle formed in the telmatic zone between high and low water levels (Osvald, 1937). Subaquatic (open moor) deposits of the lowest sector of the dull-coal trlangle formed in the limnic zone, and the two remaining sectors represent ilmno-telmatic deposits.

The microlithotypes most closely related to the susitna lowland coals are those in the lower left sector of the upper bright-coal triangle (sce f1g. 37); these contain vitrinite (or huminite) and little sporinite. The forest-moor environment, where vitrice and vitro-clarite are the predominant deposits, is the typical depositional. environment of most susitma lowland coals (especially Tyonek Formation coals) and of Tulameen fleld (British Columbia) coals. The vegetation types and the conditions under which these plant materials were preserved indicate that most Susitna lowland coals formed in a telmatic zone. 
Four major morphologic species of sedimentary pyrite or marcast.te occur in coals and their associated eediments: (1) framboidal pyrite, (2) euhedral grains, (3) coarse-grained masses ( $>25-\mu \mathrm{d} 1 \mathrm{am}$ ), which replace origiral plant material, and (4) coarse-grained platy masses or cleats that occupy joints. Disseminated euhedxal grains (usually 1 - to $10-\mu$ diam) and framboids ( $>25-\mu$ dlam) are primary-pyrite varieties; coarse-grained, massive, and replacement forms are secondary. Framboldal pyrite is a microsopic aggregate of pyrice grains in urique 'rasplerrylike' spheroldal clusters. The diameter of each microsphere varies from 0.25 to $1 \mathrm{H}$, and these microspheres compose spherules up to $250 \mathrm{H}$ ciam. Groups of Eramboidal spheres have been termed polyframboids (Caruccio and others, 1977). Pyrtte or marcasite also occurs ae microcrystalline rosettes (for example, as minute octahedrons).

Framboidal pyrite occurs in continental-fluvial, low-sulfur coals of the Kenai Group (for example, Capps Glacier area, Falrview Mountain, Peters Hills area, and Wolverine Creek sites). Until recently, the origin of framboidal pyrite seemed to ínvolve sulfur-reducing martne or brackish-water microblal urganisms, particularly bacteria. However, fine-grained pyrites were recently identlified in till (Stene, 1979), unconsolidated mud and anclent shale (Czurda and others, 1973), and freshwater sediments (De11, 1975). Organic matter and a reducing envilonment are prerequisites for framboidal pyrite formation, but, contrary to previous theory, sulfur-reducing bacteria such as Desulfovibrio desulfurlcans (Berner, 1969; Sweeney and Kaplan, 1973), which are restricted to marine and brackish waters, are probably not required. Williams and Keith (1963) found that roof rock of martne or brackish-water or 1 gin contains more sulfur than roof rock of freshwater orlgin, and, indeed, pyrite morphology and grain size are partly controlled by the geochemical regime in ancient peatswamp environments. However, because of the recent discovery of framboidal pyrite in a variety of sediments, paleoenvironmental interpretations cannot be based solely on their presence.

Most Susitna lowland coals contain <0.4 percent sulfur (table 10); thus, cleaning coal for sulfur would not generally be required. Coarse-grained, massive pyrite can be removed from coal by using the standard speciflc-gravity (sink-float) technique; organically combined pyrite, the most abundant type in Alaska coals, is difficultt to remove. High sulfate-sulfur content in a coal commonly indicates a weathered sample (for example, WC1-3 of rable 10).

Framboidal pyrite has been identified petrographically in certain Susitna lowland coals. Primary sedimentary sulfides rapidly oxidize to iron oxides and fexrous and ferric sulfates when exposed to air, but secondary pyrite is stable and is leached very slowly (Caruccio and others, 1977). Although framboidal pyrite is a major contributor to nost acid-mine-drainage problems in coal-mining regions (Caruccio, 1970), these conditions are not expected in the Susitna lowland because of the minor amount of pyritic sulfur and disseninated reactive framboidal pyrite. In addition, contamination of surface and ground water by the solution and release of chemically bound trace elements in the primary sulfide fraction should not occur, because the quantity of disseminated pyrite in coals of southcentral Alaska is minor. 
COAL QUALIII'

Coals of the Bcluga and west Yentna fields in Cook Inlet-Susitna lowland offer the greatest potential for near-term development. A revitalized coal, nining induscry could also develop in the Matanuska Valley. Locally, coals of the Matanuska field have been upgraded co anthracite by complex folding, faulting, and igneous activity. Coals of the central and eastern Yentna field have less potential, because they are typically $<2 \mathrm{~m}$ thick with a high ash content and low calorific value. The remaining coal deposits, in the Little susitna field, are thin, lenticular, have high ash content, and are marginally lignitic to subbituminous (Sanders, 1981).

Near-surface coals in the Beluga and Sterling Formatiors of the Kenai Peninsula are typically less mature than coils of the Tyonek Formation in the Susitna lowland; they are characterized by higher ash and volatile contents and $a$ lower fixed carbon content. These lignitfc to subbltumlnous coals are commonly < $\mathrm{m}$ thick, lenticular, du11, platy, and cleated with abundant prew served wood and bark tissues. However, coal beds as thick as $2 \mathrm{~m}$ occur, including one that was mined at liomer (Sanders, 1981). By contrast, numerous coal bedis within the Kenai Group (mostly within the Tyonek Formation) of the Susitna lowland are over 9 m thick.

Major coal deposits of the Susitna lowland are dominantly subbituminous $B$ or subbituminous $C$ coa] (app. B, table B-5). A thin, steeply dipping coal seam (WC2-9) on Wolverine Creek is ranked as high-volatile-B bituminous coal. Three thin coal seams at Fairview Mountain (FMl-13), Peters Hilis (PAl-34), and Talachulitna River (TR1-1; fig. 38) are ranked as subbituminous $A$ coal. Their apparent elevated rank may be due to weathering and oxidation effects.

Table 10. Tolal-sulfur and sulfur species of selected coal seans from Susitna l.olvland.

\begin{tabular}{|c|c|c|c|c|c|}
\hline Locale & $\begin{array}{l}\text { Sample } \cdot \text { seam } \\
\text { designation }\end{array}$ & Organic & $\begin{array}{l}\text { Sulfur species (\%) } \\
\text { Pyritic }\end{array}$ & Sulfate & $\begin{array}{l}\text { Total } \\
\text { sulfur (\%) }\end{array}$ \\
\hline \multirow[t]{4}{*}{ Capps Glacier area } & CG4-I & 0.23 & 0.01 & 0.04 & 0.28 \\
\hline & CG1.3 & - & . & 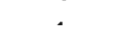 & 0.38 \\
\hline & CG4-4 & . & . & - & 0.01 \\
\hline & CG4:6 & - & . & . & 0.01 \\
\hline \multirow[t]{5}{*}{ Foirview Mountain } & FM]-2 & 0.14 & 0.01 & 0.06 & 0.21 \\
\hline & $F M 1-4$ & 0.24 & 0.01 & 0.02 & 0.27 \\
\hline & FM1-7 & 0.16 & 0.02 & 0.05 & 0.23 \\
\hline & FMI-10 & 0.19 & 0.01 & 0.01 & 0.20 \\
\hline & FMI-13 & 0.23 & 0.01 & 0.01 & 0.24 \\
\hline \multirow[t]{3}{*}{ Peter's Hills } & PA2-1 & - & - & . & 0.35 \\
\hline & PAB-1 & . & . & . & 0.50 \\
\hline & PA3-3 & . & . & - & 0.64 \\
\hline \multirow[t]{6}{*}{ Wolverine Creek } & WC1-3 & 0.22 & 0.05 & 0.39 & 0.66 \\
\hline & $W C 1-4$ & . & . & - & 0.67 \\
\hline & $W C 2-4$ & . & - & - & 0.70 \\
\hline & WC2.9 & - & . & . & 0.48 \\
\hline & WC2 $\cdot 10$ & 0.17 & 0.01 & 0.01 & 0.19 \\
\hline & WC2.14 & $\cdot$ & - & - & 0.42 \\
\hline
\end{tabular}




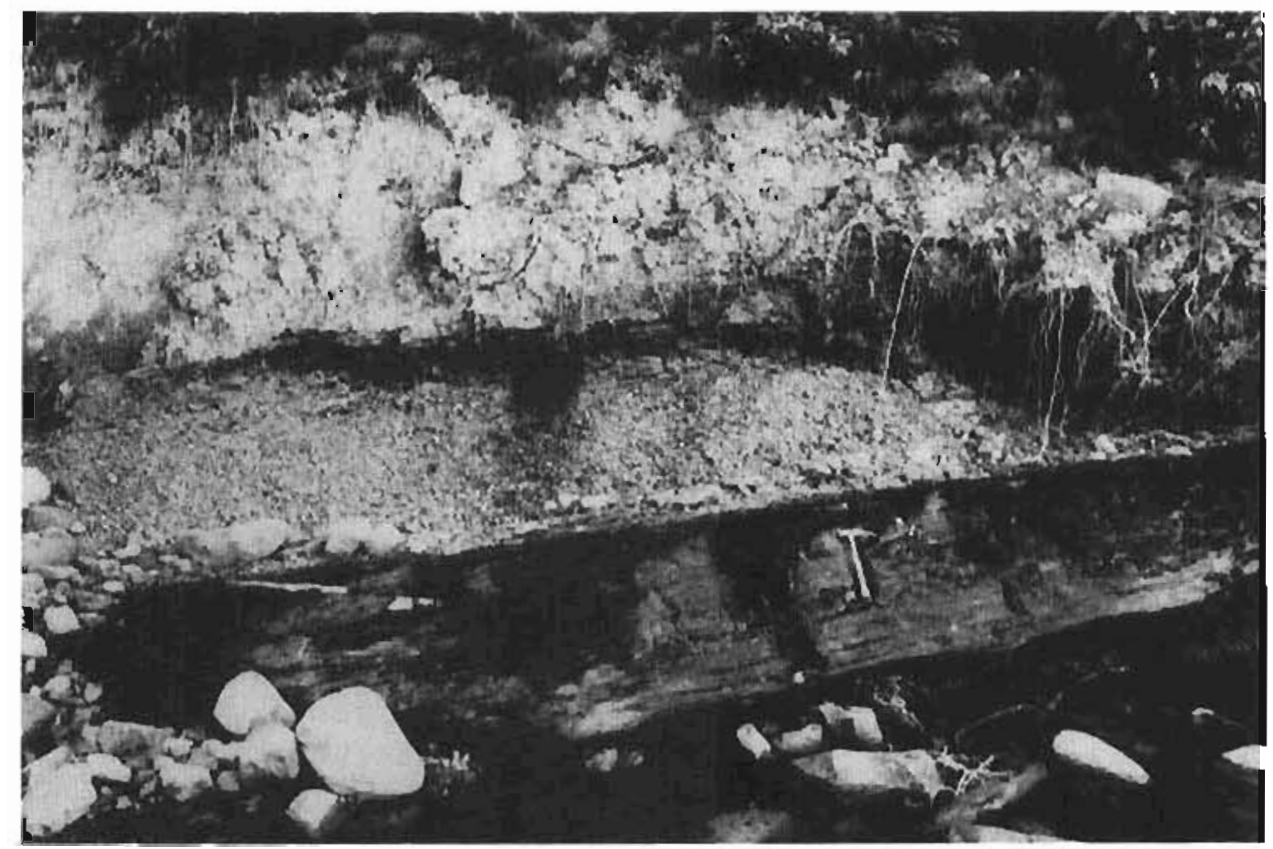

Figure 38. Coal seam (Tertiary, Tyonek Formation) exposed along the Talachulitna River in westcentral Susjitna lowland. Photograph by J.t. Sperber, 1981.

Coals are ranked according to the ASTM (1981) classification system. higher ranked coals are classiffed according to Eixed-carbon and volatilematcer contents as calculated on a dry, mineral-matter-free basis. Lower ranked coals with $<69$ percent carbon content, as those of the Susilna lowland, are classified according to their calorific value calculated on a moist, mineral-matter-free basis (app. B, tables B-5 and B-6).

Almost all published data on Susitna lowland coal qualtty (except those industry summaries developed from core samples) were derived from analyses of weathered outcrop samples. Data developed during the present study (summarhzed here and in app. B) do not meet ASTM criteria for rank evaluation, so conclusions from such analyses should be accepted with caution. Past studies in other areas, however, and a comparison of published data for unweathered samples (tables $1 \mathrm{l}-13$ ) with weathered outcrop saniples analyzed during this study, reveal that Btu and vitrinite-reflectance values differ only slightly between weathered Alaskan subbituminous coals and unweathered core samples. Stach and others (1975) reported on the studies of Chandra (1962), who measured and compared reflectances of naturally weathered outcrop samples and fresh, unoxidized samples obtained at greater depths, and found that there was no slgnificant difference in rank, as shown by reflectance measurements of the two sample groups. Although these Susitna lowland evaluations should be viewed as a measure of 'apparent rank,' they nevertheless indicate that lower mean annual temperatures and local. relatfve aridity reduce the effect of oxidation on Alaska coals.

The chlef attraction of mose Alaska coals is their extremely low sulfur content. Susttna lowland coals contain only 0.3 percent total sulfur (fig. 39; table B-7); the sulfur occurs matnly in organic form (table B-8). Their ash 


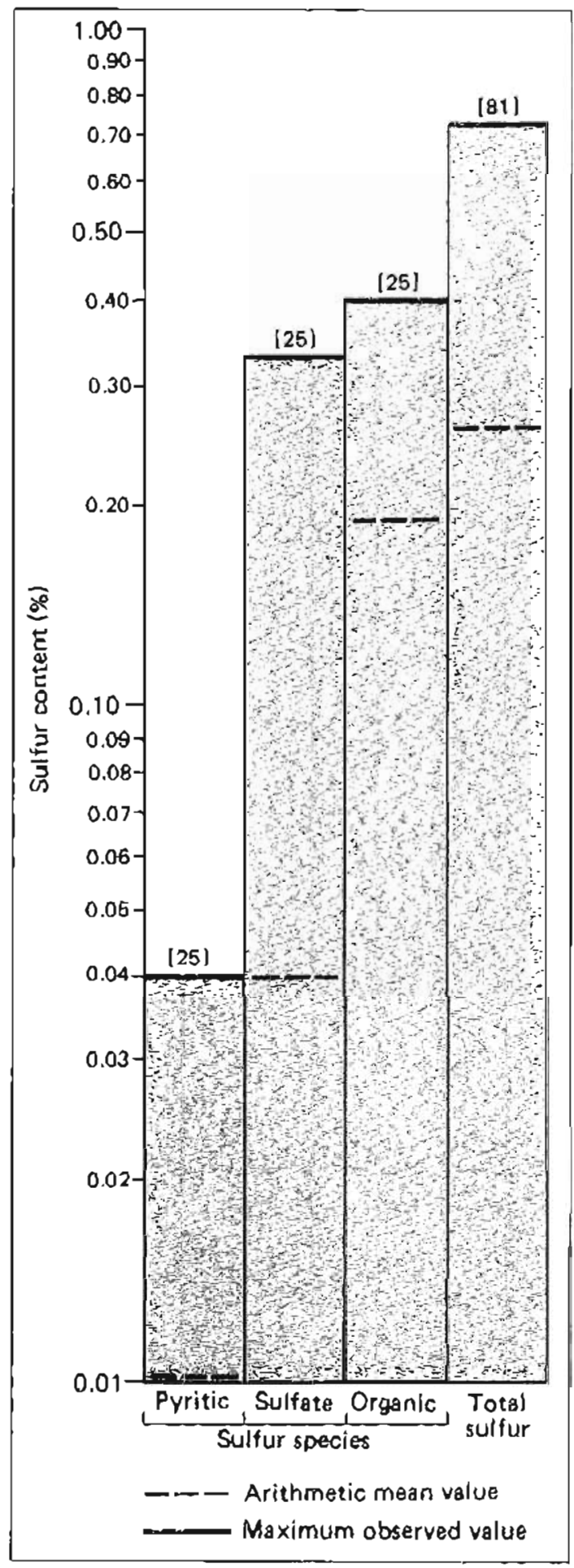

Figure 39. Histogram of maximum observed and axithmetic-mean values, percent total sulfur and sulfur species of analyzed Susitra lowland coal samples. Brackets = number of samples.
Table 11 . Average quality of Beluga field coals (fiom Palsein, 1976).

\begin{tabular}{|c|c|c|c|}
\hline & $\begin{array}{c}\text { As } \\
\text { received } \\
\end{array}$ & Dry & $\begin{array}{c}\text { Dried to } \\
10 \% \text { moisture } \\
\end{array}$ \\
\hline Moisture (\%) & 28 & - & 10 \\
\hline Ash (\%) & 10 & 13 & 12 \\
\hline Volatile mattey $(\%)$ & 32 & 44 & 40 \\
\hline Fixed carbon $(\%)$ & 30 & 43 & 38 \\
\hline Sulfur $(\%)$ & 0.15 & 0.2 & 0.2 \\
\hline \multicolumn{4}{|l|}{ Heating value } \\
\hline Btu/lb & 7,550 & 10,500 & 9,400 \\
\hline Calories/gm & 4,194 & 6,833 & 5,222 \\
\hline
\end{tabular}

T'able 12. Net coal thichnesses and assay dala for major seans, Chuilna River field, Alasko (from Ramsey, 1981).

\begin{tabular}{|c|c|c|c|c|}
\hline Seam & $\begin{array}{c}A v g \\
\text { net coal } \\
\text { thickness } \\
\text { (li) }\end{array}$ & $\begin{array}{l}\text { Ash } \\
(\%)\end{array}$ & $\begin{array}{c}\text { Sulfur } \\
(\%)\end{array}$ & $\begin{array}{c}\text { Heating } \\
\text { value } \\
\text { (Btu/lb) }\end{array}$ \\
\hline Blown & 28 & 10.13 & 0.33 & 7,845 \\
\hline Yellow & $5-15$ & 18.19 & 0.28 & 6,782 \\
\hline Green & 20 & 11.25 & 0.23 & 7,862 \\
\hline Blue & 28 & 7.34 & 0.16 & 8,216 \\
\hline Orange & 16 & 7.99 & 0.20 & 8,054 \\
\hline Red & 33 & 7.57 & 0.17 & 7,828 \\
\hline
\end{tabular}

Table 13. Coal-quality dota, Johnson Creek and Canyon Creele tracts (from Blumer, 1980). Average for various seams and locations, as-received basis.

Ash (\%)

$6-40$

Heating value (Btu)

$5,400 \cdot 9,450$

Sulfur (\%)

$0.1-0.2$

Moisture (\%) 
content varies, but it is low to moderate in some higher qualicy coals of the Tyonek Formation,

Table 14 shows barnes' (1966) analyses on several coals irom the be?ligaYentna regicr. Two cod-bearing sections from the Beluga fjeid (fig. 40) were measured and sampled in 1975 (Conwel1, 1977b). Elementál analyses (afp. B, tables B-S through B-14) revealed high levels of sodium, varadium, and barium, whereas elements such as mercury, antimony, uranium, and chorium, which tend to volatilize during combustion, occurred at low levels.

Table 14. Analyses of 16 coal samples from Belugu-Yentna region (modified from Barnes, 1966, p. C26-C27). Lisled as a runge for differenl parameters analyzed. Rank: Subbituminous $B$, subbiluminaus $C$, and lignite. Calculated moist mineral-free heating value $(B / W): 3,650 \cdot 9,800$.

\begin{tabular}{|c|c|c|c|c|c|c|}
\hline $\begin{array}{l}\text { Sample } \\
\text { condition }\end{array}$ & Moisture (花) & $\begin{array}{c}\text { Volatile } \\
\text { maiter (\%) }\end{array}$ & $\begin{array}{c}\text { Fixed } \\
\text { carbon (\%) }\end{array}$ & Ash (\%) & Sulfur $(\%)$ & $\begin{array}{c}\text { Heating } \\
\text { value (Btu) }\end{array}$ \\
\hline 1 & $19.7 \cdot 33.1$ & $30.1 \cdot 39.9$ & $26.4 \cdot 40.6$ & $2.0-16.8$ & $0.1 \cdot 0.4$ & $7,030-9,520$ \\
\hline 2 & - & $39.8 \cdot 56.1$ & $38.0-50.5$ & $2.7-22.2$ & $0.1 \cdot 0.6$ & $9,470-12,070$ \\
\hline 3 & - & $47.2 \cdot 57.9$ & $42.1 \cdot 52.8$ & - & $0.1 \cdot 0.6$ & $11,860-12,600$ \\
\hline
\end{tabular}

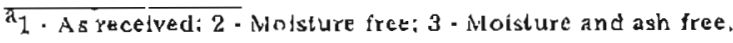

Table 15 presencs published results from proximate and ultimate analyses by Rao and Wolff (1981) of two coal seans: the Waterfall bed, from the Beluga field, and the Sunflower Creek bed, Erom the Yentna fleld, Rao and Wolff's (1981) vitrinite-reflectance data (table 16) show that the waterfall bed is subbituminous and the Sumflower Creek bed is Jignitic. The Sunflower Creek bed exhibits a very low ash and very low silica content; most inorganic matter consists of alumina, calcium, magnesium, and tron oxides (app. B, table B-l). Trace elements in Susicna lowland coals were generally similar co those found in other coals. Hovever, some Susitra lowland coals contained higher amounts of barium, manganese, and chromium, and some samples contained lower amounts of arsenic, zinc, boron, lead, and molybdenum (fig. 4l). Table B-13 (app. B) lists three-poínt ash fusitjutty on two composite coal sampless from the Beluga field (Corwell, lgiti). Deformational and melting temperatures reflected lowrank (subbituminous) coajs with moderate ash.

DGGS analyzed 66 coal samples from the Susitra lowland (Figs. 42 through 45; table 17) using a factor analysis based on proximate coal-quality data and heating values which deineated two significant iactors: (I) coals with higher fixed carbor have higher heating values and lower ash; and (2) coals containing higher volatile matter have lower ash. Moisture and sulfur were jnstgnificant factors which explained variances.

Scatter plors of paired proximate variables and heating values revealed similar trends (fig. 43). The high positive correlation fn figure $43 a$ sup ports the direct relatiorship between heating value and fiyed-carbon content: as the flxed-carbon content increased, so did the coal's rank (as measured by heating value). The high positive correlation in figure 43 b shows that heating values also varled directly with volatile-matrer content. The high negative correlation in figure $43 \mathrm{c}$ illustrates an inverse relationship between ash content and fixed carbon; coals with higher fixed-carbon content (higher rank) tended to have lower ash content. The high negative correlation in figure $43 \mathrm{~d}$ indicates that coals with higher volatile matter had lower ash content. These 


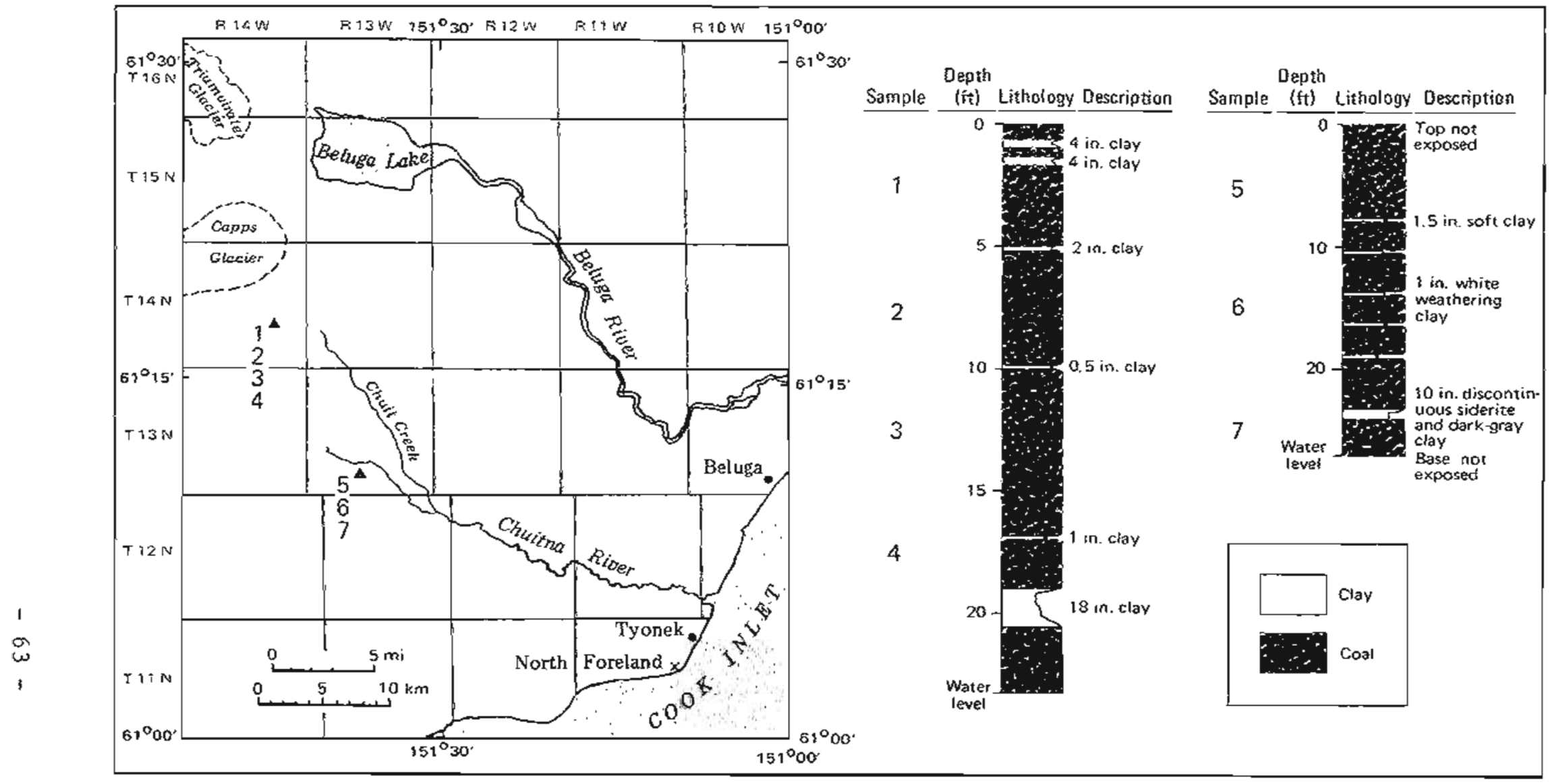

Figure 40. General location and lithologic descriptions of two measured coal-bearing sections (Tertiary, Tyonek formation) of the Beluga coalfield. Modified from Conwell (1977b).

Table 15. Proximate and ultimate analyses of rau coals, Waterfall and Sunflower Creek seams (from Rao and Wolff, $198 \mathrm{~J}$ ).

\begin{tabular}{|c|c|c|c|c|c|c|c|c|c|c|c|c|c|c|c|}
\hline $\begin{array}{l}\text { Coal field, } \\
\text { seam }\end{array}$ & $\begin{array}{c}\text { ASTM } \\
\text { rank }\end{array}$ & $\begin{array}{l}\text { Thickness, } \\
\text { meters } \\
\text { (ft) }\end{array}$ & Sample & Basis ${ }^{2}$ & $\begin{array}{c}\text { Moisture } \\
(\%)\end{array}$ & $\begin{array}{c}\text { Volatile } \\
\text { matter } \\
(\%)\end{array}$ & $\begin{array}{c}\text { Fixed } \\
\text { carbon } \\
(\%)\end{array}$ & $\begin{array}{l}\text { Ash } \\
(\%)\end{array}$ & $\begin{array}{l}\text { Heating } \\
\text { value } \\
\text { (Btu/lb) }\end{array}$ & $\begin{array}{c}\text { Carbon } \\
(\%)\end{array}$ & $\begin{array}{c}\text { Hydrogen } \\
(\%)\end{array}$ & $\begin{array}{c}\text { Nitrogen } \\
(\%)\end{array}$ & $\begin{array}{c}\text { Oxygen } \\
(\%)\end{array}$ & $\frac{\text { Sulfur }}{\text { Pyritic }}$ & $\frac{(\%)}{\text { Total }}$ \\
\hline Beluga, & Subbit C & 9.1 & VA-1IB & 1 & 23.65 & 35.20 & 33.34 & 7.81 & 8,327 & 47.98 & 6.25 & 0.54 & 37.28 & 0.01 & 0.24 \\
\hline \multirow{2}{*}{ Waterfal } & & $(30)$ & & 2 & - & 46.10 & 43.67 & 10.23 & 20,907 & 62.84 & 4.71 & 0.71 & 21.33 & 0.01 & 0.18 \\
\hline & & & & 3 & . & 51.35 & 48.65 & - & 12,151 & 70.01 & 5.25 & 0.79 & 23.74 & 0.01 & 0.21 \\
\hline Yentna, & Lignite & 3.0 & UA-115 & 1 & 29.80 & 38.26 & 28.61 & 3.33 & 7,943 & 45.20 & 6.76 & 0.53 & 44.07 & 0.01 & 0.11 \\
\hline Sunflover & & $(10)$ & & 2 & - & 54.50 & 40.76 & 4.74 & 11,315 & 64.39 & 4.87 & 0.75 & 25.10 & 0.01 & 0.15 \\
\hline (uppex) & & & & 3 & - & 57.21 & 42,79 & - & 11,879 & 67.59 & 5.11 & 0.79 & 26.35 & 0.01 & 0.56 \\
\hline Yentna, & Lignite & 3.0 & $\mathrm{UA} \cdot 116$ & 1 & 29.86 & 39.29 & 28.43 & .2 .42 & 8,017 & 45.48 & 6.89 & 0.49 & 44.67 & 0.01 & 0.05 \\
\hline Sunflower & & $(10)$ & & 2 & - & 56.02 & 40.54 & 3.44 & 11,429 & 64.84 & 5.06 & 0.70 & 25.89 & 0.01 & 0.07 \\
\hline (lower) & & & & 3 & - & 58.02 & 41.98 & - & 11,837 & 67.16 & 5.24 & 0.73 & 26.79 & 0.01 & 0.08 \\
\hline
\end{tabular}

a - equilibrium-bed moisture; 2 - moisture free: 3 - moisture and ash free. 
Table 16. Vitrinite-reflectance data, Waterfall and Sunflower Creek seams (from Rao ond Wolff. i98I).

\begin{tabular}{|c|c|c|c|c|c|c|}
\hline \multirow[b]{2}{*}{ Coal field/seam } & \multirow[b]{2}{*}{ Sample } & \multirow{2}{*}{$\begin{array}{c}\text { Mean naximum } \\
\text { reflectance } \\
\text { (Romax) }\end{array}$} & \multicolumn{2}{|c|}{ Frequency } & \multicolumn{2}{|c|}{ Histogram } \\
\hline & & & V1 & V2 & V 3 & \\
\hline Beluga/Water [all & UA.113 & 0.25 & 3 & 86 & 11 & U \\
\hline Yentna/Sunflowel (upper) & UA.115 & 0.33 & 0 & 28 & 66 & \\
\hline Yentna/Sunflower (lower) & $\mathrm{UA} \cdot 116$ & 0.22 & 46 & 37 & 14 & \\
\hline
\end{tabular}

relationships are expected for a group of samples which exhibit a narrow range of rank variance, as do most Susitna lowland subbituminous coals. A cluster analysis of Susitna lowland coals (fig. 44) disclosed that coals with slmilar characteristics formed distinct clusters. Coals from specific localities (Canyon Creek, Beluga River, Saturday Creek) formed fairly close clusters. see table B-14 for a proximate analysis; of each sample listed in figure 44.

Results of ultimate-analysis of selected coals from scattered localities in the Susitna lowland (table 18) were cypical. of subbituminous coals and indicated these coals to be low-rank because of low carbon content and high oxygen content. Lignitic, subbituminous, and low-rank bituminous coals generally contain 5 or 6 percent hydrogen; hydrogen decreases to 3 or 4 percent in high-

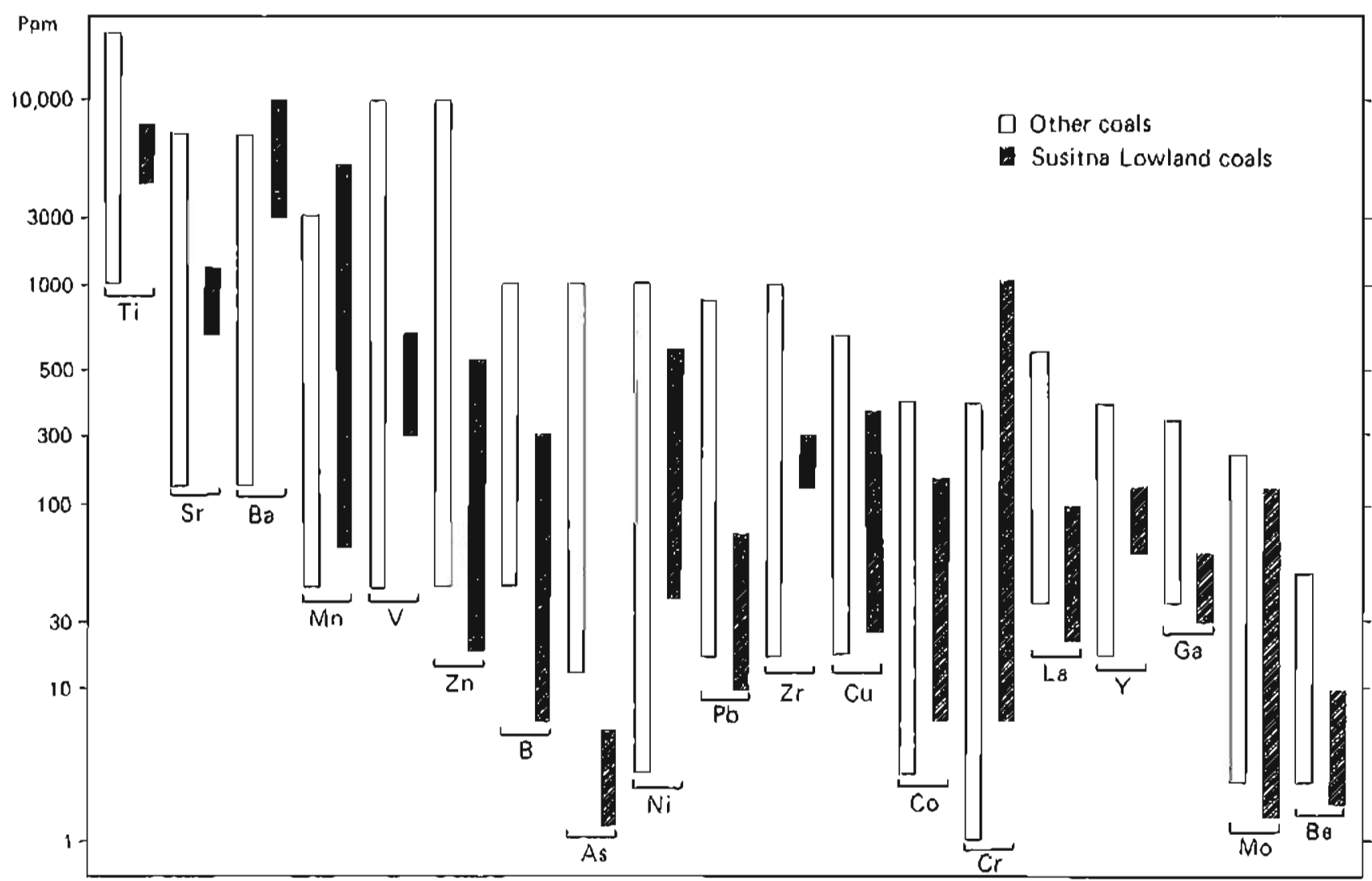

Pigure 41. Range of trace elements in raw coal ashes commonly found in other coals compared to range of those in Sustena lowland coals. Data for other coals from Mason (1966, p. 242); Susitna lowland coal data from present study, Corwell (1977b), and Rao and Wolff (1981). 


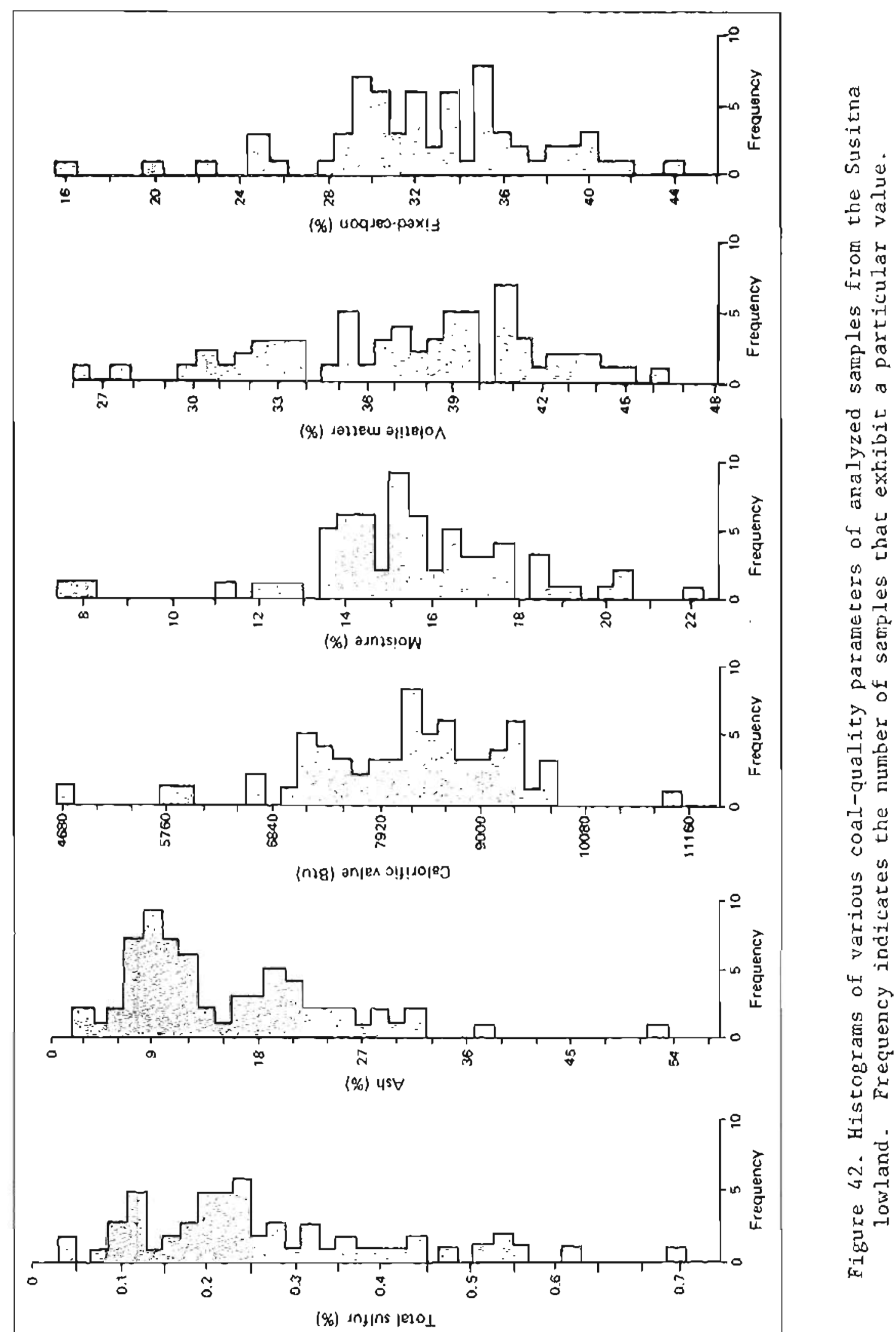




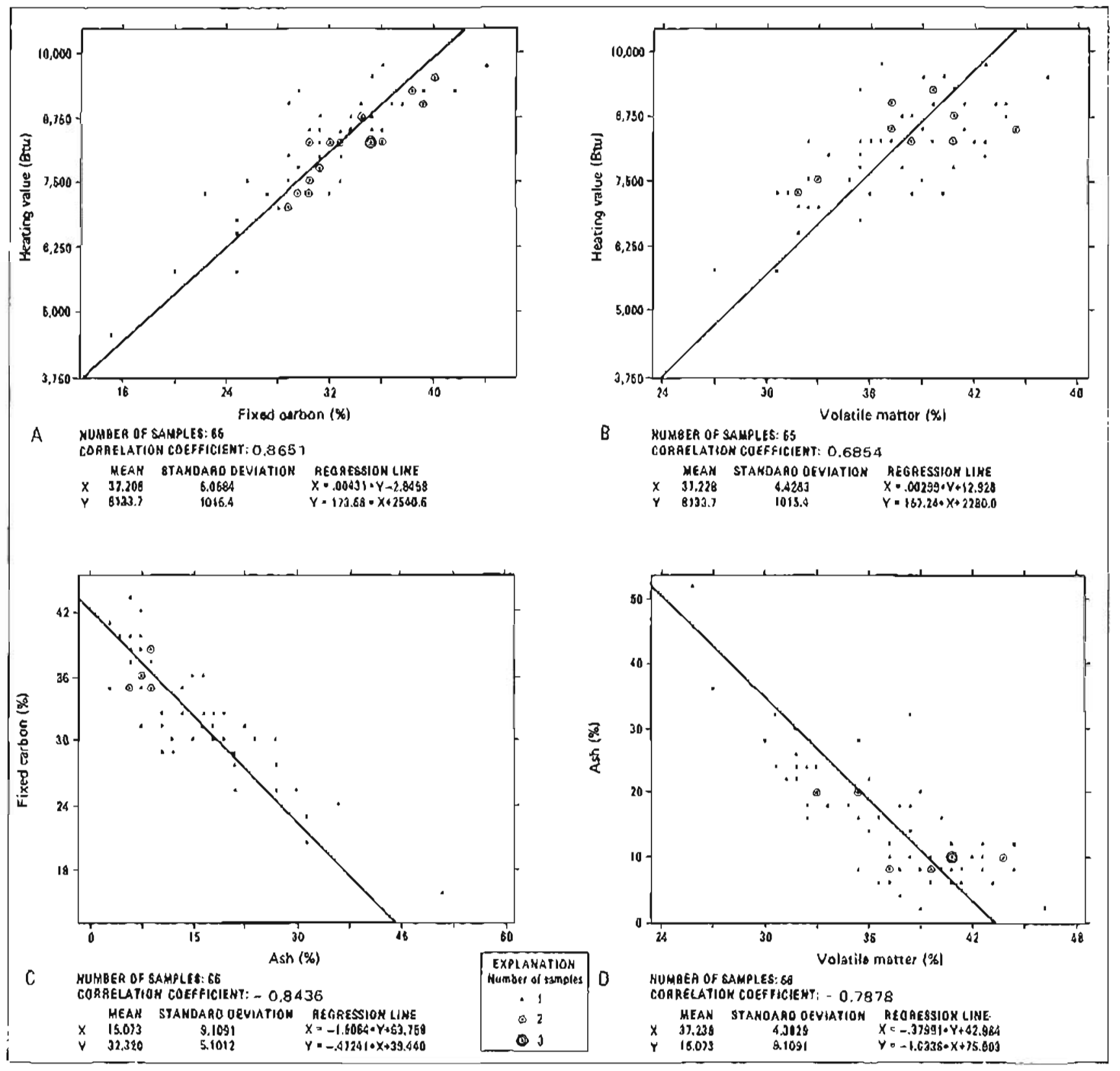

Ftgure 43. Scattex plots with regression lines of paired proximate variables for analyzed coal samples from the Susitna lowland.

rank bituminous and anthracitic coals. Highest amounts of sulfur and mitrogen usually occur in bituminous coals, decreasing in both lower and higher rank coals. Within the broad spectrum of coal rank, ash contents are typically independent of various rank indicators and reflect variations in the quantity of mineral matter initially deposited in a peat swamp.

Inorganic matter in Susttna lowland coals consiseed mainly of silica, alumina, and calcium oxides, with lesser amounts of ixon and magnesium oxides (fig. 45). Silica content was highest in Falrview Mountain coal ash and lowest in some Chultna River coal ash. Alumina content was higher in certain Canyon 


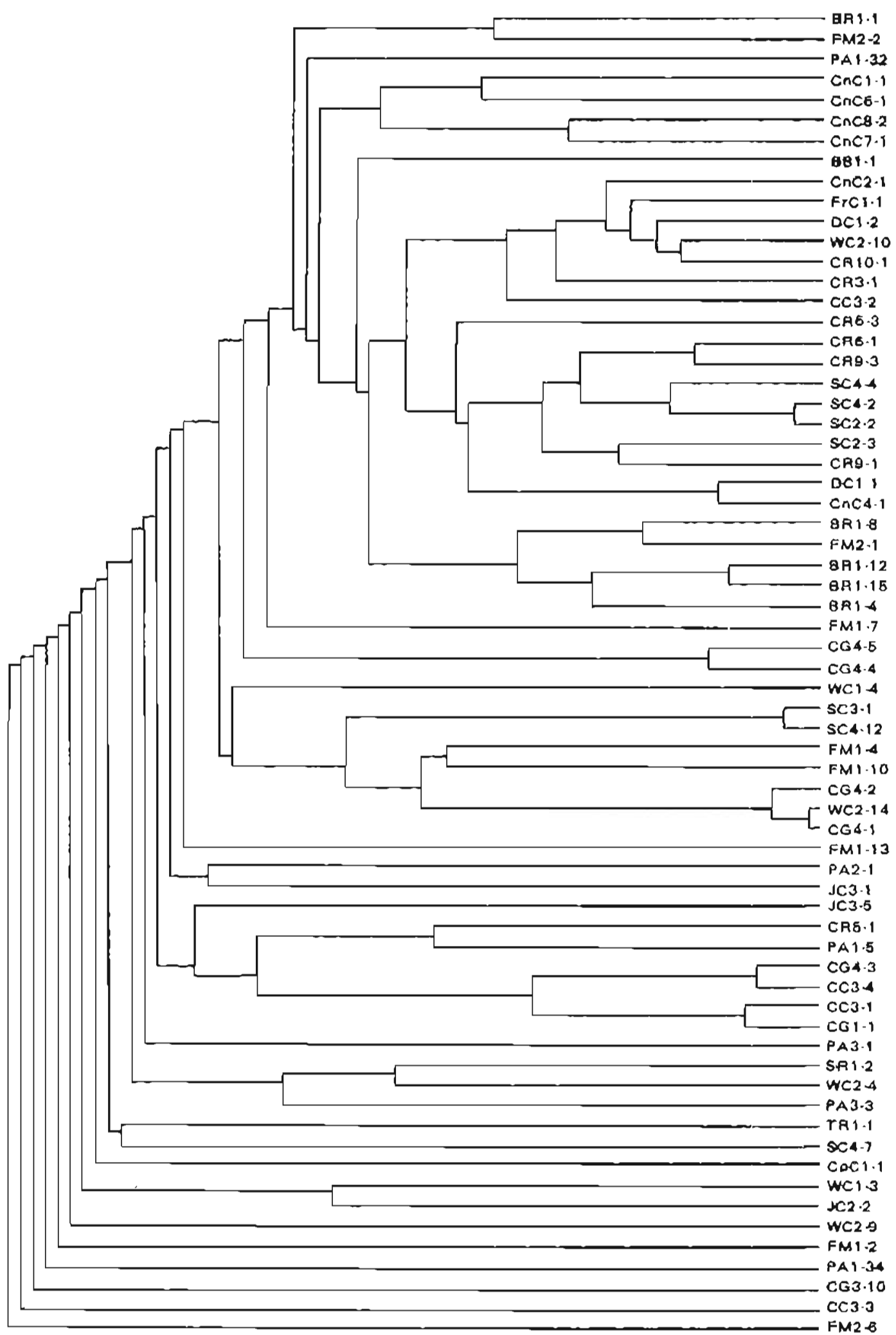

Figure 44, Cluster analysts based on proximate data, total sulfur, and heating values for analyzed coal samples from the Susitna lowland. 


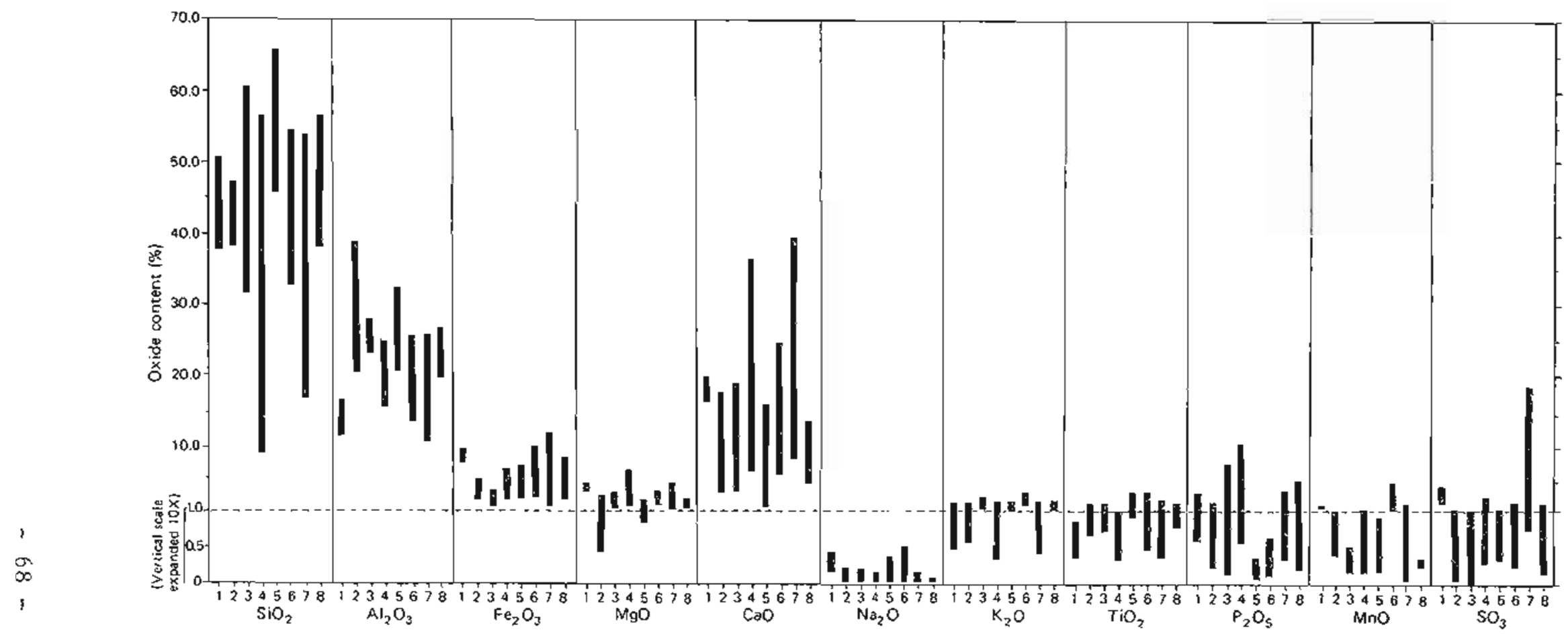

Figure 45. Range of major-oxide concentrations in raw-coal ash from eight localities in the Susitna lowland. Sample locality; 1 = Beluga River; 2 = Canyon Cxeek; 3 = Capps Glacier; 4 = Chuitna River; 5 = Fairview Hountain; 6 = Peters Hills; 7 = Saturday Creek; anc $8=$ wolverine Creek.

Table 17. Summary of range and mean values and coal-quality characteristics of 66 samples fromt the Susitra Lowlond.

\begin{tabular}{|c|c|c|c|c|c|c|c|}
\hline r & & Moisture (\%) & $\begin{array}{l}\text { Volatile } \\
\text { matter }(\%)\end{array}$ & $\begin{array}{c}\text { Fixed } \\
\text { carbon }(\%)\end{array}$ & Sulfur $(\%)$ & Asth $(\%)$ & $\begin{array}{l}\text { Heating } \\
\text { value, } \mathrm{Btu}\end{array}$ \\
\hline \multirow{3}{*}{ Range } & 1 & $7.3-21.9$ & $25.9-461$ & $15.1-43.7$ & $0.01-0.73$ & $2.4-51.7$ & $4,570-10,960$ \\
\hline & 2 & - & 27.9 .55 .1 & $16.4-50.9$ & $001-0.91$ & $2.8-55.7$ & $4,930-13,400$ \\
\hline & 3 & - & 45.6 .63 .2 & $36.8-54.4$ & $0.01-1.03$ & $\cdot$ & $10,480-15,540$ \\
\hline \multirow{3}{*}{ Mean } & 1 & 15.4 & 37.2 & 32.3 & 0.26 & 15.1 & 8,163 \\
\hline & 2 & - & 44.1 & 38.3 & 0.31 & 17.7 & 9,680 \\
\hline & 3 & - & 53.7 & 46.3 & 0.39 & $\cdot$ & 11,766 \\
\hline
\end{tabular}

1 - As received: 2 - moisture Ine: 3 - Moist are and ash free 
Table 18. Resull of ullimate analyses, in percent, of selecled coals from the Susilna Lowland.

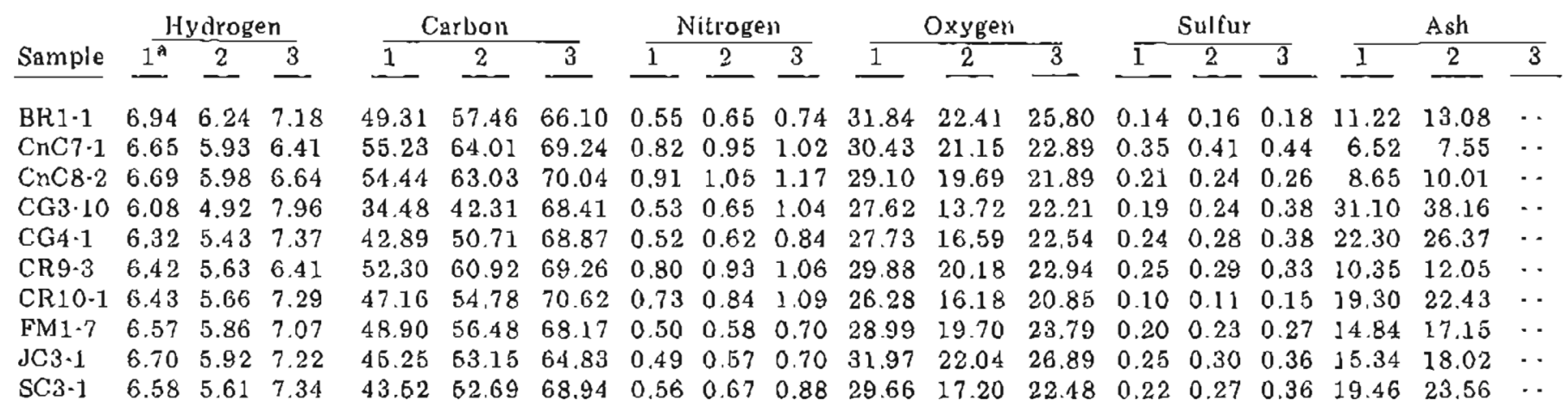

1- As received: 2 - moisture free: 9 - molsture and ash iree.

Creek coal ash; Chuicna River and Saturday Creek coal ash tended toward higher calcium-oxide content. Saturday Creek coals also exhibited higher stilfate content. The content of other major oxides was fairly constint at all sites.

In summary, coals of the Tyonek Formation appear to be of higher quality than those of the Beluga and Sterling Formations in the Susitna lowland. This conclusion is supported by results of current coal-characterization research. However, coals from all formations studied were primarily subbituminous with moderate to high motsture, extremely low sulfur, and varlable ash.

\section{COAL RESOURCES AND RESERVES}

Estimates of Alaska's coal resources and reserves are crude because of insuffictent subsurface information over broad areas. Definitive data are needed if the USBM and USGS coal-resource classification system ( $\mathrm{fig}$. 46) is to be used. However, until additional driling and seismic data become available, resource estimates for coalfields in Alaska cannot be precise.

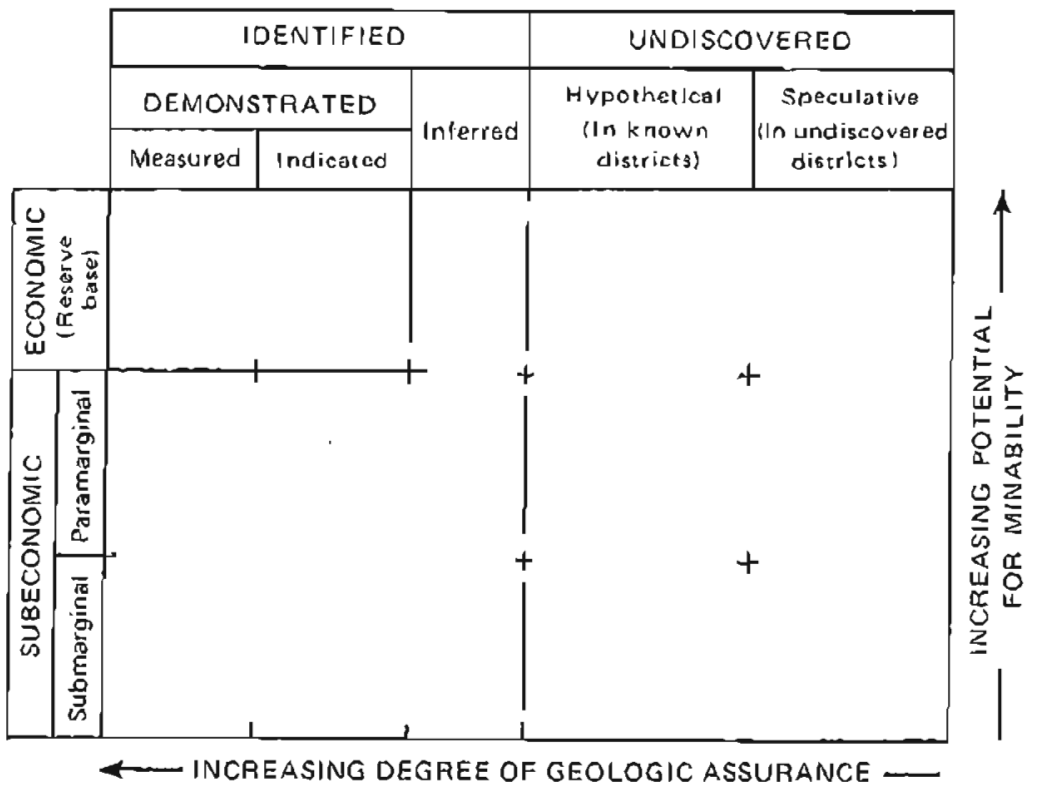

Figure 46. Coal resource classification system of U.S. Bureau of Mines and U.S. Geological Survey. Modified from U.S. Geological Survey (1976). 
The Cook Inlet-Susitna lowland area represents the second largest coal resource base in Alaska-surpassed only by the deposits iri northern Alaska-and may have the greatest porential of any single unieveloped coal 'property' in che United States. large areas of the Susitna lowland most likely contain shol.10w, strippable coal deposits (fig. 47). Sheet 3 is a preliminary interpretatlve coal-potential map of the Sustcna lowland based on the coal-bearing outcrop pattern and goologic structure in the region. Many areas judged to have high potential for coal development have already been leased (fig. 48). however, other large areas in the Susiuna lowland probably contain siguificant but poorly defined or undiscovered conl resources.

T'he total coal resource in the Cook Inlet-Sustena lowland coal province is estimated at 1.5 trillion tons, 11 billion tons of which are identified resources (McConkey and others, 1977; Sanders, 1981). Estimated identified resources in the Beluga-Yentna region are 10 blllion tons; estimated hypothetiral resources are 30 bilition tons. Swift and others (1980) have estimated that at least 750 million tons are economically mirable in about 50,000 ac $(20,250 \mathrm{hec})$ in the Capps and Chuitna districts.

McGee and $0^{\prime}$ Conror (1975) estimated total resources at 29 billion tons in the Beluga and Yentna coalfields, 24 billion tons on the Kenai Peninsula, and 1.3 trillion tons beneath cook inlet (Lo a depth of $3,050 \mathrm{ml}$ ). They speculate that 53.2 billion tons of coal lit beneath Cook In let in beds thicker than $6 \mathrm{~m}$. Barnes (1967) estimated the identified regources of several major coal seams of the Beluga field (table 19) but did not project the cool beds far from outcrops in valley walls.

Several major coal seams occur on the west of the Susitna lowland in the Yencna coalfield. At Fairview Mountaln, six coal beds <2. m thick crop out; a 4.5-m-thlck bed is exposed on Camp Creek, a 17-m-thick bed on Sunflower Creek, and several beds $44.5 \mathrm{~m}$ thick on Johnson Creek (E1g. 49), Nakochna River, and Canyon Creek (sheet 1). At least five seans ranging from 3 to 12 m thick occur on the Johnson Creek tract, and flve minable seams from 3 to $14 \mathrm{~m}$ thick occur or the Canyon Creek tract. At one locality on Canyori Creek, four separate seams form $19 \mathrm{~m}$ of coal in a 23.5-n-thick interval. On the Johnson Creek and Canyon Creek tracts, an Identifited resource has been estimated to exceed 500 milition tolls to a depth of $76 \mathrm{~m}$ (Blumer, 1981); these tracts are currently leased by Mobil 011 Corporation (sce fig. 48).

In the centril and eastern Yentna hasin, Nelson and Reed (1978) infericd a coal resource of at least 64 million tons. Sanders (1981) stated that coals In this area occur in the upper $2,440 \mathrm{~m}$. The near-surface coals are $<1.8 \mathrm{~m}$ thick (fig. 50), but placer miners in the Dutch Hills and Peters Hills areas have made use of them for years.

In 1916, Cache Creek Dredging Company began operating the Short Creek Coal Mine on a Yentna kiver tributary to supply power for its dredge (Naske and Triplehorn, 1980). The Peters Creek coal beds crop out next to the Parks Highway and Alaska Rallroad. Portland General Electric drilled in this region in 1976 (table 20).

Coal deposits of the Susitna lowland have been delineated by private industry drilling programs since 1967, but most data are still proprietary. 


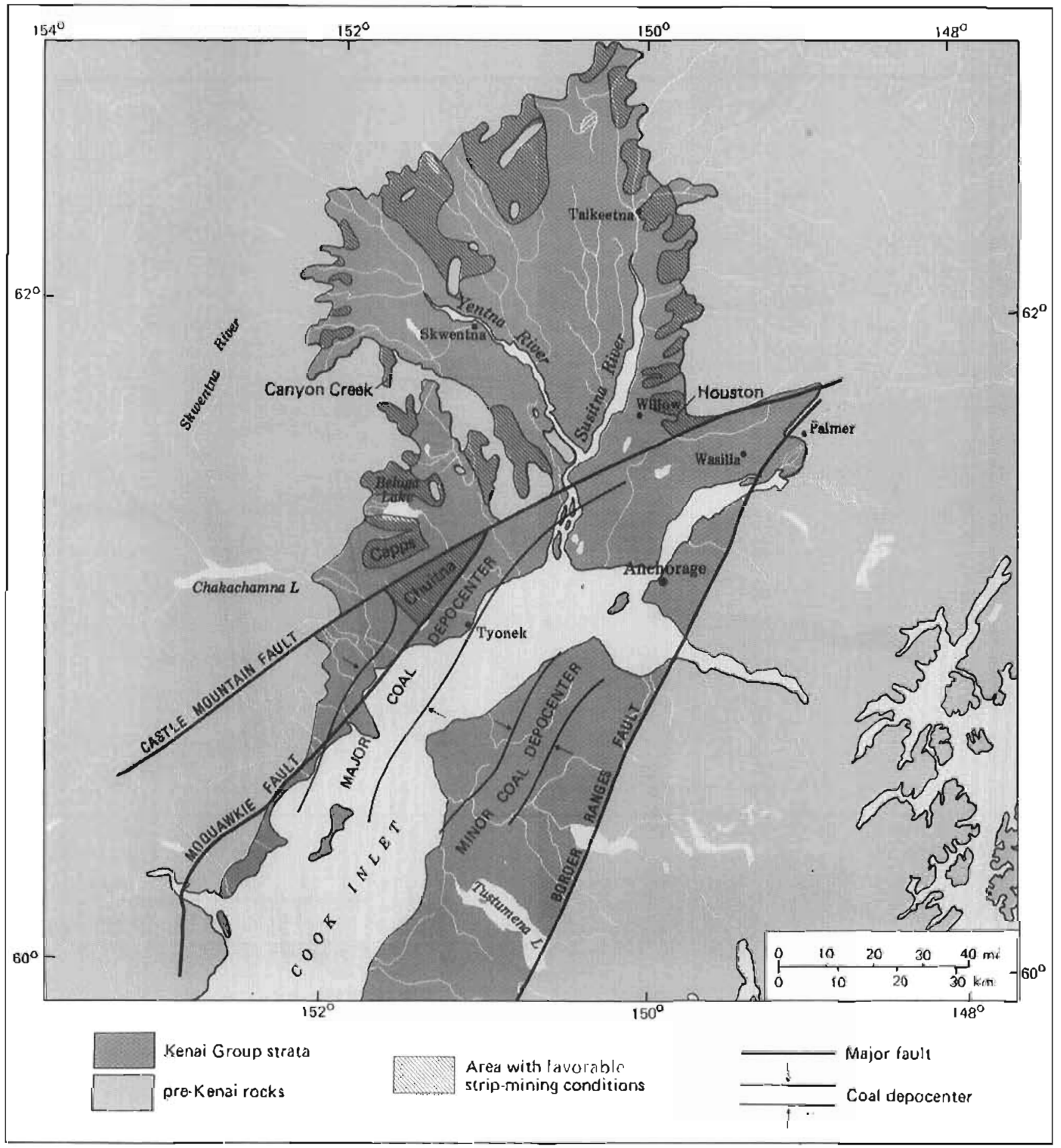

Figure 47. Areas of the Susitna low aid with favorable strip-mining conditions. Modilied from Ramsey ( $198 \mathrm{lb}$ ).

Current coal lessees have identified several mining sites tr the Chuitna districe northeast and southwest of the Chuttna River. The combined tonnage of surface-mireable low-sulfur coal heis by Placer U.S. Inc. and Dlamond Alaska Coal Company is approxinately b bllion tons, with a waste to shore ton of coal ratio of $<6$ bank:ycl ${ }^{3}$ (table 21 ). 


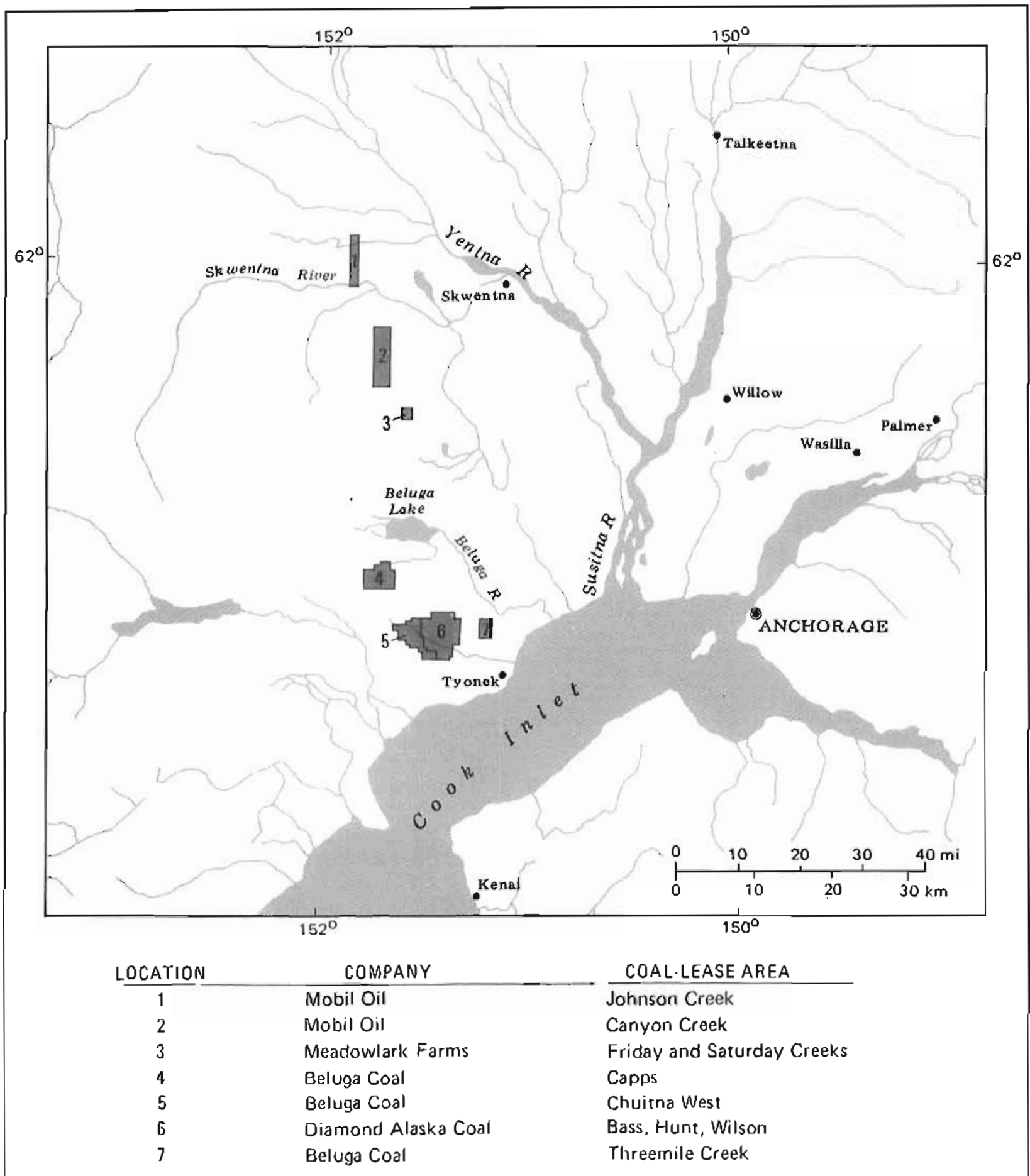

Figure 48. Locations of major coal leases 10 the Susitna lowland.

Both companies conducted engineering-Eeastbility studies for mining 1 to 15 militon ton/yr. Placer U.S. Inc. developed and sampled about 500 million tons of mineable reserves in four potential mine sites: one at Capps, two at Chuitna, and one at Threemilc (table 2l). The Capps deposit, which occupies a locallzed ll- to $13-\mathrm{km}^{2}$ coal basin, contains two major seams, the Capps and 
Tuble 19. Fistimated idontified coal resources for several major scams in the Boluga wer (form Barnes. $1966)$.

\begin{tabular}{lcc}
\multicolumn{1}{c}{ Seam } & $\begin{array}{c}\text { Average } \\
\text { thickness }(\mathrm{m})\end{array}$ & $\begin{array}{c}\text { Resources } \\
\text { (million tons) }\end{array}$ \\
\cline { 3 - 4 } $\begin{array}{l}\text { Chuitma bed } \\
\text { Capps bed }\end{array}$ & 15 & -243 \\
Lower Chuilna bed & -6 & 366 \\
Canyon bed & 7 & 69 \\
Drill Creek bed & 20 & 66 \\
Beluga bed & 9 & 6.1 \\
& & 12
\end{tabular}

the Waccriall beds, which average 5.2 and 9.2 m thick, respectively. The stripping ratio is estimated at 4:1 to 5:1 (Patsch, 1976).

Six seanit constitute most of the resources within the Chuitna River coalFleld (table 21). Study of ouccrops alone the river and a detailed drilling program helped identify the seams. Although the number of mineable seams is simjlar east and west of the chuitna kiver, the coal beds have not been correlated. The Brown coal is Barnes' Chuitna seam; the Red, Orange, and Blue seams were delineated mostly by drilling within a planned open-pit axea by Btamond Alaska Coal Company.

Mose favorable mining prospects within the Susitna lowland occur where thick coal beds of the Tyonek Formition ar: within $100 \mathrm{~m}$ of the iurface. Most coal beds over $6 \mathrm{~m}$ thick are restricted to lile Tyonek Formation, in which over

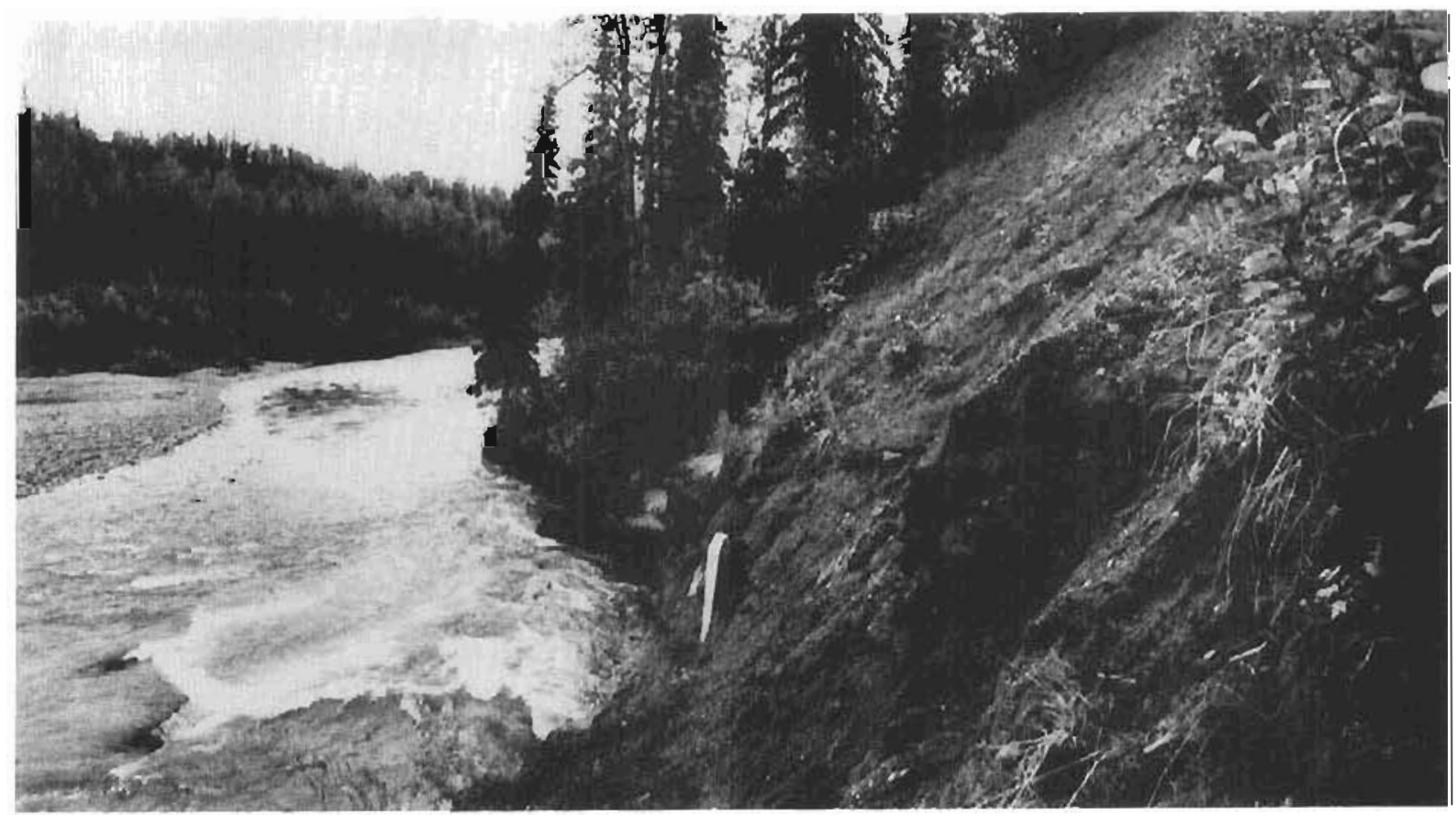

Figure 49. A coal bed in the Tyonek Formation exposed along loinson Creek, western margin of the Susitna lowland. Photograph by J.l. Sperber, 1981. 


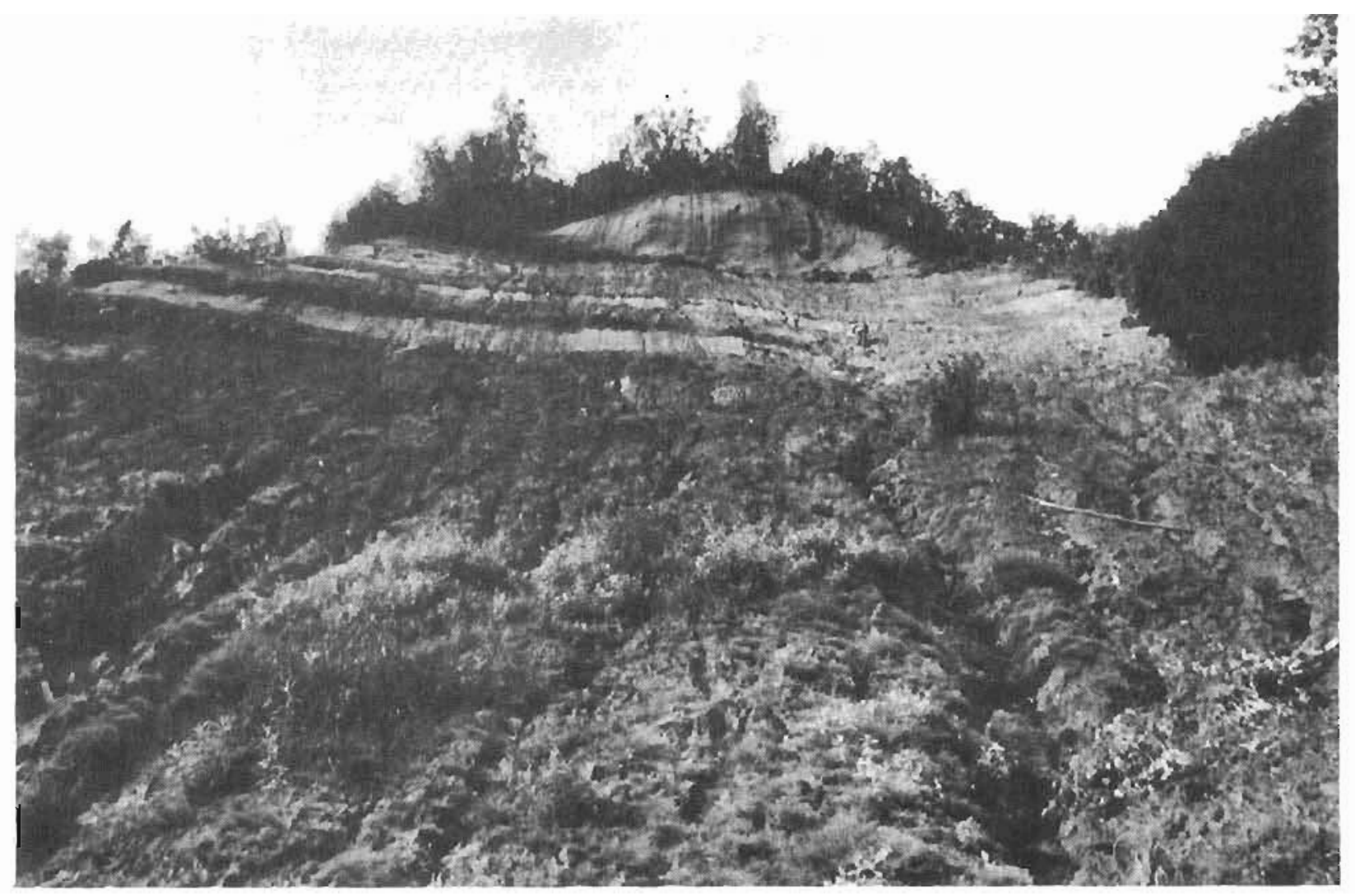

Figure 50. View of coal-bearing saction along Short Creek, l'eters Hills area, as seen looking up from creek-bed level. (east Yentna field, Tyonek Formation). Photograph by J.L. Sperber, 1981.

Table 20. Pelers Creck arll dala."

\begin{tabular}{|c|c|c|c|c|c|c|c|c|c|c|}
\hline \multirow[b]{3}{*}{ Drillhole } & \multirow{2}{*}{\multicolumn{4}{|c|}{ Location }} & \multirow{3}{*}{$\begin{array}{l}\text { Total } \\
\text { depth } \\
\text { (ft) }\end{array}$} & \multirow[b]{3}{*}{$\begin{array}{l}\text { Elevation (fl). } \\
\text { top to botiom }\end{array}$} & \multirow[b]{3}{*}{ No. seams } & \multicolumn{3}{|c|}{ Coals } \\
\hline & & & & & & & & $\operatorname{Max}$ & & \\
\hline & $\begin{array}{l}\text { Quarter- } \\
\text { quarter }\end{array}$ & Section & Township & Range & & & & $\begin{array}{l}\text { thickness } \\
\text { (ft.) }\end{array}$ & $\begin{array}{l}\text { Depth } \\
(\mathrm{ft})\end{array}$ & $\begin{array}{l}\text { Filevalion } \\
\text { (fi) }\end{array}$ \\
\hline $\mathrm{L}$ & SE/ $/ / E^{\prime} / 1 / 4$ & 11 & $26 N$ & $8 \mathrm{~W}$ & 510 & $1,150 \cdot 640$ & 2 & 1.5 & $127-175$ & 1.023 .975 \\
\hline 2 & $S W / 4 W^{1 / 4}$ & 2 & $26 \mathrm{~N}$ & $8 W$ & 440 & $1.165 \cdot 725$ & 0 & - & . & - \\
\hline 3 & $N W^{1 / 4} N^{1 / 4}$ & 3 & $26 \mathrm{~N}$ & $8 W$ & 460 & $1,225-765$ & 2 & 2.0 & $326-385$ & $899-840$ \\
\hline $4^{b}$ & & & & & & & & & & \\
\hline 5 & $S W^{1 / 4} W^{1 / 4}$ & 11 & $26 \mathrm{~N}$ & $B W$ & 240 & $1,120 \cdot 880$ & 2 & 4.0 & 64.87 & $1,056 \cdot 1,033$ \\
\hline 6 & SE $1 / 4 S W / 4$ & 11 & $26 \mathrm{~N}$ & $8 \mathrm{~W}$ & 510 & $1,194-684$ & 2 & 1.0 & $361-381$ & 8.3.3-til :3 \\
\hline 7 & NW/4SEM/4 & 11 & $26 \mathrm{~N}$ & $8 \mathrm{~W}$ & 465 & $1.192-727$ & 2 & 2.5 & $323-340$ & $S(i 9-6 i 52$ \\
\hline$\dot{\phi}$ & $N W 1 / 4 S W / 4$ & 12 & $26 \mathrm{~N}$ & $8 W$ & 510 & $1,157-647$ & 7 & $2 . \overline{5}$ & 405 & 752 \\
\hline 9 & $\mathrm{SE}^{2} / 4 \mathrm{SW}^{1 / 4}$ & 2 & $26 \mathrm{~N}$ & $8 \mathrm{~W}$ & 375 & $1,175 \cdot 800$ & 2 & 3.0 & $101-353$ & $1,074-1222$ \\
\hline 10 & $S E^{1 / 4 N W}$ & 10 & $26 \mathrm{~N}$ & $8 \mathrm{~W}$ & 300 & $1.340-1.040$ & 0 & $\cdot$ & v & \\
\hline [] & $\mathrm{SW}^{2} / 4 \mathrm{SE}^{1 / 4}$ & 3 & $26 \mathrm{~N}$ & $8 W$ & 360 & $1,200-840$ & 1 & 4.0 & 64 & 1.136 \\
\hline 12 & $\mathrm{NW}^{1 / 4} \mathrm{SE}^{1 / 4}$ & 13 & $26 \mathrm{~N}$ & $8 \mathrm{~W}$ & 300 & $1.020-720$ & 0 & - & & - \\
\hline 13 & $\mathrm{NE}^{1 / 4 \mathrm{NE}^{1 / 4}}$ & 18 & $26 \mathrm{~N}$ & $7 \mathrm{~W}$ & 105 & 1.000595 & 0 & - & - & - \\
\hline
\end{tabular}

dSummarized from Porland General Electric insornutiem. Bedrilled as DH 6 . 
Table 21. Minable reserves, Beluga coal field (madified fram Rao and Wolff, 1981). Estimates provided by Beluga Coal Company.

\begin{tabular}{|c|c|}
\hline Basin & Coal beds \\
\hline Threemile Creek & $\begin{array}{l}\text { Contains } 22 \text { partially exposed, } \\
\text { steep)y dipping } 10 \text {-ft-thick } \\
\text { seams (avg). }\end{array}$ \\
\hline Chuitna River & $\begin{array}{l}\text { Six seams, two minable } \\
\text { outcropping coal beds (one } \\
\text { over } 40 \mathrm{ft} \text { thick). }\end{array}$ \\
\hline Capps & $\begin{array}{l}\text { Two seams exposed in the } \\
\text { Tyonek Formation -..the upper } \\
\text { Capps bed averages } 17 \mathrm{ft} \\
\text { thick, the lower Waterfall } \\
\text { bed (Capps bed of Barnes, } \\
1966 \text { ) has an average min- } \\
\text { able thickness of } 30 \mathrm{ft} \text { but } \\
\text { ranges from } 20-50 \mathrm{ft} \text {. The } \\
\text { interburden thickness varies } \\
\text { from } 80-280 \mathrm{ft} \text {. }\end{array}$ \\
\hline
\end{tabular}

\author{
Location \\ 6 mi from Cook Inlet
}

$17 \mathrm{mi}$ from Cook Inlet

26 mi from Cook Inlet
Estimate of minable reserves

60 million tons; $9: 1$ stripping ratio.

200 million tons of near surface reserves on west side of river.

200 million tons in Capps and Waterfall seams at 5:1 stripping ratio.

100 separate beds have been distinguished in a single well log (see fig. 18). O11-well logs 1ridicate that the West Foreland, Hemlock Conglomerate and Beluga Formations contain several thick coal beds at depth. Coal beds of the Sterling Formation are generally $<2.5 \mathrm{~m}$ thick. Strata of the sterling Formation crop out in the northern part of the Yentna fleld and on the western coast of the southern Kenal Peninsula, where as many as 37 coal beds are exposed, Other major coal deposits occur in the Chickaloon Formation of the Matanuska fleld. The Chickaloon Fornation is up to $915 \mathrm{~m}$ thick in the Matanuska field and has at least 30 different coal beds in the upper $460 \mathrm{~m}$ (Conwell and others, 1982).

\section{OVERBURDEN CFARACTER}

In the absence of active mining operations, the character of overburden of the Kenal Group coals in the Susltna lowland has received little attention. oualitative and quantitative overburden characterization is slgniflcant for several reasons, not the least of which are the enforcement provistons of the Surface Mining Control and Reclamation Act of 1977. The sultab1lity of overburden for use as a subsoil medlum during mine site reclametion is of prime importance. The breakup of unweathered rock materlals and their placement Into the zone of active leaching also creates a potential for deleterious effects on regional surface- and ground-water quality.

The character of overburden varies--as does the quality of Individual coal seams withir a given basin--and is dependent on its depositional environment. Overburden mineralogy is determined by Eh and $\mathrm{pH}$ conditions, temperature, and salinity of the deposicional regime.

Pyrite, gypsum, dolomite, and clay minerals within the overburden affect the ground-water chemistry; pyritic and argillaceous materials have the great- 
est potential for producing highly nineralized ground water. Sulfate $\left(\mathrm{SO}_{4}{ }^{-}\right.$) and sodium ( $\mathrm{Na}$ ) concentrations are of particular concern (Groenewold and ${ }^{4}$ others, 1981). Because of the relatively low contene of pyritic sulfur in the coal overburden of southcentral Alaska, weathering of sulfides and subsequent dissolutior of sulfates should not significantly impact regional ground-water quality (Merritt, 1982). Nelsor. (1981) reported relatively high dissolved iron concentrations $(0.41$ to $6.2 \mathrm{mg} / \mathrm{L})$ and color that ranges from 5 to 200 turbidity unfts in ground-water samples from five wells between Grante Point and the Beluga River. One sample from a well $14.5 \mathrm{~km}$ nertheast of Granfte Point contalned $0.150 \mathrm{mg} / \mathrm{L}$ arsenic. Toward the eastern VicArthur Flats near cook Inlet, ground and surface waters are heavily stained with iron and contaln reddish-silme deposits, probably formed by lron-fixing bacteria.

Certain elements can sometimes be correlated with a depositional environment: boron, bromine, chlorine, sodium, strontium, phosphorus, nickel, cobalt, vanadium, chromium, uranium, copper, sulfur, carbon, and oxygen are the most common paleoenvironmental indicators, in addition to organic matter (Reineck and Singh, 1975). Bailey (1981) found that relatively higher contents of copper, chromium, titanium, potassium, silicon, and arsenic are associated with fluvial coals; zinc, tron, calcium, pyritic sulfur, and sulfate sulfur are generaliy more abundant in coals formed in marine-influenced depositional systems.

Overburden is composed of Inorganic sedimentary rocks, thin, unmineable coal stringers (rider seams) at the mine site, and unconsolidated profile and bedrock strata. Unconsolidated sequences include solls (topsoli and subsoll horizons), other alluvium and colluvium, and glacial deposits; erratics and well-fidurated layers (particularly plastic-clay zones) pose minor problems during minfing. Bedrock strata are composed of relatively soft materials such as shale and weathered rock and hard materials (conglomerate, sandstone, siltstone, and linestone). Burn material (baked rock, scoria, or porcellanite) forms varicolored gleys when weathered (Fig. 51), and these gleys and melting permafrost may cause slope-jnstab1lity problems (Schmol1 and Yehle, 1978).

Designing a spectfic program to handle overburden on a mine site may be complicated by rapid lateral or vertical changes in Lithology (Merritt, 1983). Where such relationships exist, as in the Susitna lowland, lithologic units may be grouped into several major textural classes or rock types:

- Bight-textured materlals, predominantly sandstone and sandy siltstone

- Medium-tertured materlals, predominantly stltstone

- Heavy-textured materials, predominantly claystone

Coal stringers (including bone coal), rider seams, carbonaceous shales

Major coal seams

Interburden (clay or sand partings, including bentonites and tonsteins, in thick coal seams or between coal seams)

Porcellanite or scorla (baked rock above a burned coal)

- Giaclal deposits

Stream deposits (alluvium)

Sheetwash colluvium or eolian deposits. 


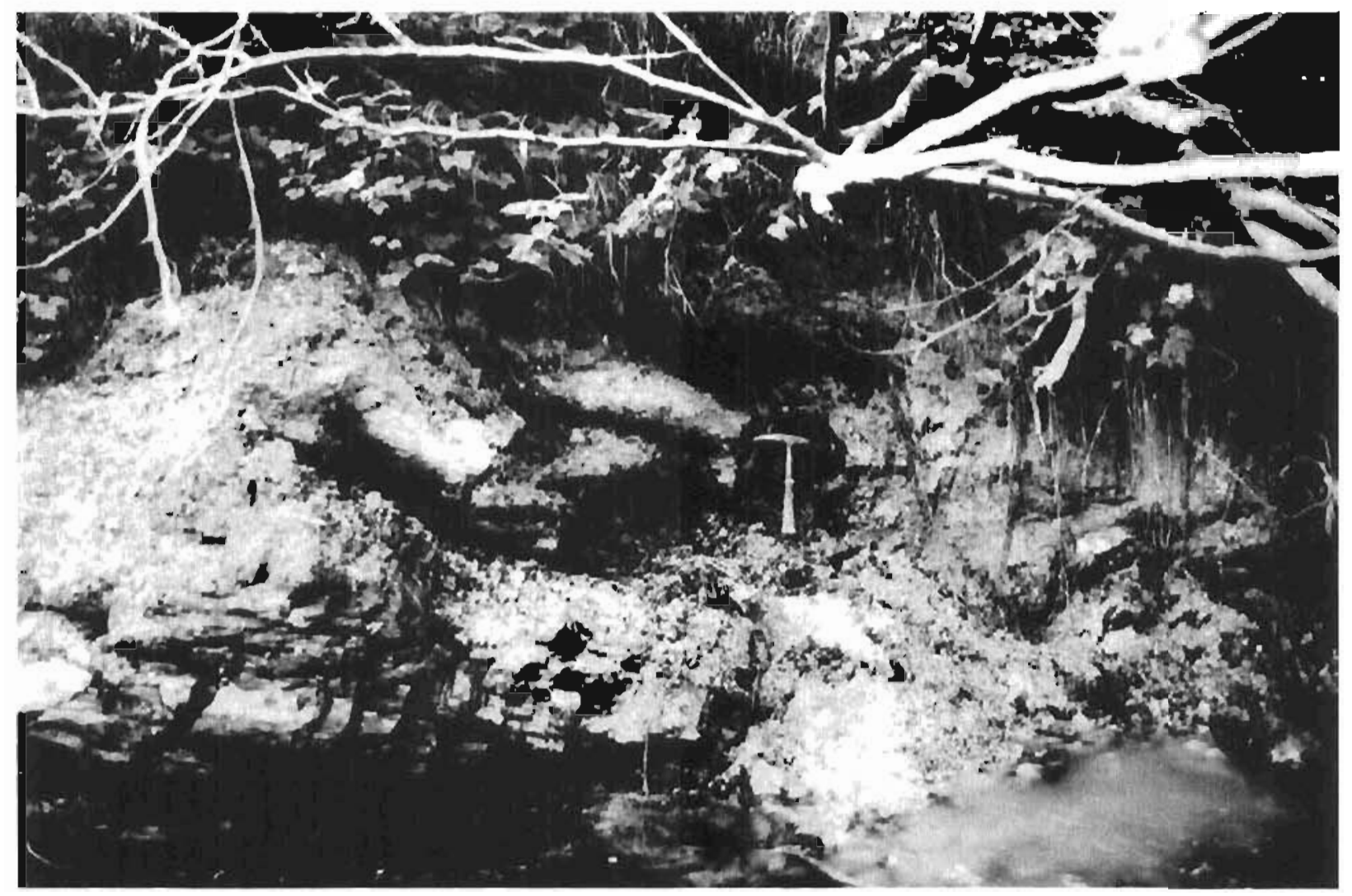

Figure 51. Weathering gleys from burn macerial in a coal-bearing section of the Tyonek Formation, Chuitna River, beluga coalfleld. Photograph by J.E. Sperber, 1981.

A broad spectrum of overburden characterization aralyses was pertormed on Susitna lowland saniples during this stury (table 22; app. E, table L-1 through: E-9). Nithough gufdeline criteria to evaluate the character and quality of overburden have been developed in several other states, including. Wyoming and Montana (app. E, Lables E-J0 and E-11), none have been establicilied for Aláka.

Texture

On a plot of particle sizes and resultant textules for Susitna lowland overburden samples (Eig. 52), several samples feil within the 'poor' cexture zones. Cenerally, regraded spoll material that is derived from overburden with high sand ( $>70$ percent), high clay ( $>40$ percent) content, or bouldery surface (as glacial till) may creatc revegetacion problems. High-cilay zones produce effective aquicludes; high sand zones exhibit unfavorable moistureretention qualties; and large boulders create a medium that may concain 11tite fine-grained matrix materlal and organic matter (Dollhopf and others, 1978). On the basis of unconfined compressive-strength tests of codliteld samples from the Capps dirtrict, Chleborad and others (1980; 1982) concluded that the materials ranged from soft soil to soft rock (fig. 53).

During dragline spoiling, overburden with a higl clay content can be mixed with overburden with a high or moderate sand concenc to improve soil 
Table 22. Summary, overburdencharacterization unalyses of Susitna Lowland samples.

\begin{tabular}{|c|c|c|c|c|c|}
\hline \multicolumn{2}{|l|}{ Parametel: } & Samples & Locales & Range & Meán \\
\hline \multicolumn{2}{|l|}{ paste pH } & 88 & 8 & $4.1 \cdot 7.8$ & 6,4 \\
\hline \multicolumn{2}{|l|}{ Electrical conductivity } & 88 & 8 & $0.1 .0 .9 \mathrm{mmhos} / \mathrm{cm} @ 25^{\circ} \mathrm{C}$ & $0.3 \mathrm{mmhos} / \mathrm{cm}$ @ $25^{\circ} \mathrm{C}$ \\
\hline \multicolumn{2}{|l|}{ Saturation } & 88 & 8 & $24.2 .94 .1 \%$ & $52.8 \%$ \\
\hline Saturation & $\mathrm{Ca}$ & & & $0.1 \cdot 6.3 \mathrm{meq}^{\prime} /$ & $1.9 \mathrm{mec} / \mathrm{l}$ \\
\hline exlracl & $\mathrm{Mg}$ & 28 & 3 & $<0.1 .4 .4 \mathrm{meq} / 1$ & $1.3 \mathrm{meq} / 1$ \\
\hline cations & $\mathrm{Na}$ & & & $0.4-0.8 \mathrm{meq} / 1$ & $0.6 \mathrm{meq} / \mathrm{l}$ \\
\hline \multicolumn{2}{|c|}{ Sodium adsorplion ratio (SAR) } & 28 & 3 & $0.3 \cdot 2.2$ & 0.6 \\
\hline \multicolumn{2}{|c|}{$\begin{array}{l}\text { Exchangcable sodium percentage } \\
\text { (ESP) }\end{array}$} & 51 & 3 & $0.7 .506 .4 \%$ & $16.5 \%$ \\
\hline \multicolumn{2}{|c|}{ Particle size } & 64 & 3 & Variable & $\ldots$ \\
\hline \multicolumn{2}{|l|}{ Texture } & 54 & 3 & Variable & $\cdots$ \\
\hline \multicolumn{2}{|l|}{ Organic matter } & 86 & 4 & $0.82 \cdot 11.88 \%$ & $4.7 \%$ \\
\hline \multicolumn{2}{|l|}{ Lime } & 36 & 4 & $7.7 \cdot 10.1 \%$ & $9.8 \%$ \\
\hline \multicolumn{2}{|l|}{ Boron (total) } & 20 & 2 & $1.3 \cdot 100.0 \mathrm{ppm}$ & $33.8 \mathrm{ppm}$ \\
\hline \multicolumn{2}{|l|}{ Selenium (Lotal) } & 20 & 2 & $<0.01-0.05 \mathrm{ppm}$ & $\ldots$ \\
\hline \multirow[t]{3}{*}{ Extractable nutrients } & $\mathrm{NO}_{3} \cdot \mathrm{N}$ & & & $2.1 \cdot 13.8 \mathrm{ppm}$ & $4,0 \mathrm{ppm}$ \\
\hline & $\mathrm{p}^{\mathrm{o}}$ & 43 & 6 & $6.85-38.54 \mathrm{ppm}$ & $15.44 \mathrm{ppm}$ \\
\hline & $1 K$ & & & 47.6-280.1 ppm & $136.4 \mathrm{ppm}$ \\
\hline \multirow{4}{*}{$\begin{array}{l}\text { Ammonium } \\
\text { acelate } \\
\text { extractablc } \\
\text { cations }\end{array}$} & $\mathrm{Ca}$ & & & $2.5-45.4 \mathrm{meq} / 100 \mathrm{~g}$ & $10.3 \mathrm{meq} / 100 \mathrm{~g}$ \\
\hline & $\mathrm{Mg}$ & 54 & 3 & $0.3-9.0 \mathrm{meq} / 100 \mathrm{~g}$ & $3.3 \mathrm{mcq} / 100 \mathrm{~g}$ \\
\hline & $\mathrm{Na}$ & & & $0.6 \cdot 39.5 \mathrm{meq} / 100 \mathrm{~g}$ & $1.4 \mathrm{meq} / 100 \mathrm{~g}$ \\
\hline & $\mathrm{K}$ & & & $<0,1 \cdot 0.7 \mathrm{meq} / 100 \mathrm{~g}$ & $0.2 \mathrm{meq} / 100 \mathrm{~g}$ \\
\hline \multicolumn{2}{|c|}{ Cation exchange capacity } & 54 & 3 & $1.3-88.4 \mathrm{meg} / 100 \mathrm{~g}$ & $20.0 \mathrm{meg} / 100 \mathrm{~g}$ \\
\hline \multicolumn{2}{|c|}{ Base saturation } & 54 & 3 & $16.7 \cdot 100.0 \%$ & $83.4 \%$ \\
\hline \multirow[t]{3}{*}{ Sulfur } & $\mathrm{SO}_{4} \cdot \mathrm{S}$ & & & $<0.1 \%$ & $\ldots$ \\
\hline & Pyritic & 28 & 3 & $<0.01 \cdot 0.09 \%$ & $\ldots$ \\
\hline & Total & & & $0.00-0.48 \%$ & $0.07 \%$ \\
\hline & & & $0.0-30.0 \mathrm{meq} \mathrm{H}^{+} / 100 \mathrm{~g}$ & $4.1 \mathrm{meq} \mathrm{H}^{+} / 100 \mathrm{~g}$ \\
\hline \multicolumn{2}{|l|}{ Neutralization potential } & 88 & 8 & $\begin{array}{l}3.85 \cdot 213.84 \text { tons } \mathrm{CaCO}_{3} \mathrm{eg} . / \\
1,000 \text { tons }\end{array}$ & $\begin{array}{l}24,2 \text { tons } \mathrm{CaCO}_{3} \mathrm{eg} / \\
1,000 \text { tons }\end{array}$ \\
\hline \multicolumn{2}{|l|}{ Polential acidity ${ }^{\prime 4}$} & & & $\begin{array}{l}-6.55-212.89 \text { lons } \mathrm{CaCO}_{3} \mathrm{eg} . / \\
1,000 \text { tons }\end{array}$ & $\begin{array}{l}+22.3 \text { tons } \mathrm{CaCO}_{3} \mathrm{eg.} / \\
1,000 \text { Lons }\end{array}$ \\
\hline
\end{tabular}

"Positive values Indicate excess $\mathrm{CaCO}_{3}$ or basic overburden malcríal.

texture and drainage characteristjcs in some areas of the Sustena lowland. Dollhopf and others (1978) mixed an overburden sample of 9 percent clay with an overburden sample of 57 percent clay in proportions of $3: 1,1: 1$, and $1: 3$, containing 25,40 , and 49 percent clay, respectively, which represented a near-linear relationship. Overburden in the Susitna lowland exhibits abrupt vertical and lateral. changes in clay content, which reveals rapid alteration during local depositional processes. Texcure can be considerably improved by mixing to ciflute the clay content and to produce a more destrable plant-root medium through which water will percolate more easily.

\section{Acidity}

Overburden at liairview Mountain exhibited pH values as low as 4.1 (figs. 54 and 55) and, in at least two samples, deficiencies of ameliorating capacity (over 5 tons $\mathrm{CaCO}_{3}$ equivalent pex $\mathrm{l}, 000$ tons of material; $f 1 g$. 55). However, the highest pyritic-sulfur content of the roof and floor beds of coal seams $c$ through $F$ was $<0.06$ percent, and highest rotal sulfur content $<0.48$ percent (fig. 55). The acidity of the ovexburden sirata probably resulted from biochemlcal breakdown of organtc matter, which ranged from 1.27 to 11.89 percent 


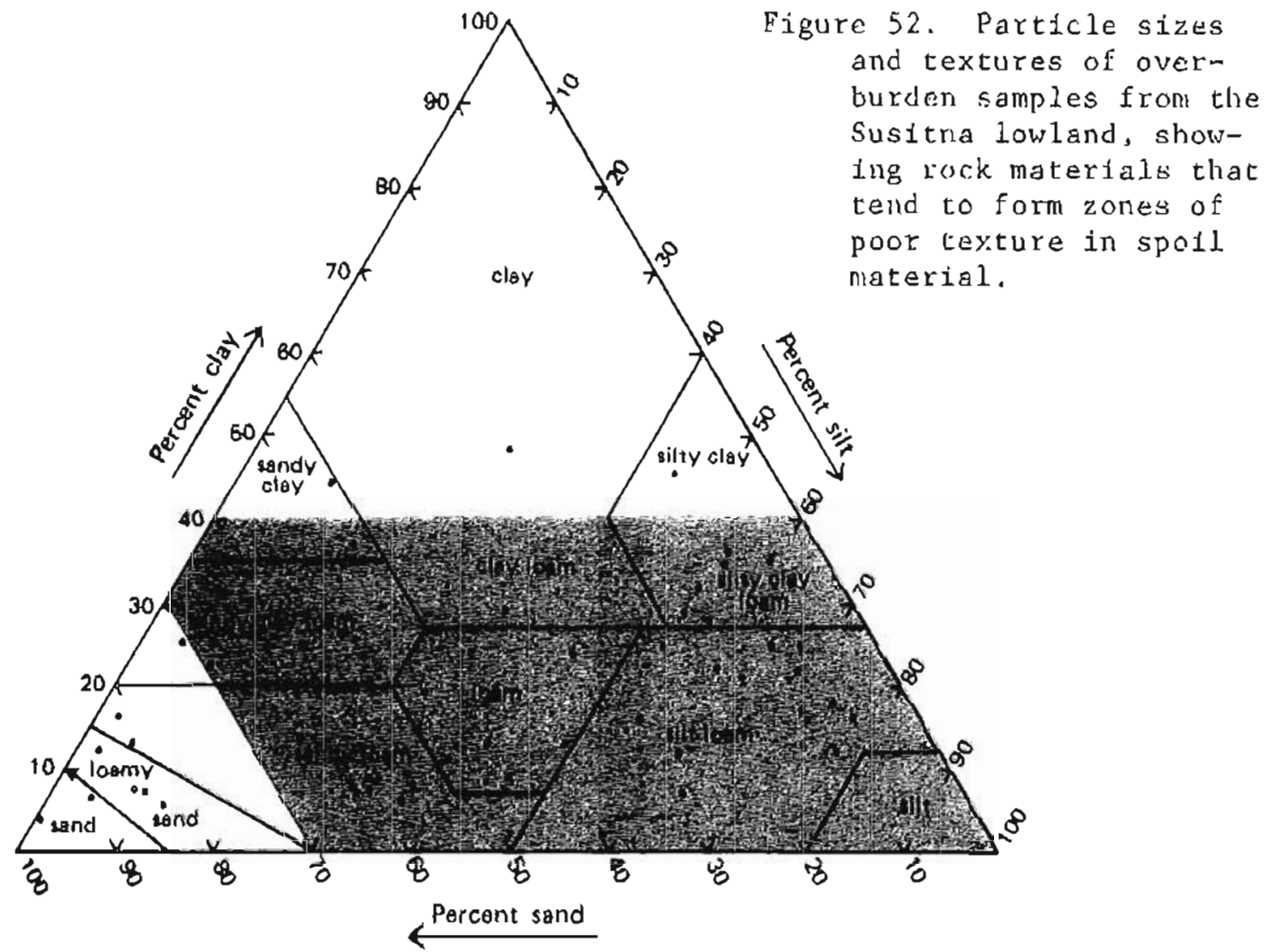

Poor texture zones ( $>40 \%$ clay and $>70 \%$ sand)

In the analyzed samples. Groenewold and others (1981) found that this process ofter led to higher acidity than did oxtdation of disseminated pyrite.

Acldity should not be a significant problem in most areas of southcentral Alaska. However, overburden strata with as little as 0.3 percent sulfur in the form of fine-grained disseminated pyrite (particularly as framboids) can cause acidity and revegetation problems on reclaimed spoil. Pyrite framboids occur in certain Susitna lowland coals (Merritt, 1982); in weathered (oxidized) overburder sequences, soluble sulfate salts may be abundant. The Inherent alkalinity level $\left(\mathrm{CaCO}_{3}\right.$ content) ameliorates existing acidity.

\section{Saline-sodic spoil}

Although materials characterized by excess soluble salts and a high level of adsorbed sodium are common in the arid to semiarld regions of the western United States, analytical results of this study supported the concluston of Mitchell and others (1981) that saline and sodic spoil should not be a major problem in Alaska coal basins. They found no zones of salt accumulation and no sodxum-adsorption levels that would be detrimental to plant growth in the materials they examined from the Usibelli Mine at Healy, the Capps district of the Beluga field, an abandoned strip mine in Matanuska Valley near Sutton, and an abandoned site at Meade River. Electrical conductivities in Susitna lowland 


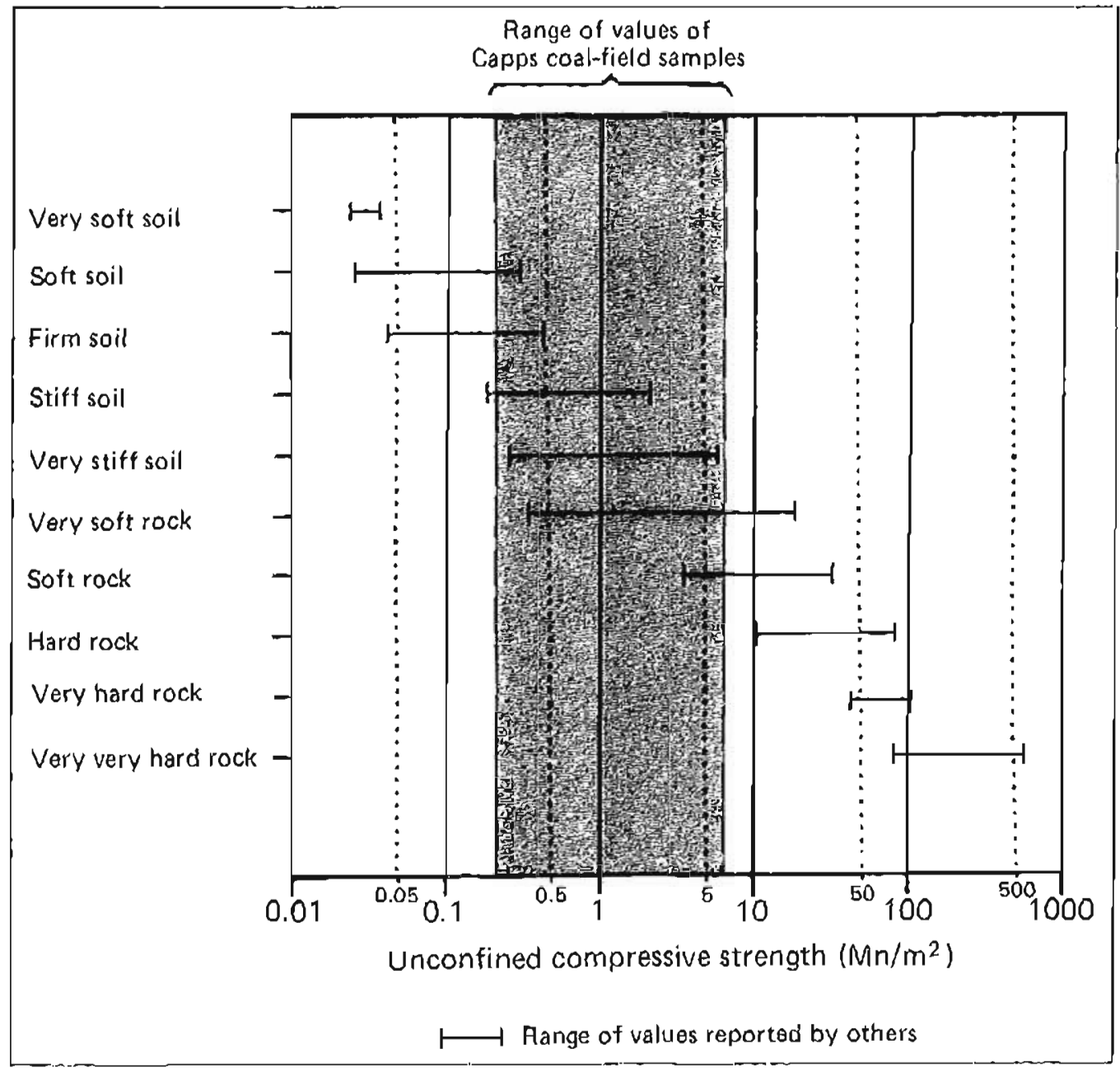

Figure 53. Range of unconfined compressive strength for Capps area coal samples. Modified from Chleborad and others (1980, 1982).

samples analyzed in this study ranged from 0.1 to $0.9 \mathrm{mmhos} / \mathrm{cm}$ at $25^{\circ} \mathrm{C}$, and the mean sodium-adsorption ratio was $<1.0$. Although a few samples exhibited enomalously high exchangeable-sodium percentages, the mean value (tables 22 and 23) was 16.5 percent.

\section{Cation-exchange capacity}

The 54 overburden samples anglyzed from three sites in the Susitna lowland ranged from 1.3 to $88.4 \mathrm{mEq} / 100 \mathrm{~g}$, with a mean of $20.0 \mathrm{mEq} / 100 \mathrm{~g}$. Shale and mudstone gencrally had relatively high cation-exchange capactties (CEC), which indicates the presence of montmorilionite and avallability of adequate. plant nutrients for use as a subsoil medium. The CEC in sandstones rarely exceeded $5 \mathrm{mEq} / 100 \mathrm{~g}$ unless the sandstone was argillaceous.

\section{Trace elements}

Few baseline data exist to establish acceptable trace-element levels in overburden, particulariy in Alaska. Hinckley and others (1982) concluded that 


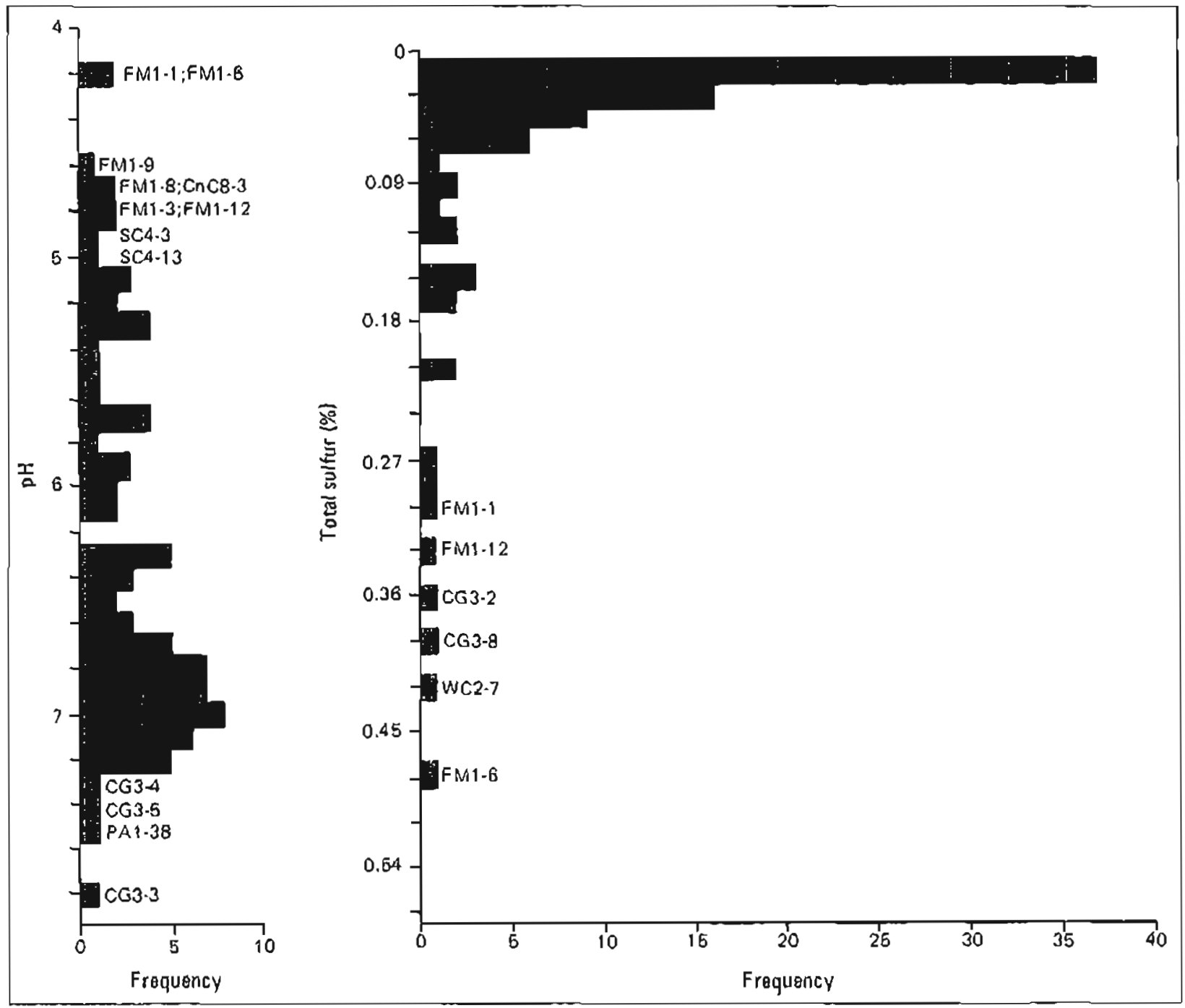

Figure 54. Histograms of $\mathrm{pH}$ and total-sulfur content for overburden samples. from the Susitna lowland. Frequency expresses number of samples exhibiting a particular value. Samples having extreme values are designated by sample code (see apps. C and E).

considerable variation occurs in rock chemistry and depositional environments over short distances in the Beluga coal area and fine-grained rocks (claystone) typically contain at least twice the amount of trace elements that coursegrained rocks (sandstones) do (table 24). Overburden samples from several localities in the Susttra lowland (Beluga River, Capps Glacier, Falrview Mountain, Peters Hills area, Saturday Creek, and Wolverine Creek) revealed significantly higher levels of trace elements such as lead, zinc, nickel, cobalt, and cadmium than those recommended for prime topsol.1 or subsoil media (f1g. 56).

The maximum selenium content of 20 samples from two Susitna lowlard sites (table 22) was well below the toxicity threshold level of $2 \mathrm{ppm}$, but total-boron content indicated excess boron concentrations (>5 ppm) in mine 


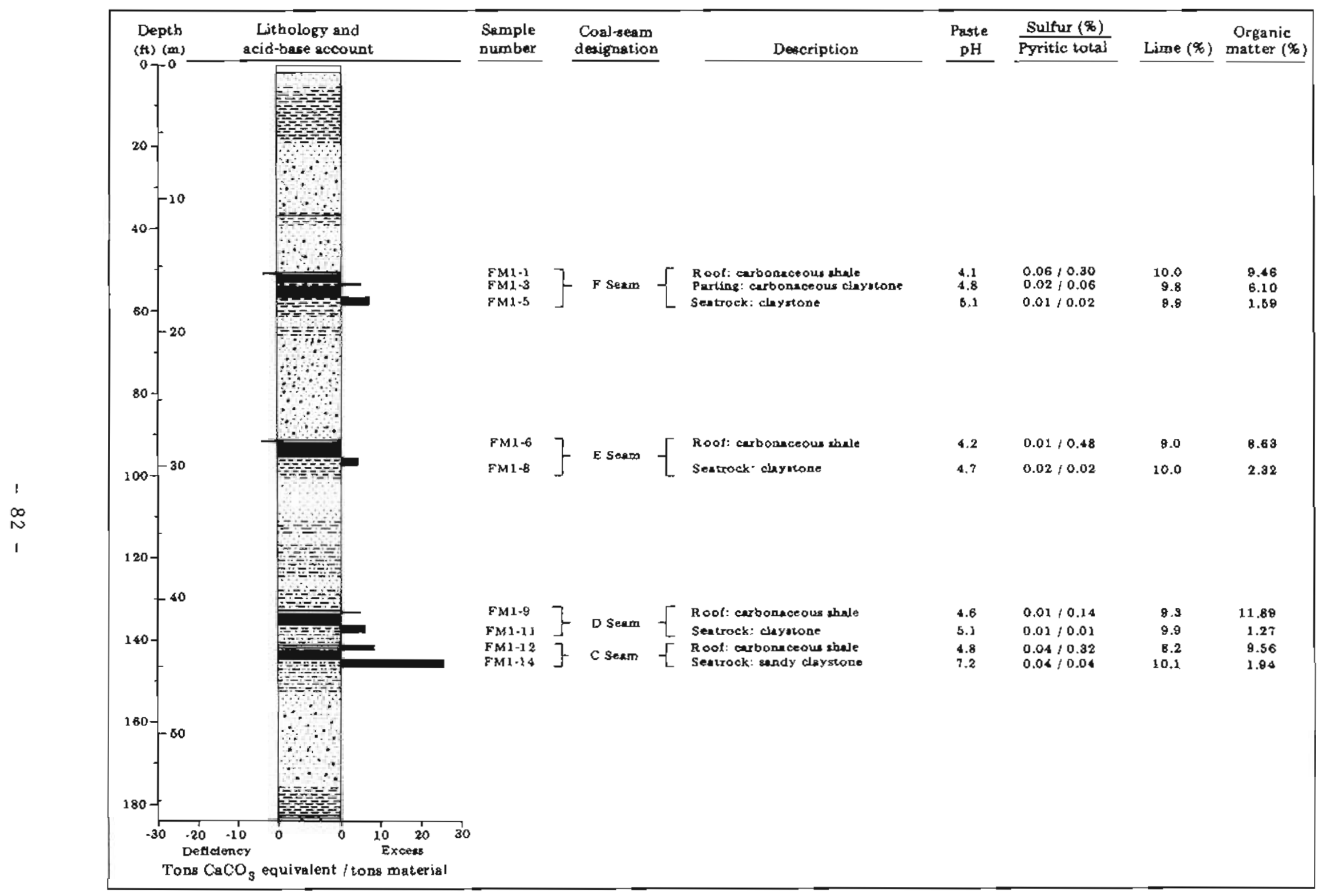

Figure 55. Overburden-interburden characteristics for a coal-bearing section from Fatrview Mountain, Tyonek Formation, northwest Yentna field. 
Table 23. Geochemical paramelers measured in delewnining the levels of soluble salts and sodium in soils and overburden.

Parameter

Conductivity (EC)

Saturation percentage (SP)

Saturation extract cations

Sodium $\left(\mathrm{Na}^{+}\right)$

Calcium $\left(\mathrm{Cat}^{++}\right)$

Magnesiun $\left(\mathrm{Mg}^{4++}\right)$

Sodium adsorption ratio (SAR)

Exchangeable sodiun percontage (ESP)
Characteristics

Directly related to soil salinity. Conductivities over $16 \mathrm{mmhos} / \mathrm{cm}$ at $25^{\circ} \mathrm{C}$ gellerally rated as unguitaible, and from 8 to $16 \mathrm{mmhos} / \mathrm{cm}$ at $25^{\circ} \mathrm{C}$ os poor (table D10).

Moisture content of a given inalerial at its point of saturation. High saturation ( $>80 \%$ ) can often be correlated with high clay strata.

Tends to disperso clay materials, hence reducing aeration and soil hydraulic conductivity. Adverse structural modification to a soil is usually due to excess sodium concentralions.

Directly affects the drainage and leaching of soils; results in a sodic condition.

Low inagnesiun levels can reduce the concentrations of phosphorous. High levels of calcium ions may alleviate toxic reactions of plants with high concentrations of magnesium (U.S. Department of Agriculture, 1954).

Determined from the modified Gapon equation: $S A R=N a / 7(\overline{C a}+\mathrm{Mg}) / 2$.

A material with an SAR value above 15 is judged unsuitable as a plant rool-zone medium (Sandoval and Gould, 1978).

Defines the extent in which the adsorption complex of a soil is occupied by sodium. High-clay materials usually have attendant high exchangeable sodium contents and an SAR value above 10 (Sandoval and Gould, 1978). Soils with high ESPs (>15\%) and high SARs tend to have serious physical problems, resulting in low hydraulic conduclivity, poor aeration, and reduced productivity.

spoil that could be a problem for revegetation. Molybdenum concentrations in all Susitna lowland overhurden samples alralyzed were < 15 ppin; at this level, molybdenum may be concentrated in plant tissues and cause molybdenosis in grazing ruminants. I,ead content in the overburden samples ranged to about $50 \mathrm{ppm}$; generally, materials with lead levels higher than 10 ppm should be selectively handled.

Dollhopf and others (19\%) cited an example of mixing inhabitory strata (lead concentration 1.5 ppni) with overburden strata (lead concentration 1 ppm), which resulted in a spoil-pile concentration of between 3 and 5 ppm lead. If left near the reclajimed surface, concentracions at this level would not harm plant growth. Scattering spoil macerial through the dragline swing cycle, rather than dumping it at the end of the cycle, results in a more chenically and physically homogeneous and environmentally acceptable spoit medium.

\section{Macronutrients and micronutrients}

Extractable-nutrient levels were analyzed in 43 overburden samples from six sites in the Sutitna lowland (table 22). Results indicated that the samples were deficlent in the major plant nutrients nitrogen and phosphorus (and sometimes potassiun); these nutionts would have to be adjed if the overburden 
Table 24. Geometric means (ppm) for certain trace element contents in overburden samples from the Susitna Lowland (present study), Capps coal field, and suites from other areas in the conterminous United States (Hinchley and others, 1982).

\begin{tabular}{|c|c|c|c|c|c|c|c|c|c|}
\hline \multirow[b]{2}{*}{ Trace element } & \multirow{2}{*}{$\begin{array}{l}\text { Rock } \\
\text { type }\end{array}$} & \multirow{2}{*}{$\begin{array}{c}\text { Susitna Lowland } \\
\text { overburden }\end{array}$} & \multicolumn{2}{|c|}{$\begin{array}{l}\text { Capps field } \\
\text { overburden, } \\
\text { Beluga area, } \\
\end{array}$} & \multirow{2}{*}{$\begin{array}{l}\text { Ft. Union } \\
\text { Fm } \\
\text { overburden }\end{array}$} & \multirow{2}{*}{$\begin{array}{l}\text { Kimbeto, } \\
\text { N.M. } \\
\text { overburden }\end{array}$} & \multirow{2}{*}{$\begin{array}{c}\text { Cretaceous } \\
\text { overburden } \\
\text { suite } \\
\end{array}$} & \multicolumn{2}{|c|}{ San Juan Basin } \\
\hline & & & 1979 & $\underline{1980}$ & & & & Topsoils & Minesoils \\
\hline \multirow[t]{2}{*}{ Boron } & 1 & 22 & 17 & $\cdots$ & 42 & 13 & 14 & \multirow[t]{2}{*}{7} & \multirow[t]{2}{*}{13} \\
\hline & 2 & 37 & 26 & - & 59 & 19 & 28 & & \\
\hline \multirow[t]{2}{*}{ Chromium } & 1 & $\cdots$ & 35 & 39 & 46 & 19 & 16 & \multirow{2}{*}{22} & \multirow{2}{*}{14} \\
\hline & 2 & $\cdots$ & 61 & 70 & 72 & 30 & 43 & & \\
\hline \multirow[t]{2}{*}{ Cobalt } & 1 & 12 & 7 & 6 & 11 & 8 & 4 & \multirow{2}{*}{6} & \multirow{2}{*}{9} \\
\hline & 2 & 16 & 9 & 8 & 9 & 12 & 9 & & \\
\hline \multirow[t]{2}{*}{ Copper } & 1 & 28 & 11 & 23 & 14 & 14 & 7 & \multirow{2}{*}{10} & \multirow{2}{*}{18} \\
\hline & 2 & 51 & 40 & 43 & 38 & 39 & 30 & & \\
\hline \multirow[t]{2}{*}{ Lead } & ] & 15 & 11 & 22 & 12 & 10 & 6 & \multirow{2}{*}{11} & \multirow{2}{*}{11} \\
\hline & 2 & 26 & 20 & 37 & 11 & 16 & 13 & & \\
\hline \multirow[t]{2}{*}{ Manganese } & 1 & 761 & 167 & 412 & 233 & 183 & 75 & \multirow[t]{2}{*}{260} & \multirow[t]{2}{*}{340} \\
\hline & 2 & 804 & 302 & 303 & 300 & 105 & 209 & & \\
\hline \multirow[t]{2}{*}{ Molybdenum } & 1 & $<10$ & 2 & -- & 2 & 2 & 2 & \multirow[t]{2}{*}{2} & \multirow[t]{2}{*}{3} \\
\hline & 2 & $<10$ & 2 & $-\cdot$ & 6 & 3 & 2 & & \\
\hline \multirow[t]{2}{*}{ Nickel } & 1 & 26 & 23 & 24 & 26 & 12 & 10 & \multirow[t]{2}{*}{9} & \multirow{2}{*}{12} \\
\hline & 2 & 52 & 36 & 38 & 30 & 23 & 27 & & \\
\hline Vanadium & 1 & $\cdots$ & 60 & 71 & 75 & 60 & 37 & 45 & 56 \\
\hline & 2 & $\cdots$ & \pm 19 & 117 & 86 & 90 & 91 & & \\
\hline Yturium & I & $\cdots$ & 17 & 15 & 30 & 26 & 19 & 27 & 32 \\
\hline & 2 & $\cdots$ & 28 & 21 & 19 & 33 & 30 & & \\
\hline Zinc & 1 & 60 & 61 & 102 & 62 & 61 & 35 & 48 & 56 \\
\hline & 2 & 100 & 108 & 143 & 59 & 80 & 105 & & \\
\hline
\end{tabular}

A-Coarse graned (sandstones)

2-Fine pramed (claystones). 


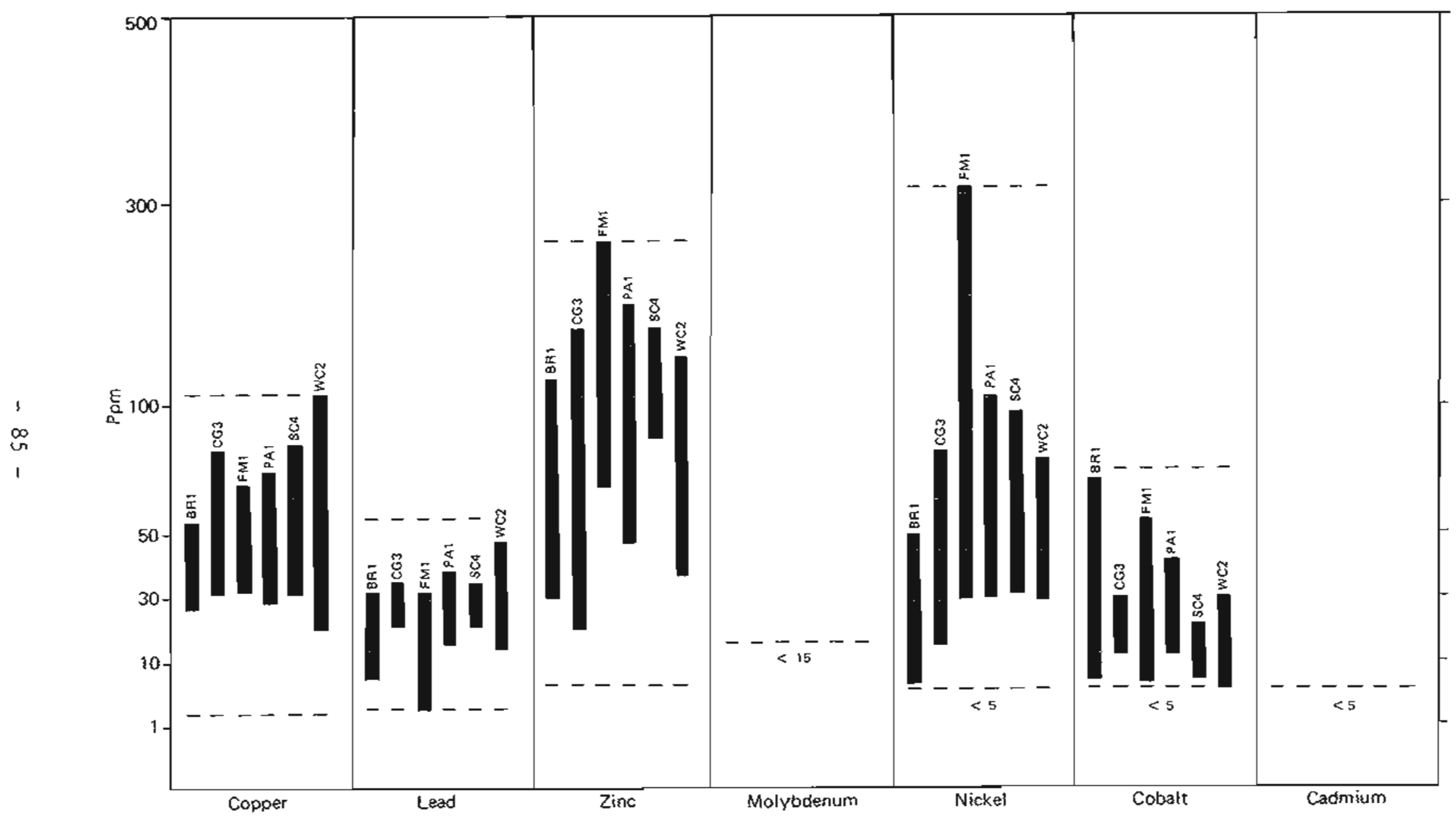

Figure 56. Range of certain trace elements in overburden materials at six sites in the Susitna lowland. $\mathrm{BR}=$ Beluga River, $\mathrm{CG}=$ Capps Glacier area, $\mathrm{FM}=$ Fairview Mountain, PA = Peters Hills area, $\mathrm{SC}=$ Saturday Creek, and $\mathrm{WC}=$ Wolverine Creek. 
were to be used as a subsoil medium. The overburden material was not deficient in the common inicronutrients (iron, manganese, zinc, boron, molybdenum, and copper) olthough zinc, boron, molybdenum, and manganese levels in some samples may point to a potential problem with metal phytotoxicity.

In summary, coal overburden evaluations of the Susicna lowland samples yielded six ma1n results: (1) poor texture zones can occur in regraded spoil materials that will cause dralnage and revegetation problems; (2) any acidity problems will be minor and localized; (3) the potential. for development of saline-sodic soil conditions is low; (4) toxic levels can result locally fron certain trace elements such as boron, molybdenum, and lead in spoil materials; (5) positive growth response can be expected when macrolutrients nitrogen and phosphorus are adoed; and (6) certain micronutrients (zinc, boron, molybdenum, and manganese) are not deficient but can cause problems of local metal

phytotoxicity.

\section{CONCLUSIONS}

The Tertiary kenai Group of the Susitna lowland in southcentral Alaska contains substantial reserves of subbituminous coal suitable for surface mining. Most coal resources occupy a crescent-shaped belt along the wescern and southern margin of the Susitna lowland. Although estimites of resources and reserves vary significantly, total mineable reserves amount to several billion tons. These coals are especlally attractive because of their extremely low sulfur content and their proximity to prospective Pacific Rim markets.

The coali are generally comparable in quality with those of the powder River basin in the western U.S. Calorific and mean-maximum-reflectance values indicate that most Susitna lovland coals are of subbituminous rank.

Although the coals are laterally discontinuous and sometimes high in ash content, the numerous seams--particularly within the Tyonek Formation--and the geochemical and physical character of the enclosing strata make several coalfields economically attractive, Subsurface information is, unfortunately, scant, and the true extent of these deposits is unknown.

Petrologic studies indicate that most Susitna lowland couls originated in forest-moor environments within the telmatic zone. Northern Yentna field coals (upper Tyonek and Stcrling Formations) probably originated in a drier paleoenvironment (perhaps in the terrestrial zone) from tree-vegetation peats.

Overburden ts low in sulfur (<0.5 percent), which occurs mainly in the organic form. Acidity and high levels of soluble salts and adsorbed sodium do not appear to constitute major problems. Isolated acid conditions, however, can develop, and levels of certain trace elements in overburden materials, lerraded spoils, and surface and ground waters should be montcored. Textures In the regraded-spoil profile can pose drainage and revegetation problems. 
SELECTED BIBLIOGRAPHY

Aamodt, P.L., Jacobsen, S.I., and HA11, D.E., 1979, Urantum hydrogeochemica] and stream sediment reconnalssance of the McGrath and Talkeetna Mountalns Quadrangles, Alaska, including concentrations of furty-three elements: U.S. Department of Energy Report CJBX-123(79), 214 p.

Adkison, W.L., Kelley, J.S., and Newman, K.R., 1975, Lithology and palynology of Tertlary rocks exposed near Capps Glacier and along Chuitna River, Tyonek Quadrangle, southern Alaska: U.S. Geological Survey Open-file Report 75-21, $58 \mathrm{p}$.

Alaska Department of Comerce and Economic Development, 1979, Alaska regional energy resources planning project, phase 2: Alaska Department of Commerce and Economic Development, Coal, hydroelectric, and energy alternatives, v. $1,452 \mathrm{p}$.

Alaska Division of Geological and Geophysical Surveys, 1973a, Aeromagnetic map, Anchorage Quadrangle, Alaska: Fairbanks, Alaska Division of Geologlcal and Geophysical Surveys Open-file Report 21 , scale $1: 250,000$.

1973b, Aeromagnetic map, Talkeetna Quadrangle, Alaska: Fairbanks, Alaska Division of Geological and Geophysical Surveys Open-file Report 19, scale $1: 250,000$.

1973c, Aeromagnetic map, Talkeetna Mountains Quadrangle, Alaska: Fairbanks, Alaska Division of Geological and Geophysical Surveys Open-file Report 20, scale 1:250,000.

Alaska Geological Soclety, 1969, West to east stratigraphic correlation section, West Foreland to Swan Lake, upper Cook Inlet basin, A.laska: Anchorage, scale $1 \mathrm{in}$. $=500 \mathrm{ft}$.

Alaska Power Administration, 1970, Development of new lands in Matanuska-Sus1tna Borough: U.S. Department of Inter1or, Alaska Power Administration, $90 \mathrm{p}$.

American Soclety of Agronomy, 1965, Methods of soll analysis; part 2, Chemlcal and microblological properties: American Society of Agronomy Monograph 9, p. $771-1572$.

American Society for Testing and Materials, 1981, Standard speclffcations for classification of coals by rank (ASTM designation D-388-77): 1981 Annual book of ASTM standards, part 26, p. 212-216.

Anderson, Donald, 1978, Feaslbility study of mining Alaska coal and transportation by slurry to the West Coast: U.S. Bureau of Mines Open-file Report 17(1)-78, $30 \mathrm{p}$. 
Anderson, G.S., 1969, Geology and geochemistry of the Wells Mountain area, Talkeetna Mountains Quadrangle, Alaska [abs.], in Alaska Division of Mines and Geology Report for the year 1969: Eairbanks, Alaska Division of Geologlcal and Geophysical Surveys, p. 7.

Anderson, R.E., 1969a, Geology and geochemistry, Diana lakes area, western Talkeetna Mountains, Alaska: Falrbanks, Alaska Division of Geological and Geophysical Surveys Geologic Report 34, 27 p., scale 1:48,000.

1969b, Preliminary geochemistry and geology, Little Falls Creek area, Talkeetna Mountalns Quadrangle, Alaska: Falrbanks, Alaska Division of Geological and Geophysical Surveys Geochemical Report 19, 16 p., scale $1: 45,000$.

Andreasen, G.E., 2ietz, Istdore, and Grantz, Arthur, 1958, An aeromagnet1c reconnaissance of Cook Inlet area, Alaska [abs.]: Amerlcan Association of Petroleum Geologists Bulletin, v. 42, no. 1, p. 219-220.

Atwood, W.W., 1909, Mineral resources of southwestern Alaska: U.S. Geological Survey Bulletin 379, p. 108-152.

Averitt, Paul, 1961, Coal reserves of the United States - a progress report, January 1, 1960: U.S. Geological Survey Bulletin 1136, 116 p.

Averitt, Paul, and Lopez, Loreda, 1972, Bibllography and index of U.S. Geological Survey Publications relating to coal, 1882-1970: U.S. Geological Survey Bulletin 1377, 99 p.

Ayres, M.G., 1964, Regional geology of the Cook Inlet area, Alaska, in Guldebook, Alaska Geological Society, p. 28-36.

Balley, A., 1981, Chemical and mineralogical differences between kittanning coals from marine-influenced versus fluvial sequences: Journal of Sedimentary Petrology, v. 51, no. 2, p. 383-395.

Barnes, D.F., 1976, Bouguer gravity map of Alaska: U.S, Geological Survey Open-file Report 76-70, scale 1:2,500,000.

Barnes, F.F., 1951, Coal investigations in southcentral Alasks, 1944-46: U.S. Geological Survey Bulletin 963-E, p. 137-213.

1959, Geology and coal resources of the Little Susitna district, Matanuska coal fleld, Alaska: U.S. Geological Survey Bulletin 1058-D, p. $121-138$.

1961, Coal fields of the United States, sheet 2 - Alaskai U.S. Geological Survey Map, scale $1: 5,000,000$.

1962a, Geolog1c map of lower Matanuska Valley, Alaska: U.S. Geological Survey Miscellaneous Geologic Inventory Map I-359, scale $1: 63,360$. 
1962b. Variation in rank of Tertiary coals in the Cook Inlet basin, Alaska, in Geolog1cal Research, 1962: U.S. Geological Survey Professional Paper $45 \overline{0-C}$, p. C14-Cl6.

1964, Coal, In Mineral and water resources of Alaska: U.S. 88th Congress, Second Session, Senate Committee Interior and Insular Affairs, Commercial Print 31-068, p. 82-88.

1966, Geology and coal resources of the Beluga-Yentna region, Alaska: U.S. Geological Survey Bulletin 1202-C, 54 p.

1967, Coal resources of Alaska: U.S. Geologica1 Survey Bulletin $1242-B, p . B 1-B 36$.

1968, Gravity map of Alaska: U.S. Geological Survey Professional Paper 600-A, p. A36-A39.

Barnes, F.F., and Cobb, E.H., 1959, Geology and coal resources of the Homer district, Kenal coal field, Alaska: U.S. Geologlcal Survey Bulletin 1058-F, p. 217-260.

Battelle Pacific Northwest Laboratorles, 1980, Beluga coal export market study: Report prepared for the State of Alaska, Office of the Governor, Division of Policy Development and Planning, $10 \mathrm{p}$.

Beaumont, E.A., 1979, Depositional environments of Fort Unton sediments (Tertiary, northwest Colorado) and their relation to coal: American Assoclation of Petroleum Geologists Bulletin, v. 63, p. 194-217.

Bechtel, Inc., 1980, Executive summary of preliminary feastbility study of coal export program, Bass-hunt-Wilson coal leases, Chuitna River field, Alaska: San Francisco, $19 \mathrm{p}$.

Beikman, Helen, 1980, Geologlc map of Alaska: U.S. Geological Survey, scale $1: 2,500,000,2$ sheets.

Bergquist, H.R., 196l, Early Cretaceous (middle Neocomian) microfossils in south-central Alaska: U.S. Geological Survey Erofessional Paper 424-D, p. D236-D237.

Berner, R.A., 1969, The synthesis of framboidal pyrite: Economic Geology, v. 64, no. 4, p. 383-384.

Berner, R.A., Baldwin, Timothy, and Holdren, G.R., Jr., 1979, Authigenic 1ron sulfides as paleosalinity indicators: Journal of Sedimentary Petrology, v. 49 , no. 4, p. $1345-1350$.

Blumer, J.W., 1981, Review of Mobil coal leases - Yentna region, Alaska, in Rao, P.D., and Wolff, E.N., eds., Focus on Alaska's Coal '80: Alaska Coal Conference, 2nd, Falrbanks, 1980, Proceedings, Falrbanks, University of Alaska Mineral Industry Research Laboratory Report 50, p. 122-126. 
Bohor, B.F., and Gluskoter, H.J., 1973, Boron in illite as an indicator of paleosalinity of Illinois couls: Journal of Sedimentary Petrology, v, 43, no. 4, p. $945-956$.

Boss, K.F., Lennon, R.B., and Wllson, B.W., 1978, Middle Ground shoal ofl field, Alaska, in Braunstein, Jules, ed., North America oil and gas Eields: American Association of Petroleum Geologists Memoir 24, p, 1-22.

Brooks, A.H., 1911, The Mount Mckinley region, with descriptions of the igneous rocks of the Bonnifleld and Kantishna district, by L.M. Prindle: U.S. Geological Survey Professional Paper 70, $234 \mathrm{p}$.

1914. Alaska coa1 and 1ts utilization: U.S. Geological Survey Bul1etin 442-J, p. 47-100.

Bruhn, R.L., 1979, Holocene displacements measured by trenching the Castle Mountain fault near Houston, Alaska, in Short Notes on Alaskan Geology - 1978: Falrbanks, Alaska Division of Geological and Geophysical Surveys Geologic Report 61, p. 1-4.

Bundtzen, T.K., Eakins, G.R., and Conwell, C.N., 1982, Review of Alaska's mineral resources: Alaska Department of Commerce and Economic Development Office of Mineral Development, p. 47-49.

Calderwood, K.W., and Packler, W.C., 1972, Proposed stratigraphic nomenclature, Kena1 Group, Cook Inlet basin, Alaska: Amertcan Association of Petroleum Geologists Bulletin, v, 56, no. 4, p. 739-754.

Capps, S.R., 1913, The Yentna district, Alaska: U.S. Geological Survey Bulletin 534, p. 23-36.

1919a, Mineral resources of the Upper Chulitna region: U.S. Geological Survey Bulietin 692, p. 207-232.

1919b. Mineral resources of the western Tajkeetna Mountains: U.S. Geological Survey Bulietin 692, p. 287-205.

1925, An early Tertiary placer deposit fin the Yentna district: U.S. Geological Survey Bulletin 773, p. 53-61.

1929, The Skwentna region, Alaska: U.S. Geological Survey Bulletin $797-B$, p. $67-98$.

1935, The southern Alaska Range: U.S. Geological Survey Bulletin $862,101 \mathrm{p}$.

1940, Geology of the Alaska Rallroad region: U.S. Geological Survey Bullettn 907, $201 \mathrm{p}$.

Carey, S.W., 1958, The tectonic approach to continental drift - a symposium: Hobart, University of Tasmania Geolngy Department, q. 177-355. 
Carter, R.D., and Adkison, W.L., 1972, Correlation of subsurface Tertiary rocks, Cook Inlet basin, Alaska: U.S. Geological Survey Open-file Report $72-64,8 \mathrm{p}$.

Caruccio, F.T., 1970, The quantification of reactive pyrite by grain size distribution: Symposium on Coal Mine Drainage Research, 3rd, Monroeville, Pennsylvania, 1970, Proceedings: Bituminous Coal Research Center, p. $123-131$.

Caruccio, F.T., Ferm, J.C., Horne, John, Geldel, Gwendelyn, and Baganz, Bruce, 1977, Paleoenvironment of coal and its relation to drainage quality: Environmental Protection Agency Interagency Energy-Environment Research and Development Program Report EPA-66/7-77-067, $108 \mathrm{p}$.

Chandra, D., 1962, Reflectance and microstructure of weathered coals: Fuel, v. 41, no. 2, p. 185-193.

Chap1n, Theodore, 1918, The Nelchina-Susitna region, Alaska: U,S, Geological Survey Bulletin 668, 67 p.

Chleborad, A.F., Yehle, L.A., Schmoll, H.R., and Gardner, C.A., 1980, Preliminary field geotechnlcal and geophysical logs from a drill hole in the Capps coal field, Cook Inlet region, Alaska: U.S. Geological Survey Open-file Report 80-393, 17 p.

Chleborad, A.F., Yehle, L.A., Schmol1, H.R., Gardner, C.A., and Dearborn, L.L., 1982, Preliminary geotechnical and geophysical logs from drill hole 2C-80 in the Capps coal field, Cook Inlet region, Alaska: U.S. Geological Survey Open-f1le Report $82-884,9$ p., 2 sheets.

Clardy, B.I., 1978, Stratigraphy of the Matanuska-Susitna area, northeastern Cook Inlet basin, Alaska: Denver, Colorado, Louisiana Land and Exploration Company, Western Division unpublished report, $15 \mathrm{p}$.

Clark, A.L., and Cobb, E.H., 1972, Metallic mineral resources map of the Talkeetna Quadrangle, Alaska: U.S. Geological Survey Miscel.laneous Field Studies Map MF-369, scale 1:250,000.

Cobb, E.H., 1972a, Metallic mineral resources map of the Talkeetna Mountalns Quadrangle, Alaska: U.S. Geological Survey Miscellaneoue Field Studies Map MF-370, scale $1: 250,000$.

$1972 \mathrm{~b}$, Metallic mineral resources map of the Tyonek Quadrangle, Alaska: U.S. Geological Survey Miscellaneous Field Studies Map MF-385, scale $1: 250,000$.

1980, Summary of references to mineral occurrences (other than mineral fuels and construction materials) in the Kenai and Tyonek Quadrangles, Alaska: U.S. Geological Survey Open-file Report 80-86, 37 p. 
Cobb, E.t., and Csejtey, Béla, Jr, , 1980, Summaries of data on and 11sts of references to metalic and selected nonmetalic mineral depostes in the Talkeetne Quadrangle, Alaska: U,S. Ccolog1cal, Survey Open-file Report $80-884,107 \mathrm{p}$.

Cohen, A.D., 1973, Petrology of some Holocene peat sediments from the Okefenokee swamp-marsh complex of southern Georgia: Geological Society of America Bulletin, v. 84, no. 12, p. 3867-3878.

Commltee on Alaskan Coal Mining and Reclamation (COACMAR), 1980, Surface coal mining in Alaska; an Investigation of the Surface Mining Control and Reclamation Act of 1977 in relation to Alaskan conditions: Fairbanks, University of Alaska School of Mineral Industry Special Publication 4, $328 \mathrm{p}$.

Congress of the United States, 1977, Surface Mining Control and Reclamation Act, Public Law 95-87: Federal Statutes, 91 STAT. 445-532.

Conwell, C.N., 1972a, Alaskan coals may prove a big plus in the future export picture: Mining Engineering, $v, 24$, no, 10, p. 82-84.

1972b, Alaskan coals: Soclety of Mining Engineers Transactions, v. 252 , no. 3, p. $279-282$.

1976, Reclaiming mined land in Alaska: Soclety of Mining Engineers Transactions, v. 260 , no. 3, p. $81-84$.

1977a, Energy resource map of Alaska: Fairbanks, Alaska Division of Geological and Geophysical Surveys, scale 1:2,500,000.

19776, Cook Inlet - Susitna coal flelds: Fairbanks, Alaska Division of Geological and Geophysical Surveys unpublished report, $32 \mathrm{p}$.

Conwell, C.N., Triplehorn, D.M., and Ferre11, V.M., 1982, Coals of the Anchorage Quadrangle, Alaska: Fairbanks, Alaska Division of Geological and Geophysical Surveys Special Report 17, 8 p., scale $1: 250,000,3$ sheets.

Couch, E.L., 1971, Calculation of paleosalinities fxom boron and clay mineral data: American Assoclation of Petroleum Geologists Eulletin, v. 55, no. 10, p. $1829-1837$.

Crelling, J.C., and Dutcher, R.R., 1980, Principles and applications of coal petrology: Bloomington, Indiana, Society of Economic Paleontologists and Mineralogists Short Course Notes $8,127 \mathrm{p}$.

Csejtey, Bdla, Jr, 1974, Reconnaissance geologic Investigations in the Talkeetna Mountalns, Alaska: U.S. Geological Survey Open-file Report $74-147,48 \mathrm{p}$. 
Csejtey, Bella, Jr., and Evarts, R.C., 1979, Serpentinite bodies in the Wlllow Creek district, southwestern Talkeetna Mountains, Alaska, in Johnson, K.M., and Williams, J.R., eds., The United States Geologlcal Survey in Alaska: Accomplishments during 1978: U.S. Geological Survey Circulat $804-B$, p. B92-894.

Csejtey, Béla, Jr., and Miller, R.J., 1978, Map and table descrihing metalliferous and selected nonmetalifferous mineral deposits, Talketna Mountains Quadrangle, Alaska: U.S. Geologlcal Survey Open-file Report $78-558 \mathrm{~B}, 20 \mathrm{p}$.

Csejtey, Bela, Jr., Nelson, W.H., Jones, D.L., S1lberling, N.J., Dean, R.M., Morr1s, M.S., Lamphere, M.A., Smith, J.G., and Silberman, M.L., 1978, Reconnalssance geologic map and geochronology, Talkeerna Mountains Quadrangle, northern part of Anchorage Quadrangle and southwest corner of Healy Quadrangle, Alaska: U.S. Geologlcal Survey Open-file Report 78-558-A, 62 p., scale $1: 250,000$.

Czurda, K., Winder, C.G., and Quigley, R.M., 1973, Sedimentology, mineral facies and petrofabric of the Meaford-Dundas Formation (Upper Ordovician) in southern Ontario: Canadian Journal of Earch Sciences, v. 10, no, 12, p. $1790-1804$.

Dal1, W.H., 1896, Report on coa1 and l1gnite of Alaska: U.S. Geological Survey 17 th Annual Report, pt. 1, sec. E, p. 763-906.

Dall, W.H., and Harris, G.D., 1892, Correlation papers, Neocene: U.S. Geological Survey Bulletin 84, p. 232-268.

Dames and Moore, 1974, Environmental baseline studies, proposed coal m1ning operations, Cook Inlet region, Alaska: Anchorage, report prepared for Placer Amex, Inc., and Starkey A. W1lson, $53 \mathrm{p}$.

Davies, J.N., and Berg, E., 1973, Crustal morphology and plate tectonics in south-central Alaska: Bulletin of the Seismological Soctety of America, v. 63, p. 673-677.

Dean, K.G., 1980, Surficial geology of the Susitma-Chulitna River area, Alaska: Falrbanks, Untversity of Alaska Geophysical Institute, Northern Remote Sensing Laboratory report prepared for Alaska bepartment of Natural Resources, 35 p., scale 1:125,000, lis sheets.

Decker, J.E., and Karl, Susan, 1977, Preliminary aeromagnetic map of the eastern part of southern Alaska: U.S. Geological Survey Open-file Report 77-169-E, scale 1:1,000,000.

De11, C., 1975, Pyrite concretions in sediment from South Bay, Lake Huron: Canadian Journal of Earth Science, v. 15, no. 3, p. 464-465. 
Letterman, R.L., 1963, Kevised stratigraphic nomenclature and age of the Tuxedni Croup in the Cook Inlet region, Alaska, in Geological Survey Research 1963: U.S. Geological Survey Professional Paper 475-C, p. c30-C34.

Detterman, R.L, and Hartsock, J.R., 1966, Geology of the Iniskin-Tuxedri region, Alaska: U.S. Geological Survey Professional Paper 512, 78 p.

Detterman, R.L., Hudson, Travis, Plafker, Ceorge, Tysdal, R.G., and Hoare, J.M., 1976, Reconnalssance geologic map along the Bruin Bay and Lake Clark faults in Kenal and Tyonek Quadrangles, Alaska: U.S. Geological Survey Open-file Report 76-477, 4 p., scale 1:250,000.

Detterman, R.L., Plafker, George, Hudson, Travis, Tysdal, R.G., and Favoni, Nazario, 1974, Surface geology and Holocene breaks along the Susitne segment of the Castle Mountain fault, Alaska: U.S. Geological Survey Miscellaneous Field Studies Map MF-618, scale 1:24,000.

Detterman, R.L., Plafker, George, Tysdal, R.G., and Hudson, Iravis, 1976 , Geology and surface features along part of the Talkeetna segment of the Castle Mountain - Caribou fault system, Alaska: U.S. Geological Survey Miscellaneous Field Studies Map MF-738, scele 1:63,360.

Detterman, R.L., Reed, B.L., and Lanphere, M.A., 1965, Jurassic plutontsm in the Cook Inlet region, Alaska, in Geological Research 1965: U.S. Geological Survey Professional Paper 525-D, P. D16-D21.

1977, Uranium and thorium distribution in continental Tertiary rocks of the Cook Inlet basin and some adjacent areas, Alaska, in Campbell, J.A., ed., Short papers of the U.S. Geological Survey uranium-thorium symposium, 1977: U.S. Geological Survey Circular 753, p. $70-72$.

Dickinson, K.A., 1978, Sedimentary facles in Tertiary rocks in the Tyonek Quadrangle [abs.]: U.S. Geological Survey Professional Paper 1109, p. 84.

Dickinson, K.A., and Campbel1, J.A., 1978, Eplgenetic mineralization and areas favorable for uranium exploration in Tertiary continental sedimentary rock in southcentral Alaska, a preliminary repore: U.S. Geological Survey Open-file Report 78-757, 13 p.

Dobey, P.L., Welch, J., and O'Connor, K.M., 1975, Capps Glacier - Beluga coal economic resource analysis: Fairbanks, Alaska Division of Geological and Geophystcal Surveys, $18 \mathrm{p}$.

Dobrovolny, Ernest, and Schmoll, H.R., 1966, Map of geologic materials, Anchorage and vicinity, Alaska: U.S, Geologlcal Survey Open-file Report $66-25$, scale $1: 24,000$.

1974, Slope-stability map of Anchoroge and vicinity, Alaska: U.S. Geological Survey Miscellaneous Investigations Series Map I-787-E, scale $1: 24,000$. 
Dollhopf, D.J., Hall, W.D., Schafer, W.M., DuPuit, E.J., and Hodder, R.L., 1.978, Selective placement of coal strip mine overburden in Montana: Bozeman, Montana State University, Agricultural Experiment Station, v.1, 109 p.; v.2, 98 p.; v.3, 68 p.; v.4, 55 p.

Duff, P.MCL.D., hallam, A., and Walton, E.K., 1967, Cyclic sedimentâtion: Amsterdam, Elsevier, 280 p.

Eakins, G.R., 1975, Investigations of Alasks's uranium potential, part 1: U.S. Department of Energy Report GJO-1627, 437 p.

Eldridge, G.H., 1900, A reconnaissance in the Susitna basin and adjacent territory, Alaska, in 1898: U.S. Geological survey 20th anrual report, pt. 7, p. $1-29$.

Ethrldge, F.G., Jackson, T.J., and Youngberg, A.D., 1981, Flood-basín sequence of a fine-grained meander belt subsystem, the coal-bearing Lower Wasatch and Upper Fort Union Formations, southern Porder River Basin, Wyoming, in Ethridge, F.G., and Flores, R.M., eds., Recent and ancient nonmatine depositional environments; models for exploration: Society of Economic Paleontologists and Mineralogists Special Publication 31, p, 191-209.

Falini, F., 1965, On the formation of coal deposits of lacustrine origin: Geological Society of America Bulletin, v. 76, p. 1317-1346.

Ferm, J.C., 1974, Carboniferous environmental models in eastern United States and their significance, in Briggs, Garrett, ed., Carboniferous of the southeastern United States: Geological Society of America Special Paper 148, p. 79-95.

Ferrians, 0.J., Jr., 1965, Permafrost map of Alaska: U.S. Geological Survey Miscellaneous Geologic Investigations Map I-445, scale 1:2,500,000.

Feulner, A.J., 1968, Data on wells in the Matanuska-Susitna Borough area, Alaska: U.S. Geological Survey Open-file report, 25 p.

1971, Water-resources reconnaissance of a part of the Matanuska-Susitna Borough, Alaska: U.S. Geological Survey Hydrologic Investigations Atlas HA-364, scale $1: 250,000$.

Fisher, M.A., and Magoon, L.B., 1978, Geologic framework of lower Cook Inlet, Alaska: American Association of Petroleum Geologists Bulletin, v. 62, no. 3. p. 373-402.

Foster, R.L., and Karlstrom, T.N.V., 1967, Ground breakage and associated effects in the Cook Inlet area, Alaska, resulting from the March 27, 1984 earthquake: U.S. Geological Survey Professional Paper 543-E, P. F23.

Freethey, G.W., 1978, Guide to ground-water data, Cook Inlet basin, Alaska: U.S. Geological Survey Open-f1le Report 78-439, $207 \mathrm{p.}$ 
Freethey, G.W., and Scully, D.R., 1980, Water resources of the Cook Iriet basin, Alaska: U.S. Geologic Survey Hydrologic Investigations At las HA-620, scale $1: 1,000,000,4$ sheets.

Eritts, C.E., and Brown, M.E., compilers, 197la, Bibliography of Alaskan geology, 1831-1918: Fairbanks, Alaska Division of Geological and Geophysical Surveys Special Report 21,88 p.

compilers, 1971b, Bibllography of Alaskan geology, 1919-1949:

Fairbanks, Alaska Division of Geological and Geophysical Surveys Special Report 22, 90 p.

compilers, 1971c, Bibliography of Alaskan geology, 1950-59: Fairbanks, Alaska Division of Geological and Geophysical Surveys Special Report 23, 82 p.

comp1lers, 1971d, Bibliography of Alaskan geology, 1960-64: Falrbanks, Alaska Division of Geologlcal and Geophysical Surveys Special Report 24, 81 p.

Fritts, C.E., and Tue11, E.J., compllers, 1972, Bibllography of Alaskan geology, 1965-1968: Falrbanks, Alaska Division of Geological and Geophysical Surveys Special Report 25, $112 \mathrm{p}$.

Fritts, C.E., Zesinger, E.A., Tuell, E.J., and Brown, M.E., compilers, 1972, Bibliography of Alaskan geology, 1969-1971: Fairbanks, Alagka Division of Geological and Geophysical Surveys Special Report 26, 94 p.

Fuchs, W.A., 1980, Tertiary tectonic evolution of the Castle Mounta1n Caribou fault system in the Talkeetna Mountains, Alaska: Salt Lake City, University of Utah unpublished Ph.D. thesis, $152 \mathrm{p}$.

Gates, G.O, 1946, Coal fields of Alaska, In Analyses of Alaska coals: U.S. Bureau of Mines Technical Paper 682, p. 1-9.

1964, Geologic and tectonlc setting, In Mineral and water resources of Alaska: U.S. 88ch Congress, 2nd Session, Senate Committee on Interlor and Insular Affairs, Commercial Print 31-068, p. 32-39.

Gates, G.0., and Gryc, George, 1963, Structure and tectonic h1story of Alaska, In Childs, O.E., and Beebe, B.W., eds., Backbone of the Amertcas: American Association of Petroleum Geolog1sts Memoir 2, p. 264-277.

Gatto, L.W., Merry, C.J., McKim, H.L., and Lawson, D.E., 1980, Environmenta1 analysis of the upper Susitna River basin using Landsat imagery: U.S. Army Corps of Engineers, Cold Regions Research and Engineering Laboratory, $41 \mathrm{p}$.

Gedney, L.D., VanWormer, J.D., and Shapiro, Lewis, 1975, Tectonic Iineaments and plate tectonics in southcentral Alaska: Fairbanks, University of Alaska Geophysical Institute Report, $8 \mathrm{p}$. 
Geer, M.R., and Fennessy, F.D., 1962, Washability of coals from the Matanuska Valley and Beluga River fields, Alaska: U.S. Bureau of Mines Report of Investigations $6017,33 \mathrm{p}$.

Geer, M.R., Sokaski, Michael, and Jacobsen, P.S., 1962, Performance of tables in cleaning Alaska coals: U.S. Bureau of Mines Report of Investigarions $6054,26 \mathrm{p}$.

Gersib, G.A., and McCabe, P.J., 1981, Continental coal-bearing sediments of the Port Hood Formation (Carboniferous), Cape Linzee, Nova Scotia, Canada, 1n Ethridge, F.G., and Flores, R.M., eds., Recent and anclent nommarine depositional environments; models for exploration: Society of Economic Paleontologists and Mineralogists Special Publication 31 , p. $95-108$.

Gingertch, P.D., 1969, Markov analysts of cyclic alluvial sediments: Journal of Sedimentary Petrology, v. 39, no. 1, p. 330-332.

Grantz, Arthur, 1960a, Geologic map of Talkeetna Mountains (A-2) Quadrangle, Alaska, and the contiguous area to the north and northwest: U.S. Geological Survey Miscellaneous Investigations Map I-313, scale 1:48,000.

l960b, Geologic map of Talkeetna Mountains (A-1) Quadrangle and the south third of Talkeetna Mountains (B-I) Quadrangle, Alaska; U.S. Geological Survey Miscellaneous Investigations Map I-314, scale 1:48,000.

Grantz, Arthur, Thomas, Herman, Stern, T.W., and Sheffey, N.B., 1963, Potassium-argon and lead-alpha ages for stratigraphically bracketed plutonic rocks in the Talkeetna Mountains, Alaska, 1n Short papers in geology and hydrology: U.S. Geological Survey Professional Paper 475-B, p. B56-B59.

Grantz, Arthur, Zietz, Isidore, and Andreasen, G.E., 1963, An aeromagnetic reconnaissance of the Cook Inlet area, Alaska: U.S. Geological Survey Professional Paper 316-G, p. 117-134.

Groenewold, G.K., Rehm, B.W., and Cherry, J.A., 1981, Depositional setting and groundwater quality in coal-bearing sediments and spolls in western North Dakota, in Ethridge, F.G., and Flores, R.M., Recent and ancient nonmarine depositional environments; models for exploration: Society of Economic Paleontologists and Mineralogists Special Publication 31, p. 157-167.

Hackett, S.W., 1974, Analyses of fault patterns within and adjacent to the Tordrillo block, southcentral Alaska: Fairbanks, University of Alaska, unpublished paper, 18 p.

1976a, Speculative tectonic evolution of the Cenozoic Shelikof trough, southcentral Alaska, in Short notes on Alaskan geology - 1976: Fairbanks, Alaska Division of Geological and Geophysical Surveys Geologic Report 51, P. 13-18. 
1976b, Regional gravity survey of Beluga basin and adjacent area, Cook Inlet region, southcentral Alaska: Falrbanks, Alaska Division of Geological and Geophysical Surveys Open-file Report 100, 40 p.

1977, Gravity survey of Beluga basin and adjacent area, Cook Inlet region, southcentral Alaska: Fairbanks, Alaska Division of Geological and Geophysical Surveys Geologic Report 49, 26 p., scale 1:250,000, 3 sheets.

1978a, Aeromagnetic map of Talkeetna-Kashwitna River area, Alaska: Falrbanks, Alaska Division of Geologlcal and Geophysical Surveys Open-file Report 107H, scale 1:63,360.

1978b, Preliminary geological interpretation (basement complex) of aeromagnet1c map, Talkeetna-Kashwitna River area, Alaska: Falrbanks, Alaska Division of Geological and Geophysical Surveys Open-file Report $107 \mathrm{~J}$, scale $1: 63,360$.

1978c, Provisional geophysical interpretation of simple Bouguer gravity map, Talkeetna-Kashwitna kiver area, Alaska: Fairbanks, Alaska Division of Geological and Geophysical Surveys Open-file Report 107I, scale $1: 63,360$.

1978d, Simple Bouguer gravity map of Talkeetna-Kashwitna River area, Alaska: Fairbanks, Alaska Division of Geological and Geophystcal Surveys Open-file Report 107G, scale $1: 63,360$.

Hacquebard, P.A., and Donaldson, J.R., 1969, Carboniferous coal deposition assoclated with flood-platn and limnle environments in Nova Scotid, in Dapples, E.C., and Hopkins, N.E., eds., Environments of coal deposition: Geological Soctety of America Special Paper 114, p. 143-191.

Hamilton, P.A., White, D.H., JY., Matson, T.K., 1975, The reserve base of U.S. coals by sulfur contenc, pt. 2, The Nestein States: U.S. Bureau of Mines Information Circular 8693,322 .

Hartman, D.C., Pessel, G.H., and McGee, D.L., 1972, Preliminary report on the stratigraphy of the Kenal Group, upper Cook Inlet, Alaska: Falrbanks, Alaska Division of Geological and Geophysical Surveys Special Report 5 , scale 1:500,000, Il sheets.

1974, Kenal Group of Cook Inlet basin, Alaska: Falrbanks, Alaska Division of Geologlcal and Geophysical Surveys Open-file Report 49, 5 p., scale $1: 500,000,11$ sheets.

Hawley, C.C., 1973, Geology and mineral deposits of the Chulitna-Yentna mineral belt, Alaska: U.S. Genlogical. Survey Professional Paper 758-A, 10 p.

1978. Mineral appraisal of lands adjacent to Mt. Mckinley National Park, Alaska: U.S. Bureau of Mines Open-file Report 24-78, 274 p.

Hawley, C.C., and Clark, A.L., 1968, Occurrences of gold and other metals in the Upper Chulitna district, Alaska: U.S. Geological Survey Circular 564, $21 \mathrm{p}$. 
1974, Geology and mineral deposits of the Upper Chulitna district, Alaska: U.S. Geological Survey Professional Paper 758-B, 47 p.

Hawley, C.C., Clark, A.L., Herdrick, M.H., and Clark, S.H.B., 1969, Results of geological and geochemical investigations in an area northwest of the Chulitna River, central Alaska Range: U.S. Geological Survey Circular $617,19 \mathrm{p}$.

Hayes, J.B., Harms, J.C., and Wilson, T., Jr., 1976, Contrasts between bralded and meandering stream deposits, Beluga arid Sterling Formations (Tertiary), Cook Inlet, Alaska, in Recent and ancient sedimentary environments in Alaska: Alaska Geological Society Symposium, Anchorage, Apri1 2 4, 1975, Proceedings, p. J1-J27.

Hennagin, B.D., 1978, Cook Inlet coal: Economics of mining and marine siury transport: U.S. Bureau of Mines Open-flle Report 17(2)-78, 79 p.

Herre1d, Gordon, 1964, Tectontes and ore deposits in Alaska: American Institute of Mining Engineers Conference, College, Alaska, March 19, 1964, Proceedings, $7 \mathrm{p}$.

Heward, A.P., 1978, Alluvial fan and lacustrine sediments from the Stephanian $A$ and $B$ (La Magdalena, Cineramatallana and Sabero) coalfields, northern Spa1n: Sedimencology, v. 25, p. 451-488.

H1ckman, R.G., 1974, Structural geology and stratigraphy along a segment of the Denalf fault system: Madison, University of Wisconsin unpublished Ph.D. thesis, $276 \mathrm{p}$.

Hinckley, T.K., Smich, K.S., Peatd, J.L., and Tompk1ns, M.L., 1982, whole-rock chemical composition of some samples from two drill-hole cores in the Capps coal fleld, Beluga coal area, southcentral Alaska: U.S. Geological Survey Open-file Report 82-672, 50 p.

Hite, D.M., 1976, Some sedimentary aspects of the Kenai Group, Cook Inlet, Alaska, in Recent and ancient sedimentary environments in Alaska: Alaska Geological Society Symposium, Anchorage, 1976, Proceedings, p. Il-I23.

Hollick, Arthur, 1936. The Tertiary floras of Alaska: U.S. Geolog1cal Survey Professional Paper 182, 185 p.

Hollock, C.A., 191 la, Discussion of the Cretaceous and Tertiary floras of Alaska [abs.]: Washington Academy of Science Journal, v. 1, p. 142.

1911b, Results of a preliminary study of the so-called Kenai flora of Alaska: American Journal of Sclence, 4th series, v. 3l, p. 327-330.

Holloway, C.D., 1977, Map showing coal fields and distribution of coal-bearing rocks in the eastern pert of southern Alaska: U.S. Geological Survey Operi-file Report 77-169D, scale $1: L, 000,000$. 
Hopk1ns, D.M., 1951, Lignite deposils near Broad Pass station, Alaska, in Coal invest1gations in southcentral Alaska, 1944-46: U.S. Geological Survey Bulletin 963-D, P. 187-191.

Horne, J.C., Ferm, J.C., Carucc1o, F.T., and Baganz, B.P., 1978, Depositional models in coal exploration and mine planning, Appalachian region: American Association of Petroleum Geolog1ste Bulletin, v. 62, no. 12, p. 2379-2419.

Howel1, D.J., and Feral, J.C., 1980, Exploration model for Pennsylvanian upper delta plain coals, southwest West Virginia: American Association of Petroleum Geologists Bulletin, v. 64, no. 6, p. 938-941.

Hutcheon, R.J., 1972, Sea ice conditions in the Cook Inlet, Alaska, during the 1970-71 winter: National Oceanic and Atmospheric Administration Technology Memoir AR-7, $17 \mathrm{p}$.

International Committee on Coal Petrology, 1963, International handbook for coal petrography, 2nd edition: Paris Centre National De La Recherche Scientifique, pages unnumbered,

Jacobsen, S.I., Aamodt, P.L., and Sharp, R.R., Jr., 1979, Uranium hydrogeochemical and stream sediment reconuaissance of the Lime hills and Tyonek NTMS Quadrangles, Alaska, Including concentrations of forty-three additional elements: U.S. Department of Energy Report GJBX-29(79), 224 p.

Joint Federal-State Land-Use Planning Commission for Alaska, 1974, Inventory report--minerals, energy, and geology, southcentral region, Resource Plamning Team: Anchorage, U.S. Geological Survey, p. 46-96.

Jones, D.L., 1973, Structural elements and biostratigraphical framework of lower Cretaceous rocks in southern Alaska, in the Boreal lower Cretaceous: Liverpool, England, Seel House Press, p. 1-18.

Jones, D.L., and Sibberling, N.J., 1979, Mesozolc stratigraphy---The key to tectonic analysis of southern and central Alaska: U.S. Geologlcal Survey Open-file Report 79-1200, 41 p.

Jones, D.L., Silberling, N.J., Csejtey, Bella, Jr., Nelson, W.H., and Blome, C.D., 1980, Age and structural signiflcance of ophiolite and adjoining rocks in the upper Chulitna district, southcentral $A$ laska: U.S. Geological Survey Professional Paper 1121-A, 21 p.

Karlstrom, T.N.V., 1955, Late Pleistocene and recent glacial chronology of southcentral Alaska (Cook Inlet region): Geological Society of America Bulletin, v. 66, no. 12, pt. 2, p. 1581-1582.

Karlstrom, T.N.V., 1960, The Cook Inlet, Alaska, glacial record and Quaternary classification, in Geological Research 1960: U.S. Geological Survey Professional Paper 400-B, p. B330-B332.

1964, Quaternary geology of the Kenal lowland and glacial history of the Cook Inlet region, Alaska: U.S. Geological Survey Professional Paper 443, 69 p. 
1965, Resume of the Quaternary geology of the upper Cook Inlet area and Matanuska River valley, in Pewe, T.L., ed., Cuidebook to the Quaternary geology, central and southcentral Alaska, International Assoclation for Quaternary Research, 7th Congress, Lincoln, Nebraska Acadeny of Science (Reprinted by Alaska Division of Geological and Geophysical Surveys p. 114- 141).

Karlstrom, T.N.V., Coulter, H.W., Fernald, A.T., Williams, J.R., HopkIns, D.M., Pewe, T.L., Drewes, Harold, Muller, E.H., and Condon, W.H., 1964, Surficlal geology of Alsska: U.S. Geological Survey riiscellaneous Geologic Investigations Map I 357, scale 1:J,584,000.

Karmasin, K. von, 1952. Deutung des Frazieswechsel in den Fläzen Erda und Agir auf Grund mikropetrographischer Schlitzprobenuntersuchungen (The meaning of facies changes in the coal seams Erda and Agir on the basis of micropetrographic analysis of exploration samples]: Berlin, Bergbau Archiv [Mining Archives]13, Heft [Article] 1-2, p. 74-100.

Kelly, T.E., 1963, Geology and hydrocarbons in Cook Inlet basin, Alaska, In Childs, O.E., and Beebe, B.W., eds.. Backbone of the Americas - a symposium: American Association of Petroleum Geologists Memoir 2, P. $278-296$.

Kirschner, C.E., and Lyon, C.A., 1973, Stratigraphic and tectonic development of Cook Inlet petroleum province, in Pitcher, M.G., ed., Arctic Geology: American Association of Petroleum Geologists Memolr 19, p. 396-407.

Kline, J.T., 1978, Approximate slope map of the Talkeetna-Kashwitna area, Susitna River basin, Alaska: Falrbanks, Alaska Division of Geological and Geophysical Surveys Open-file Report 107C, scale 1:63,360.

Laird, A.M., 1977, Beluga field potential - proposed coal operations, in McConkey, W.C., chairman, Alaska coal and the Paciflc conference, Juneau, Proceedings: Alaska Department of Commerce and Economic Development and U.S. Energy Research and Development Administration report, p. 143-152.

Leco Corporation, 1975, Instruction manual for titrators: St. Joseph, Mich1gan, $51 \mathrm{p}$.

LKB Resources, Inc., 1978, Bibliography NURE aerial gamma-ray and magnetic reconnaissance survey, Cook Inlet, Alaska area, Tyonek, Kenai, Seldovia, Anchorage, Seward, Blylng Sound Quadrangles: Grand Junction, CO., U.S. Department of Energy Report, GJBX-108(78), variously paginated.

Lockhart, Dercy, 1979, Susitna River basin resource bibliography, supplement 1979: Anchorage, Alaska Department of Natural Resources Division of Research and Development, $244 \mathrm{p}$.

Lyle, W.M., and Bragg, N.J., 1974, Coal bibliagraphy of Alaska: Fairbanks, Alaska Division of Geological and Geophysical Surveys Open-file Report $41,31 \mathrm{p}$. 
Mackevett, E.M., Jr., Singer, D.A., and Holloway, C.D., 1978, Maps and tables describing metalifferous mineral resource potential of southern Alaska: U.S. Geologlcal Survey Open-file Report 78-1-E, 45 p., scale 1:1,000,000.

MacNe1], F.S., Wolfe, J.A., Miller, D.J., and Hopkins, D.M., 1961, Correlation of Tertiary formations of Alaska: American Assoclation of Petroleum Geologists Bulletín, v, 45, no. 11, p. 1801-1809.

Magoon, L.B., Adk1son, W.L., and Egbert, K.M., 1976, Map showing geology, wildcat wells, Tertiary plant fossil localities, K-Ar age dates, and petroleum operations, Cook Inlet area, Alaska; U.S. Geological Survey Geologic Invest1gations Map I-1019, scale 1:250,000.

Magoon, L.B., and Claypool, G.E., 1981, Petroleum geology of Cook Inlet basin---an exploration model: American Association of Petroleum Geologists Bulletin, v. 65, no, 6, p. 1043-1061.

Maher, J.C., and Trollman, W.M., 1969, Geological literature on the Cook Inlet basin and vicinity, Alaska: Fairbanks, Alaska Division of Geological and Geophysical Surveys Special Report 18, published in cooperation with the U.S. Geological Survey, 82 p.

Naloney, R.P., 1958, Reconnaissance of the Beluga River coal field, Alaska: U.S. Bureau of Mines Report of Investigations $5430,18 \mathrm{p}$.

Martin, G.C., 1926, The Mesozoic stratigraphy of Alaska: U.S. Geological Survey Bulletin 776, p. 232-240.

MartIn, G.C., and Katz, F.J., 1912, Geology and coal fields of the lower Matanuska Valley, Alaska: U.S. Geological Survey Bulletin 500, 98 p.

Mason, Brian, 1966, Princlples of geochemistry: New York, Wiley and Sons, p. 241-243.

May, R.R., and Warfield, R.S., 1957, Investigation of subbituminous-coal beds near Houston, westward extremity of Matanuska coal fleld, Alaska: U.S, Bureas of Mines Report of Investigations $5350,20 \mathrm{p}$.

McConkey, W., Lane, D., Qu1nlan, C., Rahm, M., and Rutledge, G., 1977, Alaska's energy resources; final report, phase 1, v. 2, Inventory of ot1, gas, coal, hydroelectric and uranium resources: Anchorage, Alaska Division of Energy and Power Development report under contract EY76C-06-2435 from U.S. Department of Energy, p. 9l-216.

McGee, D.L., 1973, Coal reserve study---Chultna-Beluga-Capps area, Alaska: Falrbanks, Alaska Division of Geological and Geophysical Surveys Open-file Keport 30, 5 p., scale 1:63,360, 4 sheets.

1977. Alaskan coal - An overview, in McConkey, W.C., cha1rman, Alaska coal and the Pacific conference, Juneau, Praceedings: Alaska Department of Commerce and Economic Development and U.S. Energy Research and Development Administration report, p. 36-51. 
1978, Bedrock geology and coal occurrences, Talkettna-Kashwitna area, Susitna River basin: Falrbanks, Alaska Division of Geological and Geophysical Surveys Open-file Report 107E, scale 1:63,360.

McGee, D.L., and Emmel, K.S., 1979, Alaska coal resources: Falrbanks, Alaska Division of Geological and Geophysical Surveys unpublished report, $26 \mathrm{p}$.

McGee, D.L., EmmeI, K.S., Coonrod, P.L., and Clautice, K.H., 1977, Blbllography of the Cook Inlet, 1969-1976: Fairbanks, Alaska Division of Geological and Geophysical Surveys Special Report 27, 33 p.

McGee, D.L., and Henning, M.W., 1977, Reconnalssance geology, southcentral Talkeetna Mountains, Alaska: Fafrbanks, Alaska Division of Geological and Geophysical Surveys Open-f1le Report 103, scale $1: 63,360$.

McGee, D.L., and O'Connor, K.M., 1975, Mineral resources of Mlasks and the impact of federal land policles on their availability - coal: Fairbanks, Alaska Division of Geological and Geophysical Surveys Open-file Report 51,29 p.

1975, Cook Inlet basin subsurface coal reserve study: Fairbanks, Alaska Division of Geological and Geophysical Surveys Open-file Report 74, 24 p. scale 1:500,000, 3 sheets.

Merritt, R.D., 1982, Framboldal pyrites in Tertiary continental-tiluvial coals of southcentral Alaska: University of Alaska School of Mineral Industry, Portal, v. 3, p. 5-6.

1983, Coal overburden; geological characterization and promine planning: Park Ridge, New Jersey, Noyes Data Corporation Energy Technology Review No. 88, $343 \mathrm{p}$.

Merritt, R.D., Eakins, G.R, and Clough, J.G., 1982, Coal investigation of the Susitna lowland: Falrbanks, Alaska Divislon of Geological and Geophysical Surveys Open-file Report 142, 89 p., scale 1:250,000, 4 sheets.

Mertie, J.B., Jr., 1919, Platinum-bearing gold placers of the Kahilena Valley: U.S. Geological Survey Bulletin 692-D, p. 233-264.

Miller, D.J., Payne, T.G., and Gryc, George, 1959, Geology of possible petroleum provinces in Alaska: U.S. Geological Survey Bulletin 1094, 127 p.

Miller, R.D., and Dobrovolny, Ernest, 1959, Surficial geology of Anchorage and vicintty, Alaska: U.S. Geological Survey Bu1letin 1093, 128 p.

Miller, T.P., ed., 1976, Recent and anctent sedimentary erivironments in Alaska: Alaska Geological Soclety Symposium, Anchorage, Apríl 2-4, 1975, Proceedings, p. I1-I23, J1-J27.

Mitchell, G.A., Micchell, W.W., and McKendrick, J.D., 1981, Soll characterization of Alaskan coal mine spoils, in Rao, P.D., and Wolff, E.N., eds., Focus on Alaska's Coal '80: Alaska Coal Conference, 2nd, Fairbanks, 1980, Proceedings, Fairbanks, University of Alaska Mineral Industry Research Laboratory Report 50, p. 412-417. 
Moffitt, F.H., and Pogue, J.E., 19L5, The Broad Pass region: U.S. Geological Survey Bulletin 608,80 p.

Nulligan, J.J., Warfield, R.S., and Wells, R.R., 1967, Sampling a gold-copper deposit, Golden Zone Mine, southcentral Alaska: U.S. Bureau of Mines Open-file Report 9-67, 59 p.

Naske, C.M., and Triplehorn, D.M., 1980, The Federal government and Alaska's coal: Fairbanks, University of Alaska, The Northern Engineer, v. 12, no. 3, p. $11-13$.

National Weather Service, 1973, [Map of] Alaska [showing] mean annual precipitation: U.S. Department of Commerce National Weather Service in cooperation with U.S. Geological Survey, Anchorage, scale 1:2,500,000,

Nelson, G.L., 1981, Groundwater reconnalssance near Granite Point, Alaska, in Rao, P.D., and Wolfr, E.N., eds., Focus on Alaska's Coal '80: Alaská Coal Conference, 2nd, Falrbanks, 1980, Proceedings, Ealrbanks, University of Alaska Mineral Industry Research Laboratory Report 50, p. 127-133.

Nelson, S.W., and Reed, B.L., 1978, Surficlal deposits, Talkeetna Quadrangle, Alaska: U.S. Geological Survey Miscellaneous Field Studies Map MF-870J, scale $1: 250,000$.

Osvald, H., 1937, Vyrar och myroding [Peatlands and their cultivation]: Stockholm, Kooperativa Forbundels Bokforlag, $407 \mathrm{p}$.

Page, R.A., and Lahr, J.C., 1971, Measurement of Eault slip on the Denal1, Fairweather and Castle Mountain faults, Alaska: Journal of Geophysical Research, v. 76, no. 35, P. 8534-8543.

Patsch, B.J.G., 1976, Exploration and development of the Beluga coal field, in Rao, P.D., and Wolff, E.N., eds,. Focus on Alaska's Coal, '75: Alaska Cosl Conference, lst, Fairbanks, 1975, Proceedings, Fairbanks, University of Alaska Mineral Industry Research Laboratory Report 37, p. 72-83.

1977, Beluga field potential - the resource, in McConkey, W.C., chatrman, Alaska coal and the Pacific, Juneau, Proceedings: Alaska Department of Commerce and Economic Development and U.S. Energy Research and Development Administration report, p. 126-142.

Payne, T.G., 1955, Mesozoic and Cenozoic tectonic elements of Alaska: U.S. Geological Survey Miscellaneous Geologic Investigations Map I-84, scale $1: 5,000,000$.

Péwe, T.L., ed., 1965, Guidebook to the Quaternary geology, central and southcentral Alaska, International Association for Quaternary Research, 7 th Congress, USA, 1965: Lincoln Nebraska Academy of Science (reprinted by Alaska Divislor of Cleological and Geophysical Surveys 14 l p.).

Péwe', T.L, 1975, Quaternary geology of Alaska: U.S. Geological Survey Professlonal Paper $835,145 \mathrm{p}$. 
Placer Amex, Inc., 1976, Beluga (an Alaskan coal field, not a whale): Calgary, Alberta, Canada, Western Miner, Oct. 1976, p. 82-84.

1977, Beluga coal project status report: San Francisco, California, Placer Amex, Inc., $58 \mathrm{p}$.

1979, Beluga coal project status report: San Erancisco, California, Placer Amex, Inc., $63 \mathrm{p}$.

Plafker, George, 1971, Pac1fic margin Tertlary basin, in Future petroleum provinces of North America: American Association of Petroleum Geologists Memoir 15, p. 120-135.

Post, Austin, and Mayo, L.R., 1976, Glacler dammed lakes and outburst floods in Alaska: U.S. Geological Survey Hydrologic Investigations Atlas HA-455, 10 p., scale $1: 1,000,000,3$ sheets.

Price, N.B., and Duff, P.McL.D., 1969, Mineralogy and chemistry of tonsteins from Carboniferous sequences in Great Britaln: Sedimentology, v. 13, no. 1, p. 45-69.

Race, W.H., 1962, The mineral industry of the Kena1 - Cook Inlet - Sustina region: Falrbanks, Alaska Division of Geological and Geophysical Surveys report, $42 \mathrm{p}$.

Ralston, D.S., and Wiram, V.P., 1978, The need for selective placement of overburden and equipment considerations: Mining Congress Journal, v. 84, no. 1, p. 18-24.

Ramsey, J.P., 1981a, Chujtna coal ls wafting on market; Alaska Industry, May 1981, p. 12.

1981b, Geology, coal resources, and mining plan for the Chuitna River Eleld, Alaska, in Rao, P.D., and Wolff, E.N., eds., Focus on Alaska's Coal '80: Alaska Coal Conference, 2nd, Fafrbanks, 1980, Proceedings, University of Alaska Mineral Industry Research Laboratory Report 50, p. 111-121.

Rao, P.D., 1976, Charactertzation of Alsskan coals, in Rao, P.D., and Wolff, E.N., eds., Focus on Alaska's coal - 1975: Alaska Coal Conference, lst, Falrbanks, 1975, Proceedings, University of Alaska Mineral Industry Research Laboratory Report 37, p. 33-47.

Rao, P.D., and Wolff, E.N., 1980, Characterization and evaluation of washability of Alaskan coals; selected seams from northern Alaska, Broad Pass, L1ttle Tonzona, Tramuay Bar, Beluga, Yentna, Kena1, and Nenana coal fields: U.S. Department of Energy Final Technical Report for phase II, July 1977 - February 1979, Report DOE/ET/13350/-T2, 47 p.

1981, Petrographic, mineralogical and chemical characterization of certaln Alaskan coals and washability products, j.n Rao, P.D., and Wolfe, E.N., eds., Focus on Alaska's Coal 180: Alaska Coal Conference, 2nd, Falrbanks, 1980, Proceedings, University of Alaska Mineral Industry Research Laboratory Report 50, p. 194-235. 
Reed, B.L., 1973, Plutonic rocks of the Alaska-Aleutian Range batholith, in Pitcher, M.G., ed., Arctic Geology: American Association of Petroleum Geologiets Memoir 19, p. 421 428.

Reed, B.L., and Elliott, R.L., 1970, Reconnaissance geologic map, analyses of hedrock and stream sediment samples and an aeromagnetic map of parts of the southern Alaska Range: U.S. Geological Survey Open-file Report $70-271,145$ p., scale $1: 250,000$.

Reed, B.L., and Lanphere, M.A., 1969, Age and chemistry of the Mesozoic and Tertlary plutonic rocks in southcentral Alaska: Geological Society of America Bulletin, v. 80 , no. 1, p. 23-44.

Reed, B.L., and Miller, T.P., 1980, Uranium and thorium content of some Tertiary granitic rocks in the southern Alaska Range: U.S. Geological Survey Open-file Report 80-1052, 16 p.

Reed, B.L., and Nelson, S.W., 1980, Geologic map of the lalkettna Quadrangle, Alaska: U.S. Geological Survey Geologic Investigations Map I-1174, scale $1: 250,000$.

Reed, J.C., Jr., 1961, Geology of the Mount Mckinley Quadrangle, Alaska: U.S. Geological Survey Bulletin L108-A, 36 p., scale 1:250,000.

Reger, K.D., 1978, Reconnalssance geology of the Talkeetna-Kashwitna area, Susitna River basin, Alaska: Falrbanks, Alaska Division of Geological and Geophysical Survej's Open-file Report 107A, scale 1:63,360.

Reger, R,D., and Carver, C.L. 1978a, Reconnaissance geology of the new capital site and vicinity, Anchorage Quadrangle, Alaska: Fairbanks, Alaska Division of Geological and Geophysical Surveys Open-file Report 113A, scale 1:63,360.

1978b, Reconnaissance geologic materials map of the new capttal site and vicinity, Anchorage Quadrangle, Alaska: Falrbanks, Alaska Division of Geological and Geophysical Surveys Open-file Report 1135, scale $1: 63,360$.

1978c, Reconnaissance geologic materials map, Talkeetna-Kashwitna area, Susltna River basin, Alaska: Fairbanks, Alaska Division of Geologtcal and Geophysical Surveys Open-file Report 107B, scale 1:63,360.

Reineck, H.E., and Singh, I.B., 1975, Depositional sedimentary environments: New York, Springer-Verlag, 439 p.

Richards, G.H., 1974, Tectonic evolution of Alaska: American Association of Petroleum Geologists Bulletin, v. 58, no. 1, p. 79-105.

Richter, D.H., 1963, Geology of the Portage Creek - Susitna River area: Fairbanks, Alaska Division of Geologjcal and Geopliysical Surveys Geologic Report 3, scale 1:24,000, 2 sheets. 
Robinson, G.D., Wedow, H, Jx, and Lyons, J.B., 1955, Radioactivity investigations in the Cache Creek area, Yentna district, Alaska, 1045: U.S. Geological Survey Bulletin 1024-A, 23 p.

Ross, C.P., 1933, Mineral deposits near the West Fork of the Chulitna River, Alaska: U.S. Geological Survey Bulletin 849-E, p. 289-333.

Rutledge, F.A., Thorme, R.L., Kerns, W.H., and Mulligan, J.J., 1953, Preliminary report - nonmetallic deposits accessible to the Alaska Railroad as possible sources of raw matertals for the construction industry: U.S. Bureau of Mines Report of Investigations 4932, $129 \mathrm{p}$.

Ryer, T.A., 1981, Deltalc coals of Ferron Sandstone Member of Mancos Shale; predictive model for Cretaceous coal-bearing strata of Western Interior: American Association of Petroleum Geologists Bulletin, v. 65, no. 11, p. $2323-2340$.

Sanders, R.B., 1976, Coal resources of Alaska, in Rao, P.D., and liclff, E.N., editors, Focus on Alaska's Coal 175: Alaska Coal Conference, 1st, Fairbanks, October 15-17, 1975, Proceedings, University of Alaska Mineral Industry Research Laboratory Report 37, p. 21-32.

1981, Coal resources of Alaska, in Rao, P.L., and Wolff, E.N., cds., Focus on Alaska's Coal '80: Alaska Coal Conference, 2nd, Fairbanks, 1980, Proceedings, University of Alaska Mineral Industry Research Laboratory Report 50, p. 11-31.

1982, Coal resources of Alaska, in Alaska's oil/gas and minerals industry: Alaska Geographic Quarterly, v. 9, no. 4, p. 146-165.

Sandoval, F.M., and Gould, W.L., 1978, Improvernent of saline- and sodium-affected disturbed lands, in Schaller, F.W., and Sutton, Paul, eds., Reclamation of drastically disturbed lands: ASA-CSSA-SSSA (American Society of Agronomy - Crop Science Society of America - Soll Science Society of America), Madison, 1978, Proceedings, p. 485-504.

Schaff, R.G., 1980, Geologic characteristics of Alaskan coal deposits, in Surface coal mining in Alaska, by the Committee on Alaskan Coal Mining and Reclamation (COACMAR): Washington, D.C., National Academy Press, p. $12-13$.

Schaff, R.G., and Merritt, R.D., 1983, Alaska's coal provinces and resources, In International Conference on Coal, Minerals, and Petroleum, 2nd, Anchorage, February 16-17, 1983, Proceedings: Resource Development Council for Alaska, Inc., p. 157-161.

Schmol1, H.R., Chleborad, A.F., Yehle, L.A., Gardner, C.A., and Pasch, A.D., 1981, Reconnaissance engineering geology of the Beluga coal resource area, southcentral Alaska, in Rao, P.D., and wolff, E.N., eds., Focus on Alaska's Coal '80: Alaska Coal Conference, 2na, Fairbanks, 1980, Proceedings, Falrbanks, University of Alaska Mineral Industry Research Laboratory Report 50, p. 92-110. 
Schmoll, H.R., and Yehle, L.A., 1978, Generalizedi physiography and geology of the Beluga coal field and vicinity, southcentral Aleska, in Johnson, K.M., ed., The U.S. Geological Survey in Alaska - accomplishments auring 1977: U.S. Geological Survey Circular 772-B, P. B73-B76.

Schmoll, H.R., Yehle, L.A., and Gardner, C.A., 1981, Preliminary geologic inap of the Congahbuna area, Cook Inlet region, Alaska: U.S. Geological Survey Open-file Report 81-429, 8 p., scale 1:63,360.

Selkregg, L.L., ed., 1976, Alaska regional profiles, southcentral region: Fairbanks, University of Alaska Arctic Environmental Information and Data Center, $255 \mathrm{p}$.

Selvig, W.A., Ode, W.H., and Davis, J.D., 1944, Low temperature carbonizatjon of Alaska coals: U.S. Bureau of Mines Technical Paper 668, $16 \mathrm{p}$.

Sharma, G.D., and Burre11, D.C., 1970, Sedfmentary environment and sediments of Cook Inlet, Alaska: American Association of Petroleum Geologists Bulletin, v. 54, no. 4, p. 647-654.

Singer, D.A., Csejtey, Bella, Jr., and Miller, R.J., 1978, Map and discussion of the metalliferous and selected nonmetalliferous mineral resources of the Talkeetna Mountalns Quadrangle, Alaska: U.S. Geological Survey Open-f1le Report 78-558-Q, 32 p., scele 1:250,000.

Smith, P.S., 1939, Areal geology of Alaska: U.S. Geological Survey Professional Paper 192, 100 p.

Sobek, A.A., Schuller, W.A., Freeman, J.R., and Smith, R.M., 1978, Field and laboratory methods applicable to overburdens and minesoils: Cincinnati, Industrial Environmental Research Laboratory, U.S. Environmental Protection Agency, 302 p.

Spackman, Willlam, Davis, Alan, and Mitchell, G.D., 1976. The fluorescence of liptinlte macerals: Provo, Brigham Young University Geologlcal Study 22, part 3, p. 59-75.

Spears, D.A., 1973, Relationship between exchangeable cations and paleosalinity: Geochimica et Cosmochimica Acta, v. 37, no. 1, p. 77-85.

1974. Relationship between water-soluble cations and paleosalinity: Geochimica et Cosmochimica Acta, v. 38, no. 4, p. 567-575.

Spears, D.A., and Kanaris-Sotiriou, R., 1979, A geochemical and mineralogical investigation of some British and other European tonsteins: Sedimentology, v. 26, no. 3, p. 407-425.

Spurr, J.E., 1900, A reconnaissance in southwestern Alaska in 1898: U.S. Geological Survey 20th Annual Report, pt. 7, p. 31-268.

Stach, E., Mackowsky, M.T., Teichmuller, M., Taylor, A.H., Chandra, D., and Telchmiller, K., 1975, Stach's textbook of coal petrology: Berlin, Gebruder Borntraeger, 428 p. 
Steele, W.C., and LeCompte, J.R., 1978, Map showing Interpretation of LANDSAT imagery of the Talkeetna Mountains Quadrangle, Alaska: U.S, Geological Survey Open-file Report 78-558D, scale 1:250,000, 2 sheets.

Stene, L.P., 1979, Polyframboldal pyrite in the tills of southwestern Alberta: Canadian Journal of Earth Sciences, v. 16, no. 10, p. 2053-2057.

St1ll, P.J., 1980, Index of streamflow and water-quality records to September 30, 1978, southcentral Alaska: U.S. Geologica1 Survey Open-file Report $80-600,54 \mathrm{p}$.

Stone, R.W., 1906, Coal flelds of the Kachemak Bay region: U.S. Geological Survey Bulletin 277, p. 53-73.

Sweeney, R.E., and Kaplan, I.R., 1973, Pyrite framboid formation; laboratory synthests and marine sediments: Economic Geology, v. 68, no, 5, p. 618-634.

Sw1ft, W.H., Haskins, J.P., and Scott, M.J., 1980, Beluga coal market study: Richlend, Washington, Battelle Northwest Laboratories report preparea for the State of Alaska Division of Policy Development and Planning, $53 \mathrm{p}$.

Thiessen, R., 1920, Compilation and composition of bituminous coals: Journal of Geology, v. 28, no. 3, p. 185-209.

Ting, T.F.C., 1978, Petrographic techniques in coal analysis, in Karr, Clarence, Jr., ed., v. 1 of Amalytical methods for coal and coal products: New York, Academlc Press, p. 3-26.

Toenges, A.L., and Jolley, T.R., 1949, Investigations of cool deposits in southcentral Alaska and the Kenal Peninsula: U.S. Bureau of Mines Report of Investigations $4520,37 \mathrm{p}$.

Triplehorn, D.M., 1976, Contributions to clay mineralogy and petrology, Cook Inlet basin, Alaska: Fairbanks, Alaska Division of Geologlcal and Geophysical Surveys Open-file Report 102, $18 \mathrm{p}$.

Triplehorn, D.M., Turner, D.L., and Naeser, C.W., 1977, K-Ar and fission-track dating of ash partings in Tertlary coals from the Kenat Peninsula, Alaska; a radiometric age for the Homerian-Clamgulchian stage boundary: Geological Society of America Bullet1n, v. 88, no. 8, p. 1156-1160.

Tuck, Ralph, 1934, The Curry district, Alaska: U.S. Geological Survey Bulletin 857, P. 99-140.

Turner, D.L., Triplehorn, D.M., Naeser, C.W., and Wolfe, J.A., 1980, Radlometric age dating of ash partings in Alaska coal beds and upper Tertlary paleobotanical stages: Geology, v. 8, no. 2, p. 92-96.

U.S. Army Corps of Englneers, 1972, Flood plain information, Talkeetna River, Susitna River, Chulitna River: Report for the Matanuska-Susitna Borough, $28 \mathrm{p}$. 
U.S. Department of Agrlculture, 1954, Diagnosis and improvement of saline and alkalf solls: U.S. Department of Agriculture Handbook 60, $160 \mathrm{p}$.

U.S. Department of Commerce, 1968, Climates of the states - Alaska: Environment and Sclence Services Administration, Climatography of the U.S. Report 60-49, $23 \mathrm{p}$.

U.S. Department of knergy, 1979, Beluga coal field development, social effects and management alternatives: Richland, Washington, Battelle Pacific Northwest Laboratory report for State of Alaska Department of Commerce and Economic Development under contract PNL-RAP-29/UC11, $102 \mathrm{P}$.

U.S. Geological Survey, 1954, Tslkeetna Mountains Quadrangle, Alaska: United Staces Geological Survey Alaska Topography Sertes Map, scale l:250,000.

1958a, Talkeetna Quadrangle, Alaska: U.S. Geological Survey Alaska Topographic Series Map, scale 1:250,000.

1958b, Tyonek quadrangle, Alaska: U.S. Geological Survey Alaska Topographic Series Map, scale 1:250,000.

1962, Anchorage Quadrangle, Alaska: U.S. Geological Survey Alaska Topographic Series Map, scale 1:250,000.

1972, The status of mineral resource information on the major land withdrawals of the Alaska Native Claims Setclement Act of 1971: U.S. Geological Survey Open-file Report 546-G, 164 p.

U.S. Geological Survey, 1976, Coal-resource classification system of the U.S. Bureau of Mines and U.S. Geologlcal Survey: U.S. Geological Survey Bulletin 1050-B, p. Bl-B6.

Van Wormer, J.D., Davies, J.N., and Gedney, L.D., 1974, Selsmicity and plate tectonics in souchcentral Alaska: Seismological Society of America Bulletin, v. 64, P. 1467-1475.

Wahrhaft1g, Clyde, 1965, Physlographic divisions of Alaska: U.S. Geologica1 Survey Professional Paper 482, 52 p., vartous scales, 6 sheets.

Walker, F.K., 1975, B1bliography and index of U.S. Geological Survey publications relating to coal, January 1971-June 1974: U.S. Geological Survey Circular 709, $14 \mathrm{p}$.

Warfield, R.S., 1962, Investigation of a subbituminous coal deposit sultable for open cut mining, Beluga River coal field, Alaska: U.S. Bureau of Mines Report of Investigations 6238, $100 \mathrm{p}$.

Waring, G.A., 1947, Nonmetalliferous deposits in the Alaska Railroad belt: U.S. Geological Survey Circular 18, 10 p.

Weber, F.R., 1961, Reconnalssance engineering geology for selection of highway route from Talkeetna to McGrath, Alaskai U.S. Geological Survey Open-file Map 61-169, scale 1:250,000, 2 sheets. 
Willams, E.G., and Kelth, M.L., 1963, Relationship between sulfides in coals and the occurrence of marine roof beds: Economic Geology, v. 58, no. 5, p. 720-729.

Williams, J.R., 1970, Ground water in the permafrost regions of Alaska: U.S. Geological Survey Professional Paper 696, 83 p.

Wiliams, V.E., and Ross, C.A., 1979, Depositional setting and coal petrology of Tulameen coalfield, southcentral British Columbia: American Assoclation of Petroleum Geologists Bulletin, v. 63, no. 1l, p. 2058-2069.

Wolfe, J.A., 1966, Tertiary plants from the Cook Inlet region, Alaska: U.S. Geological Survey Professional Paper 398-B, P. Bl-B32.

1972, An interpretation of Alaskan Tertiary floras, in Graham, Alan, ed, Floristics and paleofloristics of Asia and western North America: Amsterdam, Elsevier, p. 201-233.

1977, Paleogene floras from the Gulf of Alaska region: U.S. Geological Survey Professional Paper 997, 108 p.

1978, Paleobotanical interpretations of the Tertiary climates of the northern hemisphere: American Scientist, v. 66, no. 6, p. 694-703.

Wolfe, J.A., Hopkins, D.M., and Leopold, E.B., 1966, Tertisry stratigraphy and paleobotany of the Cook Inlet region, Alaska: U.S. Geological Survey Professional Paper 398-A, 29 p.

Wolfe, J.A., Hopkins, D.M., Leopold, E.B., and Tanat, Toshimasa, 1980, The Miocene Seldovia Point flora from the Kenal Group, Alaska: U.S. Geological Survey Professional Paper 1105, 52 p.

Wyoming Department of Environmental Quality, 1980, Soil and overburden guxdeline: Cheyenne, State of Wyoming Division of Land Quality Guldeline $1,15 \mathrm{p}$.

Zietz, Isidore, Andreasen, G.E., and Grantz, Arthur, 1957, Aeromagnet1c reconnatsance of the Cook Inlet area, Alaska [abs.]: Geological Soctety of Amer1ca Bulletin, v. 68, no. 12, pt. 2, p. 1910.

Zuffa, G.G., N1lsen, T.H., and Vinkler, G.R., 1980, Rock-fragment petrography of the Upper Cretaceous Chugach terrane, southern Alaska: U.S. Geological Survey Open-file Report 80-713, $31 \mathrm{p}$. 
APPENDIX A

General Description of Coal Dutcrops 
Table AI. Coal locales.

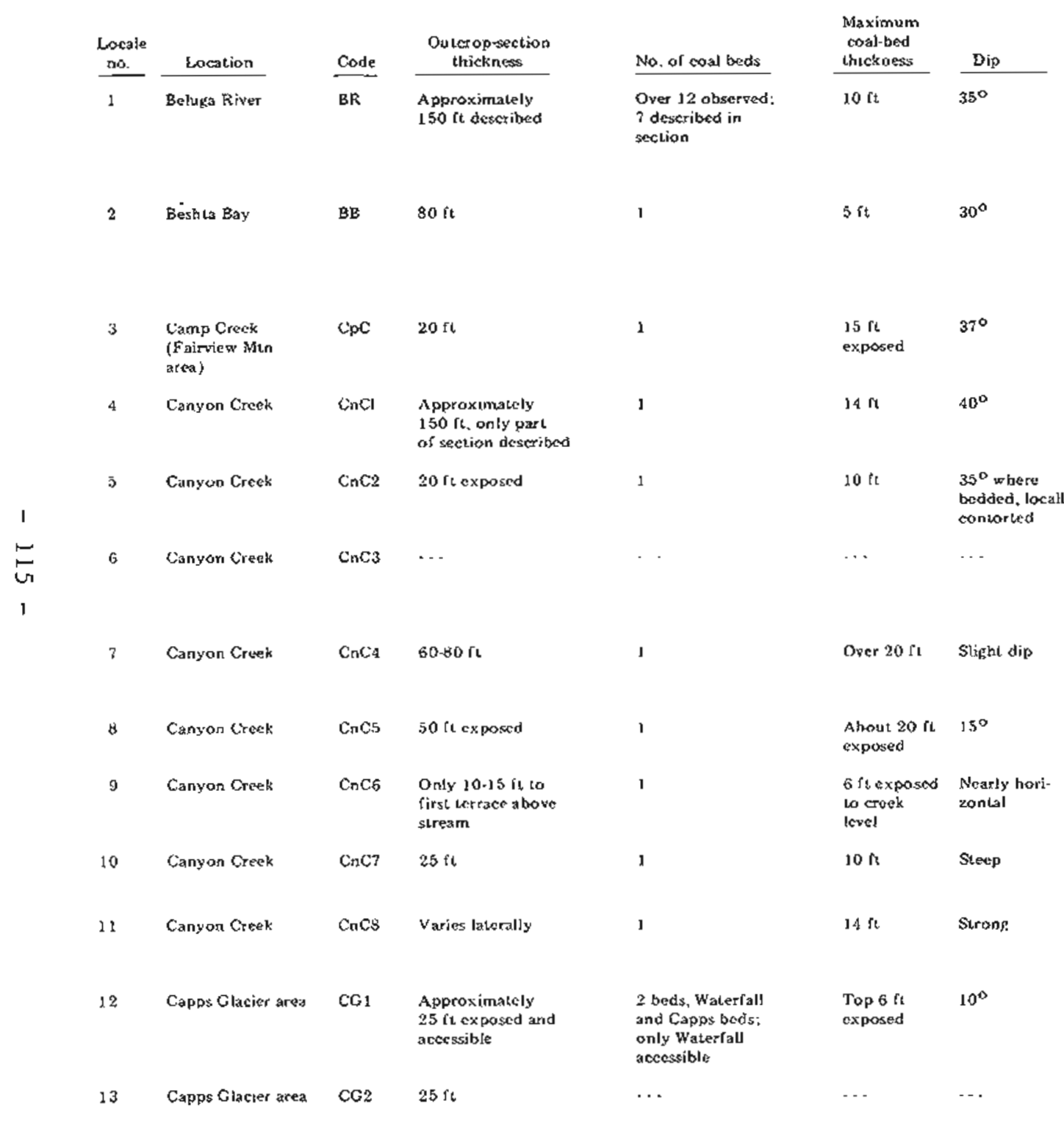

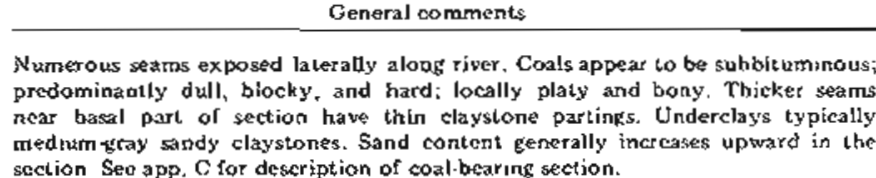

Dull, blocky coal with occasional thin vitrain bands; seam exposed along wast in $10 \mathrm{mi}$ leng bearberop of Beluga Formation. Owcrburden and seatrock const. predominantly of pebsle sandstone and conglomerale, sandstone. light browin. medium graned, locally elayey. Top of section contains wery large boulders y

Predominantly dull, platy coal, becomine blocky toward basal portion; locally, bony. Highly weathered on surses outerop. Exposed for about $200 \mathrm{ft}$ alons

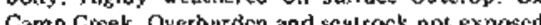

Predominanuly dull, blocky coal, but with abundsnt thin vitran bands. Jsolated

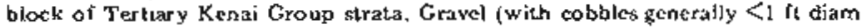
covers operberden section.

Ther maslly alteredi? bed locally severely sontorted becalbec of structural deformat tion, Rim of bighly oxudized fronstone (hematice) torms aureole bectuse of ctlects of natural burning of coal bed

Cradatiunal zanes of burn that include lught-gray baked claystune with ilbundarn

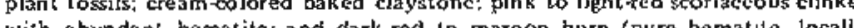

Sile zbout 50 yd south of harke burn area at CnC3, Coal localiy appears thermally 4thed (brbht, vitreous, with conchoidat fracture) Lajge talus slope

Locale is just snuth or Cncl Good expasure at seatrock. Sec $3 \mathrm{pp}$. C for deserip tion of coal-bcaring section.

Seam extends below stram. Locally, stighthly slumped. Roor and floor rot oxposed.

Surface-weathering pattern on cosl very distinctive. Possible volcanic-ashy part ing (tonstein). See app. C for deceription of coal-bearing section.

Compleve seam lhieltness exposed with claystane owcrburden and seatrock Qual. ity of seam delertorates noticeably in basal $2.3 \mathrm{ft}$. See app. C for description of coal be aring section.

Capps and Wakerfali bedis exposed aeross valicy, Area howily wegelated and

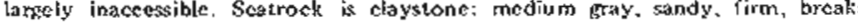
in conchoidal blocks, with local yellow to orange goeth ilic shaiting.

Scction underlyng Capps bed includes iron-oxide stained, conrsegrained sond stonc whth interlayered hemalite bonds and medium-gray, medium-grainsed thard 
Tabie Al. Cocl locales (cont.)

\begin{tabular}{|c|c|c|c|c|c|c|}
\hline $\begin{array}{l}\text { Locale } \\
\text { po. }\end{array}$ & Locatiou & Code & $\begin{array}{l}\text { Outcrop-stetion } \\
\text { thickstess }\end{array}$ & No. of coal beds & $\begin{array}{l}\text { Maximum } \\
\text { coallbed } \\
\text { thickness }\end{array}$ & $D_{1 p}$ \\
\hline 14 & Capps Glacier area & $\cos 3$ & $30 \mathrm{ft}$ & 1. Capps bed & $\begin{array}{l}\text { Top } 6 \mathrm{ft} \\
\text { exposed }\end{array}$ & $3^{\circ}$ \\
\hline 15 & Capps Glacier ares & $\operatorname{cg} 4$ & $50 \mathrm{ft}$ & 1 & $\begin{array}{l}\text { Alout } 20 \mathrm{It} \\
\text { exposed }\end{array}$ & Slight \\
\hline 15 & Capps Glacier area & $\cos 5$ & $130 \mathrm{ft}$ & $\begin{array}{l}\text { 2. Capps and } \\
\text { Water[a]l beds }\end{array}$ & About $30 \mathrm{ht}$ & Slight \\
\hline 17 & Chuitna River & $\mathrm{CR} \mathrm{I}$ & 30 fl exposed & $\cdots$ & $\cdots$ & $\cdots$ \\
\hline 18 & Chultna ftiver & $\mathrm{CR} 2$ & 20 rl exposed & 1 & $\begin{array}{l}10 \mathrm{ftex} \\
\text { posed }\end{array}$ & $30^{\circ}$ \\
\hline 19 & Chuitna River & $\operatorname{Cr} 3$ & $20 f 6$ & 1 & $\begin{array}{l}\text { About } 6 \text { it } \\
\text { exposed }\end{array}$ & $30^{\circ}$ \\
\hline 20 & Chuitna Riwer & $\mathrm{CR} 4$ & 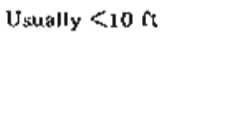 & 1 & $\begin{array}{l}\text { Varies } \\
\text { generally } \\
4-6 \text { lit ex- } \\
\text { posed }\end{array}$ & $30^{\circ}$ \\
\hline 21 & Chuilna River & $\mathrm{CR}_{5}$ & $20 \mathrm{rt}$ & 2 & $8 \mathrm{ft}$ & $4^{\circ}$ \\
\hline 22 & Chuitha River & $\mathrm{Cr} 6$ & $\begin{array}{l}\text { Up lo } 80 \text { it exposed, } \\
\text { but largety in acces- } \\
\text { sible }\end{array}$ & 1 & $>20 \mathrm{ft}$ & $\begin{array}{l}\text { Nearly hori- } \\
\text { tontal }\end{array}$ \\
\hline 23 & Churtna Riwer & CR7 & -. & $\cdots$ & $\cdots$ & $\cdots$ \\
\hline 24 & Chuitna River & $\mathrm{Cr} s$ & $60 \mathrm{rL}$ & 1 & $10 \mathrm{it}$ & $5^{\circ}$ \\
\hline 25 & Chutura Fiver & ORg & sort & 1 & $30 \mathrm{ft}$ & $5^{\circ}$ \\
\hline 26 & Chuiens fliver & CRIO & $90 \mathrm{fL}$ & 1 & Gi $I_{1}$ & $15^{\circ}$ \\
\hline 27 & Coal Crenk & $\mathrm{CCl}_{1}$ & $200 \mathrm{r}$ & $\cdots$ & $\cdots$ & $\cdots$ \\
\hline
\end{tabular}

General comiments Overburden slrata includes predominantly mediucr to dark gray carbonaceous
elaystone and dark gray to black fissle, carbonaceous shales. One thin bed of calcareous sandstone (possibly siderile) with plant-leal Josils. Seatrock mateces bis. See app. $C$ for description of coalbearing se etion.

Good lateral exposure or Cxpps seam along hesaland tylbulary of Capps Creek. One prominent wolcanic-ash parting and teper al otber minor partings occur with in the cosl seam. Locally burned see apo C lor description or the coal-bearine seclion.

boserved from acros the valley on the soutb wall of Capps Creek eanyon alen inaccessible ellefr. fill thickness of coal beds exposed.

White-veathering petbly sandstonc beneath the Chuilna bed; coarse grained loeally slightly elayey; coal forms dn ant ielinal rim around top of out crop.

Back of anticline, unpesure of Chufitma coal bed.

Exposure of Chuntra bed thong stream drainstite; one limb of antucline forms boltom of itream bed. Ste ipp. C ror description of coalbearing section.

Coal at this locale is on the noritheast-trending antictine deseribed at CR2 and

Two seams separated by a 1.5-fi parting of elaystone. Coal extremely weathered

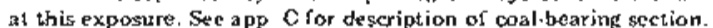

Oulcrop of seatrock of Chuitna bed; westhered, friable sandstone and lowss sand, elatively clcam. fine to medium-menined, predominancly" augere, but with do serrisated black organic matter and axtremely finc muscovile thikes

Outerop of baked enthislone and shale with Imprints of leat fossts, Burn material-seoria. porcellanite, clinker, "red dog. 'Difterent stapes of pxiration and varieties of vesicular hema the; local admixl ures of pyrolusitc ( $\mathrm{MnO}_{2}$ ).

Distinelive differential westhering surfaces (anastamoses) on sandstone roof be burnet. Described from scros riven.

Good exposure of Chuilin bed along southwest wall of promontory, Fosibile volcanic ash parting within coal seam. See app. C for description of coal-bearing section

Exposure includes large area of scoria and baked shale above the coal bed on the south walley wall of the Chuitna kiver. Monweline on suestward exlension (pos-

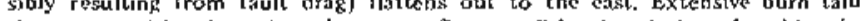
slopes toward basal portion of oulcrop, See app. C for descriplion of coaltbesting

Thick section of Kenal Group strats exposed without coul beds, preduminanly

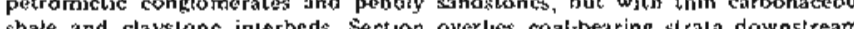




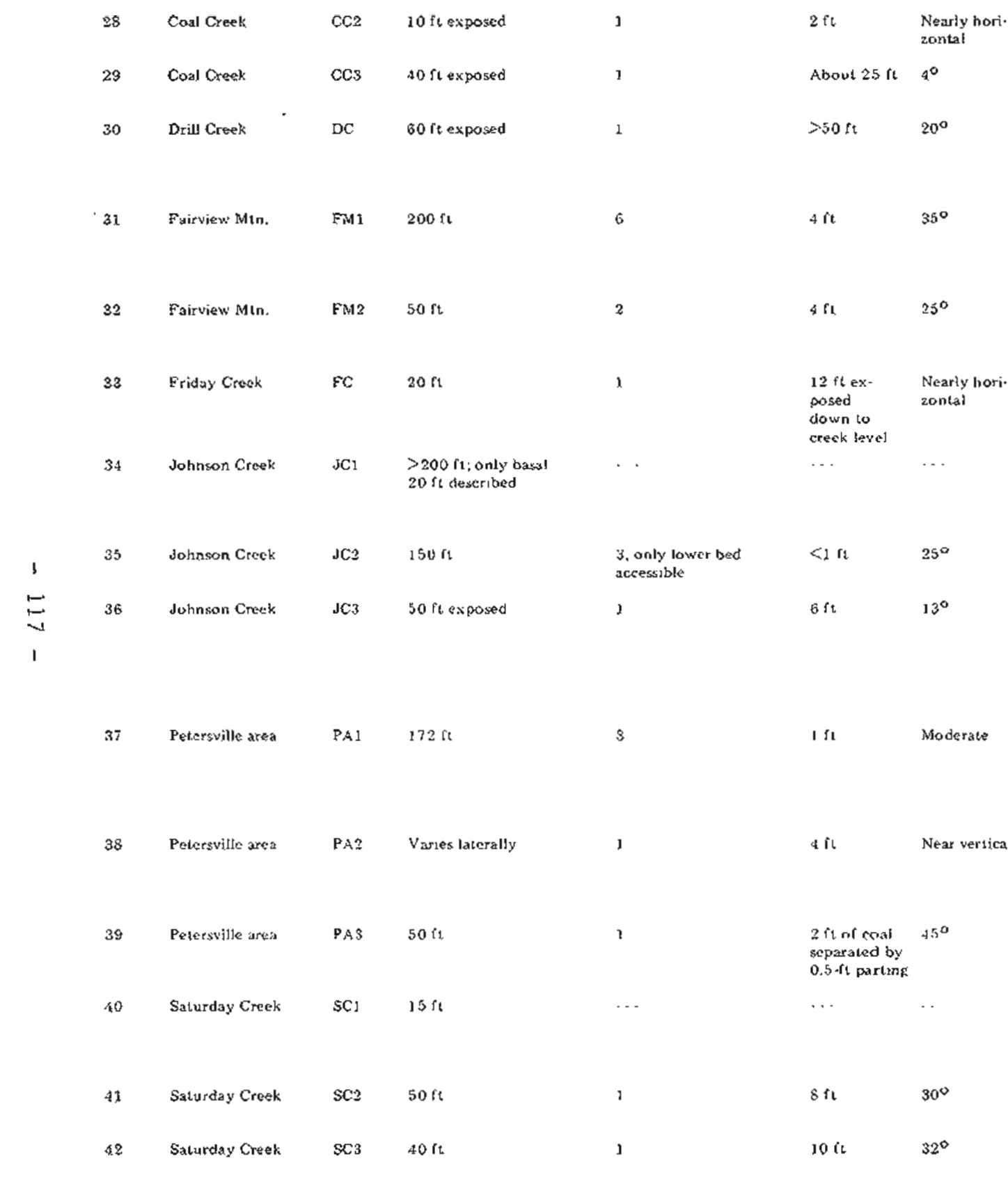

Thit coal seam with roof and floor exposed. Described from across strearn. Cood exposure of cosit seam and seatroek, but roor is covered, Outcrop largedy inaccessible.

Coal platy to slightly blocky, firm to hard with interbands of witainn. Coal expesed in shallow' syndinal basin on southern bank of Drill Creek Aarnes (1966) reporled that this bed was exposed in a samplime trench excavaled by the U.S. Bureau of thines ir: 1960 .

Searss A.F. The two lowest coal beds (scams $A$ and B) are poorly exposed and highily weathered. The coal beds could thicken ennsiderably downdip. Owerburden section consists predominantly of petromictie conglomerates with coal and graphite cobbles and gravels. Sec app. C ror desciption of col-bearmg sectuon.

Represents two lowest beds exposed at FM1 (seams $A$ and B). The coal beds were exposed only by extensive digging at an oucerop on the nor thwest slope of Fairview Mountzin scenap. Clor deccription of coalbeating section

Coal is thard, platy, astby, locedily vilratn-banded, but predominan ely duli, Root and floor unesposed. Lower section of exposure is composed of darkegray praphitic claystone and and an giuamarine weathering rim forms the boundary between the graphitc and quart $x$.

Coal appears themally athered. vitreous, with conchoidal fracture. Carbonacenus shale forms roof and foor. See app. C tor destription of coal-bearing section.

Crops out in south wall of creek Fredominantly a dunt, platy coal with [ew inter banded bright coal layers. Located at base of quartz-pebble conglomerste a the peblaiy sandscone sequence. Coal bed has thin earbonaceous claystone parting toward base. Ironstctie nodules oecur locally in the roof and floor truterial.

Outcrop located on west wall of Short Cecelk, a southwatdflowing tributary of Cache Conek Rapid vertical and tateral shantes in lithologic facies Coals aro thish. hard. dull, andi bluck y. Owerburden indudes a clayslone with distinctive coalified rootlets near the bap of the slratibraphic sequence. See app. $C$ for deseription of coal-bearing section.

Possible volcanue-ash partung in center of coal seam. Coal is woody. A dark gray earbonaceous, feidspathe graywacke stands in relief a heut 15 it a bowe coal bed. bearing section.

Outerop located on Pelers Creef: near Lampoon Pond. Pebaly, conusc-grained sandseane roof and floor exposed.

Banded claystone tait beneath coal exposed at SC2. Unit containd larte oval cotcrehons ( ( have abundant coal banding and car bon aceous root, branch. and lear impressians: other's have iron -rich (hematite) cores,

Possib) flow-roll (ball and pillow) struetures exhibiled in prominent ledge about 6 it below botlom of coal seam. See app. $C$ for description of coal-hearing section.

Channel cutour (exposed in cross section) at west side of outerop; channel filled with sandstone and conglomerale See $\mathrm{app} C$ for description of coulbearing section, 
Table A1. Coal locales (cont.)

\begin{tabular}{|c|c|c|c|c|c|c|c|}
\hline $\begin{array}{l}\text { Locale } \\
\text { no. }\end{array}$ & Location & Conde & $\begin{array}{l}\text { Outcop-section: } \\
\text { thick ness }\end{array}$ & No. of coal beds & $\begin{array}{l}\text { Masiraumb } \\
\text { coal-bed } \\
\text { Lhickness }\end{array}$ & Dip & General comments \\
\hline 43 & Saturday Creek & $\mathrm{Sc} 4$ & $90 \mathrm{rt}$ & 4 & $\begin{array}{l}3 r t: \text { lop } \\
2 \text { beds } \\
\text { separated } \\
\text { by } 2-f \mathrm{f} \\
\text { parting }\end{array}$ & $25^{\circ}$ & 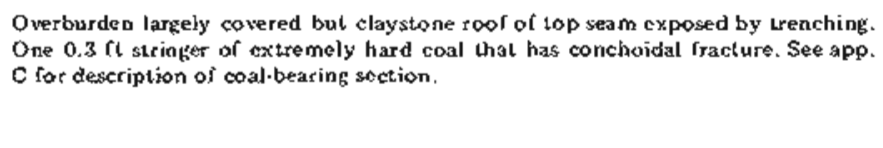 \\
\hline 44 & Skwentna River & sk & $60 \mathrm{ft}$ exposed & $\begin{array}{l}\text { 2. only upper seam } \\
\text { accessible }\end{array}$ & $\begin{array}{l}\text { Upper seant } \\
2 \text { [t; lower } \\
\text { seam approx. } \\
\text { B ft exposed }\end{array}$ & $6^{\circ}$ & 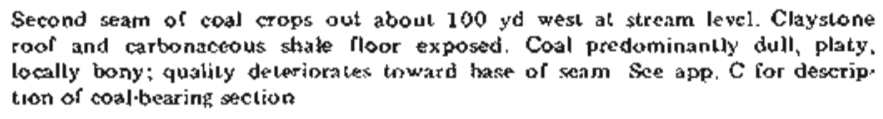 \\
\hline$\{5$ & Sunflower Crepelk & Suc & $70 \mathrm{ft}$ & $x$ & $>50 \mathrm{rt}$ & $\begin{array}{l}\text { Top } 25^{\circ} \text {, baxal } \\
\text { part of besd } \\
\text { approx. } 50^{\circ}\end{array}$ & 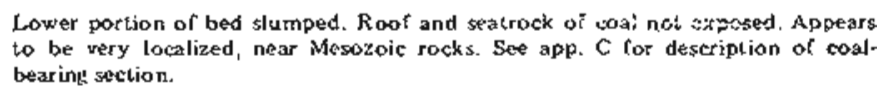 \\
\hline 46 & Talachuliens River & TR & $100 \mathrm{at}$ & 2 & $3 \sqrt{t}$ & $18^{\circ}$ & 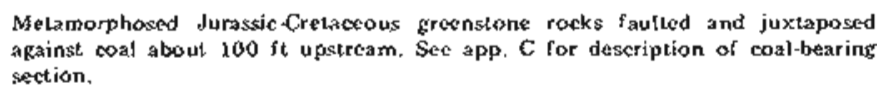 \\
\hline 47 & Wolverine Creek & wCl & Varies taterally & 2 & $7 \mathrm{ft}$ & Nearly vertical & $\begin{array}{l}\text { Located at northern exilremily of Mound Susiloa. Two seams exposed, but section } \\
\text { probably repeated Claystone roof and loor well exposed. }\end{array}$ \\
\hline 48 & Wolverin Crow & $\mathrm{WC2}$ & Variss laterally & 2 & $2 r$ & Sleep & $\begin{array}{l}\text { Clayslome roof of upper seam contains distinctive iton-rich themative core; limo- } \\
\text { nile rimb seghtarian nodules up to } 2 \text { int dizm. See app. C for description of coal- } \\
\text { bearing secuon. }\end{array}$ \\
\hline
\end{tabular}


Table A2. Sample inventory.

\begin{tabular}{|c|c|c|c|c|c|}
\hline $\begin{array}{l}\text { Locale } \\
\text { no. }\end{array}$ & Name & $\begin{array}{l}\text { Site } \\
\text { code }\end{array}$ & Coal & $\begin{array}{c}\text { Samples } \\
\text { Oper burden, } \\
\text { inter burden } \\
\text { (partiags), and } \\
\text { seatrock }\end{array}$ & Petrographic \\
\hline 1 & Beluga River & BR1 & 5 & 11 & 0 \\
\hline 2 & Beshta Bay & BBi & BS1-1 (charnei) & 0 & BB1-1P \\
\hline 3 & Camp Creek & $\mathrm{CpC}_{\mathrm{p} 1}$ & CpCl-1 (channel) & 0 & $\begin{array}{l}\text { CpC1-2 thru } \\
\text { CpC1-7 }\end{array}$ \\
\hline 4 & Eanyon Creek & $\mathrm{CnCl}$ & $\mathrm{CuCl}-1$ (channel) & 0 & $\begin{array}{l}\mathrm{CaCl-2} \text { thru } \\
\mathrm{CnCl}-7\end{array}$ \\
\hline 5 & " & $\mathrm{CnC2}$ & CoC2-1 (channel) & 0 & $\begin{array}{l}\mathrm{CnC} 2-2 \text { thru } \\
\mathrm{CnC} 2-6\end{array}$ \\
\hline 6 & $"$ & $\mathrm{CnC3}$ & 0 & $\begin{array}{l}\mathrm{CnC} 3-1 \text { thru } \\
\mathrm{CnC} 3-5\end{array}$ & 0 \\
\hline 7 & $"$ & $\mathrm{CnC} 4$ & CoC4-1 (channel) & 0 & $\begin{array}{l}\mathrm{CaC} 4-2 \text { thru } \\
\mathrm{CaC} 4-11\end{array}$ \\
\hline 8 & $"$ & $\mathrm{CnC5}$ & 0 & 4 & 0 \\
\hline 9 & $"$ & $\mathrm{CnC6}$ & CnC6-I (channel) & 0 & $\begin{array}{l}\text { CnC6-2 thru } \\
\text { СnC6-6 }\end{array}$ \\
\hline 10 & " & $\mathrm{CnC7}$ & 1 (channe) & 0 & 9 \\
\hline 11 & " & $\mathrm{CnCs}$ & $I$ (channel) & 3 & 0 \\
\hline 12 & Capps Glacier area & CG 1 & CG1-1 (channel) & CG1-1 und & $\mathrm{CO} 1-1 \mathrm{p}$ \\
\hline 13 & " & CG2 & 0 & 0 & 0 \\
\hline 14 & $"$ & CG3 & 1 (channel) & 9 & 3 \\
\hline 15 & $"$ & $\mathrm{CG} 4$ & $\begin{array}{l}5 \text { (channels of } \\
\text { seam and por- } \\
\text { tions of) }\end{array}$ & 2 & 10 \\
\hline 16 & " & $\mathrm{CG} 5$ & 0 & 0 & 0 \\
\hline 17 & Chuitna River & $\mathrm{CRI}$ & 0 & CRl-1 & 0 \\
\hline 18 & $"$ & $\mathrm{CR} 2$ & 0 & 0 & 0 \\
\hline 19 & $"$ & $\mathrm{CR} 3$ & 1 (channel) & 2 & 1 \\
\hline 20 & $"$ & $\mathrm{CR} 4$ & 0 & 0 & 0 \\
\hline 21 & $"$ & CR5 & $\begin{array}{l}2 \text { (channels of } \\
\text { portions of seam) }\end{array}$ & 1 & 2 \\
\hline 22 & "' & CR6 & CR6-1 (cbannel) & 0 & 0 \\
\hline 23 & $"$ & $\mathrm{CR} 7$ & 0 & CR $7 \cdot 2$ & 0 \\
\hline 24 & ". & CR8 & 0 & 0 & 0 \\
\hline 25 & " & CR9 & $\begin{array}{l}2 \text { (channels of } \\
\text { portions of seam) }\end{array}$ & 2 & 7 \\
\hline 26 & $"$ & CR10 & 1 (channel) & 1 & 5 \\
\hline
\end{tabular}

\section{Comments}

See app. C for sample locations

Giab sample for petrography taken near center of outcropping seam.

Petrographic samples taken at intervals within searo.

Samples of gradational zones of burn material.

Petrographic samples taken at intervals within seam.

See app. C for sample locations.

Petrographic samples taken at intervals within seam.

See app. C for sample locations.

Petrographic sample taken near middle of outcropping portion of seam.

No samples collected.

See app. C for sample locations.

No samples collected.

Sample of white-weathering pebbly sandstone.

No samples collected.

See app. $\mathrm{C}$ for sample locations.

No samples collected.

See app. C for sample locations

Baked sandstone

No samples collected.

See app. C for sample locations.

See app. C for sample locations. 
Table A2. Sample inventory (cont.)

\begin{tabular}{|c|c|c|c|c|c|c|}
\hline $\begin{array}{l}\text { Locale } \\
\text { no. }\end{array}$ & Name & $\begin{array}{l}\text { Site } \\
\text { code }\end{array}$ & Coal & $\begin{array}{c}\text { Samples } \\
\text { Overburden, } \\
\text { interburden } \\
\text { (partings), and } \\
\text { seatrock }\end{array}$ & Petrographic & Comments \\
\hline 27 & Coal Creek & $\mathrm{COI}$ & 0 & 0 & 0 & No samples collected. \\
\hline 28 & " & $\mathrm{CC} 2$ & 0 & 0 & 0 & \\
\hline 29 & $"$ & $\mathrm{CC} 3$ & $\begin{array}{l}\text { CC3-1 thru CC3-4 } \\
\text { (channeis of seamm }\end{array}$ & CC3 unel & $\begin{array}{l}\text { CC3-1p thru } \\
\text { CC3-4p }\end{array}$ & $\begin{array}{l}\text { Petrographic samples taken near center of channeled } \\
\text { sections of outcropping seam. }\end{array}$ \\
\hline 30 & Drill Creek & $\mathrm{DCl}$ & $\begin{array}{l}\text { DC1-1, } \\
\text { DC1-2 } \\
\text { (channels top and } \\
\text { bottom half of } \\
\text { outcropping seam) }\end{array}$ & 0 & $\begin{array}{l}\text { DC1-1p } \\
\text { DC1-2p }\end{array}$ & $\begin{array}{l}\text { Pekrographic samples collected near center of } \\
\text { channeled sections. }\end{array}$ \\
\hline 31 & Fairview Mountain & FM1 & 5 & 10 & 9 & See app. $C$ for sample tocations. \\
\hline 32 & $"$ & FM2 & 3 & 4 & 4 & $-x=0$ \\
\hline 33 & Friday Creek & $\mathrm{FrCl}$ & FrCl-1 (channel) & 0 & 0 & $\cdots$ \\
\hline 34 & Johnson Creek & $\mathrm{JC1}$ & 0 & $\begin{array}{l}\text { JC1-1 } \\
\text { JC1-2 } \\
\text { JC1-3 }\end{array}$ & 0 & $\cdots$ \\
\hline 35 & $"$ & $\mathrm{JC2} 2$ & 1 (channel) & 3 & 1 & See app. $C$ for sample locations. \\
\hline 36 & " & $\mathrm{JC} 3$ & 2 (channels) & 4 & 0 & $"$ \\
\hline 37 & Petersville area & PA1 & 3 (channels) & 35 & 2 & $"$ \\
\hline 38 & " & PA2 & 1 (chanoel) & 2 & 1 & " \\
\hline 39 & " & PA3 & 2 (channels) & 1 & 2 & $"$ \\
\hline 40 & Saturday Creek & $\mathrm{SCl}$ & 0 & $\begin{array}{l}\text { SC1-1 } \\
\text { SC1-2 }\end{array}$ & 0 & $\mathrm{cos}^{\circ} \mathrm{sec}$ \\
\hline 41 & " & $\mathrm{sc2}$ & 2 & 1 & 2 & See app. $\mathrm{C}$ for sample locations. \\
\hline 42 & $"$ & $\mathrm{SC3}$ & 1 & 3 & 1 & " \\
\hline 43 & " & $\mathrm{SC4}$ & 4 & 9 & 6 & $"$ \\
\hline 44 & Skwentna River & SR 1 & 1 & 8 & 2 & $"=$ \\
\hline 45 & Sunflower Creek & $\mathrm{SuCl}$ & 0 & 0 & 0 & No sampies collected. \\
\hline 46 & Talachulitna River & TE I & $I$ & 2 & 1 & See app. $C$ for sample locations. \\
\hline 47 & Wolverine Creek & $\mathrm{WC1}$ & 2 & 4 & 2 & " \\
\hline 48 & & WO2 & 4 & 11 & 3 & $"$ \\
\hline
\end{tabular}


Table A.3. Specific location information for Susina lowland coal and overburden sampling sites.

\begin{tabular}{|c|c|c|c|c|c|c|c|}
\hline $\begin{array}{l}\text { Site } \\
\text { cole }\end{array}$ & $\begin{array}{l}\text { Coal-resource } \\
\text { region }\end{array}$ & Quadrangle & Torviship & Range & Section & Latilude & Longitude \\
\hline BRI & Southcentiral & Tyonek A-4 & $13: V$ & $11 \mathrm{~W}$. & 14 & $61^{\circ} 12^{\prime} 46^{\prime \prime}$ & $151^{\circ} 11^{\prime} 3^{\prime \prime}$ \\
\hline $\mathrm{BB} 1$ & Southcentral & Tyonek A-4 & $11 \mathrm{~N}$ & $11 \mathrm{~W}$. & 19 & $61^{\circ} 1^{\prime} 54^{\prime \prime}$ & $151^{\circ} 18^{\prime} 27^{\prime \prime}$ \\
\hline $\mathrm{CpCl}$ & Southcentral & Talkeetns B-3 & $27 \mathrm{~N}$. & $12 \mathrm{~W}$. & 27 & $62^{\circ} 23^{\prime} 43^{\prime \prime}$ & $151^{\circ} 28^{\prime} 46^{\prime \prime}$ \\
\hline $\mathrm{CnCl}$ & Southcentral & Tyonek D.5 & $19 \mathrm{~N}$ & $13 \mathrm{~W}$ & 6 & $61^{\circ} 45 \cdot 56^{\prime \prime}$ & $151^{\circ} 41^{\prime} 13^{\prime \prime}$ \\
\hline $\mathrm{CnC2}$ & Southcentral & Tyonek D-5 & $19 \mathrm{~N}$ & $13 \mathrm{~W}$. & 7 & $61^{\circ} 45^{\prime} 27^{\prime \prime}$ & $151^{\circ} 42^{\prime} 14^{\prime \prime}$ \\
\hline $\mathrm{CnC} 3$ & Southcentral & Tyonek D.5 & $19 \mathrm{~N}$ & $13 \mathrm{w}$. & 7 & $61^{\circ} 45^{\prime} 24^{\prime \prime}$ & $151^{\circ} 42^{\prime} 14^{\prime \prime}$ \\
\hline $\mathrm{CnC}_{4}$ & Southcentral & Tyonek D.5 & $19 \mathrm{~N}$. & $13 \mathrm{w}$ & 7 & $61^{\circ} 45^{\prime} 21^{\prime \prime}$ & $151^{\circ} 42^{\prime} 9^{\prime \prime}$ \\
\hline $\mathrm{CnC5}$ & Southcentral & Tyonek D.5 & $19 \mathrm{~N}$. & $13 \mathrm{w}$ & 6 & $61^{\circ} 45.52^{\prime \prime}$ & $151^{\circ} 41^{\prime} 13^{\prime \prime}$ \\
\hline $\mathrm{CnC6}$ & Soutlicentral & Tyonek D.5 & $20 \mathrm{~N}$ & $14 \mathrm{~W}$. & 35 & $61^{\circ} 46^{\prime} 42^{\prime \prime}$ & $151^{\circ} 45^{\prime} 26^{\prime \prime}$ \\
\hline $\mathrm{CnC7}$ & Southcentral & Tyonek D-5 & $20 \mathrm{~N}$. & $13 \mathrm{~W}$. & 19 & $61^{\circ} 48^{\prime} 10^{\prime \prime}$ & $151^{\circ} 42^{\prime} 36^{\prime \prime}$ \\
\hline $\mathrm{CnC} 8$ & Southcentral & Tyonek D-5 & $20 \mathrm{~N}$. & $13 \mathrm{~W}$. & 19 & $61^{\circ} 48.5 "$ & $151^{\circ} 41^{\prime} 36^{\prime \prime}$ \\
\hline $\mathrm{CGl}$ & Soutlicentral & Tyonek B-5 & $14 \mathrm{~N}$. & $14 \mathrm{~W}$ & 16 & $61^{\circ} 18^{\prime} 7^{\prime \prime}$ & $151^{\circ} 45^{\prime} 30^{\prime \prime}$ \\
\hline $\mathrm{CG} 2$ & Southcentral & Tyonek B-5 & $14 \mathrm{~N}$ & $14 \mathrm{~W}$. & 23 & $61^{\circ} 17^{\prime} 21^{\prime \prime}$ & $151^{\circ} 43^{\prime} 18^{\prime \prime}$ \\
\hline $\mathrm{CG} 3$ & Southcentral & Tyonek B.5 & $14 N$ & $14 \mathrm{~W}$ & 13 & $61^{0} 17^{\circ} 57^{\prime \prime}$ & $151^{\circ} 43^{\prime} 3^{\prime \prime}$ \\
\hline CG4 & Southcentral & Tyonek B.5 & $14 N$ & $14 \mathrm{~W}$. & 27 & $61^{\circ} 16^{\prime} 50^{\prime \prime}$ & $151^{\circ} 46^{\prime} 15^{\prime \prime}$ \\
\hline $\mathrm{Ca} 5$ & South central & Tyonek B.5 & $14 N$ & $14 \mathrm{~W}$. & 24 & $61^{\circ} 17^{\prime} 13^{\prime \prime}$ & $151^{\circ} 42^{\prime} 42^{\prime \prime}$ \\
\hline CR1 & Southcencral & Tyonek A.5 & $13 \mathrm{~N}$. & $13 \mathrm{~W}$. & 29 & $\left.61^{\circ}\right] 11^{\prime \prime}$ & $151^{\circ} 38^{\prime} 00^{\prime \prime}$ \\
\hline $\mathrm{CR} 2$ & Soullicentral & Tyonek A.5 & $13 N$. & $13 \mathrm{~W}$. & 29 & $81^{\circ} 10^{\prime} 58^{\prime \prime}$ & $151^{\circ} 37^{\prime 64}$ \\
\hline CR3 & Southcentral & Tyonek A.5 & $13 \mathrm{~N}$ & $13 \mathrm{~W}$. & 28 & $61^{\circ} 11$ '4"' & $151^{\circ} 37^{\prime} 38^{\prime \prime}$ \\
\hline CR4 & Soulhcential & Tyonek A.6 & $13 \mathrm{~N}$. & $13 \mathrm{w}$. & 28 & $61^{\circ} 11 \cdot 13^{\prime \prime}$ & $151^{\circ} 37^{\prime} 37^{\prime \prime}$ \\
\hline CR5 & Soulhcentral & Tyonek A.4 & $12 \mathrm{~N}$. & $12 \%$ & 24 & $61^{\circ} 7^{\prime} 13^{\prime \prime}$ & $151^{\circ} 18^{\prime} 66^{\prime \prime}$ \\
\hline CR6 & Soulincential & Tyonek A-4 & $12 \mathrm{~N}$. & $12 \mathrm{~W}$. & 6 & $61^{\circ} 9^{\prime} 16^{\prime \prime}$ & $151^{\circ} 29^{\prime} 14^{\prime \prime}$ \\
\hline CR7 & Southcentral & Tyonek A.5 & $13 \mathrm{~N}$ & $13 \mathrm{w}$. & 35 & $61^{\circ} 0_{10} 3^{\prime \prime}$ & $151^{\circ} 32^{\prime} 30^{\prime \prime}$ \\
\hline CR8 & Southcentral & Tyonek A-5 & $12 N$ & $13 \mathrm{~W}$ & 1 & $61^{\circ} \mathcal{Q}^{\prime} 11^{\prime \prime}$ & $151^{\circ} 30^{\prime} 8^{\prime \prime}$ \\
\hline CR9 & Southcentra! & Tyonek $\Lambda-5$ & $12 \mathrm{~N}$. & $13 \mathrm{~W}$ & 1 & $61^{0} 9^{\prime} 23^{\prime \prime}$ & $151^{\circ} 30^{\prime} 31^{\prime \prime}$ \\
\hline CR10 & Southcentral & Tyonek A-6 & $13 \mathrm{~N}$. & $13 \mathrm{~W}$ & 27 & $61^{0} 11^{\prime} 18^{\prime \prime}$ & $151^{\circ} 35^{\prime} 32^{\prime \prime}$ \\
\hline $\mathrm{CCl}$ & Soutincentral & I'yonek B-5 & $16 \mathrm{~N}$. & $13 \mathrm{~W}$. & 26 & $61^{\circ} 26^{\prime} 48^{\prime \prime}$ & $151^{\circ} 32^{\prime} 52^{\prime \prime}$ \\
\hline $\mathrm{CC} 2$ & Southcentral & Tyonek B-5 & $1 G N$. & $13 \mathrm{~W}$. & 36 & $B 1^{\circ} 26^{\prime} 13^{\prime \prime}$ & $151^{\circ} 31^{\prime} 30^{\prime \prime}$ \\
\hline $\mathrm{CC} 3$ & Soulincentiral & Tyonek B-5 & $16 \mathrm{~N}$. & $13 \mathrm{~W}$. & 36 & $61^{\circ} 26^{\circ} 10^{\prime \prime}$ & $151^{\circ} 30^{\prime} 38^{\prime \prime}$ \\
\hline DC1 & Southcentral & Tyonek B-4 & $15 \mathrm{~N}$. & $12 \mathrm{~W}$. & 11 & $61^{0} 24^{\prime} 16^{\prime \prime}$ & $151^{\circ} 22^{\prime} 50^{\prime \prime}$ \\
\hline FM1 & Southcentral & Talkectna B-1 & $26 \mathrm{~N}$. & $12 \mathrm{~W}$. & 7 & $62^{\circ} 21^{\prime} 52^{\prime \prime \prime}$ & $151^{\circ} 34^{\prime} 40^{\prime \prime}$ \\
\hline FM2 & Southcentral & Talkcetna $B-4$ & $26 \mathrm{~N}$. & $12 \mathrm{~W}$. & 6 & $62^{\circ} 22^{\prime} 4^{\prime \prime}$ & $151^{\circ} 33^{\prime} 56^{\prime \prime}$ \\
\hline FCI & Southcentral & Tyonek C.5 & $19 \mathrm{~N}$. & $13 w$ & 35 & $61^{\circ} 11^{\prime} 36^{\prime \prime}$ & $151^{\circ} 35^{\prime} 12^{\prime \prime}$ \\
\hline JC1 & Soullicentral & Talkeetra A-5 & $23 N$ & $15 \mathrm{~W}$. & 21 & $62^{\circ} 3^{\prime} 58^{\prime \prime}$ & $152^{\circ} 2^{\prime} 00^{\prime \prime}$ \\
\hline $\mathrm{JC} 2$ & Southcentral & Talkeetna A-4 & $23 N$ & $15 \mathrm{~W}$. & 23 & $62^{\circ} 3^{\prime} 49^{\prime \prime}$ & $151^{\circ} 57^{\prime} 47^{\prime \prime}$ \\
\hline $\mathrm{JC3}$ & Southcencral & Talkeetna A-4 & $23 N$ & $14 \mathrm{~W}$. & 30 & $62^{\circ} 3^{\prime} 21^{\prime \prime}$ & $151^{\circ} 54^{\prime} 18^{\prime \prime}$ \\
\hline PAI & Southcentral & Talkeetna B-3 & $28 \mathrm{~N}$. & $10 \mathrm{~W}$. & 36 & $62^{\circ} 28^{\prime} 28^{\prime \prime}$ & $151^{\circ} 2^{\prime} 6^{\prime \prime}$ \\
\hline PA2 & Southcentral & Talkeetna B.2 & $27 \mathrm{~N}$. & $8 \mathrm{~W}$ & 18 & $62^{\circ} 25^{\prime \prime} 46^{\prime \prime}$ & $150^{\circ} 49^{\prime} 33^{\prime \prime}$ \\
\hline PA3 & Southcentral & Tralkeenna B-2 & $27 \mathrm{~N}$ & $8 \mathrm{~W}$ & 22 & $62^{\circ} 25^{\prime} 00^{\prime \prime}$ & $150^{\circ} 44^{\prime} 21^{\prime \prime}$ \\
\hline $\mathrm{SCl}$ & Southcentral & Tyonek C-5 & $18 \mathrm{~N}$ & $13 w$. & 1 & $61^{\circ} 40^{\prime} 24^{\prime \prime}$ & $151^{\circ} 33^{\prime} 31^{\prime \prime}$ \\
\hline $\mathrm{SC} 2$ & Southcentral & Tyonek C.5 & $18 N$ & $13 \mathrm{w}$ & 2 & $61^{\circ} 40^{\prime} 42^{\prime \prime}$ & $151^{\circ} 34^{\prime} 12^{\prime \prime}$ \\
\hline SC3 & Southcentral & Tyonek C.5 & $18 \mathrm{~N}$ & $13 \mathrm{~W}$. & 2 & $61^{\circ} 40^{\prime} 47^{\prime \prime}$ & $151^{\circ} 34^{\prime} 36^{\prime \prime}$ \\
\hline $\mathrm{SC} 4$ & Southcentral & Tyonek C-5 & $18 \mathrm{~N}$ & $13 \mathrm{~W}$. & 2 & $61^{\circ} 40^{\circ} 53^{\prime \prime}$ & $151^{\circ} 35^{\prime} 3^{\prime \prime}$ \\
\hline SR1 & Southcentral & Tyonek D-6 & $22 \mathrm{~N}$ & $15 \mathrm{~W}$. & 23 & $61^{\circ} 58^{\prime} 42^{\prime \prime}$ & $151^{\circ} 57^{\prime} 27^{\prime \prime}$ \\
\hline $\mathrm{SuC} 1$ & Southcentral & Talkeetna B-3 & $27 \mathrm{~N}$ & $12 \mathrm{~W}$. & 26 & $62^{\circ} 24 ' 17^{\prime \prime}$ & $151^{\circ} 27^{\prime} 3^{\prime \prime}$ \\
\hline TR1 & South central & Tyonek C-4 & $19 \mathrm{~N}$. & $12 \mathrm{~W}$. & 21 & $61^{\circ} 3^{\prime} 6^{\prime \prime}$ & $151^{\circ} \%^{\prime} 8$ ' \\
\hline WC1 & Souticential & Tyonek C-3 & $17 \mathrm{~N}$. & $9 \mathrm{~W}$ & 1 & $61^{\circ} 35^{\prime} 12^{\prime \prime}$ & $150^{\circ} 49^{\prime} 41^{\prime \prime}$ \\
\hline WC2 & Soulincentral & Tyonek C.3 & $17 \mathrm{~N}$. & $9 \mathrm{~W}$. & 24 & $61^{\circ} 33^{\prime} 15^{\prime \prime}$ & $150^{\circ} 50^{\prime} 4^{\prime \prime}$ \\
\hline
\end{tabular}


APPENDTX $B$

Coa1-analysis data 
Table B-1. Concentration of mojor axides in ash of raw cools (\%). From Rao and Wolff, 1981

\begin{tabular}{|c|c|c|c|c|c|c|c|c|c|c|c|c|}
\hline $\begin{array}{c}\text { Coal field, } \\
\text { bed }\end{array}$ & $\begin{array}{c}\text { ASTM } \\
\text { rank }\end{array}$ & $\begin{array}{c}\text { Thickness, } \\
\text { m (ft) }\end{array}$ & Sample & $\mathrm{SiO}_{2}$ & $\mathrm{Al}_{2} \mathrm{O}_{3}$ & $\mathrm{Feg}_{2} \mathrm{O}_{3}{ }^{\mathrm{A}}$ & $\begin{array}{l}\mathrm{Mg}(\%) \\
\mathrm{MgO}\end{array}$ & $\mathrm{CaO}$ & $\mathrm{Na}_{2} \mathrm{O}$ & $\mathrm{K}_{2} \mathrm{O}$ & $\mathrm{TiO}_{2}$ & $\mathrm{MnO}$ \\
\hline $\begin{array}{l}\text { Beluga, } \\
\text { Waterfalk }\end{array}$ & Subbit. C & $\begin{array}{c}9.3 \\
(30)\end{array}$ & $\mathrm{UA}-113$ & 41.0 & 28.9 & 6.7 & 1.9 & 16.6 & 0.18 & 2,2 & 0.8 & 0.10 \\
\hline $\begin{array}{l}\text { Yentna, } \\
\text { Surflower } \\
\text { (upper) }\end{array}$ & Lignite & $\begin{array}{c}3.0 \\
(10)\end{array}$ & UA-115 & 16.8 & 33.3 & 9.5 & 6.3 & 28.0 & 0.26 & 1.0 & 1.1 & 0.12 \\
\hline $\begin{array}{l}\text { Yentna, } \\
\text { Sunflower } \\
\text { (lower) }\end{array}$ & Lignite & $\begin{array}{c}3.0 \\
(10)\end{array}$ & UA-116 & 11.6 & 27.9 & 10.6 & 7.4 & 37.2 & 0.27 & 0.6 & 0.8 & 0.13 \\
\hline
\end{tabular}

Table B-2. Concentration of trace elements in row coal ashes (ppm). From Rao and Wolff. 1981

\begin{tabular}{|c|c|c|c|c|c|c|c|c|c|c|c|c|c|c|}
\hline Sample & $\mathrm{Ag}$ & $\mathrm{B}$ & $\mathrm{Ba}$ & Co & $\mathrm{Cu}^{\mathrm{a}}$ & $\mathrm{Cr}$ & $\mathrm{Ga}$ & Mo & $\mathrm{Ni}^{\mathrm{a}}$ & $\mathrm{Pb}$ & Sn & $\mathrm{V}$ & $\mathrm{Zn}^{\mathrm{a}}$ & $\mathrm{Zr}$ \\
\hline JA-113 & N.D. & 1,30 & 5,200 & 88 & 164 & 230 & 52 & N.D. & 121 & 110 & N.D. & 360 & 182 & 420 \\
\hline UA-1 15 & 1.3 & 320 & 5,700 & 35 & 230 & 160 & 47 & N.D. & 130 & 42 & 48 & 220 & 100 & 480 \\
\hline UA-116 & 1.6 & 370 & 5,500 & 98 & 250 & 170 & 31 & 10 & 165 & 83 & 28 & 240 & 120 & 750 \\
\hline
\end{tabular}

$\overline{a_{\text {A }} \text { amic absorption. }}$ 
Table B.3, Vitrinite-refleclance data as measured from ulminite macerals, selected Susitna lowland coals.

\begin{tabular}{|c|c|c|c|c|c|c|}
\hline \multirow[b]{2}{*}{ Sample } & \multicolumn{5}{|c|}{ Frequency histogram-vitrinite types (\%) } & \multirow{2}{*}{$\begin{array}{c}\text { Mean maximum } \\
\text { reflectance ( } \text { Rom } \% \text { ) }\end{array}$} \\
\hline & V2 & V3 & V4 & V5 & $\sqrt{6}$ & \\
\hline BB $1-1$ & & 26 & 42 & 32 & & 0.45 \\
\hline BR1-1 & 20 & 70 & 4 & 4 & 2 & 0.94 \\
\hline$B R 1 \cdot 4$ & 48 & 42 & 10 & & & 0.31 \\
\hline BR1-8 & & 82 & 38 & & & 0.38 \\
\hline BR1-12 & 46 & 42 & 12 & & & 0.32 \\
\hline BR1-15 & & 74 & 22 & 4 & & 0.38 \\
\hline $\mathrm{CpC1-1}$ & 12 & 68 & 20 & & & 0.35 \\
\hline $\mathrm{CnC1} \cdot 1$ & 2 & 54 & 42 & 2 & & 0.39 \\
\hline $\mathrm{CnC} 2 \cdot 1$ & 18 & 70 & 12 & & & 0.33 \\
\hline $\mathrm{CnC2}-2$ & 16 & 76 & 8 & & & 0.33 \\
\hline $\mathrm{CnC} 2-3$ & & 98 & 2 & & & 0.34 \\
\hline $\mathrm{CnC2}-4$ & 6 & 92 & 2 & & & 0.34 \\
\hline $\mathrm{CnC} 2.5$ & 8 & 92 & & & & 0.32 \\
\hline $\mathrm{CnC} 2-6$ & 2 & 94 & 4 & & & 0.35 \\
\hline $\mathrm{CnC4-1}$ & 44 & 54 & 2 & & & 0.30 \\
\hline $\mathrm{CnC4}-2$ & 34 & 56 & 10 & & & 0.32 \\
\hline $\mathrm{CnC} 4-3$ & 32 & 82 & 6 & & & 0.31 \\
\hline $\mathrm{CnC4}-4$ & 26 & 70 & 4 & & & 0.31 \\
\hline $\mathrm{CnC}_{4-5}$ & 4 & 94 & 2 & & & 0.86 \\
\hline $\mathrm{CnC} 4.6$ & 56 & 42 & 2 & & & 0,30 \\
\hline $\mathrm{CnC} 4-7$ & 82 & 16 & 2 & & & 0.37 \\
\hline $\mathrm{CnC} 4-8$ & 26 & 74 & & & & 0.92 \\
\hline $\mathrm{CnC} 4-9$ & 6 & 72 & 22 & & & 0.37 \\
\hline $\mathrm{CnC4} 10$ & 32 & 88 & & & & 0.33 \\
\hline CnC4-11 & 8 & 88 & 4 & & & 0.84 \\
\hline $\mathrm{CnC} 6-1$ & 12 & 80 & 8 & & & 0.34 \\
\hline $\mathrm{CnC} 7-1$ & 34 & 62 & 2 & 2 & & 0.31 \\
\hline $\mathrm{CnC} 8-2$ & 4 & 88 & 8 & & & 0.91 \\
\hline$C G 1-1$ & & 42 & 52 & 6 & & 0.41 \\
\hline CG3-10 & & 82 & 16 & 2 & & 0.36 \\
\hline CG4-I & & 32 & 52 & 14 & & 0.42 \\
\hline $\mathrm{CG} 4 \cdot 2$ & 8 & 70 & 22 & & & 0.36 \\
\hline CG4.4 & 14 & 48 & 36 & 2 & & 0.37 \\
\hline CG4.5 & 18 & 68 & 12 & 2 & & 0.35 \\
\hline CRS-1 & & 76 & 22 & 2 & & 0.37 \\
\hline CR5-1 & & 58 & 38 & 4 & & 0.39 \\
\hline CR5.3 & 14 & 82 & 4 & & & 0.34 \\
\hline CRG-1 & & 42 & 44 & 12 & 2 & 0.42 \\
\hline CR9-1 & & 60 & 38 & 2 & & 0.38 \\
\hline CRIO-1 & & 64 & 34 & 2 & & 0.39 \\
\hline CC3-1 & 24 & 58 & 16 & 2 & & 0.34 \\
\hline $\mathrm{CC} 3.4$ & & 72 & 28 & & & 0.37 \\
\hline DCl - I & 6 & 48 & 26 & 18 & 2 & 0.41 \\
\hline $\mathrm{DCl} \cdot 2$ & 4 & 88 & 8 & & & 0.35 \\
\hline FM1-2 & & 68 & 26 & 6 & & 0.88 \\
\hline$F M 1-4$ & & 48 & 48 & 4 & & 0.40 \\
\hline FMI-7 & 8 & 56 & 34 & 2 & & 0.37 \\
\hline FM1-10 & 10 & 70 & 18 & 2 & & 0.36 \\
\hline FMI-13 & & 60 & 50 & & & 0.39 \\
\hline FM2-I & 58 & 36 & 6 & & & 0.30 \\
\hline FM2-2 & 12 & 78 & 10 & & & 0.34 \\
\hline FM2.6 & 30 & 54 & 16 & & & 0.33 \\
\hline FM2-8 & 100 & & & & & 0.23 \\
\hline FrCl-1 & 4 & 64 & 28 & & 4 & 0.38 \\
\hline $\mathrm{JC3}-1$ & 2 & 76 & 20 & 2 & & 0.37 \\
\hline $\mathrm{JC3}-5$ & 12 & 66 & 18 & 4 & & 0.37 \\
\hline
\end{tabular}


Table B-9. Vitrinite-reflectance dala, selected Susilnc I owland coals (cont.)

\begin{tabular}{|c|c|c|c|c|c|c|}
\hline \multirow[b]{2}{*}{ Sample } & \multicolumn{5}{|c|}{ Frequency histogram-vitrinite types (\%) } & \multirow{2}{*}{$\begin{array}{c}\text { Mean maximum } \\
\text { reflectance ( } \bar{R} \text { Rom\%) }\end{array}$} \\
\hline & $\underline{\mathrm{V} 2}$ & V3 & V4 & $\underline{V 5}$ & V6 & \\
\hline PA1-5 & 24 & 68 & 8 & & & 0.98 \\
\hline PA1-82 & & 86 & 14 & & & 0.36 \\
\hline PA1-34 & 42 & 68 & & & & 0.31 \\
\hline PA2-1 & 22 & 64 & 14 & & & 0.34 \\
\hline PA3-1 & & 54 & 44 & 2 & & 0.40 \\
\hline $5 C 2-3$ & 2 & 62 & 36 & & & 0.38 \\
\hline $\mathrm{SCB} \cdot 1$ & & 72 & 22 & 6 & & 0.38 \\
\hline SC4-2 & 40 & 46 & 14 & & & 0.33 \\
\hline $\mathrm{SC} 4 \cdot 4$ & & 74 & 24 & 2 & & 0.38 \\
\hline $\mathrm{SC} 4.7$ & 56 & 32 & 12 & & & 0.30 \\
\hline SC4-12 & 32 & 62 & 6 & & & 0.33 \\
\hline SR1-2 & 12 & 68 & 20 & & & 0.85 \\
\hline TRI-1 & & 30 & 46 & 24 & & 0,44 \\
\hline WC1 -8 & 6 & 78 & 14 & 2 & & 0.36 \\
\hline WC1-4 & & 66 & 30 & 4 & & 0.38 \\
\hline WC2-4 & & 18 & 64 & 18 & & 0.45 \\
\hline WC2.9 & & 56 & 38 & 6 & & 0.38 \\
\hline WC2-10 & & 36 & 54 & 10 & & 0.42 \\
\hline WC2-14 & & 64 & 34 & 2 & & 0.38 \\
\hline
\end{tabular}

Table B-4. Relationship between rank and vitrinite reflectance. Modified from Rao, 1976 and Ting, 1978. By this classification, all Susilna lowland coais are subbituminous.

Rank
Lignite
Subbituminous coal
High-volatile bituminous coal
Medium-volatile bituminous coa
Low-volatile bituminous coal
Semiantliracite
Anthracite
Meta-anthracite

Reflectance

( $\bar{R} \circ \mathrm{m}, \%)$

$0.20-0.30$

$0.30 \cdot 0.60$

$0.50-1.0$

$1.0-1.5$

$1.6 \cdot 2.0$

$2.0-2.6$

$2.5 \cdot 5.0$

$>5.0$ 
Table B-5. Colculations relating to conl quality.

\begin{tabular}{|c|c|c|c|c|c|c|c|c|c|c|}
\hline Sample & $\begin{array}{l}\text { Carbon } \\
\text { ratio }\end{array}$ & $\begin{array}{l}\text { Perch \& Russell } \\
\text { ratiob }\end{array}$ & $\begin{array}{l}\text { Fuel } \\
\text { ratio }\end{array}$ & $\begin{array}{l}\text { H value of } \\
\text { Lordd } \\
\text { (Btu/lb) }\end{array}$ & $\begin{array}{c}\text { Dry. mm-free } F C \\
(\%)^{\mathrm{e}}\end{array}$ & $\begin{array}{c}\text { Dry, mm free VM } \\
(\%)^{f}\end{array}$ & $\begin{array}{c}\text { Moist, mm-iree Btu } \\
(\text { per lb })^{g}\end{array}$ & $\begin{array}{l}\text { Apparent } \\
\text { rank }\end{array}$ & $\begin{array}{c}\text { Mineral matter } \\
(\%)^{h}\end{array}$ & $\begin{array}{l}\text { DuLong's } \\
\text { equation } \\
\text { (Btu/lb) }\end{array}$ \\
\hline $8 B 1-1$ & 50.4 & 0.82 & 1.02 & 11.510 & 50.9 & 49.1 & 9,880 & Subbit $\mathrm{B}$ & 9.1 & \\
\hline BP1-1 & 40.6 & 0.85 & 0.68 & 10,627 & 42.1 & 58.9 & 9,650 & Subbit B & 12.2 & 9,010 \\
\hline BRl.4 & 41.0 & 0.82 & 0.69 & 10,476 & 41.3 & 58.7 & 9.270 & Subbit C & 8.1 & \\
\hline $\mathrm{BR}-\beta$ & 41.9 & 0.82 & 0.72 & 10,501 & 42.5 & 57.5 & 9,400 & Subbit C & 11.7 & \\
\hline BRI-12 & 40.4 & 0.81 & 0.68 & 10,143 & 41,0 & 59.0 & 9,240 & Subbitc & 12.8 & \\
\hline$B \pi 1-15$ & 41.7 & 0.62 & 0.72 & 10,069 & 42.2 & 57.8 & 9.200 & Subbit C & 11.4 & \\
\hline $\mathrm{CpCl} \cdot 1$ & 43.2 & 0.83 & 0.76 & 11.354 & 46.6 & 53.4 & 9,820 & Subbit B & 2.6 & \\
\hline $\mathrm{CnCl} \cdot \mathrm{I}$ & 49.6 & 0.87 & 0.98 & 11,336 & 50.0 & 50.0 & 10.480 & Subbit B & 9.5 & \\
\hline $\mathrm{CnC2}-1$ & 48.7 & 0.84 & 0.95 & 10.827 & 49.4 & 50.6 & 9,570 & Subbit B & 14.0 & \\
\hline $\mathrm{CrCA}_{-1}$ & 49.2 & 0.85 & 0.97 & 11,621 & 49.6 & 50.4 & 10.270 & Subbic B & 8.9 & \\
\hline $\mathrm{CnC} 6 \cdot 1$ & 45.8 & 0.82 & 0.85 & 11,135 & 46.2 & 53.8 & 10,070 & Subbit B & 8.4 & \\
\hline $\mathrm{CnC} 7.1$ & 49.2 & 0.86 & 0.97 & 9,833 & 49.6 & 50.4 & 9,930 & Subbit B & 7.2 & 9.800 \\
\hline $\mathrm{CnCs}-2$ & 49.2 & 0.86 & 0.97 & 10,800 & 49.7 & 50.3 & 10,180 & Subbit B & 9.4 & 9.820 \\
\hline $\operatorname{cc} 3 \cdot 1$ & 48.7 & 0.77 & 0.95 & 10,583 & 49.0 & 51.0 & 9.050 & Subbit C & 6.4 & \\
\hline $\cos 3-2$ & 46.6 & 0.82 & 0.87 & 10,342 & 47.5 & 52.5 & 9.750 & Subbit B & 16.5 & \\
\hline $\operatorname{cc} 3-3$ & 47.4 & 0.78 & 0.90 & 7,620 & 48.0 & 52.0 & 9,490 & Subbit C & 10.0 & \\
\hline $\cos 34$ & 44.9 & 0.78 & 0.81 & 9,762 & 45.4 & 54.6 & 9,240 & Subbit C & 10.9 & \\
\hline $\cos 1-1$ & 47.4 & 0.76 & 0.90 & 10,265 & 47.8 & 52.2 & 9050 & Subbit C & 8.0 & \\
\hline $\cos 3-10$ & 39.7 & 0.76 & 0.66 & 8,072 & 41.8 & 58,2 & 8,490 & Subbit C & 33.8 & 6,650 \\
\hline $\operatorname{CG}_{4} \cdot 1$ & 48.8 & 0.82 & 0.95 & 9,971 & 50.3 & 49.7 & 9,430 & Subbit C & 24.1 & 8,020 \\
\hline $\mathrm{CGA}-2$ & 46.6 & $\ldots$ & 0.87 & $\ldots$ & & $\ldots$ & $\ldots$ & $\ldots$ & $\ldots$ & \\
\hline CG4-3 & 46.0 & 0.80 & 0.85 & 10,203 & 46.6 & 53.4 & 9,490 & Subbitc & 9,8 & \\
\hline CG4-4 & 50.2 & $0.8 \mathrm{I}^{\mathrm{i}}$ & 1.01 & 11,482 & 51.4 & $48.6^{j}$ & 9380 & Subbit $c^{i}$ & 19.4 & \\
\hline CG4-5 & 47.0 & $0.81^{j}$ & 0.89 & 11,599 & $48.1^{j}$ & $51.9^{j}$ & 9,500 & Subbit B & 20.1 & \\
\hline CR3-1 & 52.6 & 0.83 & 1.11 & 11,435 & 53.6 & 46.4 & 9.990 & Subbit B & 17.8 & \\
\hline CR5.1 & 45.3 & 0.82 & 0.83 & 9,223 & 45.9 & 54.1 & 9.370 & Subbit C & 11.7 & \\
\hline $\operatorname{CR} 5 \cdot 3$ & 44.6 & 0.83 & 0.80 & 9,879 & 44.9 & 55.1 & 9,660 & Subbit B & 7.1 & \\
\hline CR6-1 & 46.1 & 0.85 & 0.86 & 9,606 & 466 & $53-4$ & 9,190 & Subbit C & 109 & \\
\hline CR9-1 & 46.5 & 0.84 & 0.87 & 10,635 & 47.0 & 530 & 9,760 & Subbit B & 9.9 & \\
\hline CRg-3 & 46.0 & $0.8 \mathbf{5}$ & 0.85 & 10,375 & 46.5 & 53.5 & 9,940 & Subbit B & 11.4 & 9,280 \\
\hline CRlo-1 & 47.3 & 0.84 & 0.90 & 11,447 & 48.4 & 52.6 & 10.160 & Subbil B & 20.9 & 8,810 \\
\hline $\mathrm{DCl}-1$ & 51.3 & 0.84 & 1.05 & 11,415 & 51.8 & 48.2 & 10.030 & Subbit B & 10.0 & \\
\hline $\mathrm{DC} 1,2$ & 48.2 & 0.83 & 0.93 & 11,282 & 49.2 & 50.8 & 9,930 & Subbit B & 18.0 & \\
\hline FMl.2 & 47.5 & 0.85 & 0.90 & 9,736 & 50.4 & 49.6 & 9,580 & Subbit B & 39.6 & \\
\hline FMI 4 & 47.1 & 0.84 & 0.89 & 9,986 & 48.8 & 51.2 & 9620 & Subbit B & 28.5 & \\
\hline FM1-7 & 50.5 & 0.85 & 0.99 & $10,4,4$ & 50.6 & 49.4 & 9,870 & Subbit B & 16.1 & 8.950 \\
\hline FMI-10 & 46.7 & 0.84 & 0.88 & 10,240 & 48.4 & 51.6 & 9.590 & Subbit B & 26.1 & \\
\hline FM 13 & 44.9 & 0.81 & 0.91 & 11,087 & 45.9 & 54,1 & 10.830 & Subbit $A$ & 20.2 & \\
\hline FMO-1 & 42,2 & 0.80 & 0.73 & 10,450 & 4.2 .7 & 57.3 & 8.870 & Subbil C & 12.5 & \\
\hline$F M 2-2$ & 43.3 & 0.85 & 0.76 & 10,663 & 43.7 & 56.3 & 9,850 & Subbit B & 10.0 & \\
\hline$F M 2-6$ & 36.8 & 0.93 & 0.58 & 9.022 & 41.0 & 59.0 & 10,350 & Subbil B & $\$ 6.0$ & \\
\hline FrCl.J & 47.0 & 0.84 & 3.13 & 10,529 & 48.2 & 51.8 & 9.900 & Subbit $\mathrm{E}$ & 21.5 & \\
\hline $\mathrm{JC2} 2 \cdot 2$ & 54.5 & 0.85 & 1.20 & 8,995 & 54.9 & 43.1 & 10,240 & Subbil B & 6.3 & \\
\hline $\operatorname{dC3}-1$ & 42.1 & 0.84 & 0.73 & 9,841 & 42.9 & 57.1 & 8.770 & Subbit C & 16.7 & 8,270 \\
\hline JCs-5 & 45.3 & 0.85 & 0.83 & 8,361 & 46.3 & 53.7 & 9630 & Subbit B & 18.9 & \\
\hline PA1-5 & 4.5 .4 & 0.83 & 0.83 & 8,909 & 46.2 & 53.8 & 9,040 & Subbit B & 14.7 & \\
\hline PA. $1-32$ & 40.1 & 0.82 & 0.67 & 10,509 & 40.6 & 59.4 & 10,260 & Subbit B & 12.0 & \\
\hline PA1-34 & 36.8 & 0.92 & 0.58 & 10,288 & 38.4 & 61.6 & 11,100 & Subbit A & 33.9 & \\
\hline
\end{tabular}




\begin{tabular}{|c|c|c|c|c|c|c|c|c|c|}
\hline$Z A 2-1$ & 39.6 & 0.75 & 0.66 & 9,744 & 40.6 & 59.4 & 8,660 & Subbit C & 22.2 \\
\hline PA3-1 & 41.2 & 0.85 & 0.70 & 8,170 & 42.9 & 57.1 & 9,430 & Subbit C & 29.8 \\
\hline PA3-3 & 43.5 & 0.82 & 1.30 & 7,927 & 44.8 & 55.2 & 9,270 & Subbit C & 23.0 \\
\hline SC2-2 & 46.5 & 0.83 & 0.87 & 9,872 & 46.9 & 53.1 & 9,210 & Subbjt C & 7.7 \\
\hline $\sec 2-3$ & 49.7 & 0.84 & 0.99 & 10.727 & 50.0 & 50.0 & 9,670 & Subbit $\mathrm{B}$ & 6.7 \\
\hline$S C 3 \cdot 1$ & 47.9 & 0.80 & 0.92 & 10,638 & 49.1 & 50.9 & 9,600 & Subbit B & 21.2 \\
\hline $\mathrm{SC} 4-2$ & 46.2 & 0.83 & 0.86 & 9,738 & 46.6 & 53.4 & 9.190 & Subbit $\mathrm{C}$ & 9.1 \\
\hline $\mathrm{SC} 4-4$ & 47.1 & 0.84 & 0.89 & 10,553 & 47.5 & 52.5 & 9,700 & Subbit B & 7.2 \\
\hline $\mathrm{SC} 4.7$ & 50.9 & 0.82 & 1.04 & $10,45 \mathrm{I}$ & 51.1 & 48.9 & 9,790 & Subbit B & 3.3 \\
\hline SC4.12 & 46.5 & 0.80 & 0.87 & 10,553 & 47.8 & 52.2 & 9.620 & Subbit B & 22.2 \\
\hline SR $1 \cdot 2$ & 50.5 & 0.83 & 1.02 & 8,186 & 51.9 & 48.1 & 9,560 & Subbit $\mathrm{B}$ & 24,4 \\
\hline TR1-1 & 51.1 & 0.81 & 1.04 & 12,521 & 51.4 & 48.6 & 11,500 & Subbit A. & 4.8 \\
\hline WC1-3 & 541 & 0.84 & 1.18 & 9,277 & 54.7 & 45.3 & 10.230 & Subbit B & 8.8 \\
\hline$W C l=4$ & 44.0 & 0.82 & 0.78 & 9,013 & 46.0 & 54.0 & 3,660 & Subbit B & 32.2 \\
\hline WC2-4 & 47.9 & 0.82 & 0.92 & 9,232 & 49.5 & 50.5 & 9.840 & Subbit 5 & 25.3 \\
\hline WC2-9 & 49.7 & 0.84 & 0.99 & 13,688 & 51.7 & 48.3 & 13,090 & Hv 8 bit & 29.5 \\
\hline WC2-10 & 49.7 & 0.83 & 0.99 & 11,118 & 50.9 & 49.1 & 10,090 & Subbjt B & 20.5 \\
\hline WC2-14 & 49.6 & 0.82 & 0.98 & 10,004 & 51.3 & 48.7 & 9,710 & Subbit B & 26.4 \\
\hline
\end{tabular}

$\frac{F C}{F C+V M} \times 100$

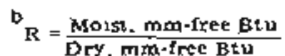

$\frac{c_{F C}}{V M}$

${ }_{H}=\frac{\sin -4050 S}{100-(M+A+S)} \times 100$

" $\frac{F C \cdot 0.165}{100 \cdot(M+1.08 \mathrm{~A}+0.555)} \times 100$

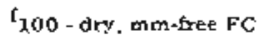

$\frac{5+4}{200-(1.0 \overline{0} A+0.555)} \times 100$

$\mathbf{h}_{\mathrm{MM}}=$

$1.08 \mathrm{~A}+0.55 \mathrm{~S}$

$[100-(1.08 \mathrm{~A}+0.55 \mathrm{~S})] / 1.35+(1.0 \mathrm{BA}+0.55 \$) / 2.8$

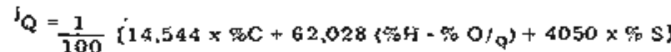

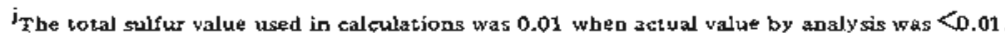


Table B-6. Classification of coals by rank. From ASTM, 1981.

\begin{tabular}{|c|c|c|c|c|c|c|c|c|}
\hline \multirow[t]{2}{*}{ Class } & Group & \multicolumn{2}{|c|}{$\begin{array}{l}\text { Fixed carbon } \\
\text { limits, percent } \\
\text { (dry, minera! } \\
\text { matter-free basis) }\end{array}$} & \multicolumn{2}{|c|}{$\begin{array}{l}\text { Volatile mather limits, } \\
\text { percent (dry, mineral- } \\
\text { matter-free basis) }\end{array}$} & \multicolumn{2}{|c|}{$\begin{array}{l}\text { Calorific value limits, } \\
\text { Btu per pouad } \\
\text { (moist, }{ }^{c} \text {, mineral- } \\
\text { matter-free basis) }\end{array}$} & \multirow[t]{2}{*}{ Agglomeraling character } \\
\hline & & $\begin{array}{c}\text { Equal or } \\
\text { Ereater } \\
\text { than } \\
\end{array}$ & $\begin{array}{l}\text { Less } \\
\text { than }\end{array}$ & $\begin{array}{c}\text { Greater } \\
\text { than } \\
\end{array}$ & $\begin{array}{l}\text { Equal ot } \\
\text { less than }\end{array}$ & $\begin{array}{l}\text { Equal or } \\
\text { greater } \\
\text { than } \\
\end{array}$ & $\begin{array}{l}\text { Less } \\
\text { than }\end{array}$ & \\
\hline \multirow{3}{*}{ I. Anthracitic } & 1. Meta-anthracite & 98 & $\cdots$ & $\cdots$ & 2 & $\cdots$ & $\cdots$ & \multirow{3}{*}{ Nonaggiomerating } \\
\hline & 2. Anthracite & 92 & 98 & 2 & 8 & $\cdots$ & $\cdots$ & \\
\hline & 3. Semianthracite & 86 & 92 & 8 & 14 & $\cdots$ & 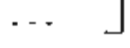 & \\
\hline \multirow{6}{*}{ Bituminous } & 1. Low wolatile bituminous coal & 78 & 86 & 14 & 22 & $\cdots$ & $\cdots$ & \multirow{6}{*}{ - Commonly agglomerating ${ }^{\mathrm{e}}$} \\
\hline & 2. Medium volatile bituminous coal & 69 & 78 & 22 & 31 & $\ldots$ & $\ldots$ & \\
\hline & 3. High volatile A bituminous coal & $\ldots$ & 69 & 31 & $\cdots$ & $14000^{1}$ & $\ldots$ & \\
\hline & 4. High volatile B bituminous coal & $\cdots$ & $\ldots$ & $\ldots$ & $-\cdots$ & $13000^{f}$ & 14000 & \\
\hline & 5. High volatile $\mathrm{C}$ bituminous coal & $\cdots$ & ... & $\cdots$ & $\cdots$ & 11500 & 13000 & \\
\hline & & & & & & 10500 & 11500 & \\
\hline \multirow{3}{*}{ - Subbituminous } & 1. Subbituminous A coal & $\cdots$ & $\cdots$ & $\cdots$ & $\cdots$ & 10500 & $11500^{\circ}$ & \multirow{5}{*}{ - Nonagglomerating } \\
\hline & 2. Subbituminous B coal & $-\cdots$ & - - - & $\cdots$ & $\cdots$ & 9500 & 10500 & \\
\hline & 3. Subbituminous C coal & $\cdots$ & $\cdots$ & $\cdots$ & $\cdots$ & 8300 & 9500 & \\
\hline \multirow[t]{2}{*}{. Lignitic } & 1. Lignite A & $\cdots$ & $\cdots$ & $\cdots$ & .. & 6300 & 8300 & \\
\hline & 2. Lignite B & $\cdots$ & $\cdots$ & - - & - . & $\ldots$ & $\begin{array}{lll}6 & 300\end{array}$ & \\
\hline
\end{tabular}

Fhis classification does not inclucie a few cozls, princupally noxbasded varieties, which have unusual physical and chemucal properties and which come within the limits of fixce carbon or calorifte value of the high-volatile bituminous and subbtuminous ranks. All of these coals either contain less than 48\% dry", minexal-malter-free fixed carbon or have more than 15.500 moist b ameral-mate

1. Stadadard specifications for classification of cols by rank (ASTM designation D-388-77): 1981 Anoual book of ASTM stapdards, part 26. p. $212-216$.

Moist refers 10 coal containiog its natural inherent moisture but nol including visible water on the surface of the coal.

(2) bituminous class.

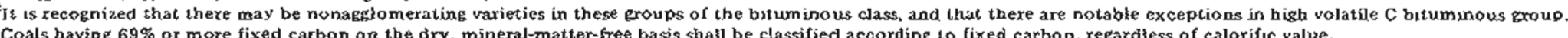

Coals havine $69 \%$ or more fixed carbon an the dry, mineral-matter-free basis shasl be classified according to fired carbon, regardiess of calorific value. 
Table B-7. Tolal suifur, selected Susitna lowland coal samples.

\begin{tabular}{|c|c|c|c|}
\hline \multirow[b]{2}{*}{ Sample } & \multicolumn{3}{|c|}{ Total sulfur $(\%)$} \\
\hline & $1^{2}$ & 2 & 3 \\
\hline BRl-4 & 0.16 & 0.19 & 0.21 \\
\hline $\mathrm{BKl}-8$ & 0.19 & 0.28 & 0.26 \\
\hline BR1-12 & 0.22 & 0.26 & 0.30 \\
\hline BRI-15 & 0.21 & 0.26 & 0.28 \\
\hline BR1-1 & 0.10 & 0.12 & 0.14 \\
\hline $\mathrm{CpC1-1}$ & 0.08 & 0.09 & 0.09 \\
\hline $\mathrm{CnCl}-1$ & 0.14 & 0.16 & 0.18 \\
\hline $\mathrm{CnC} 2 \cdot 1$ & 0.11 & 0.18 & 0.15 \\
\hline $\mathrm{CnC} 4-1$ & 0.09 & 0.10 & 0.11 \\
\hline $\mathrm{CnC} 6.1$ & 0.11 & 0.13 & 0.15 \\
\hline CG1-1 & 0.23 & 0.29 & 0.32 \\
\hline $\mathrm{CO} 3-10$ & 0.40 & 0.48 & 0.66 \\
\hline $\operatorname{CG} 4-3$ & 0.31 & 0.38 & 0.43 \\
\hline$C G 4.4$ & $<0.01$ & $<0.01$ & $<0,01$ \\
\hline $\operatorname{CG} 4-5$ & $<0.01$ & $<0.01$ & $<0.01$ \\
\hline CRB-1 & 0.11 & 0.13 & 0.16 \\
\hline CR5-1 & 0.41 & 0.49 & 0.57 \\
\hline CR5-3 & 0.34 & 0.40 & 0.44 \\
\hline CR6-1 & 0.23 & 0.27 & 0.30 \\
\hline CR9-1 & 0.19 & 0.23 & 0.26 \\
\hline CCs-1 & 0.21 & 0.27 & 0.29 \\
\hline CC3.2 & 0.27 & 0.32 & 0.39 \\
\hline CCB-3 & 0.73 & 0.91 & 1.03 \\
\hline $\mathrm{CC} 3-4$ & 0.35 & 0.44 & 0.50 \\
\hline$D C 1-1$ & 0.09 & 0.11 & 0.12 \\
\hline $\mathrm{DCl}-2$ & 0.11 & 0.13 & 0.16 \\
\hline FM1-2 & $0.1 \theta$ & 0.21 & 0.36 \\
\hline FML-4 & 0.23 & 0.27 & 0.39 \\
\hline FM1-10 & 0.18 & 0.20 & 0.28 \\
\hline FM1-1a & 0.22 & 0.24 & 0.31 \\
\hline FM2-1 & 0.11 & 0.13 & 0.16 \\
\hline FM 2-2 & 0.17 & 0.19 & 0.22 \\
\hline FM2-6 & 0.22 & 0.23 & 0.53 \\
\hline FrCl-1 & 0.20 & 0.23 & 0.30 \\
\hline $\mathrm{JC2}-2$ & 0.61 & 0.71 & 0.76 \\
\hline JC3-5 & 0.52 & 0.61 & 0.76 \\
\hline PA1.5 & 0.47 & 0.56 & 0.66 \\
\hline PA1-32 & 0.36 & 0.44 & 0.50 \\
\hline PA1-34 & 0.28 & 0.30 & 0.46 \\
\hline PA2-1 & 0.30 & 0.35 & 0.47 \\
\hline $\mathrm{PAB}^{3}-1$ & 0.44 & 0.50 & 0.73 \\
\hline PA3-3 & 0.54 & 0.64 & 0.85 \\
\hline SC2-2 & 0.23 & 0.27 & 0.29 \\
\hline $\mathrm{SC} 2-3$ & 0.16 & 0.19 & 0.20 \\
\hline $\mathrm{SC} 4 \cdot 2$ & 0.26 & 0.31 & 0.35 \\
\hline $\mathrm{SC} 4-4$ & 0.20 & 0.23 & 0.26 \\
\hline SC4-7 & 0.31 & 0.38 & 0.39 \\
\hline SC4.12 & 0.24 & 0.29 & 0.39 \\
\hline SR1-2 & 0.53 & 0.63 & 0.85 \\
\hline TRI-1 & 0.82 & 0.40 & 0.42 \\
\hline WCl.s & 0.56 & 0.66 & 0.73 \\
\hline WC1-4 & 0.38 & 0,44 & 0.67 \\
\hline WC2-4 & 0.43 & 0.51 & 0.70 \\
\hline WC2.9 & 0.28 & 0.33 & 0.48 \\
\hline WC2.10 & 0.17 & 0.19 & 0.25 \\
\hline WC2-14 & 0.25 & 0.30 & 0.42 \\
\hline
\end{tabular}


Table B.8. Sulfur species, selected Susitna lowland coals (\%).

\begin{tabular}{|c|c|c|c|c|c|c|c|c|c|c|c|c|}
\hline \multirow[b]{2}{*}{ Sample } & \multicolumn{3}{|c|}{ Organic } & \multicolumn{3}{|c|}{ Pyritic } & \multicolumn{3}{|c|}{ Sulfate } & \multicolumn{3}{|c|}{ Total } \\
\hline & $1^{\mathrm{a}}$ & 2 & 3 & 1 & 2 & 3 & 1 & 2 & 3 & 1 & 2 & 3 \\
\hline $\mathrm{BR} 1 \cdot 1$ & 0.12 & 0.14 & 0.16 & 0.01 & 0.01 & 0.01 & 0.01 & 0.01 & 0.01 & 0.14 & 0.16 & 0.18 \\
\hline $\mathrm{CnC7-1}$ & 0.31 & 0.37 & 0.39 & 0.01 & 0.01 & 0.01 & 0.03 & 0.03 & 0.04 & 0.35 & 0.41 & 0.44 \\
\hline $\mathrm{CnC} 8-2$ & 0.20 & 0.23 & 0.25 & $<0.01$ & $<0.01$ & $<0.01$ & 0.01 & 0.01 & 0.01 & 0.21 & 0.24 & 0.26 \\
\hline CG3-10 & 0.15 & 0.20 & 0.31 & 0.01 & 0.01 & 0.02 & 0.03 & 0.03 & 0.05 & 0.19 & 0.24 & 0.38 \\
\hline CG4-1 & 0.20 & 0.23 & 0.31 & 0.01 & 0.01 & 0.02 & 0.03 & 0.04 & 0.05 & 0.24 & 0.28 & 0.38 \\
\hline CR9.1 & 0.18 & 0.22 & 0.25 & $<0.01$ & $<0.01$ & $<0.01$ & 0.01 & 0.01 & 0.01 & 0.18 & 0.23 & 0.26 \\
\hline CR9-3 & 0.23 & 0.27 & 0.30 & $<0.01$ & $<0,01$ & $<0.01$ & 0.02 & 0.02 & 0.03 & 0.25 & 0.29 & 0.33 \\
\hline CP10-1 & 0.10 & 0.11 & 0.15 & $<0.01$ & $<0.01$ & $<0.01$ & 0.00 & 0.00 & 0.00 & 0.10 & 0.11 & 0.15 \\
\hline FM1-2 & 0.13 & 0.14 & 0.25 & 0.01 & 0.01 & 0.02 & 0.05 & 0.06 & 0.09 & 0.19 & 0.21 & 0.36 \\
\hline FMI-4 & 0.20 & 0.24 & 0.34 & 0.01 & 0.01 & 0.02 & 0.02 & 0.02 & 0.03 & 0.23 & 0.27 & 0.39 \\
\hline FM1-7 & 0.14 & 0.16 & 0.19 & 0.02 & 0.02 & 0.03 & 0.04 & 0.05 & 0.05 & 0.20 & 0.23 & 0.27 \\
\hline FM1-10 & 0.17 & 0.19 & 0.26 & 0.01 & 0.01 & 0.02 & $<0.01$ & $<0.01$ & $<0.01$ & 0.18 & 0.20 & 0.28 \\
\hline FMl-13 & 0.21 & 0.23 & 0.30 & 0.01 & 0.01 & 0.01 & $<0.01$ & $<0.01$ & $<0.01$ & 0.22 & 0.24 & 0.31 \\
\hline FMZ-2 & 0.15 & 0.17 & 0.20 & 0.01 & 0.01 & 0.01 & 0.01 & 0.01 & 0.01 & 0.17 & 0.19 & 0.22 \\
\hline FM2-6 & 0.21 & 0.22 & 0.51 & 0.01 & 0.01 & 0.02 & $<0.01$ & $<0.01$ & $<0.01$ & 0.22 & 0.23 & 0.63 \\
\hline JC3-1 & 0.18 & 0.22 & 0.26 & 0.02 & 0.02 & 0.03 & 0.05 & 0.06 & 0.07 & 0.25 & 0.30 & 0.36 \\
\hline $\mathrm{SC} 2 \cdot 2$ & 0.18 & 0.21 & 0.22 & 0.02 & 0.02 & 0.03 & 0.03 & 0.04 & 0.04 & 0.23 & 0.27 & 0.29 \\
\hline $\mathrm{SC} 2-3$ & 0.11 & 0.13 & 0.14 & 0.01 & 0.01 & 0.01 & 0.04 & 0.05 & 0.05 & 0.16 & 0.19 & 0.20 \\
\hline SC3-1 & 0.18 & 0.22 & 0.29 & 0.01 & 0.01 & 0.02 & 0.08 & 0.04 & 0.05 & 0.22 & 0.27 & 0.36 \\
\hline $\mathrm{SC} 4.2$ & 0.24 & 0.29 & 0.33 & 0.01 & 0.01 & 0.01 & 0.01 & 0.01 & 0.01 & 0.26 & 0.31 & 0.85 \\
\hline SC4-4 & 0.18 & 0.21 & 0.23 & 0.01 & 0.01 & 0.01 & 0.01 & 0.01 & 0.01 & 0.20 & 0.23 & 0.26 \\
\hline SR1-2 & 0.40 & 0.48 & 0.64 & 0.01 & 0.01 & 0.02 & 0.12 & 0.14 & 0.19 & 0.53 & 0.63 & 0.86 \\
\hline TR1-1 & 0.31 & 0.39 & 0.41 & $<0.01$ & $<0.01$ & $<0.01$ & 0.01 & 0.01 & 0.01 & 0.32 & 0.40 & 0.42 \\
\hline WC1-9 & 0.19 & 0.22 & 0.24 & 0.04 & 0.06 & 0.05 & 0.33 & 0.39 & 0.44 & 0.56 & 0.66 & 0.79 \\
\hline WC2-10 & 0.15 & 0.17 & 0.23 & 0.01 & 0.01 & 0.01 & 0.01 & 0.01 & 0.01 & 0.17 & 0.19 & 0.25 \\
\hline
\end{tabular}

${ }^{2} 1$ - As received; 2 - molsture frec: 3 - molsture and ash freo.

Table B-9. Ash (\%) and chemical analyses on coal from the Beluga field, as received basis (ppm). From Canwell, $1977 \mathrm{~b}$.

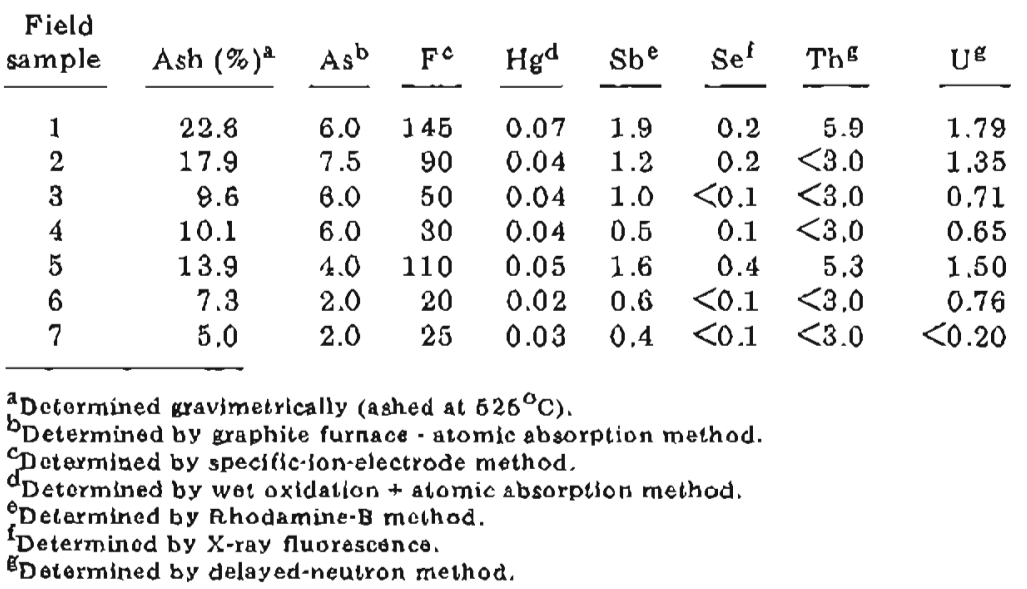


Table B-10. Chemical analyses on coal ash, mojor oxides, and chlorine (\%) of coal from the Beluga field. From Conwell, $1977 \mathrm{~b}$.

\begin{tabular}{|c|c|c|c|c|c|c|c|c|c|c|c|c|}
\hline $\begin{array}{l}\text { Field } \\
\text { sample }\end{array}$ & $\mathrm{Al}_{2} \mathrm{O}_{3}$ & $\mathrm{SiO}_{2}$ & $\mathrm{CaO}$ & $\mathrm{P}_{2} \mathrm{O}_{5}$ & $\mathrm{TiO}_{2}$ & $\mathrm{MnO}$ & $\mathrm{Fe}_{2} \mathrm{O}_{3}$ & $\mathrm{~K}_{2} \mathrm{O}$ & $\mathrm{MgO}$ & $\mathrm{Na}_{2} \mathrm{O}^{\mathrm{a}}$ & $\mathrm{SO}_{3}$ & $\mathrm{Cl}$ \\
\hline 1 & 27 & 51 & 3.0 & $<1.0$ & 0.87 & 0.05 & 3.8 & 2.40 & 1.18 & 0.17 & 2.6 & 0.20 \\
\hline 2 & 28 & $4 \bar{T}$ & 5.6 & $<2.0$ & 0.85 & 0.05 & 3.4 & 2.20 & 1.36 & 0.19 & 3.1 & 0.20 \\
\hline 3 & 25 & 33 & 13.0 & 1.2 & 0.84 & 0.05 & 4.3 & 1.20 & 1.46 & 0.19 & 7.6 & 0.20 \\
\hline 4 & 30 & 32 & 11.0 & $<1.0$ & 1.40 & 0.05 & 4.2 & 0.32 & 0.91 & 0.10 & 7.8 & 0.20 \\
\hline 5 & 23 & 44 & 6.3 & 1.4 & 1.20 & 0.05 & 3.6 & 1.90 & 3.20 & 0.23 & 3.0 & 0.20 \\
\hline 6 & 19 & 22 & 13.0 & 1.3 & 0.91 & 0.05 & 5.6 & 0.91 & 4.95 & 0.17 & 18.0 & 0.20 \\
\hline 7 & 21 & 21 & 17.0 & $<2.0$ & 0.84 & 0.05 & 3.0 & 0.83 & 5.53 & 0.18 & 15.0 & 0.20 \\
\hline
\end{tabular}

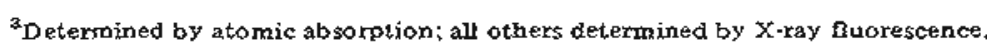

Table B-1 1. Proximate analyses, ultimate analyses, and calorific value of coal from the Beluga field. From Conwell, $1977 \mathrm{~b}$.

\begin{tabular}{|c|c|c|c|c|c|c|c|c|c|c|c|}
\hline \multirow[b]{2}{*}{$\begin{array}{c}\text { Field } \\
\text { somple }\end{array}$} & \multirow[b]{2}{*}{ Condition ${ }^{a}$} & \multicolumn{4}{|c|}{ Proximate analyses $(\%)$} & \multicolumn{5}{|c|}{ Uhtimate analyses (\%) } & \multirow{2}{*}{$\begin{array}{c}\text { Calorific } \\
\text { vahe } \\
\text { (Btu) }\end{array}$} \\
\hline & & Moisture & $\begin{array}{l}\text { Volatile } \\
\text { matter }\end{array}$ & $\begin{array}{l}\text { Fixed } \\
\text { carbon }\end{array}$ & Ash & Hydrogen & Carbon & Nitrogen & Oxygen & Sulfur & \\
\hline 17 & 1 & 7.0 & 41.1 & 360 & 15.9 & 5.2 & 53.3 & 0.7 & 24.7 & 0.2 & 9,160 \\
\hline 2 - combined & 2 & 19.9 & 35.4 & 31.0 & 13.7 & 6.0 & 46.0 & 0.6 & 33.6 & 0.1 & 7,900 \\
\hline 3 & 3 & $\cdots$ & 44.2 & 38.7 & 17.1 & 4.8 & 57.4 & 0.7 & 39.8 & 0.2 & 9,860 \\
\hline 4] & 4 & $\cdots$ & 53.3 & 46.7 & $-\cdots$ & 5.8 & 69.2 & 0.9 & 23.9 & 0.2 & 11,890 \\
\hline & I & 7.6 & 43.0 & 41.2 & 8.2 & 5.4 & 58.2 & 1.1 & 26.9 & 0.2 & 9,910 \\
\hline 5$]$ & 2 & $2 \pi .1$ & 36.7 & 35.2 & 7.0 & 6.3 & 49.7 & 0.9 & 36.0 & 0.1 & 8,460 \\
\hline $6-$ combined & 3 & $\ldots$ & 46.5 & 44.6 & 8.9 & 4.9 & 63.0 & 1.1 & 21.9 & 0.2 & 10,730 \\
\hline 7$\rfloor$ & 4 & $\cdots$ & 51.1 & 48.9 & $-\cdots$ & 5.4 & 69.2 & 1.3 & 23.9 & 0.2 & 11,780 \\
\hline
\end{tabular}

$a_{1}$ - air dried; 2 - as received; 3 - moisture free; 4 - moisture and ash free. 
Table B-12. Chemical analyses on coal-ash trace elements $(p p m)$ in coal from the Beluga field. From Conwell, $1977 b$.

\begin{tabular}{|c|c|c|c|c|c|c|c|c|c|c|c|c|c|c|c|c|c|c|c|c|c|c|}
\hline $\begin{array}{l}\text { Field } \\
\text { sample }\end{array}$ & $\mathrm{B}$ & $\mathrm{Ba}$ & $\mathrm{Be}$ & $\mathrm{Cd}^{\mathrm{a}}$ & Co & $\mathrm{Cr}$ & $\mathrm{Cu}^{\mathrm{a}}$ & $\mathrm{Ga}$ & La & $\mathrm{Li}^{\mathrm{a}}$ & $M n^{a}$ & Mo & $\mathrm{Nb}$ & $\mathrm{Ni}$ & $\mathrm{Pb}^{\mathrm{a}}$ & $\mathrm{Sc}$ & $\mathrm{Sx}$ & $\mathrm{V}$ & $\mathbf{Y}$ & $Y \mathrm{~b}$ & $\mathrm{Z} n^{\mathrm{a}}$ & $\mathrm{Zr}$ \\
\hline 1 & 70 & 3,000 & 7 & $<1$ & 30 & 300 & 131 & 70 & 100 & 89 & 465 & 150 & 20 & 70 & 60 & 50 & 1,500 & 700 & 100 & 10 & 139 & 150 \\
\hline 2 & 100 & 5,000 & 30 & $<1$ & 50 & 300 & 115 & 70 & $<100$ & 85 & 345 & 30 & 20 & 70 & 50 & 30 & 700 & 500 & 70 & 10 & 140 & 200 \\
\hline 4 & 50 & 5,000 & 10 & $<1$ & 50 & 100 & 104 & 70 & 100 & 54 & 485 & 30 & 30 & 100 & 40 & 50 & 1,000 & 300 & 150 & 15 & 148 & 300 \\
\hline 5 & 150 & 10,000 & 10 & $<1$ & 50 & 300 & 239 & 70 & 100 & 54 & 310 & 30 & 30 & 100 & 40 & 50 & 1,000 & 700 & 100 & 15 & 90 & 150 \\
\hline 6 & 150 & 10,000 & 3 & $<1$ & 30 & 200 & 178 & 50 & $<100$ & 32 & 325 & 20 & 20 & 70 & 25 & 30 & 1,000 & 500 & 70 & 7 & 80 & 150 \\
\hline
\end{tabular}

Table B-13. Fusibility of ash and sulfur forms in coal from the Beluga fold. From Conwell, $1977 \mathrm{~b}$.

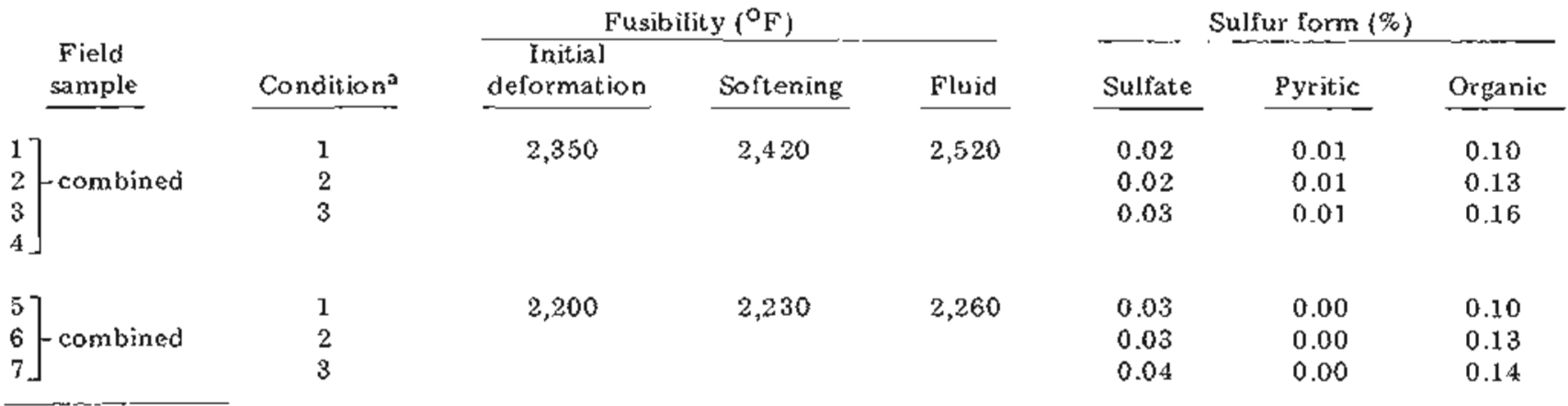

$\mathbf{a}_{1}$ - air dried, 2 - as received, 3 - moist ure free. 
Table B-14. Proximale analysis.

\begin{tabular}{|c|c|c|c|c|c|c|c|c|c|c|c|c|c|c|c|}
\hline \multirow[t]{2}{*}{ Sample } & \multicolumn{3}{|c|}{ Moisture (\%) } & \multicolumn{3}{|c|}{ Volatile matier (\%) } & \multicolumn{3}{|c|}{ Fixed carbon (\%) } & \multicolumn{3}{|c|}{ Ash (\%) } & \multicolumn{3}{|c|}{$\begin{array}{l}\text { Healing value } \\
\text { (Btu/lb) }\end{array}$} \\
\hline & $1^{\mathrm{n}}$ & 2 & 3 & 1 & 2 & 3 & 1 & 2 & 3 & 1 & 2 & 3 & 1 & 2 & 3 \\
\hline BRI-1 & 14.2 & $\cdots$ & $\cdots$ & 44.3 & 51.6 & 59.4 & 30.3 & 35.3 & 40.6 & 11.2 & 13.1 & $\cdots$ & 8480 & 9880 & 11370 \\
\hline $\mathrm{BR} 1-4$ & 17.2 & $\cdots$ & $\ldots$ & 44.5 & 53.7 & 59.0 & 30.9 & 37.3 & 41.0 & 7.4 & 9.0 & $\cdots$ & 8530 & 10300 & 11310 \\
\hline BR1-8 & 17.3 & $\cdots$ & $\cdots$ & 41.8 & 50.5 & 58.0 & 30.2 & 36.6 & 42.0 & 10.7 & 12.9 & $-\cdot$ & 8310 & 10060 & 11540 \\
\hline BR1-12 & 17.3 & $\cdots$ & $-\cdot$ & 42.3 & 61,1 & 59.5 & 28.7 & 35.8 & 40.5 & 11.7 & 14.1 & $\ldots$ & 8070 & 9750 & 11360 \\
\hline BR1-15 & 16.7 & $\ldots$ & $\cdots$ & 42.5 & 51.1 & 58.4 & 30.4 & 96.4 & 41.6 & 10.4 & 12.5 & $\cdots$ & 8170 & 9810 & 11220 \\
\hline BB1-1 & 17.0 & $\cdots$ & $\cdots$ & 37.0 & 44.6 & 49.7 & 37.6 & 45.2 & 50.3 & 8.4 & 10.2 & $\ldots$ & 8980 & 10820 & 12060 \\
\hline $\mathrm{CpCl}-1$ & 16.3 & $\ldots$ & $\ldots$ & 46.1 & 55.1 & 56.7 & 35.2 & 42.1 & 43.3 & 2.4 & 2.8 & $\cdots$ & 9570 & 11130 & 11770 \\
\hline $\mathrm{CnCl}-1$ & 12.4 & $\cdots$ & $\cdots$ & 40.3 & 48.0 & 50.4 & 39.7 & 45.3 & 49.6 & 7.6 & 8.7 & $\cdots$ & 9620 & 10980 & 12020 \\
\hline CnC2-1 & 15.0 & $\cdots$ & $\cdots$ & 37.0 & 43.5 & 51.4 & 35.1 & 41.3 & 48.6 & 12.9 & 15.2 & $\cdots$ & 8240 & 9700 & 11440 \\
\hline $\mathrm{CnC4}-1$ & 14.8 & $\cdots$ & $\cdots$ & 39.4 & 46.0 & 50.8 & 38.1 & 44.5 & 49.2 & 8.2 & 9.5 & $\ldots$ & 9360 & 10920 & 12070 \\
\hline $\mathrm{CnC6}-1$ & 18.3 & $\cdots$ & $\cdots$ & 42.8 & 48,3 & 54,1 & 36.2 & 41.9 & 45.9 & 7.7 & 8.8 & $\cdots$ & 9820 & 11830 & 12430 \\
\hline $\mathrm{CnC7} \cdot 1$ & 13.7 & $\cdots$ & $\cdots$ & 40.5 & 46.9 & 50.8 & 39.3 & 45.5 & 49.2 & 6.5 & 7.6 & $\cdots$ & 9230 & 10700 & 11570 \\
\hline $\mathrm{CnC} 8-2$ & 13.8 & $\cdots$ & $\cdots$ & 39.5 & 45.8 & 50.9 & 38.3 & 44.2 & 48.1 & 8.6 & 10.0 & $\cdots$ & 9230 & 10690 & 11870 \\
\hline CG1-1 & 20.3 & $\ldots$ & $\cdots$ & 38.1 & 47.8 & 52.6 & 34,3 & 43.0 & 47.4 & 7.3 & 9.2 & $\cdots$ & 8640 & 10840 & 11940 \\
\hline CG $3-10$ & 18.6 & $\cdots$ & $\therefore$ & 30.4 & 37.3 & 60.3 & 20.0 & 24.5 & 39.7 & 31.1 & 38.2 & . & 5640 & 6920 & 11190 \\
\hline CG4-I & 15.4 & $\ldots$ & $\cdots$ & 31.9 & 37.7 & 51.2 & 30.4 & 35.9 & 48.8 & 22.3 & 26.4 & $\ldots$ & 7160 & 8460 & 11490 \\
\hline CG4:2 & 15.1 & $\cdots$ & $-\cdot$ & 32.6 & 38.4 & 53.5 & 28,4 & 33.5 & 46.5 & 23.9 & 28.1 & $\cdot$ & 7080 & 8820 & 11580 \\
\hline CG4-3 & 19.0 & $\cdots$ & $\cdots$ & 98.9 & 48.0 & 54.0 & 33.2 & 41.0 & 46.0 & 8.9 & 11.0 & $\cdots$ & 8580 & 10600 & 11910 \\
\hline CG4-4 & 16.5 & $\cdots$ & $\cdots$ & 32.6 & 39.1 & 49.8 & 32.9 & 39.3 & 50.2 & 18.0 & 21.6 & . & 7560 & 9050 & 11540 \\
\hline $\mathrm{CQ} 4 \cdot 5$ & 16.3 & $\cdots$ & - & 34.5 & 41.2 & 53.0 & 30.6 & 36.6 & 47.0 & 18.6 & 22.2 & $\cdots$ & 7590 & 9070 & 11660 \\
\hline CR3-I & 16.5 & $\cdots$ & $\ldots$ & 32.3 & 38,2 & 47.4 & 35.8 & 42.8 & 52.6 & 16.4 & $1.9,6$ & $\cdots$ & 8220 & 8730 & 12090 \\
\hline CR5-1 & 17.0 & $\cdots$ & $\cdots$ & 39.6 & 47.7 & 64.7 & 32.8 & 39.5 & 45.3 & 10.6 & 12.8 & $\ldots$ & 8300 & 10000 & 11470 \\
\hline CR5-3 & 16.2 & $\cdots$ & $\cdots$ & 42.9 & 51.1 & 55.3 & 34.5 & 41.3 & 44.7 & 6.4 & 7.6 & $\ldots$ & 8990 & 10720 & 11600 \\
\hline CR6.1 & 14.1 & $\cdots$ & $\cdots$ & 40.9 & 47.7 & 53.8 & 35.0 & 40.7 & 46.1 & 10.0 & 11.6 & $\because$ & 8200 & 8550 & 10800 \\
\hline CR9-1 & 15.2 & -- & $\cdots$ & 40.6 & 47.7 & 58.5 & 35.2 & 41.6 & 46.5 & 9.1 & 10.7 & $\cdots$ & 8800 & 10380 & 11630 \\
\hline CR9-3 & 14.1 & 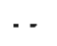 & $\cdots$ & 40.8 & 47.6 & 54.1 & 84.7 & 40.3 & 45.9 & 10.4 & 12.1 & $\cdots$ & 8820 & 10270 & 11670 \\
\hline CR10-1 & 13.9 & $\cdots$ & $\cdots$ & 35.2 & 40.9 & 52.7 & 31.6 & 36.7 & 47.3 & 19.3 & 22.4 & - & 8040 & 8350 & 12050 \\
\hline CC3.1 & 21.8 & $\cdots$ & $\cdots$ & 37.1 & 47.4 & 51.2 & 35.2 & 40.2 & 48.8 & 5.8 & 7.4 & $\cdots$ & 8480 & 10860 & 11720 \\
\hline $\mathrm{CC} \cdot 2$ & 16.3 & $\cdots$ & $\cdots$ & 36.6 & 49.7 & 53.3 & 32.0 & 38.3 & 46.7 & 15.1 & 18.0 & $\cdots$ & 8160 & 9750 & 11890 \\
\hline $\operatorname{cc} 8 \cdot 3$ & 20.2 & $\cdots$ & $\cdots$ & 37.9 & 46.7 & 52.6 & 83.6 & 12.2 & 47.4 & 8.9 & 11.1 & $\ldots$ & 8580 & 10750 & 12100 \\
\hline $\mathrm{CC} 8-4$ & 19.9 & $\cdots$ & $\cdots$ & 38.7 & 48.3 & 55.2 & 81.5 & 39.3 & 44.8 & 9.9 & 12.4 & $\because$ & 8250 & 10310 & 11770 \\
\hline DC1-1 & 14.8 & $\cdots$ & $\cdots$ & 37.0 & 43.5 & 48.7 & 39.0 & 46.7 & 51.3 & 9.2 & 10.8 & $\cdots$ & 9030 & 10600 & 11880 \\
\hline $\mathrm{DCl}-2$ & 15.0 & $\ldots$ & $\cdots$ & 35.4 & 41.7 & 51.8 & 33.0 & 38.8 & 48.2 & 16,6 & 18.5 & $\cdots$ & 8150 & 9580 & 11000 \\
\hline FM1-2 & 11.8 & $\ldots$ & $\cdots$ & 27.1 & 30.8 & 52.6 & 24.5 & 27.7 & 47.4 & 36.6 & 41.5 & $\therefore$ & 5790 & 6570 & 11230 \\
\hline FM1-4 & 13.8 & $\cdots$ & $\cdots$ & 31.7 & 36.7 & 52.8 & 28.2 & 32.7 & 47.1 & 26.3 & 30.6 & 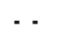 & 6890 & 7990 & 11500 \\
\hline FMI-7 & 13.4 & $\cdots$ & $\cdots$ & 36.1 & 41.7 & 50.8 & 35.7 & 41.2 & 48.7 & 14.8 & 17.1 & $\cdots$ & 8290 & 9580 & 11660 \\
\hline$F M 1-10$ & 13.6 & $\ldots$ & $\cdots$ & 33.2 & 38.4 & 53.3 & 29.1 & 33.7 & 46.7 & 24.1 & 27.9 & - & 7090 & 8210 & 11880 \\
\hline FM1-13 & 11.2 & - & $\cdots$ & 38.7 & 43.6 & 55.1 & 81.6 & 35.6 & 44.9 & 18.6 & 20.9 & $\cdots$ & 8650 & 9740 & 13320 \\
\hline FM2-1 & 18.3 & $\cdots$ & $\cdots$ & 40.6 & 49.7 & 57.9 & 29.6 & 36.2 & 42.1 & 11.5 & 14.1 & $\ldots$ & 7770 & 9510 & 11080 \\
\hline FM2-2 & 18.8 & $\cdots$ & $\ldots$ & 43.6 & 50.6 & 66.7 & 33.3 & 38.7 & 4.3 .3 & 9.2 & 10.7 & $\cdots$ & 8870 & 10300 & 11530 \\
\hline FM2-6 & 7.3 & $\cdots$ & $\ldots$ & 25.9 & 27.9 & 63.1 & 15.1 & 16.4 & 36.9 & 51.7 & 55.7 & $\cdots$ & 4570 & 4930 & 11130 \\
\hline $\mathrm{FrCl}-1$ & 13.8 & -- & $\cdots$ & 35.2 & 40.8 & 52.9 & 31.2 & 36.3 & 47.1 & 19.8 & 22.9 & $\therefore$ & 7780 & 9020 & 11710 \\
\hline $\mathrm{JC2}-2$ & 14.3 & $\cdots$ & $\cdots$ & 36.5 & 42.6 & 45.6 & 43.7 & 50.9 & 54.4 & 5.5 & 6.5 & $\cdots$ & 9680 & 11240 & 12010 \\
\hline JC3-1 & 14.9 & $\cdots$ & $\cdots$ & 40.4 & 47.4 & 67.9 & 29.4 & 34.6 & 42.1 & 16.3 & 18.0 & - & 7320 & 8590 & 10480 \\
\hline JC3.5 & 13.7 & $\cdots$ & $\cdots$ & 37.8 & 43.8 & 54.6 & 31.3 & 36.3 & 45.4 & 17.2 & 19.9 & $\cdots$ & 7840 & 9090 & 11340 \\
\hline PAl.5 & 15.9 & $\cdots$ & $\cdots$ & 38,6 & 45.9 & 54.6 & 32.1 & 38.2 & 45.4 & 13.4 & 15.9 & . & 8160 & 9700 & 11540 \\
\hline PA1-32 & 16.6 & $\cdots$ & $\cdots$ & 43.5 & 52.1 & 59.8 & 29.1 & 34.8 & 40.1 & 10.9 & 19.1 & $\cdots$ & 9050 & 10840 & 12470 \\
\hline $\mathrm{PAI}-34$ & 8.0 & $\ldots$ & . & 38.4 & 41.8 & 63.2 & 22.4 & 24.3 & 36.8 & 31.2 & 33.9 & $\cdots$ & 7360 & 8000 & 12110 \\
\hline PA 2-1 & 14.9 & $\cdots$ & $\cdots$ & 39.1 & 46.0 & 60.6 & 25.6 & 30.0 & 39.5 & 20.4 & 24.0 & -- & 7490 & 8780 & 11580 \\
\hline PA3-1 & 12.7 & $\cdots$ & $\cdots$ & 35.2 & 40.3 & 58.7 & 24.7 & 28.3 & 41.3 & 27.4 & 31.4 & $\cdots$ & 6640 & 7610 & 11080 \\
\hline РАЗ-9 & 15.6 & $\cdots$ & $\cdots$ & 35.8 & 42.4 & 56.4 & 27.6 & 32.7 & 43.6 & 21.0 & 24.9 & $\cdots$ & 7170 & 8500 & 11310 \\
\hline
\end{tabular}


Table B-14. Proximate analysis (cont.)

\begin{tabular}{|c|c|c|c|c|c|c|c|c|c|c|c|c|c|c|c|}
\hline \multirow[t]{2}{*}{ Sample } & \multicolumn{3}{|c|}{ Moisture (\%) } & \multicolumn{3}{|c|}{ Volatile matter $\{\%\}$} & \multicolumn{3}{|c|}{ Fixed carbon (\%) } & \multicolumn{3}{|c|}{$\operatorname{Ash}(\%)$} & \multicolumn{3}{|c|}{$\begin{array}{c}\text { Heating value } \\
(\text { Btu/lb) }\end{array}$} \\
\hline & $1^{2}$ & 2 & 3 & 1 & -2 & 3 & 1 & 2 & 3 & 1 & 2 & 3 & 1 & $\underline{2}$ & 3 \\
\hline $\mathrm{SC} 2-2$ & 16.0 & $\cdots$ & $\cdots$ & 41.2 & 49.1 & 53.3 & 36.8 & 42.6 & 46.5 & 7.0 & 8.3 & $\cdots$ & 8510 & 10130 & 11050 \\
\hline$S C 2-3$ & 15.6 & $\therefore$ & - & 39.4 & 46.7 & 50.3 & 38.9 & 46.1 & 49.7 & 6.1 & 7.2 & . & 9030 & 10690 & 11520 \\
\hline SC3-1 & 17.4 & - & $\cdots$ & 32.9 & 39.9 & 52.2 & 30.2 & 36.6 & 47.8 & 19.6 & 23.6 & $\cdots$ & 7580 & 8180 & 12010 \\
\hline $\mathrm{SC} 4-2$ & 16.3 & $\cdots$ & . & 40.6 & 48.5 & 53.9 & 34.8 & 41.5 & 46.1 & 8.3 & 10.0 & . & 8370 & 10000 & 11110 \\
\hline SC4-4 & 15.5 & $\cdots$ & $\cdots$ & 41.2 & 48.8 & 52.9 & 36.7 & 43.4 & 47.1 & 6.6 & 7.8 & $\cdots$ & 9010 & 10660 & 11550 \\
\hline $5 C 4-7$ & 18.1 & $\cdots$ & . & 98.8 & 47.4 & 49.0 & 40.3 & 49.2 & 51.0 & 2.8 & 3.4 & $\ldots$ & 9490 & 11580 & 11990 \\
\hline SC4-12 & 17.5 & $\cdots$ & $\therefore$ & 33.2 & 40.8 & 53.5 & 28.9 & 35.0 & 46.5 & 20.4 & 24.7 & $\cdots$ & 7500 & 9100 & 12080 \\
\hline SR1-2 & 14.7 & $\cdots$ & . & 31.2 & 36.6 & 49.6 & 31.8 & 37.2 & 50.4 & 22.9 & 26.2 & $\cdots$ & 7260 & 8520 & 11540 \\
\hline TRI-1 & 18.2 & $\ldots$ & . & 37.9 & 46.4 & 49.0 & 39.8 & 48.8 & 51.0 & 4.3 & 5.3 & . & 10960 & 13400 & 14150 \\
\hline WC1-3 & 15.2 & $\cdots$ & $\cdots$ & 36.8 & 41.6 & 45.9 & 41.6 & 49.1 & 54.1 & 7.9 & 9.3 & $\cdots$ & 9350 & 11020 & 12150 \\
\hline$W C 1-4$ & 14.2 & $\ldots$ & $\cdots$ & 31.5 & 36.7 & 56.1 & 24.7 & 28.8 & 43.9 & 29.6 & 34.6 & $\cdots$ & 6570 & 7660 & 11700 \\
\hline WC2-4 & 15,4 & $\cdots$ & $\cdots$ & 32.0 & 37.8 & 52.2 & 29.4 & 34.7 & 47.8 & 29.2 & 27.4 & $\cdots$ & 7370 & 8710 & 12010 \\
\hline WC2.9 & 13.8 & $\ldots$ & $\ldots$ & 29.9 & 34.6 & 50.3 & 29.6 & 34.1 & 49.7 & 27.2 & 31.3 & $\ldots$ & 9240 & 10670 & 15540 \\
\hline WC2-10 & 14.9 & $\cdots$ & . & 33.3 & 39,1 & 50.3 & 32.9 & 38.7 & 49.7 & 18.9 & 22.2 & $\cdots$ & 8030 & 9430 & 12120 \\
\hline WC2-1 4 & 15.0 & & $\ldots$ & 30.6 & 36.0 & 50.4 & 30.1 & 85.4 & 49.6 & 24.3 & 28.6 & . & 7180 & 8430 & 11800 \\
\hline
\end{tabular}


APPENDIX C

Geologic Columns with Sampling Locations 
BELUGA RIVER SEAMS

SITE: BR $\perp$

LI'RFOLOGIC DESCRTPTION

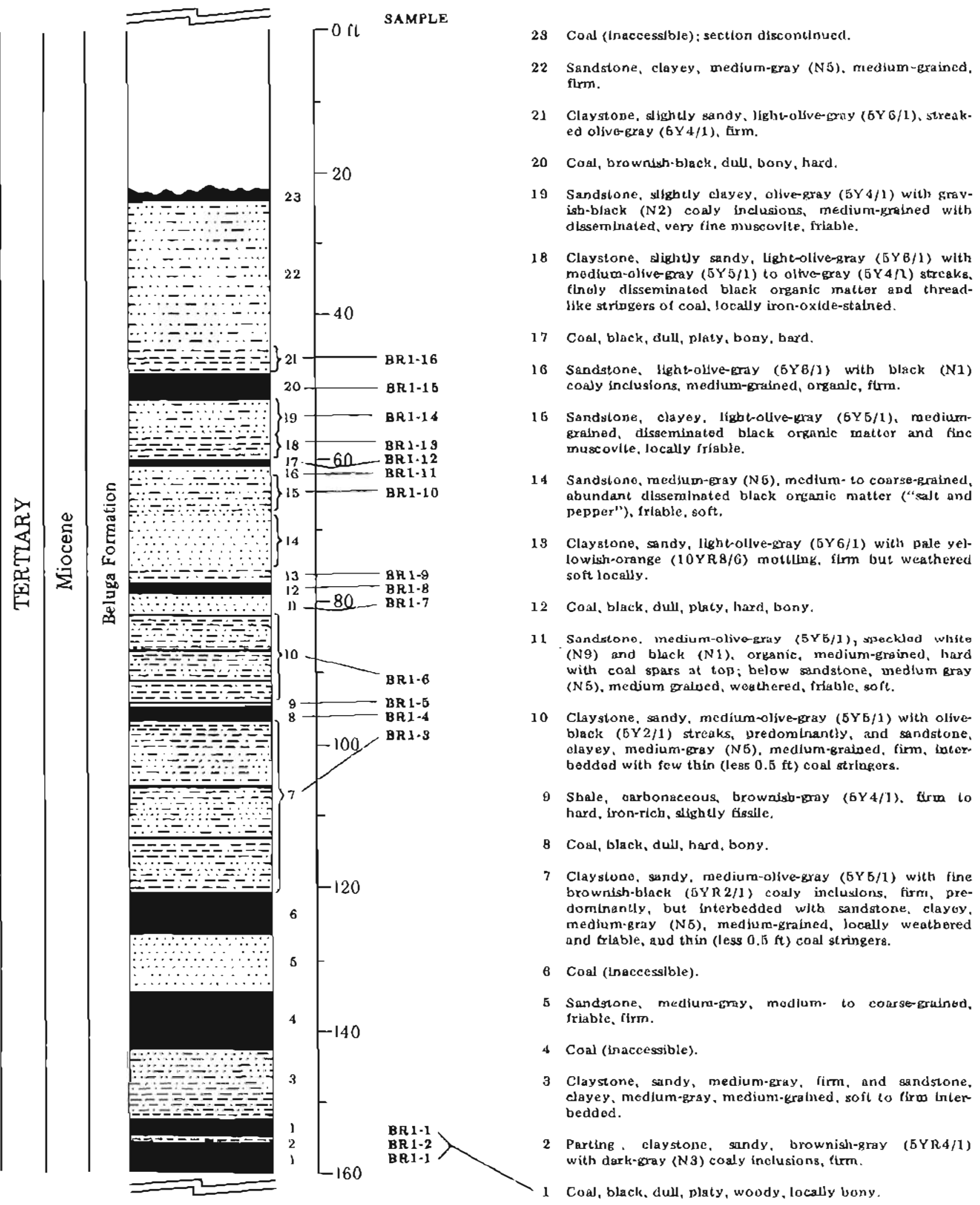


CANYON CREEK BEAM

SITE CnC6

LITHOLOGIC DESCRIP'CION

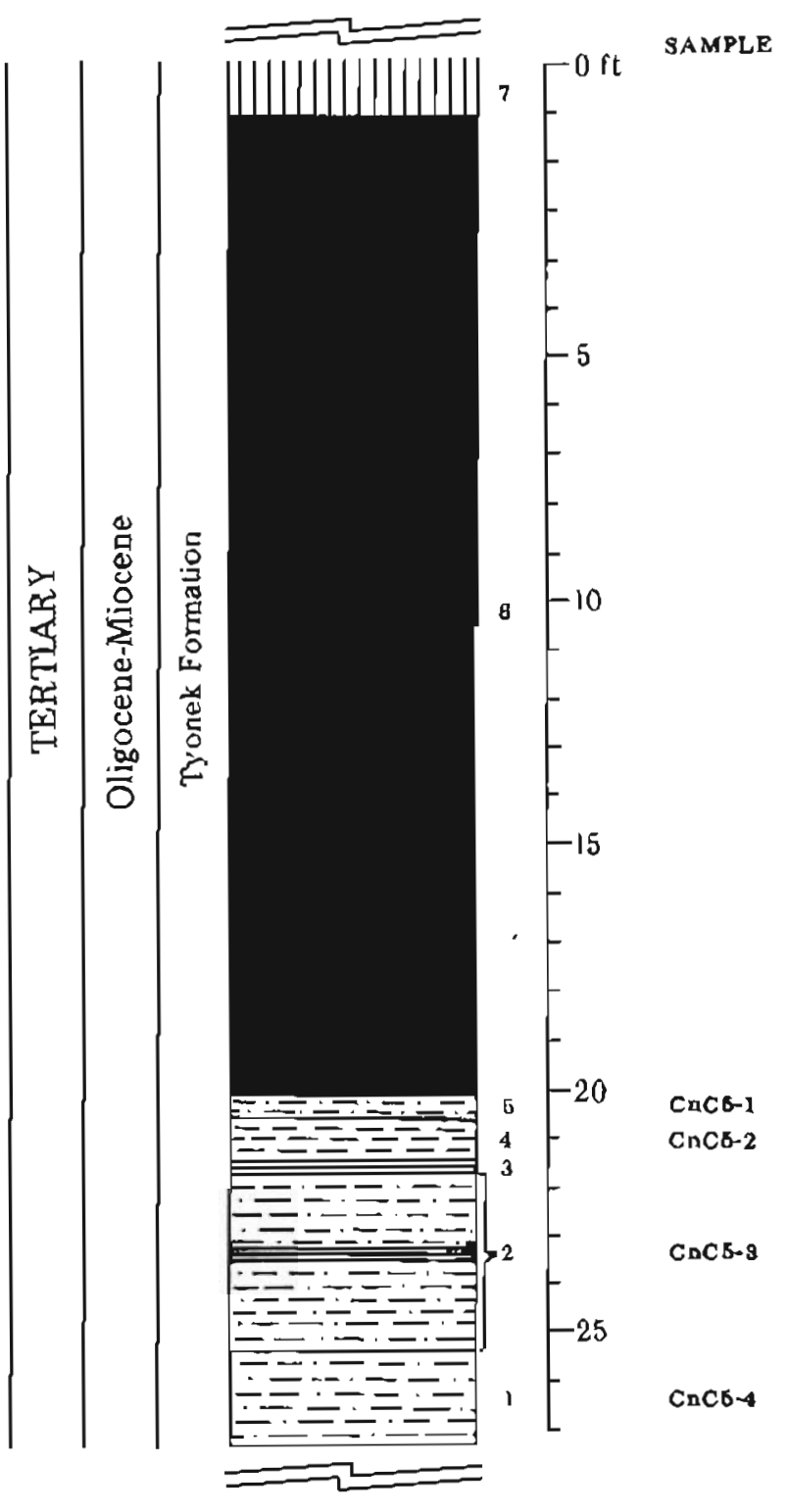

7 Roof covered and inacessable.

O Canyon Bed: Donj, black, dull, blooky with liw vliraln bands, haxd : locally platy and asby.

$$
\text { SEATROCK }
$$

b Claystone, sandy, ollve-black ( $5 Y / 1$ ), carbonaceous, firm.

4 Claystone, pinklah-gray (5YRB/1) with graylsh-black (N2) to black (N1) coaly inclusions, locally carbonaceous, rooled, weathered and soft.

3 Shale, carbonaceous, black (N1), thodle, higlaly wethered sot.

2 Claystone, slighly sandy, pinkish-gray (6YR8/1) with griylab-black (N2) coaly inclusions and bluck (N1) dis seminated oreanic matter, flrm: 0.2 ft bind of shale, carbonaceous, black (N1), fissllo, highly weathered and soft in center of unit.

1 Claystone, sliphtly sandy, plnkigh-eray (5YR8/1) with black (Ni) coaly inclugions and local dark-yollowlshorange (10YRB/6) mottlos. 
CANYON CREEK SEAM

SITE CnC?

LITHOLOGIC DESCRIPTION

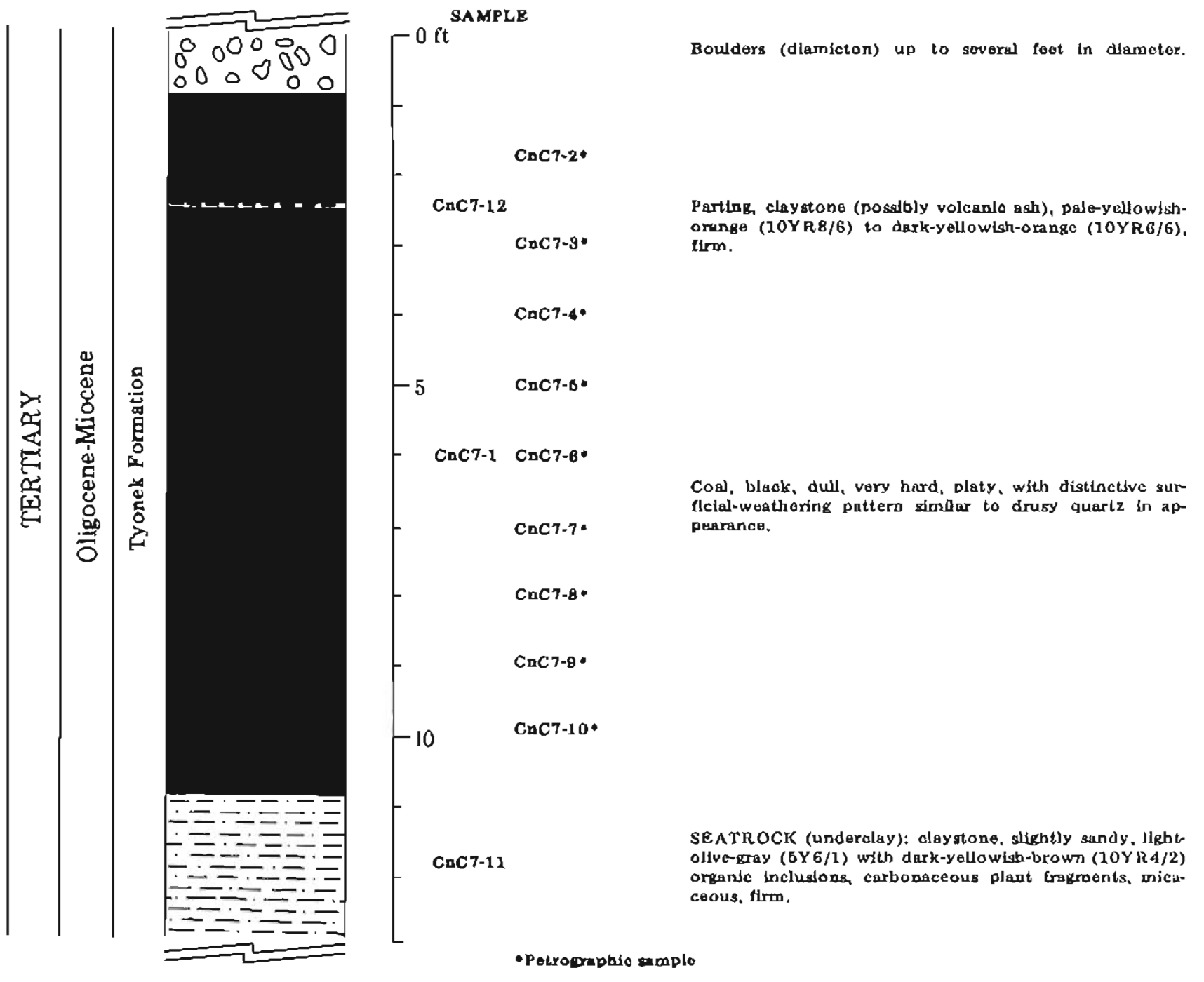


ANYON CREEK SEAM

SITE CnCB

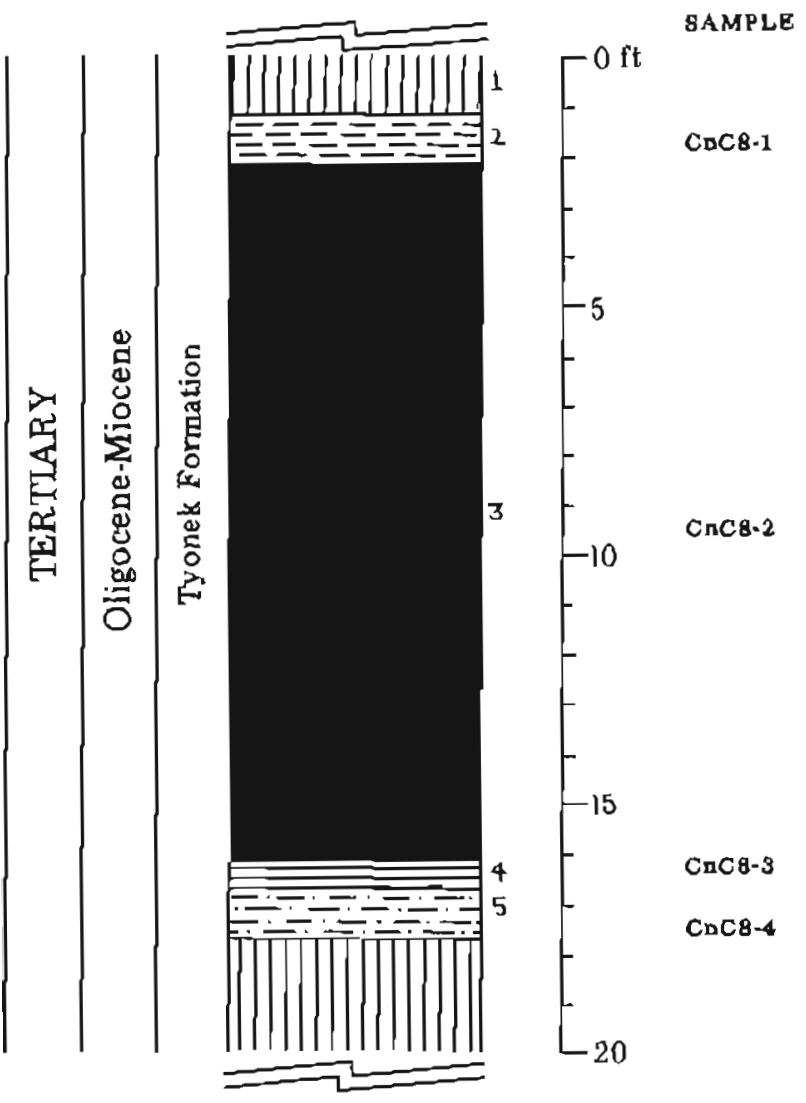

LITHOLOGIC DESCRIPTION

1 Covered intervil directly above roof but includes bouders (diamicton) to several feot is diameter toward top of section.

LRool: claystone, alghty sundy, ollvo-gray (5Y/11), carbonacbous, soft

${ }^{3}$ Coal, black, dul, blooky, hard, quallty of coul detertorates significartly to basal $2-8 \mathrm{ft}$.

SEATROCK

4 shale, carbonaceous, brownish-black (5YR2/1), soft, smutty.

S Claystone, gindy, Ilebt-ollve-gray (5Y6/1), alleht)y carbonaceous, espedally toward Lop. mlcacoous, sote to flrm. 


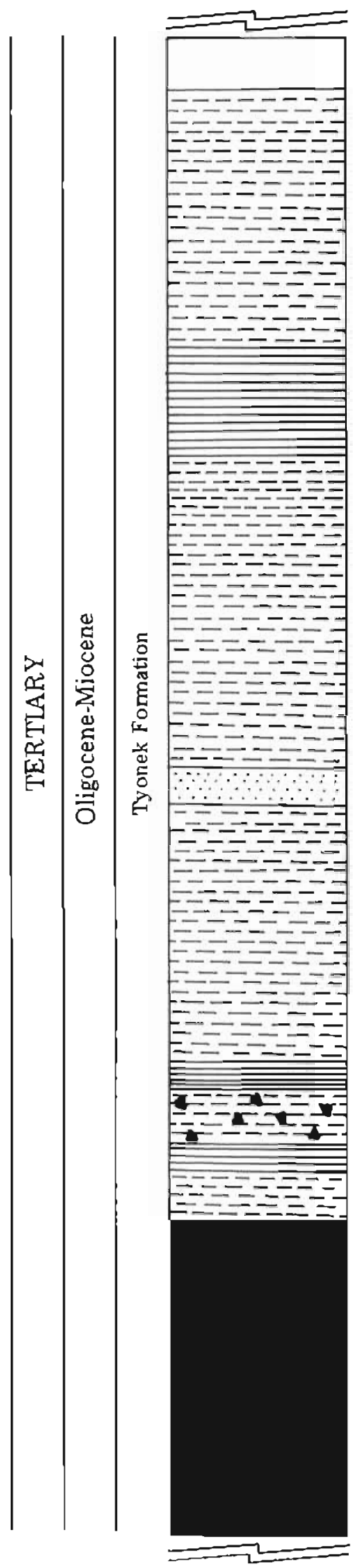

8AMPLE

Surbiclal cover: prodominantly a brown sandy loam.

Claystone, olive-blick (5Y2/1) lo brownids pray

(5YR4/1), carbonacoous, brakes with blocky coneholdal tracture, Itrm, Jocally bas palevellowisb-ornano (1OYRB/6) to Light-brown (6YRE/6) goethite staining slong weatbered gurfaces and tracturo plines.

Shale, carbonacoous, brownisb-black (5YR2/1) to ollve black (5Y2/1) to gray ish-black (N2), fino to soft, locally flasilo with thin Interbeddod Jenses (less 1 in.) of sandstone, medium-gray (N5), coarse-urabined, and coal (aporoximately 1 lo. thick), bluck, bony, phity, soft und weathered.

Clayglone, altghtly sandy 20 sandy, modium-gray (N5), mesavo, tim, blocky concboldal fracturo and wbundant iron-oxide staining along gacturo planes and weathering gurfaces.

Sandstone, Ifaht-olive-gray (GYB/1) to medlum-ollve-pray (6Y6/1), coarse-gralned, vary hard, calcareous, with abuadint planteloat posgls, paloyellowish-arange (10YR8/6) iron-oxidt stuining along central (2 In. thick) bend.

Claystone, alive-black (5Y2/1). masgivo, 1lym, wilh sbundunt black, carbonsceous, fossil-leaf llms, localy with moderate-red (5R4/6) to dusky-rod (5R 3/4) hemotieic oxidation alainlag.

1 Shale, black (N1) to brownish-b)inck (5YR 2/1), sitoht) oarbonaceous, flselle. soth to lirm, locally highly weathered.

2 Claystone, moderace-brown (5YR9/4) with black (N1) cody lnclusions, solt 10 firm, breaks with concholdal tracture. roundes umontio on bemotite nodules to 2 lo. diameter, thin streaks and contorted laminae of black carboraccous shale.

CG3-11*

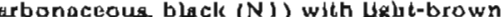
(6YR6/6)-weathering stains, llssile, soft.

4 Claystono, ollve-bay ( $5 Y \cdot 1 / 1)$ co olive-b)ack (5Y2/1), furn lo soft. with blacky fyacture pallem.

Capos Searn: coal, black, dull, firm to hard, locally witb thin (less 3 in.) vitrain bands, surfaces and tractures covered wlib abundanl tron-oxide and sulfato stains, local siderile.

$\cos -19 \cdot$ 

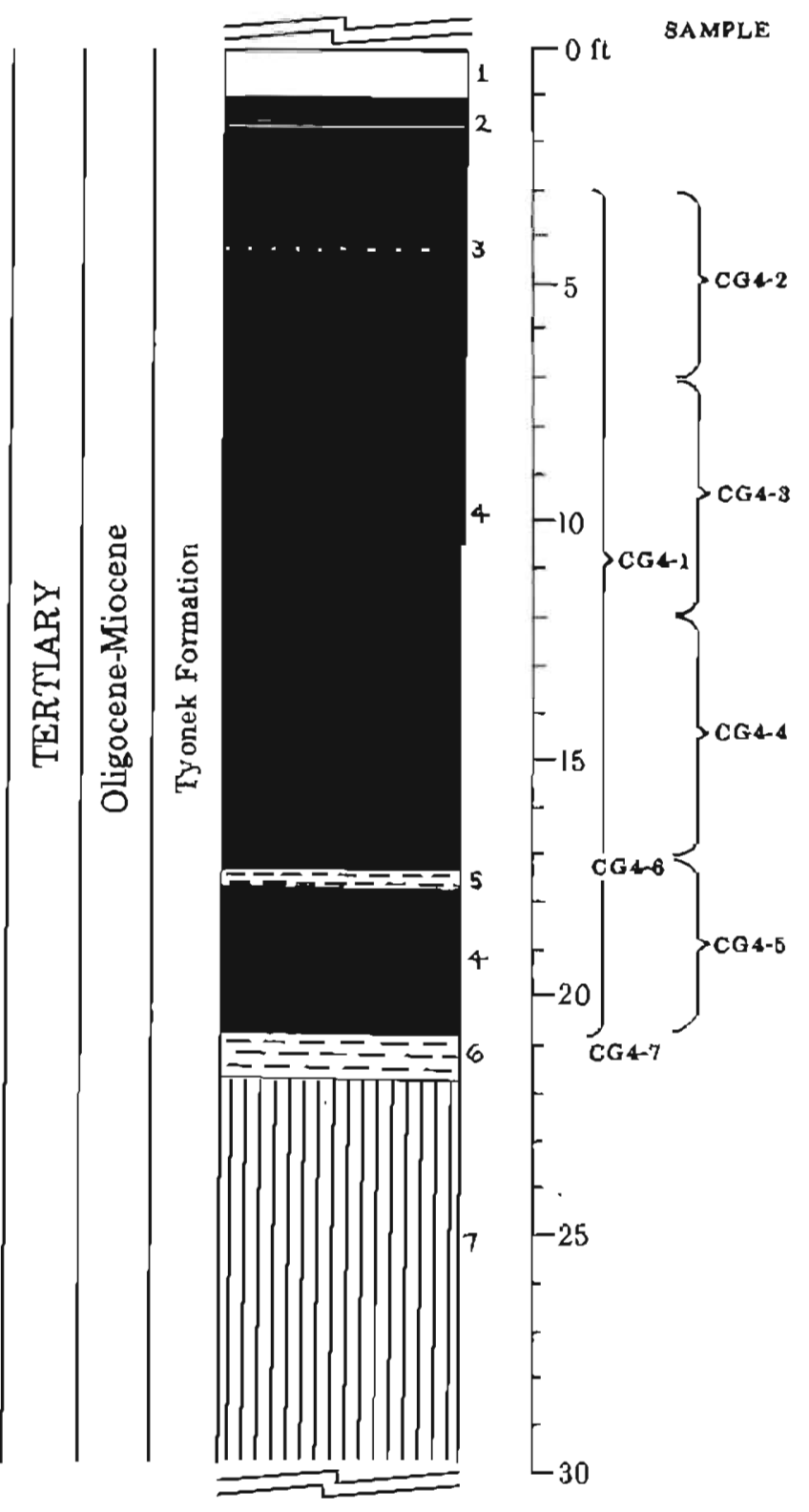

'Surdetal aover; unconsolidated lightbrown sand and
sandy loam.
2 Coal (top 2 (t), black, soft, higbly wealhered, and shale, 2 Coal (top 2 t), black, sofl, higbly wealhered, and shale,
carbonacoous, black (N1), fisslle, brm. CG4-9* CG49. CG4-10* $\cos 411^{*}$ CG-12*

$\operatorname{cG4} 19^{*}$

${ }^{3}$ Partine, claystone, dark-kray, carbonacoous, soth.

CG4-14* CG4-15*

4 Capps Seum; coal, black, predom Inantly dull and blocky but locally bony and platy with lncreasing vitrain bands toward basal portion.

$\cos 46^{\circ}$

5 Parting: claystono (possbly voleanic ash), ligh -brownlshgray (6YRG/1), tirm.

SEATROCK (underclay)

6 Claystoue, medlum-olive-gxay (5Y $5 / 1$ ) with sraylah-black (N2) carbonaceous inalublons, locally glightly Hssle, soH to flrm.

7 Section down to levol of Capps Creok largely covered with tajus and regolity but prodominanely sindatone, medium-gray (NG), medlum-gráned, triable bit Frm. and claystone, sandy, raodlum-gray (NE). soft to firm. breaks with concholdal tracture. 

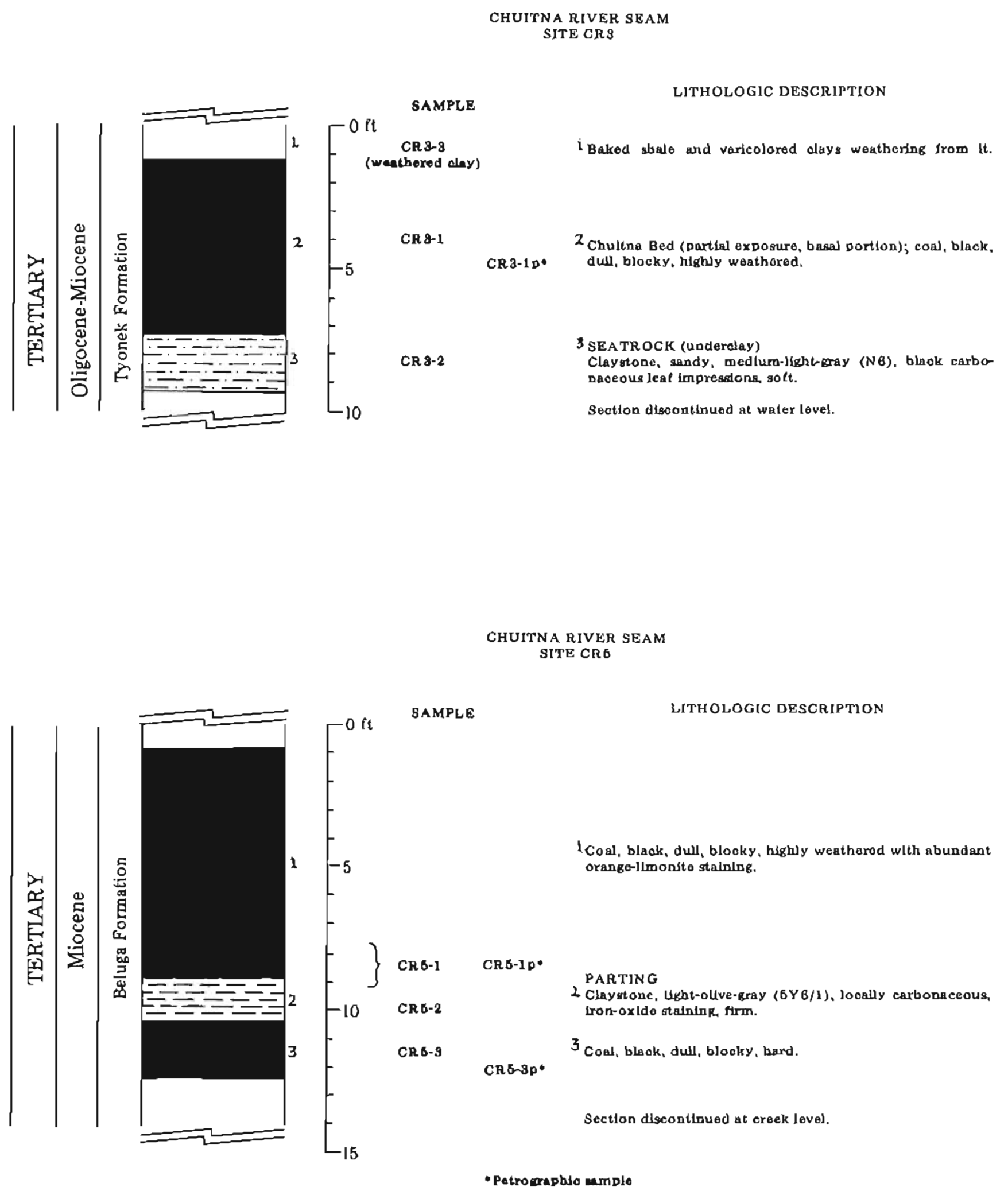
CHUITNA RIVER SEAM

SITE CRO

LITHOLOGIC DESCRIPTION

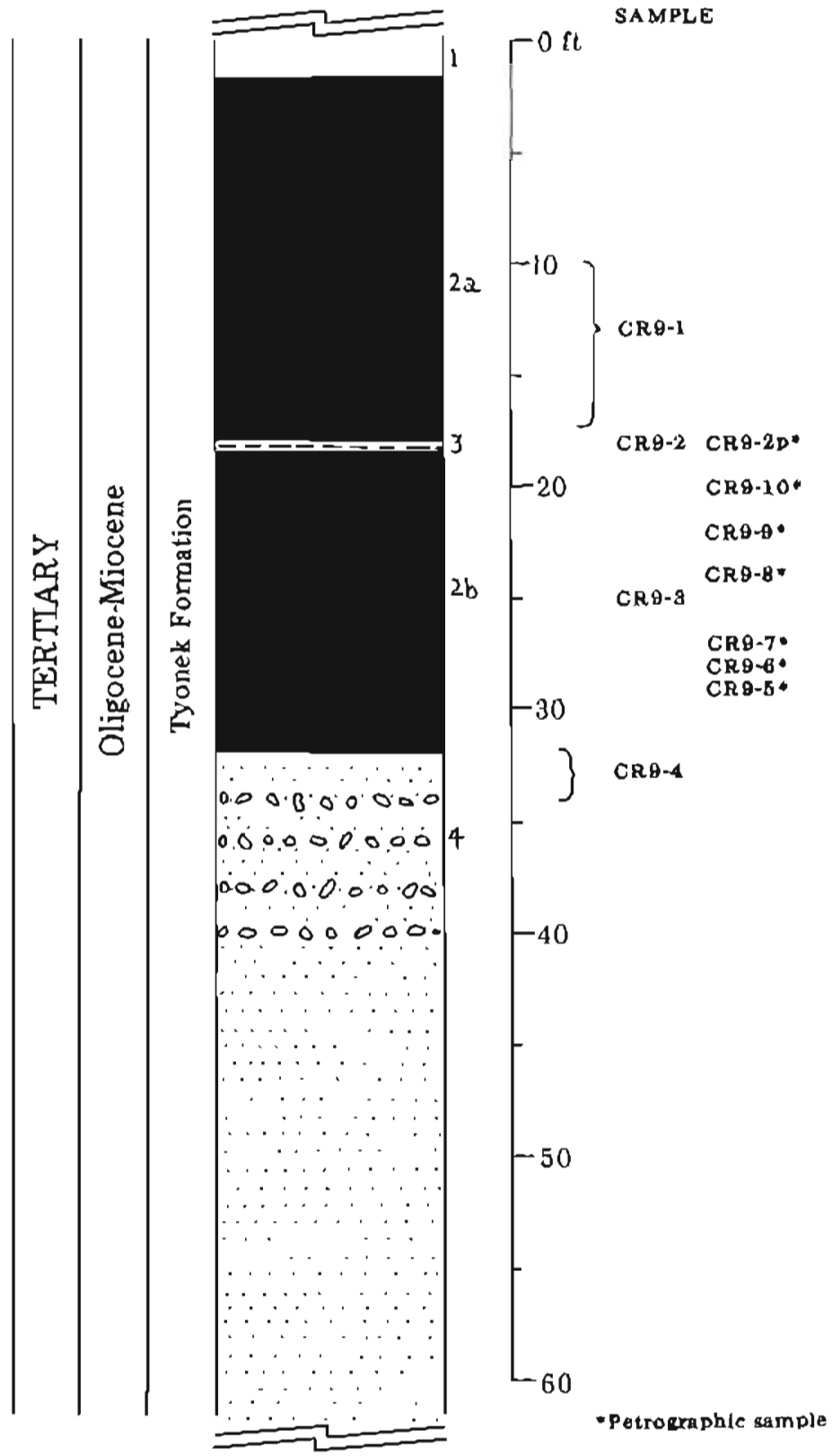

\footnotetext{
I roor of coal Inaccesstble.
}

2.2 Chuitna Bed: coal, black, hard, platy, clull, locally bony.

3 Parting (posslbly volcanic nah); claystone, gilty, olve b) nok (EY $2 / 1)$, weathers to graylsh-rod (10R4/2). $\mathrm{Hrm}$. breaks witb conchoidal fracture.

26 Coal velow parting predomlrantiy dull and blocky, ash contert appears signifleantly less than in upper portion: local mlnor pyrite and weathored-sulfate costings.

4 SEATFOCK

Sandstone, Hgbt-ollve-gray (5Y6/1) to pinkesh-gray (GYRB/t), medium-gralsod, relatively clean, predominantly quartiz witls disscminated biack organic malter, subrounded to angular grains, frluble, weatherud. soft. Minor (neax 0.6 it) partings of quartz-pobble conglomarate and conglomeratic sandatone loward top of section bonenth coef bed. 
CHUITNA RIVER SEAM SITE CR 10

LITHOLOGIC DESCRIPTION
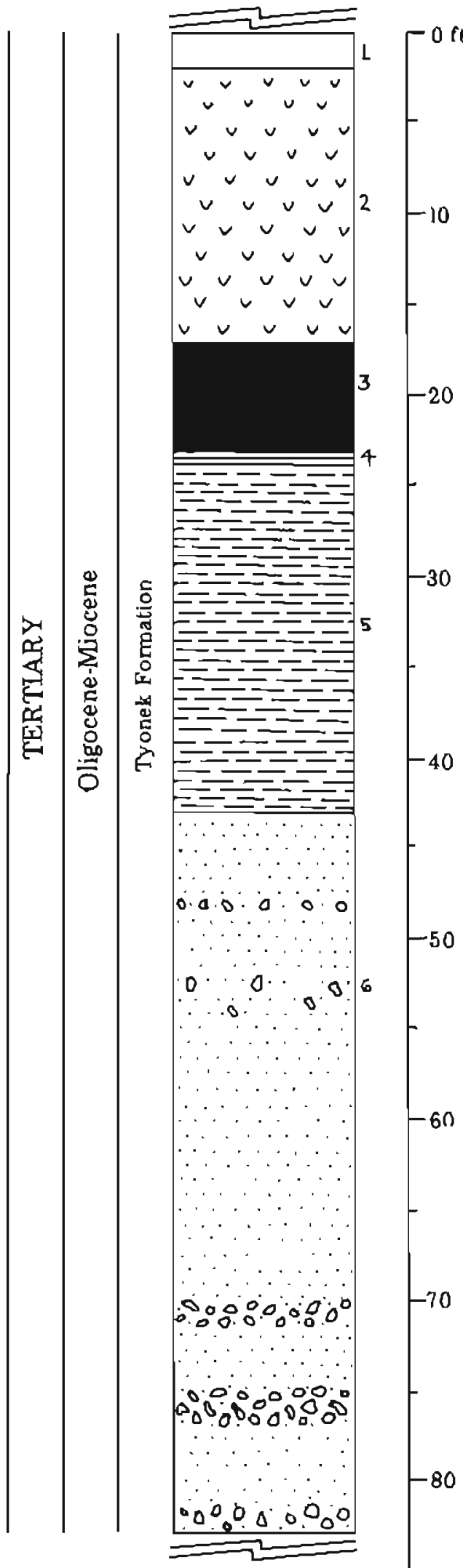

1 Surtlclal cover; brawn sandy lonm, sand, and gravel

2 Bum (obinker. "red dof." scoria, porcellanite).

CR10-7*

CR10-6*

CR10-1 CR10-5*

CR10-4*

CR10-3

CH $10-2$

30

40

0

60

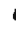

- Petracraphic enmple

I Claystone, durk-pray (N3), carbonadeous, goft, locally weatbered with leht-brown (5YR6/6)-limonlte stalndng.

6 Sandstone, medlumigray (N5), medium- to coarge-gralned, loculy conglomeratio witb interbedded quartipgeblecondonemte bands, ospecially coward the baal portion of outcrop and light-brown (5YR5/6)-Iron-oxide stajoing

3 Cod, predoroloantly dull and blocky with thin (husg 2 in.) vitrain bands and bony layers (to 0.5 lt), hard.

4 Sbale, carbonaceoug, olve-gray (6Y $4 / 1$ ) with light-brown (5YR6/6)-oxidation stadring, firm.

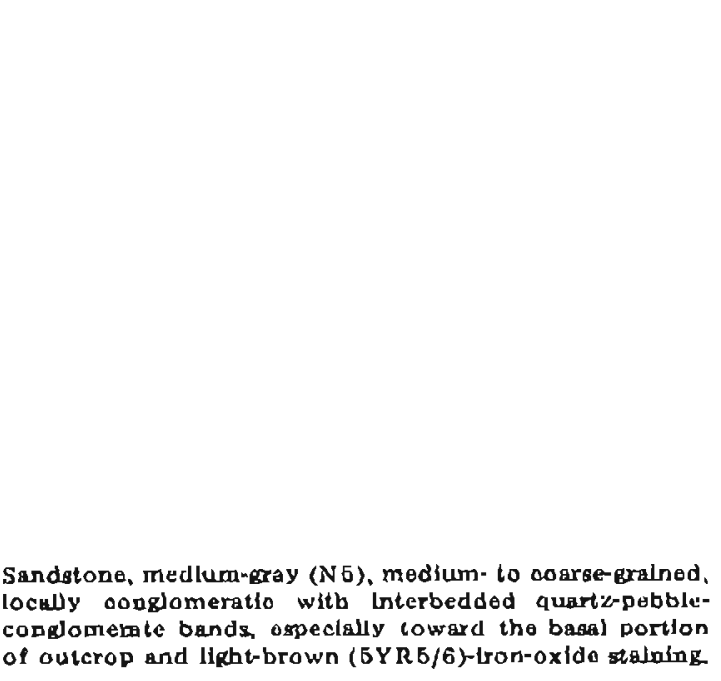




\section{FAIRVIEW MOUNTAIN SEAMS}

SITE FMI

Sheet I of 7

LITHOLOGIC DESCRIPTION

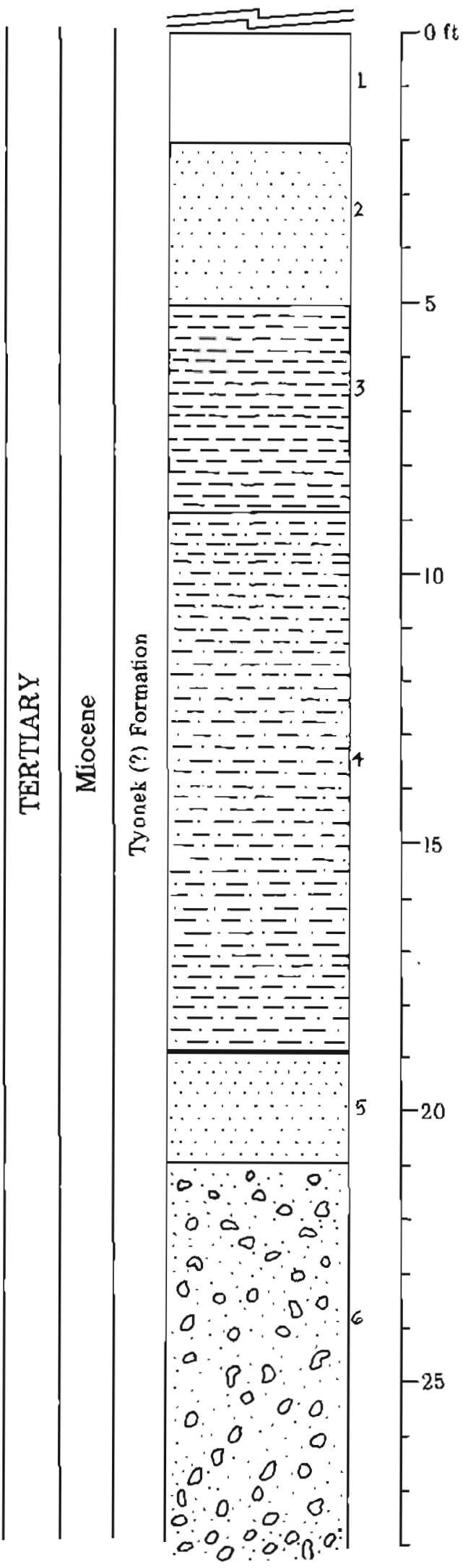

I Surficial cover; loam. sand, brown, disseminated blackorqunle matler, soft, rooted.

2 Sand, yellowloh-gray, medium-gralnod, sl tehtly clayey, soft, yellow- to arange-iron-oxlde motding, raye extremely fine disseminated muscovito.

3 Claystone, light-gray, soft, with abundant yollowalronoxide stainlar.

4 Claystone, gandy, medium-aray, flno disseminated muscovite and black organic matter, firm; th coal. black, dull, very hard formine baso.

${ }^{5}$ Sapd, yollowigh-gray, coarse-rrained, locally contains dis $80 \mathrm{~m}$ inated organsc ahatter and abundant threadllke stringers of black carbonaceous miterial, weathered, loosc.

6 Conplomerate, petroralctle, llghe to medium-garay; sand matrlx, coarse-gralned, angular bagments. poorly cemented to loose, predoulgantly quariz and chert: "Rrisyel" mostly in size rango less 0.5 ft and includes varlous Ifneous Ithologles, coal gravels, and cobbles: interspersed withln unit wre thin (less 2 in.) atringers and pockels of clay, Hight- to medlum-gray, soft, plastle. Thin coal stringer (less $1 \mathrm{in.}$ ) at base of conglomerate. 
Sheet 2 of 7

SAMPLE

LITHOLOGIC DESCRIPTION

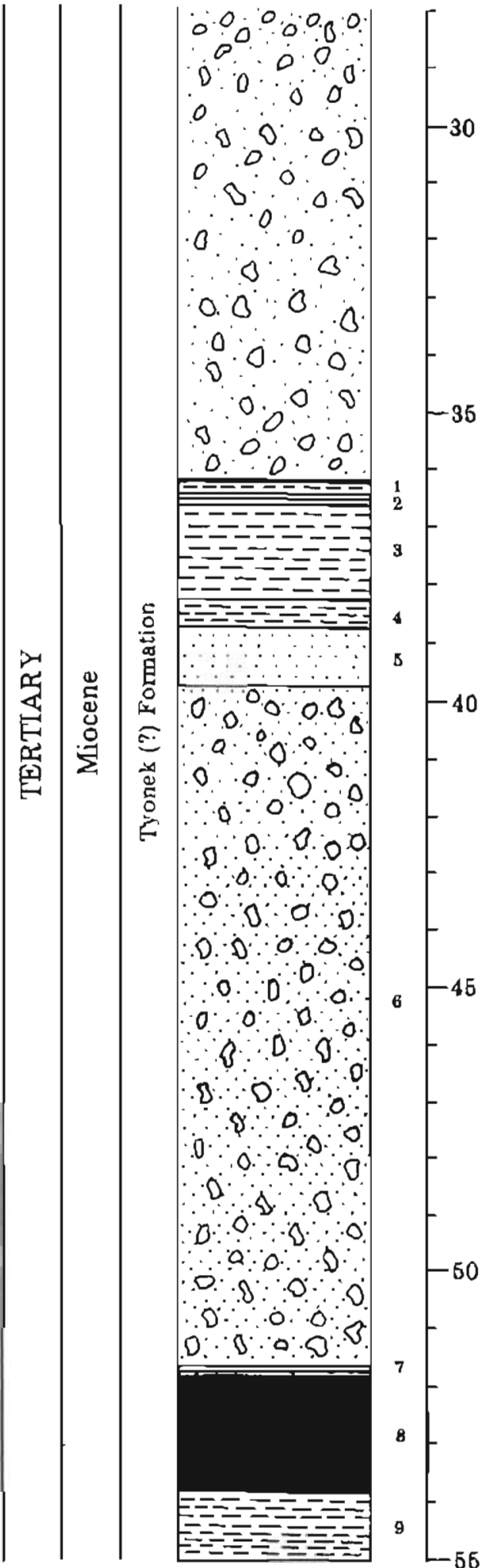

FM1-1 FM1-2a

FM1-2 FM1-2b: FM1 $-20^{\circ}$

FM1-3
) Claystone, durk-gray, glikhtly sundy, oarbonecoous, firm.

2 Shale, carbonaceous, black, Ilasile, sofe to firm, weath ored.

3 Clnygtone, modium-brownisli-gray, sllehtly oarbonaceous and sandy, flnm.

4 Claystane, medlum-gray, very sandy, firm.

6 Sand, modium-gray, medium- to coarse-grainod with ebundant limonitic and hemalitle stalaing and bleck ooaly stringors and bands.

6 Conglomeraco, Detromiatic (as above) but with abundaot cosl cobbles and gravol instugions: few graphita nodules 100.5 it diameter nerr base directly mbove coal; also contains lew clean orhoquartzite-sandstone cobbles.

7 Shale, carbonaceous, black (N1), flsslle, firm, woathored with abundant iron-oxlde staining.

F Seam

8 Coal, black, dull, platy, ashy, wentbered, poorquality.

9 Partings, claygtone, ollve-black (6Y 2/1), carbonaccous slently sindy. firm, tion (less 2 in.) cond bed in basal portion. 
FAIRVIEW MOUNTAIN SEAMS

SITE FM1

Sheet 3 of 7

SAMPLE

LITHOLOGIC DESCRIPTION
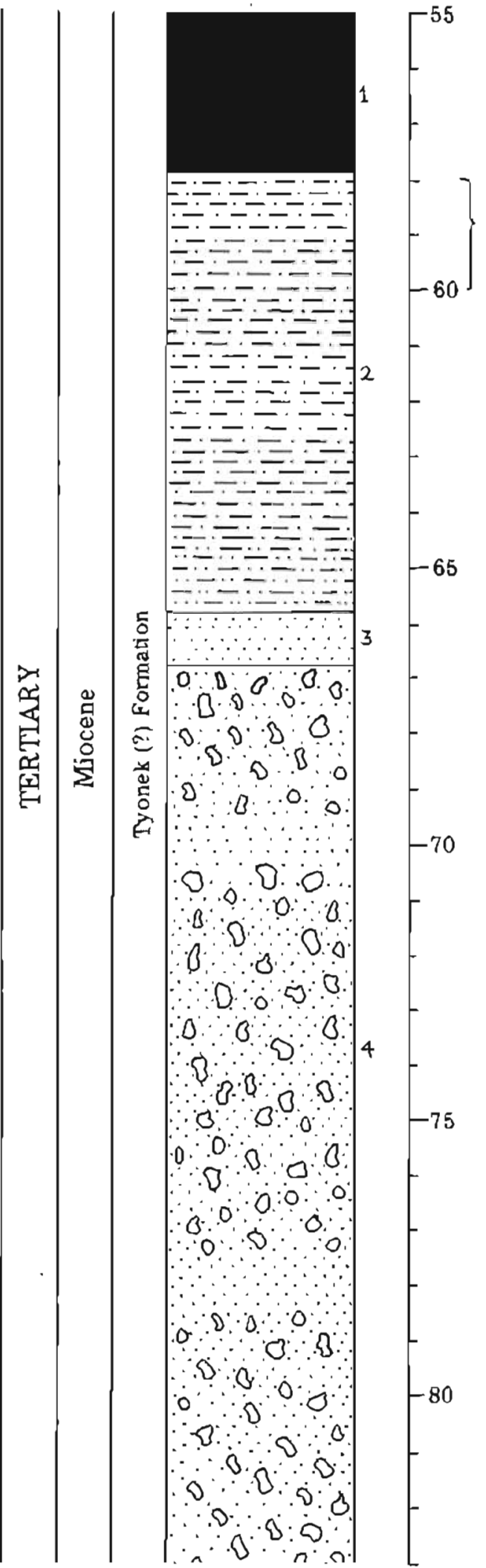

FM1-4

FM1-6

SEATROCK (underclay)

2 Claystono, sandy, medlum-llght (N 6 )-pxay, flrm, limonlte surface stains, breaks with ooncholdal dracture; bocomes more sandy toward basgl portlon wleb lew intergpersed sand lenses (less 1 ln.), llebt to medlum-gray, madluragrained, micaceous, loadly limonite-stained.

Con black, dull, platy, bony, poor qualley with thin ham tree of claystone, sandy, medlum-gray, sote and shale, carbonaceous, black. fisile, soft, Incercalated for top $2 \mathrm{ft}$ : lowor 0.5 ft dull, blocky, lsard conl.

5 gand, yellowish-gray, fine- to medium-grained, sott, loose with dlsembnated fine black organlc matter and muscovite; ndso smutty coal stringers (around $0.6 \mathrm{in}$.) locally.

\footnotetext{
4 Conglomeralo, Detromlatic pebblo-cobblo, with coersegralred, poorly lithiljed sand matrix; pobbles and cobbles prodominantly 2 in. co loss than 0.5 ft of vartous lgneous Uthologies (including granjte), abundane coal, quartz. chert and olean orthoquartzlte sundstone: pebbly andstono lenges to 1 ft thick locally throughout th ts section.
}

- Petrocraphic anuple 
FAIRVIEW MOUNTAIN BEAMS

SITE FMI

Sheet 4 of 7

LITHOLOGIC DESCRIPTION

\footnotetext{
1 Shale, carbonaceous, black (N1) with liaht-brown (5YR5/6) weathorlng stalns, slaslle, tirm.
}

E seam

FM1- T

FMI-7at

ond top 2 ft, black, dull, platy portlon dull, blocky, bony, hurd.

FM1-7b'

SEATROCK (undorclay)

3 Claymono, olluegray (GY 4/1) wleh bluck (NJ) coaly inolustons and locnl light-brown (GYRE/6) mottling, firm. broaks with oonoholdal friature.

4 Sandstone, modium-gray, flne-grained, frable. slightly clayoy, with fine dissominuted muscovite and black organie fragments.
5 Sand, medlum-gray, medium-grainod, looge, soft with desomlartod, extremely the muscovite and blaok organde malter, locally ilmonlte-stalised.

- Petrocraphic enmple 


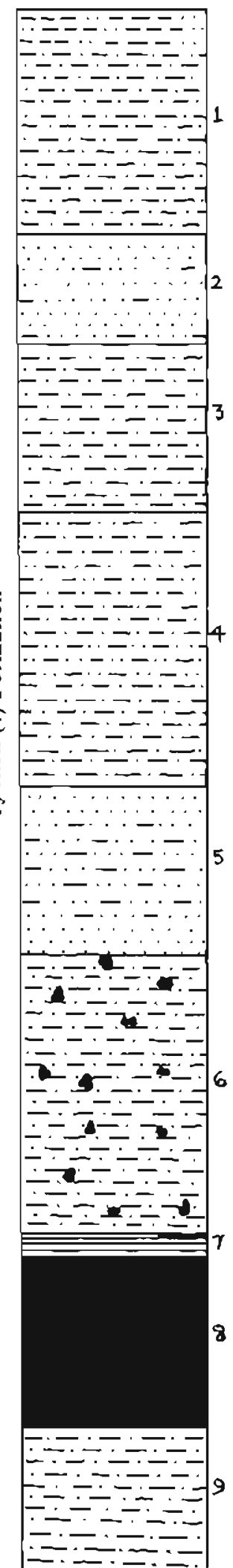
3 Claystone, sandy, medium-graylah-brown, flrm, local
jron-oxide stalning.

Sand, Ught- to medium-gray, flace to medjum-grained slightly clayey. soft, with disseminatod fine muscovito flakes and black organic matter.

1 Claystone, sondy to vary sandy, medlum-gray, firm with abundant Jumonite stainlag.

${ }^{4}$ Claystone, very sandy, Likgt-gray, firm.

5

Sandstone, clayey, light-kray, modlum-graloen, friablo soft, with the dissemiseted black organle matter and cosly streaks.

GClaystone, sandy, lighc-gray, firm, with weathered tronstone nodules to $2 \mathrm{in}$. dlamoter.

FM1-日

7 Shale, carbonaceous, dark-gray (N3) to black (N1), dayey, Ilsalle, soft.

FM1-10a

FM1-10b. $\quad$ D Seam

FML100*

SEATROCK (Undorclay)

9 Claystore, sandy, alive-pray (5Y4/1) with graylsh-black (N2)-thruadluke stringery, firm, breaks with concholdal fracture, locally limonito-stained.

- Petrographle semole 
FAIRVIEW MOUNTAIN SEAMS

SITE FMI

Sheet 6 of 7

SAMPLE

LITHOLOGIC DESCRIPTION

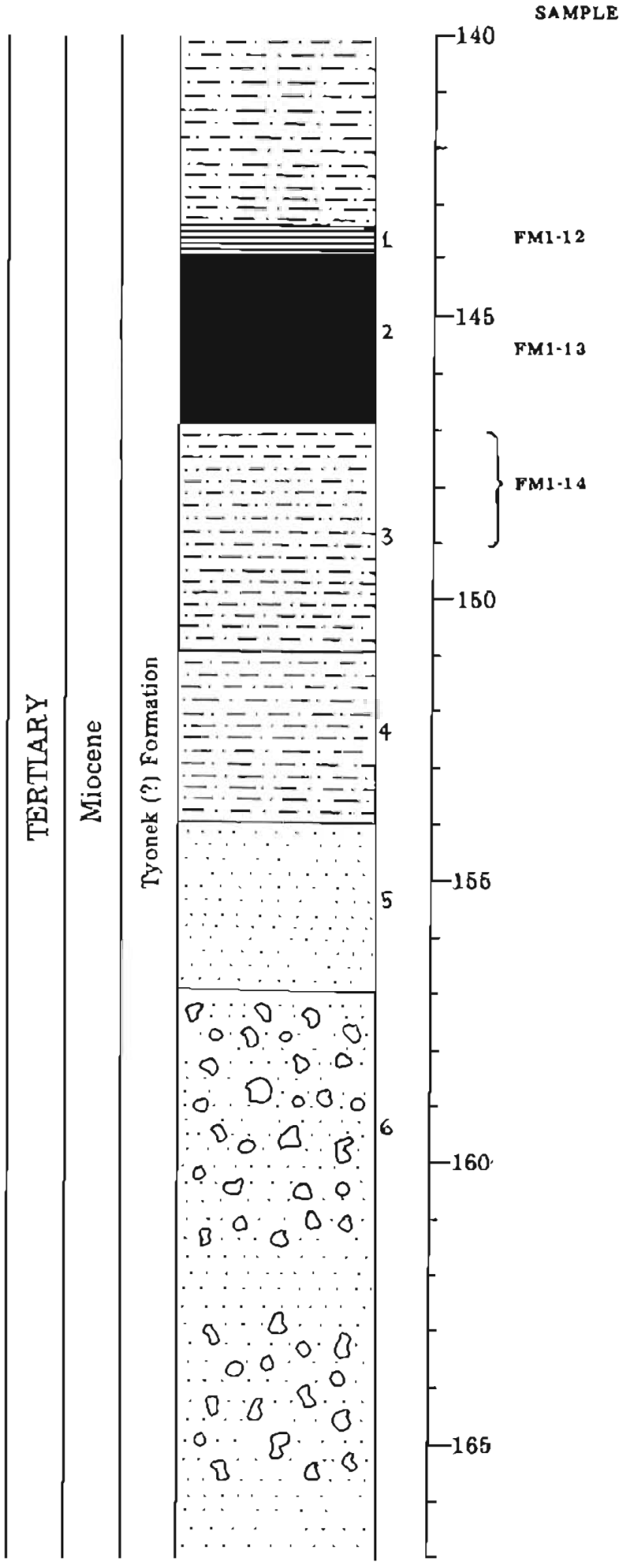

ROOF

1 Shale, curbonhceous, brownlgh-black (JYR2/1), fissllo, weathered, sofe.

C Seam

2 Coal, black, duld, bard, blocky at wop to bony and platy at basa porkion

SEATROCK (underday)

3 Claystone, vory sandy. liebt-ollive-pray (5Y6/1), thrm.

4 Claystone, sandy, modium-eray, lirm, with very tine dis sominated muscovitu.

5 Sand, medlum-kory, very coarse-gralned, apkllar to sub angular grains, dlssemlnatod black fine cual fragmenta, friable, looge, weathered.

F. Conglomerate, petromictlc, pebble-oobble (including cad); and antrix, vary coarse-gralned, poorly lithitled with the dlssemlnated coal tramments; local coarsearalned pebbly sand layerg up to 1 ft thick. 
FAIRVIEW MOUNTAIN SEAMS

SITE FMI

Sheet 7 of 7

LITHOLOGIC DESCRIPTION

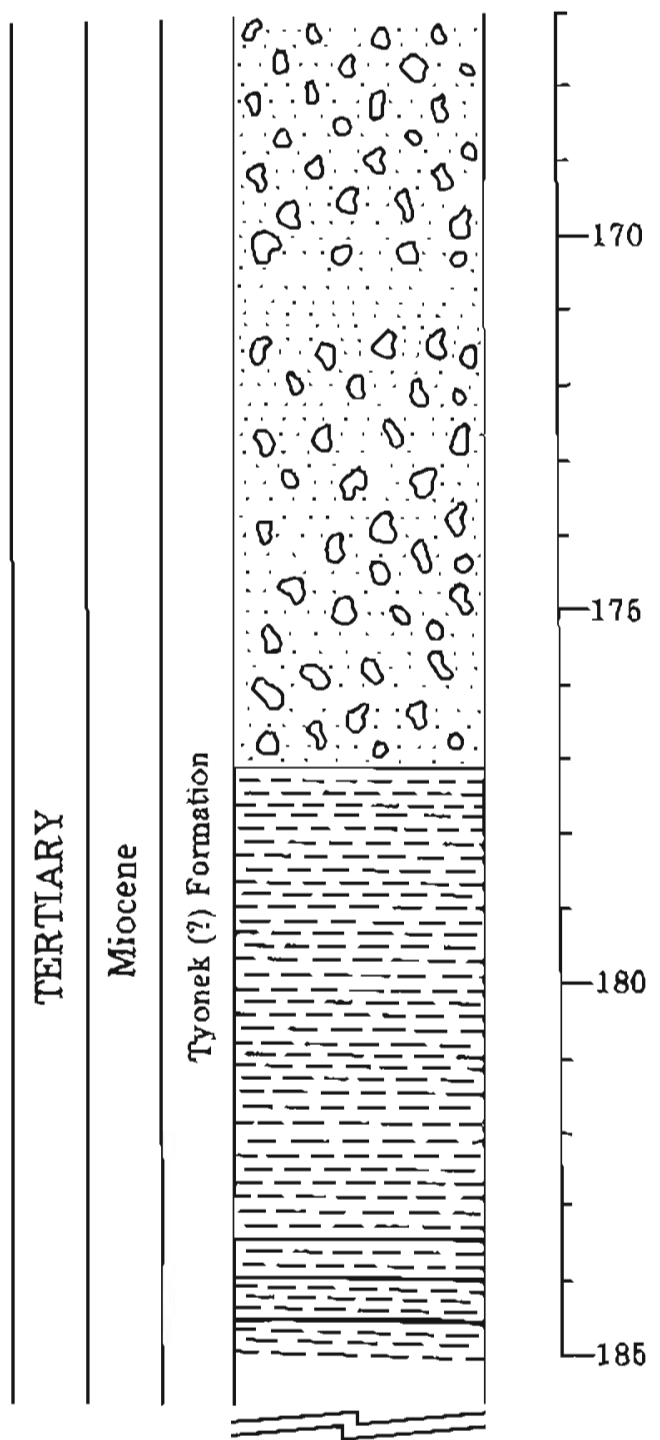

Claystone, medium-gray but grades to derk-gray and car bonacuous In basal portlon, soll to flno: pockets and stringors of ooal near bottom.

Saction discontinued but remalning section includes two poorly exposed and hlehly woathared cool seums (A and $B$ ); $\sec F M 2$. 


\section{FAIRVIEW MOUNTAIN SEAMS \\ SITE FM 2}

LITHOLOGIC DESCRIPTION

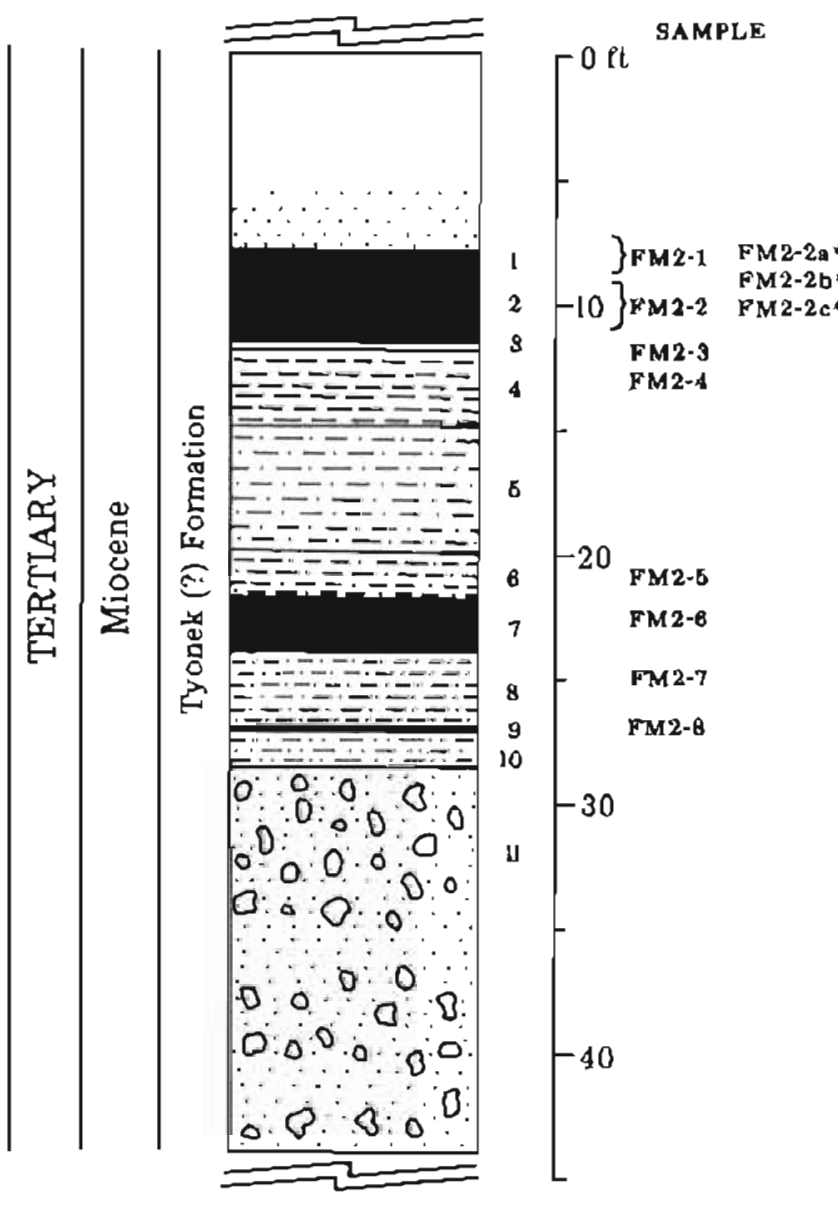

Surfloial cover pxodominantly a sandy loam yrading to sand at bast.

B Seam

1 \& 2 CoAl. Lop $0.5 \mathrm{ft}$ black, very soll, smully; botlom $9 \mathrm{ft}$ very bard and bony, bretks blooky and locally whth concboldal traclure.

8 Shale, aarbonacoous, brown, black (5Y2/1), clnyay, sot.

4 Claystone, olve-gray (6Y4/1) with moderate-brown (EYR4/A) plant-lragment isolusions, filehtly sllty. soft to flum.

6 Claystone, sandy, Wpht-gray, sol, with vory bae dist semlnated muscovite.

6 Claystono, medlum-gray (N5) with bluok (NY) Inclustons and dark-yellowlsh-orango (10YR6/6) motulng, sllghtly sandy and carbonacuous, firm.

A Seam

7 Coul, blnck to brownlsb-black, llendtio toward base, noor quallty: thin (less 1 in.) partlngs of daystone. brown, firm, and shale, curbonaceous, black, fissils, firm, toward LOP.

B Claystone, sundy, ollvogray (5Y4/1) with gruylah-brown (GYR3/2) and Blacklsh-red ( $5 R 2 / 2$ ) plant-fragmont inciusions, dissominated extremely flse muscoulte, tirm.

Q Cod stringer, black, bard, woody.

10 Clnystone, vory sandy, medium-gray (N 5), exlmemely the diseminaled muscovile, flrm.

11 Conglomerate, potromlotio, pebble-cobble, pebbles, erav ely, and cobbles predomlnantly Jess than 3 in. In dia. moter conslating of quartz, chert, orthoquartilts sand-

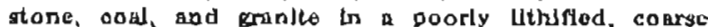
Braíned, sand matrix; nlso includes pobbly, coarsembrainedsand intervalg to several feut thick, yellowlsh-gray, angular to subangular with dissemlnated black organic matter.

Section described down to level of Cottouwood Creek.

- Potromephle rample 
JOHNSON CREEK SEAM

SITE JC2

LITHOLOGIC DESCRIPTION

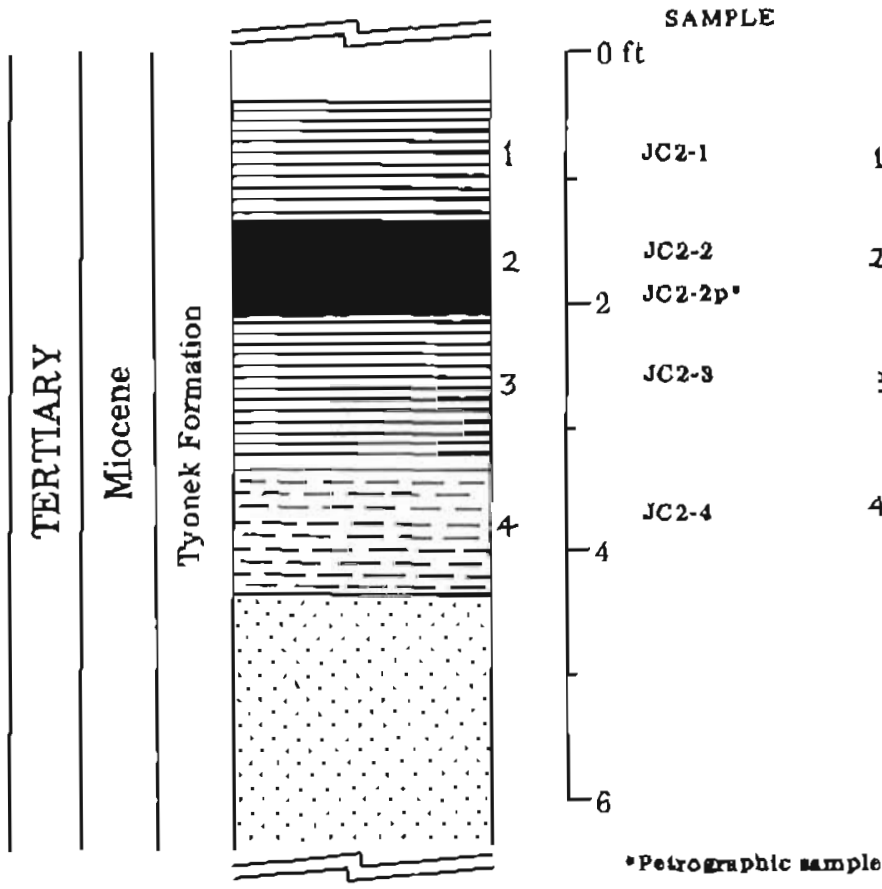

Sectlon includer 60-st ledge of sandstone, conglomorate, two other this coal beds, gavel, and surficial cover.

1 Shale, carbonaceous, black, hard, flssile, local trontoxide stainjos.

2 Cod, black, very hard, bright, glassy tracture. somianthradicic, oonchoidal fructure.

${ }^{3}$ Sbale, carbonaceous, ollvo-black (5Y2/1) to black (N1), Bastle. Uirm.

4 Claystone, oliveblack (5Y2/1) with black (N1) coaly stringers, thrm. Approximatoly 8 ft of claystone is followed downsectlon to craek level by sandscone, medium-kray, medlum-grnined, hard, 
JOHNSON CREEK SEAMS

SITE JC3

LITHOLOGIC DESCRIPTION

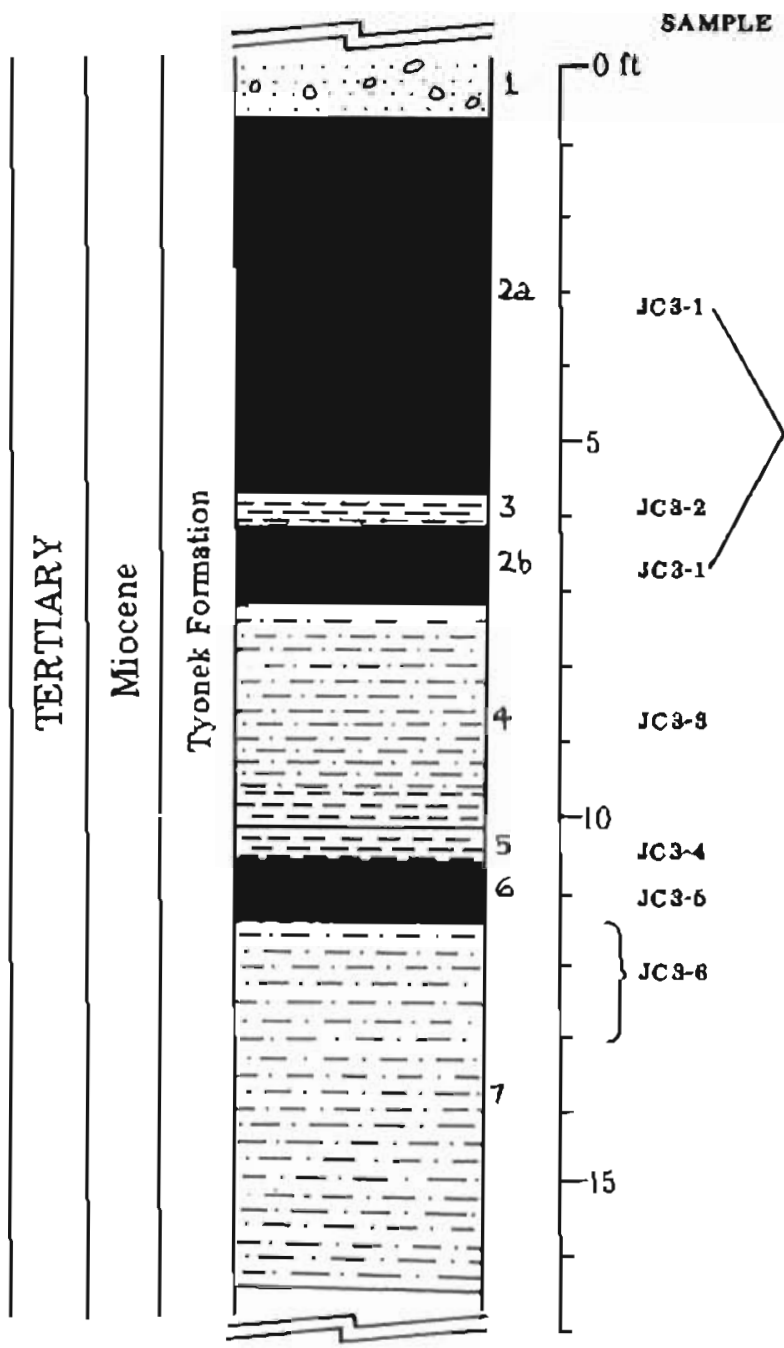

I Overburden seocion of approxbmately $30 \mathrm{ft}$ or peubly sandrione, conejomerate. Ind unconsolidated surflcin covor. locally hlghly whahed and aroded with coverad intervals.

24 Cod, bleok, dull, hurd, bony, tocally platy and wathered with iron-oxido stalning.

3 Parting: alaystone, light-brownigh gray (EYR6/1) with durt-gray (N3) carbonaceous (ncluationa and COA stringers. furro.

${ }^{2 b}$ Coul as above.

9 Claystone, sundy, llghfolive-gray (5Y6/1) with ollvableck ( $\left.0 Y_{2} / 1\right)$ carbonaccous (nclusions and dark-yo)lowloh-orango (10YR6/6) moetling; beromes less sandy and wore slley lowitud baso.

5 Claystane, dark-yoldowisb-brown (1OYH4/2) with darkgray (N3) carbonscoous strikgory and durk-yabowishorango (10YR6/6) moltling. flrm.

6 Conl, blhck, hisd, dull, bony, platy.

'T Clayetono, andy, Laht-ollvi-krny (EYi/l) with black (N1) coaly Incluslong und locul dark-yollowisd-orange (10YR6/6) mottllnk. firm. 
PETERSVILLE ARE^ SEAMS

SITE PAI

Sheet I of 3

LITHOLOGIC DESCRIPTION

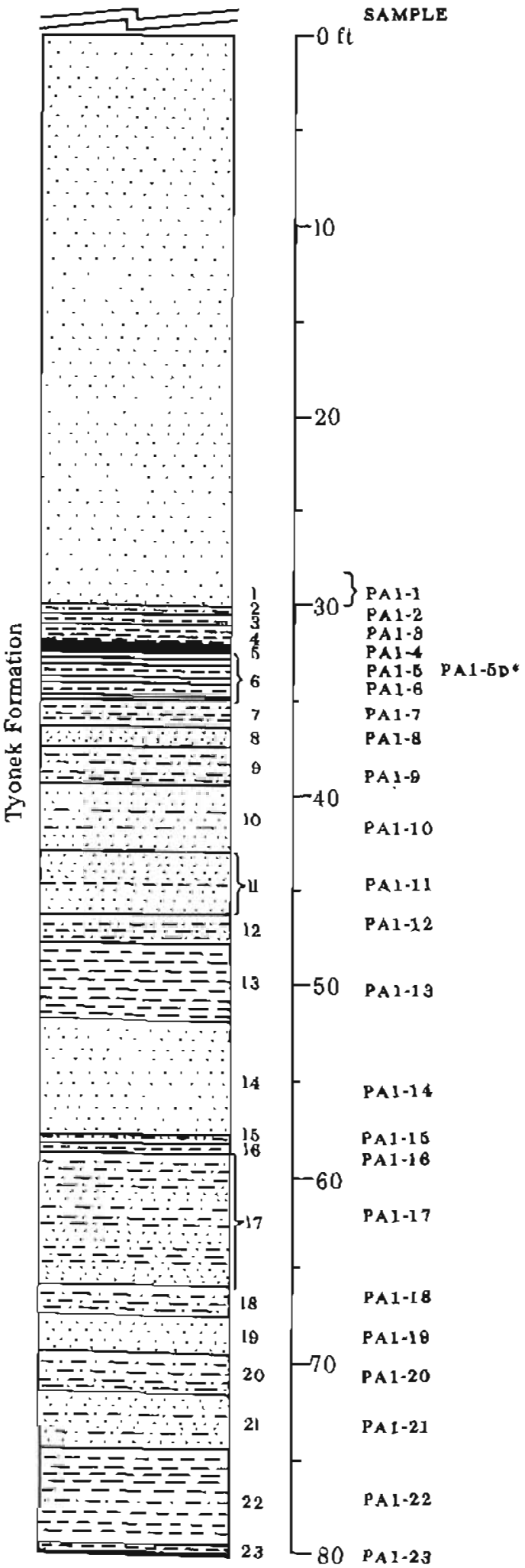

- Pocropraphic enmplo

1 Sandstone and sand, light-ollve-gray (5Y6/1) with black (N1) cody inclusions and Jocal paleyellowlsh-orange (LOYR8/6) motuling, coarse-balned, angular to subrounded, prenominantly quartz but arkosic, wegthered, prlablo. soti.

2 Claystone, sandy, moderaleyellowish-brown (1OYR5/4) dark-yellowish-orange (10YRG/B) and pale-yellowishorange (JOYRB/6) strenked, solt to firm, with distinctlve Eravels of brown amber and coaltied wood latbs.

3 Clay, Iaht-olive-aray ( 5 Y $6 / 1)$, very soft, plastic, pllable.

4 Claystane, medium-gray (NG) with grayish-black (N2) cody incluslons, firm, breeks in cancholdal blocks.

5 Coal, black, hard, dull. bons.

6 Shale, carbonaceous, modium-gray (N 5) to graylsh-black (N2), frm with transtlons to claygtone, medlum- to dark cray. Jocally carbonaceous, sulty to sandy, soft to firm.

7 Claystone, llght-ollve-gray $(5 \times 6 / 1)$ with dark-pray (N3) to black (N1) coaly inclusions and light-byown (5YR6/6) to modorate-bxown (6YR3/A)-oxidalion staindrk, gligh wy sandy, soft, with few Inohes of shaje, graylsb-purple (5P4/2), bounding top and basal portions.

8 Sand, clayey, llghtrolive-gray (6Y6/1), medium-gralnod, soft, loose.

9 Claystone, sandy, light-olive-gray (6Y6/1), so ft,

10 Sandstone, light-olive-gray (5Y6/1) with medium-dartaray (N4) carbonacoous plant tragmenta and flons, thro. clayey, with incerbedded claystone, sandy, modium-gray (N b), local tron-oxide staining.

11 Sandstone, lleht-olive-grag (5Y6/1) prodominunt (but "silt and poppex"), cosregrained, subangular to subrounded gralas. locally iron-stalned (limonlic) bands, frlable, soft; thlo (4 in.) layer of claystone. IIght-gray (N7), sllty, soft in oentar.

12 Claystone, sandy, modium-olive-gray ( 6 Y $6 / 1)$ and dar)yellowish-brown (1OYR4/2) sirenked, and black (N1) threadllke coal stringerg and fragments, soft: grades to claystone, medium-gray (ND) to onoderateyellowishbrown (10YR6/4) at base with stringers of conlifed wood.

13 Claystone, pajo-yellowisb-orange (10YR8/6) to yollowighgray (5Y7/2) with light-brown (6YR5/6)-watheng stroaks, (irm,

14 Sandstone, yelowistb-gray (5Y7/2) with local dark-ye) lowish-orange (10YR6/6) moltilng. medium-gralnod. Priable, firm.

15 Claystone, very sandy. Itghtodve gray (5Y6/1) witt fine gyaylsh-black (N2) and Ilght-brown (5YR5/8) incluslons, sof.

16 Claystone, olive-black (5Y2/1) with eraylah-black (N2) coaly inclusions, $4 \mathrm{rm}$

17 Claystone, sandy, graylsh-yelow (5Y8/4) to yellowlahgray (5Y7/2), yoft: asndstone, light (N 7)- to mediumgray (N5), mediura-gralned, trable, soft, with abundant limorile stuling, and wuabered loose sand, mediumto coarse-Eralned with iron-oxide staining.

18 Claystone, sandy, Ught-olive-gray (5Y8/1). firm, with a thin (roproximatoly 0.6 in.) coal stringer along lop.

19 Sandstone, yellowlsh-gray (5Y7/2), nyedlum- to coarse Exalnod, friable, soft to firm.

20 Claystone, olve-gray (EY //11), slighely aandy, soft to firm.

21 Sandscone, yellowish-gray (5Y8/L) with grayish-black (N2) brclusjons ("salt and gopper"), medium-gradred, soth, and claysione, sindy, firm.

22 Claystoge, Iighnolive-gray (6Y6/1), lirm, looally gilly to difghtly sandy witb common bometilic surface slaining.

23 Claystone and shale, interbanded, carbonacoous, darlegray (N3) to ollve-black (5Y2/1), tirm. 
PETEESUTLLE AREA SEAMS

SITE PAI

Sheet 2 of 3

LITHOLOGIC DESCRIPTION

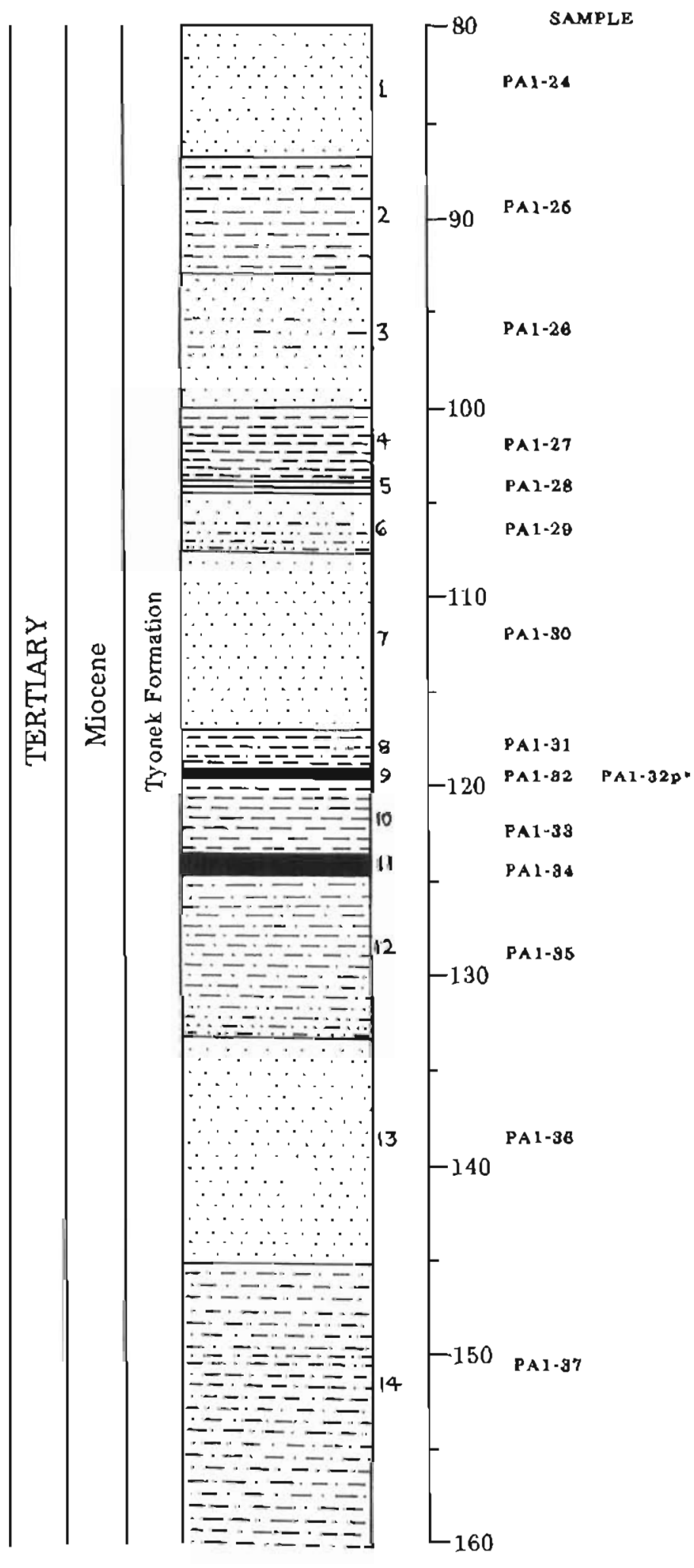

$\mathbf{1}_{\text {Sandstono and weathered loose sand, yellowleh-garay }}$ (5Y7/2) with pale-yellowlsh-orange (10YR8/6) mottling. modium-gralned, witl disseminuled black organic matter; crades to coarse-gralned, loose, dark-yellowishorarge (10YR6/6), and ne baso.

2 Claystone, olive-gmy (5Y4/1), slightly sandy, firm with abundart limonite and homallio stalning.

3 Sundstone, Light-olve-aray (DYG/1) with dark-yellowiahorange (IOYR6/6)-wealberlng stains, medlum-gralned, locally olphtly clayey, (ujuble.

4 Claystont, Lght-obve-gray (5Y6/1) to medlum-olivegory (DY $6 / 1$ ), aldghtly whly, firm.

5 Sbol6, ourbonacaous, roodium-gray (N5) to grnyish-black (N 2). Lissil o. firm.

¿ Sandstonc, clayey, Ilght-ollve-gray (5Y6/1) with ligbtbrown (EYR5/6) mottling, abundant ellssomlratod black organde mateor and muscovito.

7 Sand, yollowlah-gray (5Y7/2), nedium-gralaod, soft, looso witb abundant limonlte staining.

R Claystono, Hght-gray (N7), slightly sandy, colt.

9 cont, bluck, rirm, dull, platy.

10 Clay atone, Ifglst-gray (N7), glightly sdly, soft.

II Cos, black, dull, hard, bony.

12. Claystone, sandy, ILeht-gxay (N7) with black (N 1) coaly lnclusions and tocal pale-yollowiah-orango (10YR8/6) mothling, and soft, at top; grades to sand. modiudo-gxay (ND), linergrulned, clinyey, loose, soft loward besh gorllon.

13 Send, graylsh-orange (1OYR7/4) and Ilghtwolive-kray (5Y6/1), medium-grained, goft with ebundent limonite staining and dlsseminatod bluck organic raater.

14 Claystone, rodium-olve-aray (6Y6/1), slifhtly sandly to sandy. flrm-goft.

- Potrocraphic momole 


\section{PETERSVILLE AREA SEAMS \\ SI'TE PAI \\ Sheet 3 of 3}

LITHOLOGIC DESCRIPTION

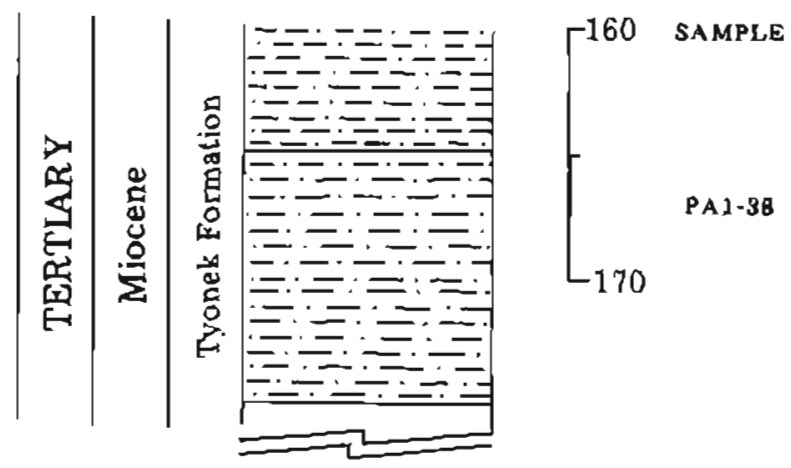

Claystone, sandy, light-aray (NT), fron.

Sectlon discontinued at Short Creek loved.

PETERSVILLE AREA SEAM

SITE PA 2

LITHOLOGIC DESCRIPTION
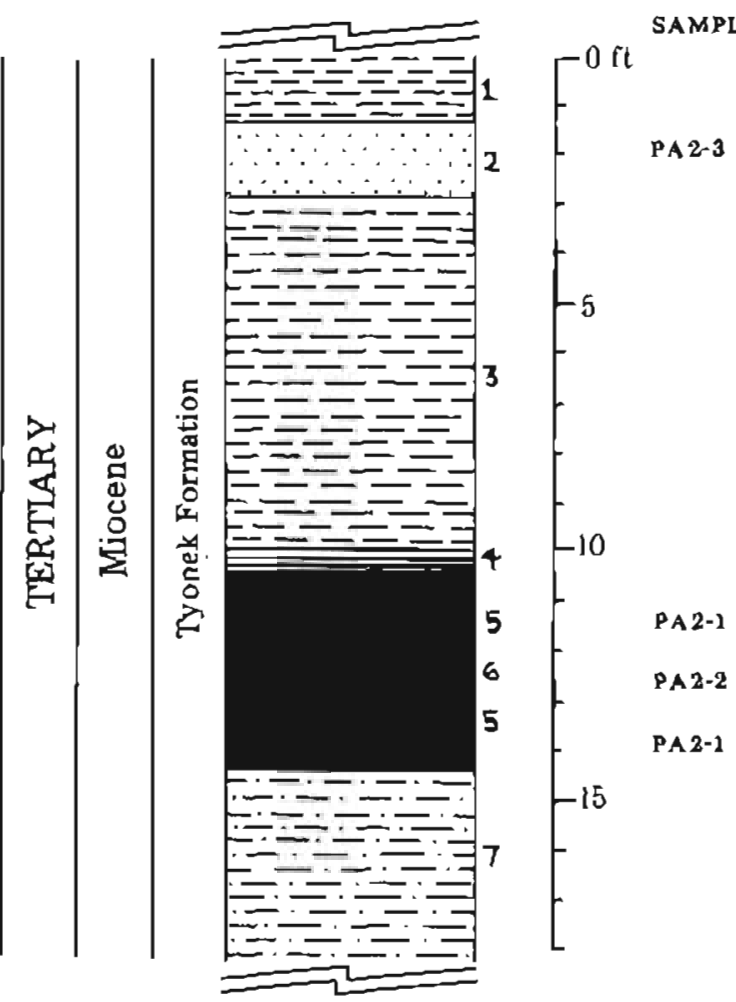

1 Claystone, medium-Eray (NE), firm.

TGraywacke, predominanily olve-pxay (EYA/L) witb Ilght-ollve-gray ( $6 Y 6 / \lambda$ ) Inclusions, oarbonaceous. feldspathic: stands in reller withls sotter claystone undt.

3 Claystone, medium-gray (N5), sllghtly carbonaceous and silty, firm.

Fshale, carbonaceous, black (N1), llsado, firm.

5 Coal, black, dull, hard. blocky in center section, woody toward top and basal portions.

- Claystone (posslbly valeanle ash), medium-light-gray (N6) with gray ish-black (N2) coaly Loclustons and darkyellowish-orange (10YR6/B) mottl lng. firm.

SEATROCK (URdenclay)

I Claystone, sandy, medium-gray (NG), tlum, locally ltmondte-stalned. 
PETERSVILLE AREA SEAM

SITE PAS

LITHOLOGIC DESCRIPTION

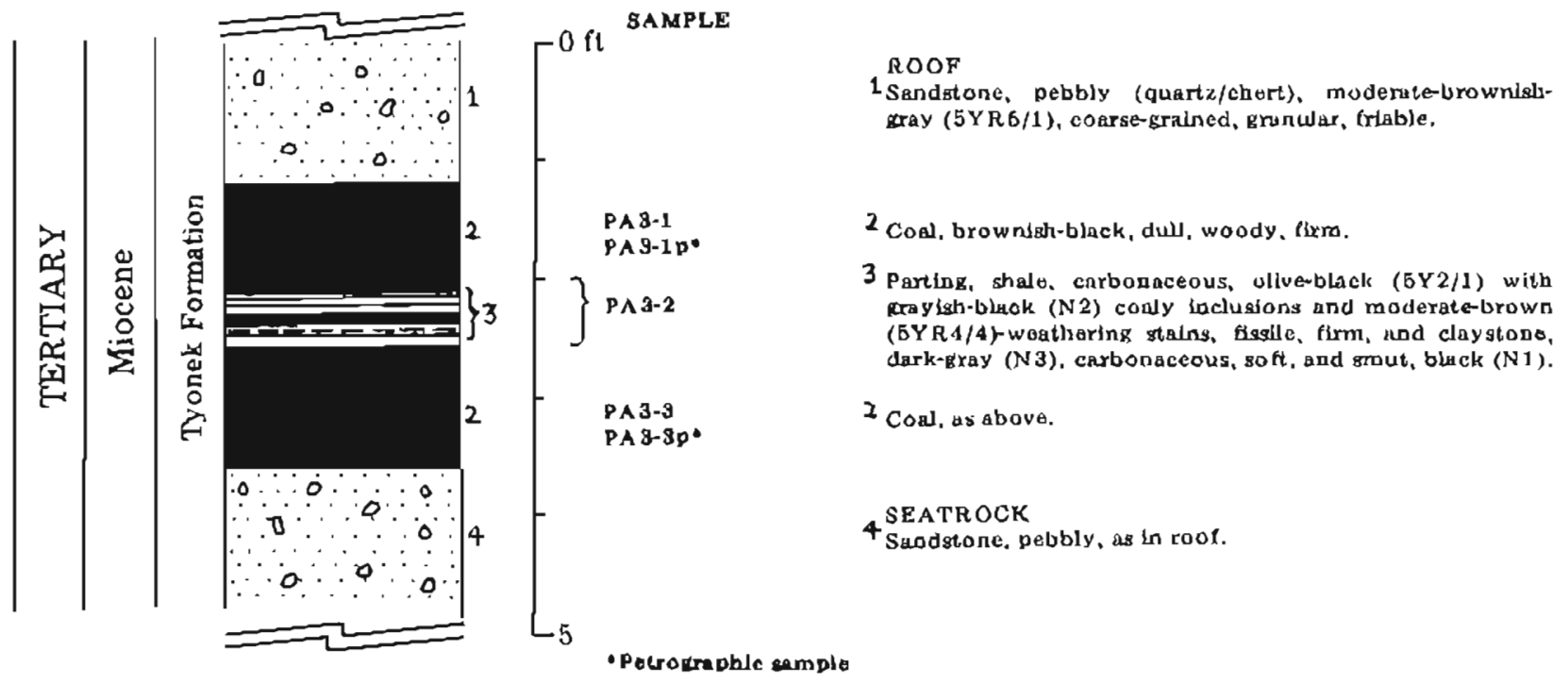

TALACHULITNA RIVER SEAM

SITE TR I

LITHOLOGIC DESCRIPTION

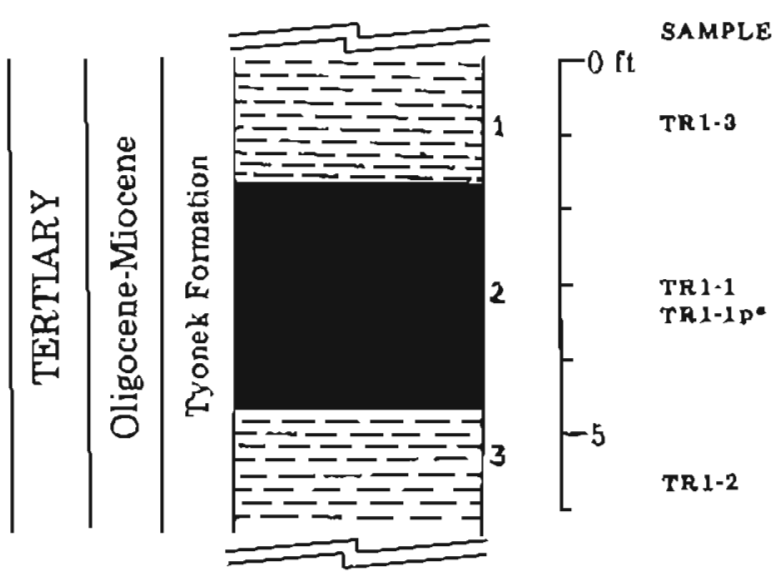

\begin{abstract}
ROOF
1 Claystone, medum-olfve-gray (5Y5/1), abundant limonite and hematite staining. Weatbers to yellow and orange suingles and coneboidal blocks, sort.

2 Coa, brownish-black, dull, woody, ashy, locally slighuy conlorted.

3 SEATROCK (underclay)

Claystone, (Jght-ollve-gray $(6 Y 6 / 1)$ with local legh-brown (5YR $5 / 6)$ motthing and staining.

Section discontinuod at wator Icvol, Metamorpbosed JK grenstono towled and juxtaposed ngalost coal apDroximately $100 \mathrm{ft}$ upatraam.
\end{abstract}

- Potromaphlo mample 
SATURDAY CREEK SEAM

SIT'E SC2

LITHOLOGIG DESCRIPTION

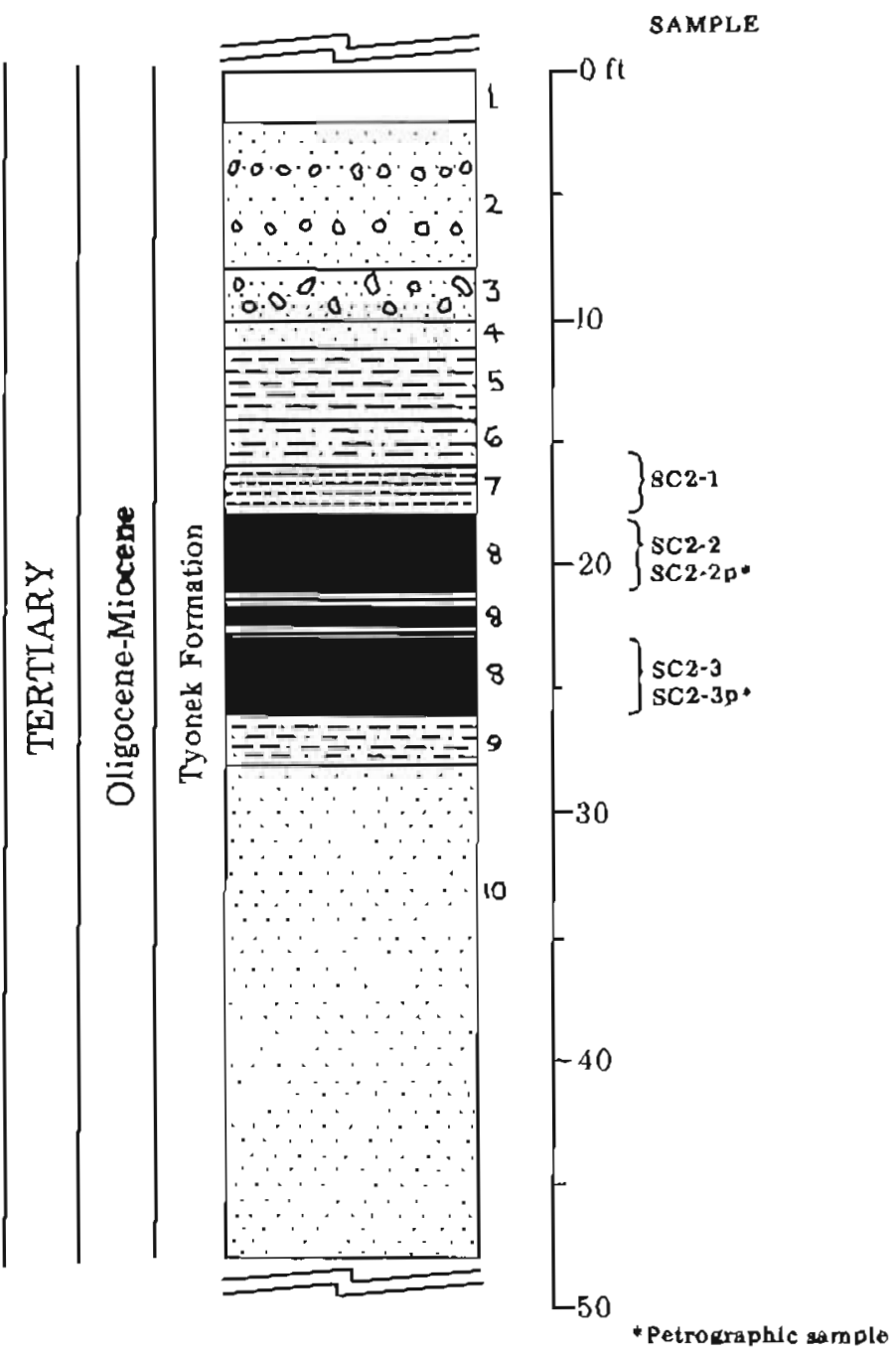

1 Surficlal cover, brown eandy loam.

2 Sindstone, medlum-gray, medium-grained, with yelow iron-oxlde stajning locally: Interbands of quartzrpebble conglomerate (pebbles to $2 \mathrm{ln}$. diameter) up to $0.6 \mathrm{ft}$ thIck.

3 Conglomerate, monomichic, quartz-pobble, hard, wollcemerled.

4 Sandstone, medium-yollow lsh-pray, medium-pralned, bard, with ourfloid bron-oxide-weathoxige stains.

5 Glnysione, darle-gray, carbonaceous, firm.

6 Claystone, sandy, lightray, firm.

7 Claystone, madlum-lighigray (N6) wlth black (N1) coaly incluslons and light-brown (GYRb/6)-weathering stalns, flum, breaks conchoilal traccure.

8 Coal, black, blocky, hurd: mldalo has black, earbontceous shajo, partings.

SEATROCK (underclyy)

a Claystone, light.rary. sllahuy sardy, flrm.

10 Sandstono, modium-yellowish-cray, medlum-grained, very loard, surfictal fron-oxldo-weatherlng stuins. 
SATURDAY CREEK SEAM

SITE SC3

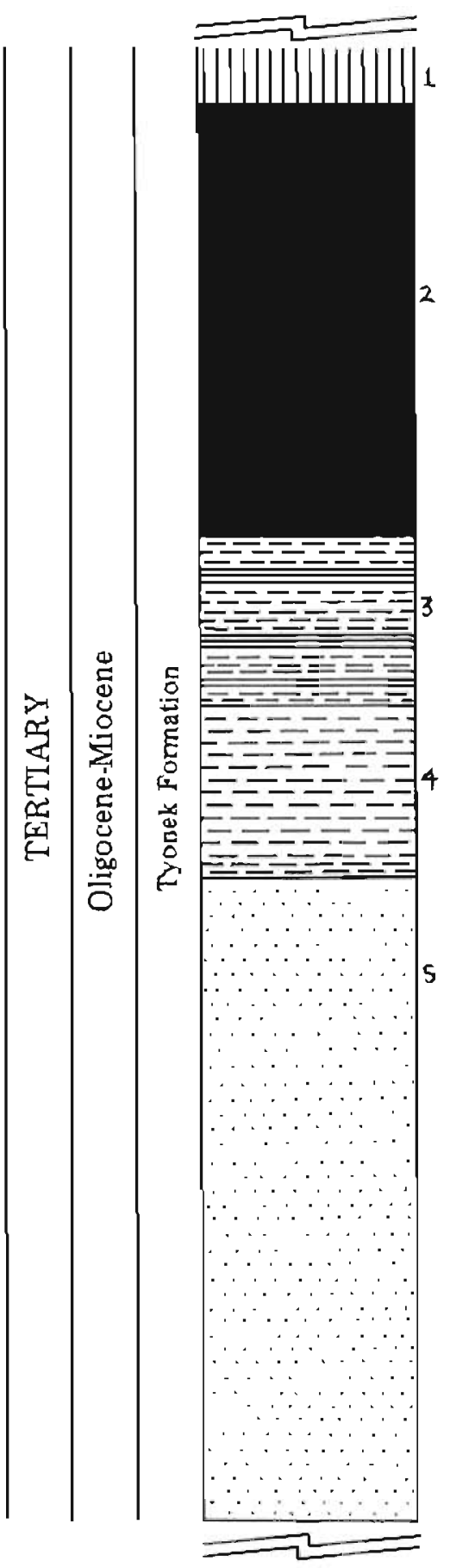

SAMPLE

LITHOLOGIC DESCRIPTION

1 Rool not exposed : covered interval.

2 Cod, black, dull, platy, bony, hlghly weathered on surface.

\begin{abstract}
SEATROCK
3 Claytone, brownish-pray (6YR4/1), looally aurbonaceous, $\mathrm{Irm}$ to soth, with light-brown (6YAS/8) Lronoxide stalulng: inearbodded wilb ghalo, carbonaceous, black (N1), Plssile, Brm.
\end{abstract}

4Claystone, lightregay (N 7) to light-alivegnay (6Y6/1), looally silghily carbonaceous. firm lo sott, breaks with concholdal tracture.

J Sandstone and sand, yellowish-gray (6Y7/2) to lightollve-gray ( 6 Y $6 / 1)$, medlum- to coarse-gralned, angular to subrounded grains, dissemlnaled line black organic mallor and muscovite, but predominantly quartz sand, frlable lo loose. 
SATURDAY CREEK SEAMS

SITE SCA

SAMPLE

LMTHOLOGIC DESCRIPTION
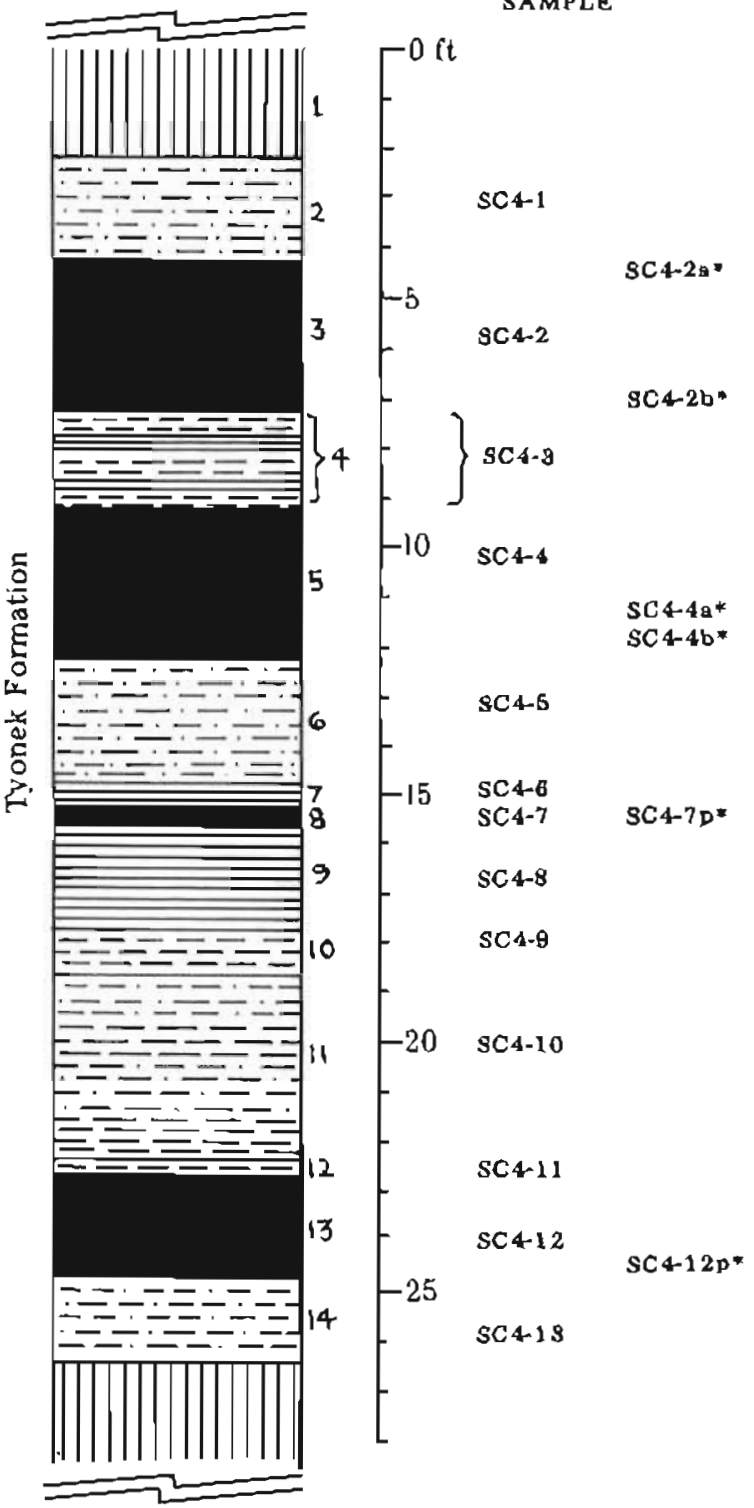

1 Covered interyal for 80 th to top of ridge.

2 Claystone, sandy, ollveray (5Y4/1) with dark-vol. lowlsh-orangc (10YR6/6)- to Hght-brown (5YRS/6) weathering mottles.

3 Cod, black, hard, brght, blocky.

4 Claystone, gayish-blook (N2), carbonectous, trm, rooled, and shale, carbonncyous, dark-eray ( $N a)$ lo bleck (N1). fissillo und fixm, intercalated.

5 coal, black, brikht, hard, platy: bocomes bony toward basal portion.

${ }^{6}$ Claystone, sandy, Iighlolite-gray (5Y6/1) ivith blaok (N1) coaly inclusions and local dark-yellowlshorange (10YR6/6) wealher banding, firm.

7 Shale, carbonacous, aray Lsh-black (N2). fisslle, weathered and so ft.

¿coal. biack, very hard, broaks concholdal fracture, posslbly cannel coal.

S shalo, carbonacoous, nedlum-daric-pyay (N4) to black (N1), flssila, firm.

10 Claystonc, lifhraliverray ( $5 \mathrm{YB} / 1$ ), with disseminated black organic maller, rooted, hemallestained, soft.

11 Gaystone, ligjit-olive-pray (5Y6/1) with modium-dark eray (N4) corly inclusions and local dark-yellowlaborange $(10 Y R 6 / 6)$ mottling. slightly sandy, breaks with conchoidal traclure.

12 Claystone, medium-ollve-gray (5Y5/1) with black (NI) coaly Inciusions and local dark-yellowiah-ortage (10YRG/O) mottling, firm.

13 Cod, black, tull, hard, plaly, bony.

it Claystone. olive-gray (6Y4/d) with dark-kray (N3) couly inclustons, slighly sandy. firm, locally llmonite-stained.

Covered interval for 30 it doiun to creak loyel.

- Pacrozraphie sumple 
SKWENTNA RIVIG SEAM STTE SR 1

LITHOLOGIC DESCRIPTION

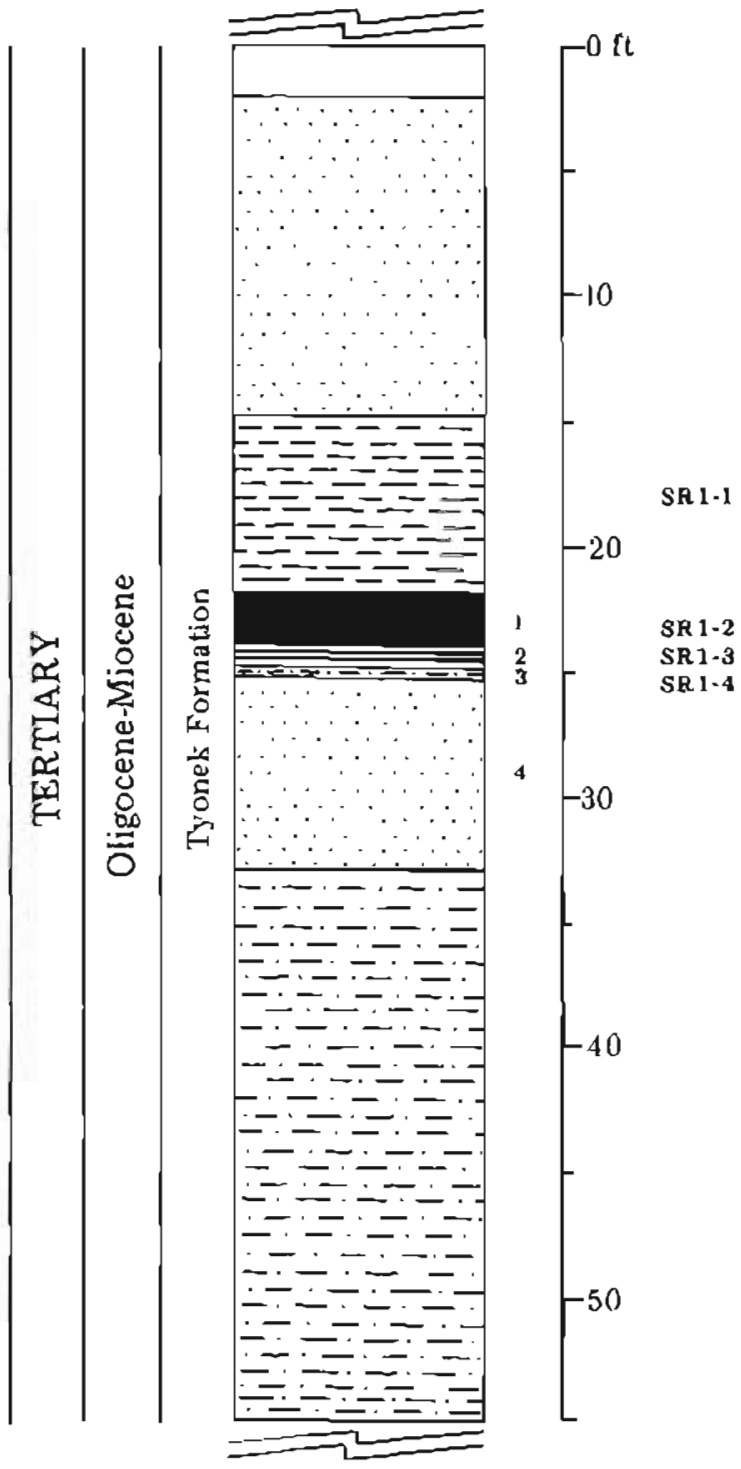

Surfictal cover; lightbrown sandy loam.

Sand, light-yollow to brownish-yellow, medium-grabined, loose, soft, weathered with tron-oxlde gtaining.

Chaystone, medium-olive gray (6Y6/1), slighcly carbowa ceous, flrm, breaks with concholdal fracturo.

SR \-5

SRI-6*

I Coal. black, dull, thinly plated. bony.

2 Shule, carbonaceous. dark-kay (Ni) to graylsb-black (N2) forile bighly weathored soft.

3 Claystone, sandy, Lght-abvergray (5Y6/1) with olivearay (EY 4/1) streaks, carbonaceous, firm.

4 Sand, yellow to orange, medlum-kralned. blahly weatb. exed with tron-oxide stalning, disgeralnatod black onganle malter, micacooug loose.

Claystonc, sandy. durk-gray, curbonacoous, soft-flum. 
WOLVERINE CREEK SEAM

SITE WCI

LITHOLOGIC DESCRIPTION

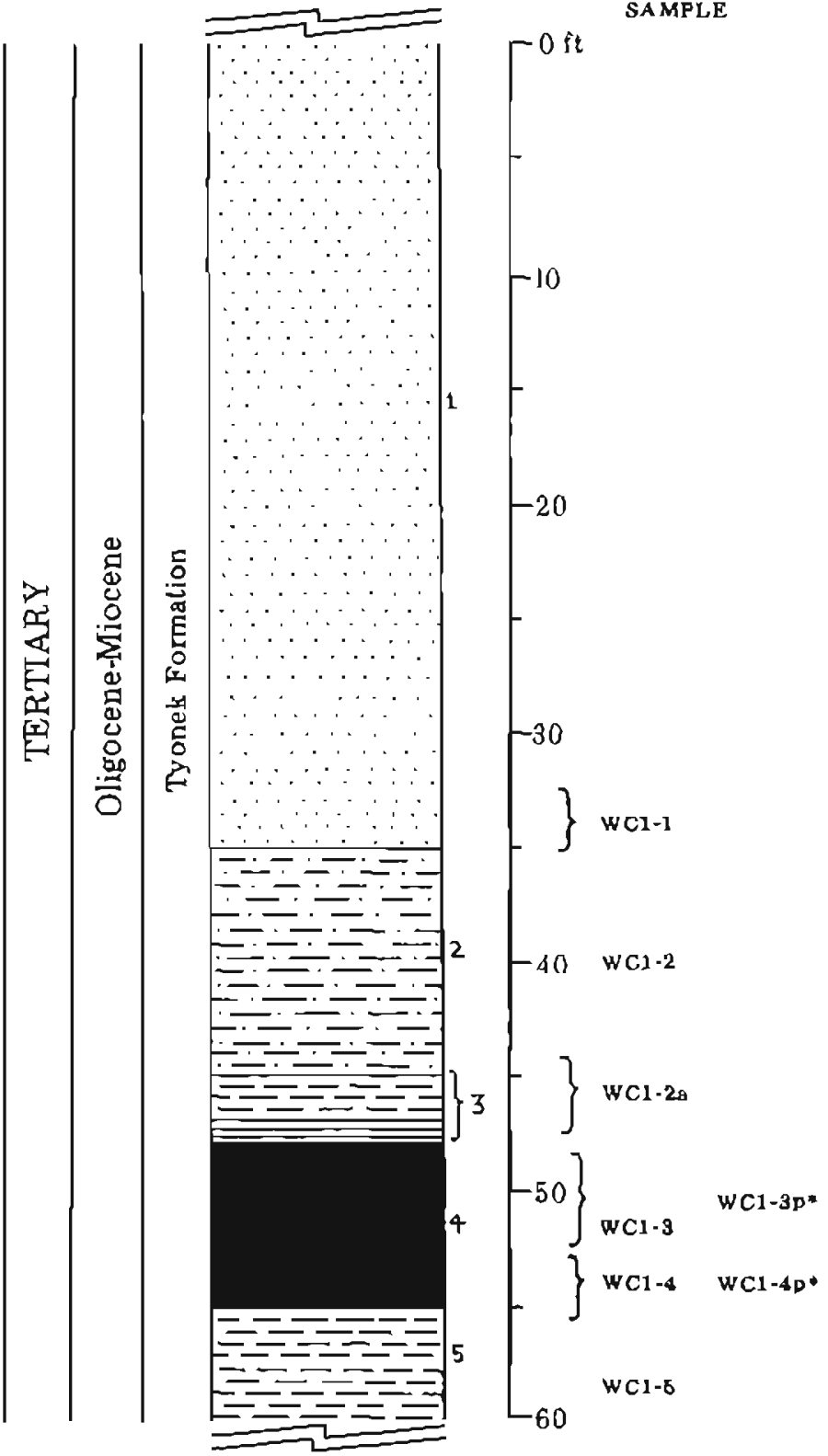

'sandstone, light-ollue-gray (5Y6/1) speckled ("galt and Deppor") with wbite (NB) and medlum-light-pray (N6), ooarse-grained, angular to subangular prulng, triable, soft-firm.

2 Claystono, sandy, medlum-light-gray (N6) strenked medium-dark-kray (N4), soft, breaks in blookg, abundant Ilmoalte stains along surfices add joints.

3 Claystone, Brayish-black (N2) with ollvegray $(5 Y 4 / 1)$ streaks, carbonaceous, sofh. and shale, carbonacous black (N 1), Ilssilo, soft.

4 Coal black, Dredomlnantly braphe, bard, blocky; basal 3 it highly weathered and limonite-stained.

5 SEATROCK (underclay)

Claystone, modium-gay (NG) with abundant daxk-yellowlsh-orange (10YR6/6) staining, so (t.

- Petrographle enmple 
WOLVERINE CREEK SEAM SITE WC2

\section{LTTHOLOGIC DESCRIPTION}
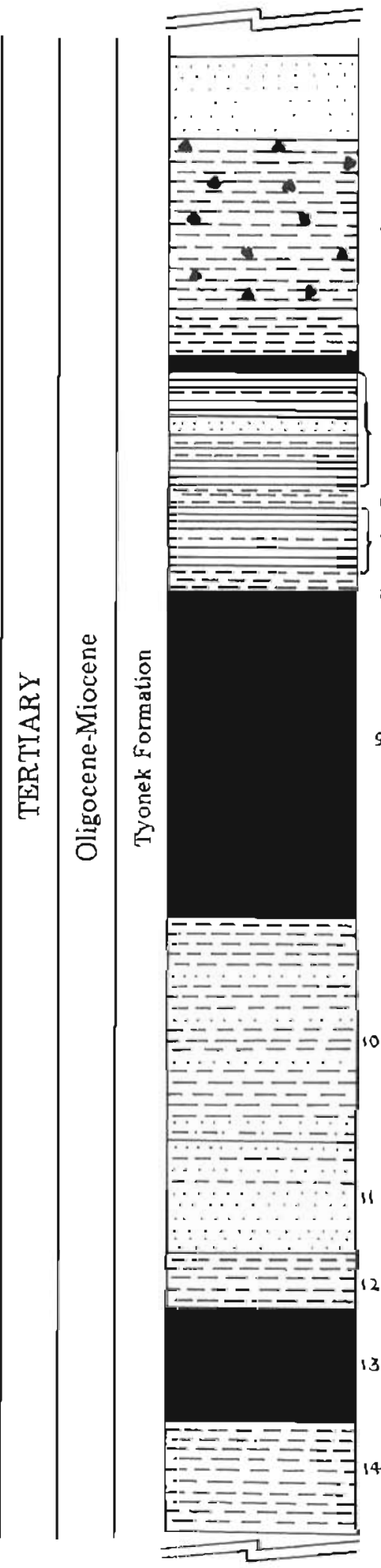

SAMPLE

1 Sandstono, lighl-gray (N7) with dark-yellowlsh-orange (10YR6//) moltles, coarse-graimed, Jocally clayey and slightly carbonacoous, "agit and pepper."

WC2 -1

2 Claystone, olive-gray (6Y//1), soft to clron, breaks in blocky mases, abundant Iron-rlct (limonito rim, hematite core) septarian nodulos.

3 Claystone, brownish-gray (5YRA/1) with prayish-black (N 2) strosks and inclusions, soft.

A Coel stringer, black, hard, plety to elightly blocky.

5 Shale, carbonaccous, ollve-black (EY2/1) with darkyellowlsh-orange (1OY $46 / 6$ ) mottles, fiswle, firm, Interlayered with claystone, browniab-eray (6YR4/1), locally ulty, ubundant Innonite stajns alonk sucfoces and bedding planes; central $(0.6 \mathrm{ft}$ ) layer of stndstone, graylsh-brown (6YR\$/2). medium-gralnod, hard, tron-stalned.

6 Claystane, olive-gray (5Y 4/1) with lisht-brown (5YR5/6) woutles, locally slifhtly crubonaceous and iron-stalned. soft to frrm.

7 Shale, carbonaceous, dark-grny (N3) wilb light-brown (5YR6/6)-weathoring stains, fisalle, soft to firm, literbunded with olsyatone, dark-gray (NJ), carbonaceous. soft.

8 Claystone, dark-yelJowish-brown (10YR4/2), slpbuly suty and curbanteceus, soft.

¿ Coa, bluck, dull, flrm to hard, blocky, weathared locally wlth abundant iron-ox dde stalning.

$W C 2-10 b *$

WC2-11

10 Claystono, very shady, ILght-ollve-gray (GY6/1), sort, locally with abundnni tron-oxlde stainina: inlcrbended with sand lenses, ILhl-sray (N7), mediugrogalned, micaceous, frlable, soft.

1 Sandstone, liebtolivegray (5YG/1) streaked olive-gray roedium-grained, (trable, soft abundant limontto stalnlng:

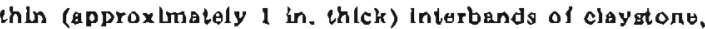
medium Rxay (N5), odly, soth, loward loD.

12 Claystone, Ught-gray (N7), breaks with blocky, conoholdal Practure, abundarl iron-oxtale staining.

WC2-13

I Coal, black, dul, hard, blocky, locally weachered with abundant limonito stalning.

WC2-14

WC2-14p

${ }^{14}$ C)aystone, lisht-olive-gray (5Y6/1), sdity, soft.

WC2-16 
APPENDIX D

Calculations for Statlstical Markov Chain Analysis 


\section{APPENDIX D}

Calculations for statistical Markov-chain analysis (after Gingerich, 1969). Refer to text for discussion of results.

A. Prequency of occurrence of five rock types:

\begin{tabular}{|c|c|c|}
\hline Shale (SH) & 5 & \\
\hline $\mathrm{Coal}(\mathrm{CO})$ & 7 & \\
\hline Claystone (CL) & 12 & \\
\hline Sandstone (SS) & 8 & \\
\hline Conglomerate (CG) & 4 & \\
\hline
\end{tabular}

B. Independent-trials matrix:

$\begin{array}{lllllll} & \text { SH } & \text { CO } & \text { CL } & \text { SS } & \text { CG } & \\ \text { SH } & 0.00 & 0.22 & 0.39 & 0.26 & 0.19 \\ \text { CO } & 0.17 & 0.00 & 0.41 & 0.28 & 0.14 \\ \text { CL } & 0.21 & 0.29 & 0.00 & 0.33 & 0.17 \\ \text { SB } & 0.18 & 0.25 & 0.43 & 0.00 & 0.14 \\ \text { CG } & 0.16 & 0.22 & 0.38 & 0.25 & 0.00\end{array}$

C. Transitjon count matrix:

\begin{tabular}{|c|c|c|c|c|c|c|}
\hline & & $\mathrm{CO}$ & $C L$ & SS & $C G$ & \\
\hline SH & 0 & 0 & 3 & & 2 & \\
\hline $\mathrm{CO}$ & 4 & 0 & 2 & & 0 & \\
\hline CL & 1 & 6 & 0 & & 1 & $=f_{i j}$ \\
\hline SS & 0 & 1 & 6 & & 0 & \\
\hline $\mathrm{CO}$ & 0 & 0 & 0 & 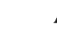 & 0 & \\
\hline
\end{tabular}

D. Transition probability matrix:

$\begin{array}{lllllll} & \text { SH } & \text { CO } & \text { CL } & \text { SS } & \text { CG } \\ \text { SH } & 0.00 & 0.00 & 0.60 & 0.00 & 0.40 \\ \text { CO } & 0.67 & 0.00 & 0.33 & 0.00 & 0.00 \\ \text { CL } & 0.08 & 0.80 & 0.00 & 0.33 & 0.08=\mathrm{Pij}_{\mathrm{i}} \\ \text { SS } & 0.00 & 0.14 & 0.86 & 0.00 & 0.00 \\ \text { CG } & 0.00 & 0.00 & 0.00 & 1.00 & 0.00\end{array}$

E. Calculation of $x^{2}$ statistic

$\chi v^{2}=\sum_{i j}\left(f_{i j} \cdot f_{i} e_{i j}\right)^{2} / f_{i} e_{i j}$

The number of positive elements in $\mathbf{e}_{j \mathrm{j}}$ is 20 .

The rank of $\theta_{i j}$ is 5 . The rank of a matrix is the maximum number of independent row vectors or column vectors. The rank is determined by converting the matrix to row echelon form and finding the number of non-zevo rows or columns (Hawkins, personal commun,. 1982).

Echelon form of matrix:

\begin{tabular}{lrrrrr} 
& \multicolumn{1}{c}{ SH } & CO & \multicolumn{1}{c}{ CL } & SS & CG \\
SH & 1 & 0 & 2.58 & 1.65 & 0.82 \\
CO & 0 & 1 & 1.77 & 1.18 & 0.59 \\
CL & 0 & 0 & 1 & 0.34 & 0.16 \\
SS & 0 & 0 & 0 & 1 & 0.18 \\
CG & 0 & 0 & 0 & 0 & 1
\end{tabular}

The degrees of freedom are 15. This is determined by subtracting the rank of $e_{i j}$ irom the total number of positive entries:

$$
v=20 \cdot 5=15
$$

Solving for the equation yields an $\chi^{2}$ of 35.9 . 


\section{Appendix $D$ (con.)}

F. Difference matrix:

SH CO CL SS CG

$\begin{array}{llllll}\text { SH } & 0.00 & -0.22 & 0.21 & .0 .28 & 0.27\end{array}$

$\begin{array}{llllll}\mathrm{CO} & 0.50 & 0.00 & -0.08 & -0.28 & -0.14\end{array}$

CL $\quad 0.13 \quad 0.21 \quad 0.00 \quad 0.00 \quad-0.09=p_{i j}-e_{j j}$

$\begin{array}{llllll}\text { SS } & -0.18 & -0.11 & 0.43 & 0.00 & -0.14\end{array}$

$\begin{array}{lllllll}\text { CG } & -0.16 & .0 .22 & -0.38 & 0.75 & 0.00\end{array}$

The positive eloments in the difference matrix represent those Iransitions that have a higher than random probability of occurring. 
APPENDIX E

Overburden-characterization Data 
Table E-1. Overburden procedures and references.

\begin{tabular}{|c|c|c|c|}
\hline Parameter & Unit & Procedure & Reference \\
\hline Paste $\mathrm{pH}$ & $\mathrm{pH}$ & Electrode & $\begin{array}{l}\text { USDA }(1954), \text { p. } 102 \text {; } \\
\text { Sobek and others, } \\
1978, \text { p. } 45.47 \text {. }\end{array}$ \\
\hline Electrical conductivity & $\mathrm{mmhos} / \mathrm{cm}$ & Gonduclivity bridge & USDA (1954), p. 89 \\
\hline Saturation percentage & $\%$ & Dried to $105^{\circ} \mathrm{C}$, weight loss & USDA (1854), p. 10 \\
\hline $\begin{array}{l}\text { Water-soluble cations } \\
(\mathrm{Ca}, \mathrm{Mg}, \mathrm{Na})\end{array}$ & $\mathrm{meq} / \mathrm{l}$ & $\begin{array}{l}\text { Vacuum extraction, atomic } \\
\text { absorption }\end{array}$ & USDA (1954), p. 84 \\
\hline SAR & (ratio) & $\begin{array}{l}\text { Calculation from water-soluble } \\
\text { calions }\end{array}$ & $\begin{array}{l}\text { USDA }(1954), \text { p. } 26 \text {, } \\
\text { p. } 72-76\end{array}$ \\
\hline ESP' & $\%$ & Extraction & $\begin{array}{l}\text { ASA (1965), part 2, } \\
\text { p. 1033-1034. }\end{array}$ \\
\hline Boton & ppm & $\begin{array}{l}\text { Hot-water soluble, Carmine } \\
\text { method }\end{array}$ & $\begin{array}{l}\text { ASA }(1965) \text {, part 2, } \\
\text { p. } 1062-1063 \text {. }\end{array}$ \\
\hline Selenium & ppm & $\begin{array}{l}\text { Hot-water extraction, hydride, } \\
\text { atomic absorption }\end{array}$ & $\begin{array}{l}\text { ASA (1966), part 2, } \\
\text { p. } 1122 .\end{array}$ \\
\hline Acid-base potential & $\begin{array}{l}\text { tons } \mathrm{CaCO}_{3} \text { equivalent } 1,000 \\
\text { tons soil material }\end{array}$ & $\begin{array}{l}\text { Total sulfur, } \% \mathrm{CaCO}_{3} \text {, titration } \\
\text { and turbidimetric }\end{array}$ & $\begin{array}{l}\text { Sobek and others, } \\
1978, \text { p. 47-65. }\end{array}$ \\
\hline $\operatorname{Lim} \theta$ & $\%$ & $\begin{array}{l}\mathrm{CaCO}_{3} \text { exuivalent from acid } \\
\text { neutralization }\end{array}$ & USDA $(1954)$, p. 105 \\
\hline Sulfur & $\%$ & Leco method & $\begin{array}{l}\text { Leco (1975), p. I- } \\
61 \text { : Sobek and others, } \\
1978 \text {, p. } 51-55 \text {. }\end{array}$ \\
\hline
\end{tabular}


Table E.2. Physical and chemical data

\begin{tabular}{|c|c|c|c|c|c|c|c|c|c|c|c|c|c|c|c|c|}
\hline \multirow[b]{2}{*}{ Sample } & \multirow{2}{*}{$\underset{\text { (paste) }}{\mathrm{pH}}$} & \multirow{2}{*}{$\begin{array}{c}E C^{8} \\
\text { (mmhost } \\
\operatorname{cin})\end{array}$} & \multirow{2}{*}{$\begin{array}{l}\text { Sat } \\
(\%)\end{array}$} & \multicolumn{3}{|c|}{$\begin{array}{c}\text { Saturation } \\
\text { extract } \\
\text { cations } \\
\text { (meg/l) } \\
\end{array}$} & \multirow[b]{2}{*}{ SAR $^{d}$} & \multicolumn{4}{|c|}{$\begin{array}{c}\text { Particle-size } \\
\text { analysis } \\
\text { hydrometer }\left(g_{6}\right)\end{array}$} & \multirow[b]{2}{*}{ Texture } & \multirow{2}{*}{$\begin{array}{l}O M^{c} \\
(\%)\end{array}$} & \multirow{2}{*}{$\begin{array}{l}\text { Lime } \\
(\%)\end{array}$} & \multirow{2}{*}{$\begin{array}{l}\text { Total } \\
\text { boron } \\
\text { (ppm) }\end{array}$} & \multirow{2}{*}{$\begin{array}{c}\text { Se } \\
\text { (ppm) }\end{array}$} \\
\hline & & & & $\mathrm{Ca}_{a}$ & $\mathrm{ivg}$ & $\mathrm{Na}$ & & EsPe & Sand & Sili & Clay & & & & & \\
\hline BR1.2 & 6.6 & 0.2 & 17.1 & 1.4 & 1.0 & 0.8 & 0.5 & 2.8 & 36 & 25 & 39 & $\mathrm{CL}$ & 2.67 & 9.5 & 54.5 & $<0.01$ \\
\hline$B R 1 \cdot 3$ & 6.9 & 0.4 & 36.1 & 2.8 & 1.8 & 0.8 & 0.4 & 3.8 & 29 & 55 & 16 & SiL & 1.07 & 9.8 & 100.0 & $<0.01$ \\
\hline BR 1.5 & 6.4 & 0.6 & 42.9 & 4.2 & 2.9 & 0.6 & 0.3 & 35.0 & 49 & 32 & 19 & $\mathrm{~L}$ & 6.54 & 10.0 & 60.8 & $<0.01$ \\
\hline $\mathrm{BR} 1 \cdot \mathrm{B}$ & 6.3 & 0.3 & 48.0 & 2.1 & 1.2 & 0.7 & 0.5 & 5.5 & 7 & 77 & 16 & SiL & 1.91 & 9.9 & 1.3 & $<0.01$ \\
\hline BRl.7 & 6.1 & 0.9 & 42.8 & 6.3 & 4.4 & 0.8 & 0.3 & 3.0 & 60 & 21 & 10 & St & $5.3 \mathrm{I}$ & 9.5 & 39.5 & $<0,01$ \\
\hline BR1.9 & 6.9 & 0.2 & 46.3 & 1.4 & 0.7 & 0.6 & 0.6 & 8.0 & 8 & 74 & 18 & SiL & 1.97 & 9.7 & 36.8 & $<0.01$ \\
\hline BR1.10 & 6.9 & 03 & 34.7 & 2.0 & 1.2 & 0.6 & 0.5 & 8.4 & 46 & 45 & $\theta$ & L & 0.96 & 9.8 & 16.7 & $<0.01$ \\
\hline BR1.11 & 6.8 & 0.2 & 42.6 & 1.7 & 1.0 & 0.6 & 0.5 & 3.2 & 51 & 38 & 11 & L & 2.82 & 9.7 & B.3 & $<0.01$ \\
\hline $\mathrm{BR} 1 \cdot 13$ & 6.5 & 0.3 & 46.0 & 1.6 & 1.2 & 0.6 & 0.0 & $5 . \mathrm{L}$ & 11 & 55 & 34 & SiCL & 3.16 & 10.0 & 59.3 & $<0.01$ \\
\hline BR1-14 & 6.4 & 0.3 & 37.3 & 1.4 & 0.9 & 0.6 & 0.6 & 12.7 & 56 & 35 & 9 & L & 1.20 & 8.8 & 25.5 & $<0.01$ \\
\hline BRI-16 & 6.7 & 0.4 & 4 di. 0 & 2.8 & 2.2 & 07 & 0.5 & 3.8 & 10 & 45 & 45 & $\mathrm{SiC}$ & 2.27 & 9.9 & 15.7 & $<0.01$ \\
\hline
\end{tabular}

Electrieal conducivity.

b Saluration perceniage.

Corganic inalior.

Sodrum adsorption ratio.

Exchangeable sodium percentage.

${ }_{\mathrm{C}}^{\mathrm{E}} \cdot \mathrm{Cl}$. $\mathrm{y}$

L. Loam

$S-$ Sand

Sı. Silk.

Eiveulralizalion polentlad.

holential acidity (positive values indicate excess $\mathrm{CaCO}_{3}$-basic overburden maleral).

Table E-3. Physical and chemical dala on

\begin{tabular}{|c|c|c|c|c|c|c|c|c|c|c|c|c|c|c|c|c|}
\hline \multirow[b]{2}{*}{ Sample } & \multirow{2}{*}{$\begin{array}{c}\mathrm{pH}_{(\text {paste }} \\
\text { (p) }\end{array}$} & \multirow{2}{*}{$\begin{array}{c}\mathrm{EC}^{\mathrm{a}} \\
(\mathrm{mmhos} / \\
\mathrm{cm})\end{array}$} & \multirow{2}{*}{$\begin{array}{l}\mathrm{Sat}^{\mathrm{b}} \\
(\%)\end{array}$} & \multicolumn{3}{|c|}{$\begin{array}{c}\text { Saturation } \\
\text { extiacl } \\
\text { cations } \\
\text { (meq/1) }\end{array}$} & \multirow[b]{2}{*}{$\mathrm{SAR}^{\mathrm{r}}$} & \multirow[b]{2}{*}{ ESPd } & \multicolumn{3}{|c|}{$\begin{array}{c}\text { Particle-sizc } \\
\text { analysis } \\
\text { hydromeler (\%) }\end{array}$} & \multirow[b]{2}{*}{ Texlure } & \multirow[t]{2}{*}{$\begin{array}{l}O M^{i} \\
(\%)\end{array}$} & \multirow{2}{*}{$\begin{array}{l}\text { Line } \\
(\%)\end{array}$} & \multirow[t]{2}{*}{$\begin{array}{l}\text { Total } \\
\text { boron } \\
\text { (ppm) }\end{array}$} & \multirow[t]{2}{*}{$\begin{array}{c}\text { Se } \\
(\mathrm{ppm})\end{array}$} \\
\hline & & & & $\mathrm{Ca}$ & $\overline{\mathrm{Mg}}$ & $\mathrm{Na}$ & & & Sand & Silt & Glay & & & & & \\
\hline FM1-1 & d. 1 & 0.2 & 85.3 & 1.1 & 0.9 & 0.1 & 04 & 0.7 & 89 & -1 & 7 & S.LS & 9.46 & 10.0 & 11.2 & $<0.01$ \\
\hline FM1-3 & 4.8 & 0.1 & 49.5 & 0.6 & 0.4 & 0.4 & 0.6 & 2.1 & 15 & 53 & 32 & $\mathrm{SiCL}$ & 6.10 & 9.8 & 62.8 & $<0.01$ \\
\hline FM1 -5 & 5.1 & 0.1 & 38.6 & 0.5 & 0.3 & 0.5 & 0.8 & 3.8 & 11 & 64 & 25 & SiL & 1.59 & 9.9 & 7.4 & $<0.01$ \\
\hline FM1-6 & 4.2 & 0.3 & 90.4 & 2.5 & 1.2 & 0.4 & 0.3 & 0.7 & 96 & 0 & 4 & $s$ & 8.63 & 9.0 & 38.9 & $<0.01$ \\
\hline FM1 -8 & 4.7 & 0.1 & 43.6 & 0.6 & 0.3 & 0.4 & 0.6 & 2.4 & 10 & 5.4 & 36 & SICL & 2.32 & 10.0 & 16.6 & $<0.01$ \\
\hline FM1 $\cdot 9$ & 4.6 & 0.1 & 69.6 & 1.1 & 0.5 & 0.4 & 0.4 & 1.1 & 46 & 10 & 44 & $\mathrm{SC} \cdot \mathrm{C}$ & 11.89 & 9.3 & 21.1 & $<0.01$ \\
\hline FMI-11 & 5.1 & 0.1 & 45.8 & 0.2 & $<0.1$ & 0.6 & 2.2 & 5.1 & 13 & 60 & 22 & SiL & 1.27 & 9.9 & 43.7 & $<0.01$ \\
\hline$F M d-12$ & 4,8 & 0.3 & 83.2 & 2.2 & 1.2 & 0.4 & 03 & 1.0 & 86 & 2 & 12 & LS & 856 & 8.8 & 36.1 & $<0.01$ \\
\hline FMI-14 & 7.2 & 0.4 & 43.0 & 3.1 & 1.6 & $0 . \overline{5}$ & 0.3 & 6.7 & 38 & 19 & 13 & L & 1.94 & 10.1 & 21.3 & 0.05 \\
\hline
\end{tabular}

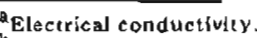

bsuluration percentagc.

Sodium adsorpuon ralio.

dExchangeable sodium percentage.

${ }^{e}$ - Clay

L - $1,02 \mathrm{~m}$

S. Sand

Bi - sill.

Organic inater.

Eation-exclinge eapacity.

heulralizallon polentalu

ipotentlal acidily (posilive values indicate excess $\mathrm{CaCO}_{3}$-basic overburcten maleral). 
on overburden, Belkgo River samples.

\begin{tabular}{|c|c|c|c|c|c|c|c|c|c|c|c|c|c|c|}
\hline \multicolumn{3}{|c|}{$\begin{array}{c}\text { Extraclable nutrients } \\
\text { (ppm) }\end{array}$} & \multicolumn{4}{|c|}{$\begin{array}{l}\text { Ammonium acetate } \\
\text { extractable cations } \\
\text { (meq/100 g) }\end{array}$} & \multirow{2}{*}{$\begin{array}{c}\text { CEC } \\
(\operatorname{meq} / 100 \mathrm{~g}) \\
\end{array}$} & \multirow{2}{*}{$\begin{array}{c}\text { Base } \\
\text { saturation } \\
(\%)\end{array}$} & \multirow{2}{*}{$\begin{array}{c}\mathrm{SO}_{4}-\mathrm{S} \\
(\%) \\
\end{array}$} & \multirow{2}{*}{$\begin{array}{l}\text { Pyritic } \\
\text { sulfix } \\
(\%) \\
\end{array}$} & \multirow{2}{*}{$\begin{array}{c}\text { Tolal } \\
\text { sulfur } \\
(\%) \\
\end{array}$} & \multirow{2}{*}{$\begin{array}{c}\text { Acid } \\
\text { potential } \\
\left.\text { meq } \mathrm{H}^{+} / 100 \mathrm{~g}\right) \\
\end{array}$} & \multicolumn{2}{|c|}{$\begin{array}{c}\text { Tons } \\
\mathrm{CaCO}_{3} / 1,000 \text { tons }\end{array}$} \\
\hline $\mathrm{NO}_{3}$ & $\mathrm{P}$ & $\mathrm{K}$ & $\mathrm{Ca}$ & $\mathrm{Mg}$ & $\mathrm{Na}$ & $K$ & & & & & & & $\overline{\mathrm{NPR}}$ & $\mathrm{PA}^{\prime \mathbf{n}}$ \\
\hline 2.4 & 29.82 & 147.7 & 11.3 & 6.8 & 0.7 & 0.2 & 24.4 & 75.8 & $<0.1$ & 0.01 & 0.04 & 2.5 & 14.69 & 13.44 \\
\hline 3.8 & 17.51 & 186.6 & 9.5 & 4.2 & 0.6 & 0.3 & 16.5 & 94.2 & $<0.1$ & 0.02 & 0.04 & 2.5 & 15.97 & 14.72 \\
\hline 4.7 & 10.35 & 198,8 & 9.3 & 3.2 & 0.7 & 0.3 & 2.0 & 100.0 & $<0.1$ & 0.09 & 0.10 & 6,3 & 125.68 & 122.54 \\
\hline 10.0 & 8.56 & 172.6 & 5.6 & 1.9 & 0.6 & 0.3 & 10.8 & 77.8 & $<0.1$ & 0.02 & 0.04 & 1.3 & 23.09 & 22.44 \\
\hline 3.8 & 23.85 & 280.4 & 15.6 & 4.2 & 0.7 & 0.7 & 23.0 & 92.2 & $<0.1$ & $<0.01$ & 0.06 & 3.8 & 10.03 & 8.13 \\
\hline 2.1 & 13.18 & 131.0 & 9.8 & 3.0 & 0.7 & 0.3 & 8.8 & 100.0 & $<0.1$ & 0.02 & 0.02 & 1.3 & 27.17 & 26.52 \\
\hline 5.8 & 12.74 & 140.7 & 11.3 & 4.4 & 0.7 & 0.3 & 8.3 & 100.0 & $<0.1$ & 0.01 & 0.01 & 0.8 & 12.13 & 11.83 \\
\hline 2.4 & 16.76 & 216.8 & 11.8 & 5.8 & 0.7 & 0.5 & 21.9 & 84.9 & $<0.1$ & 0.01 & 0.02 & 1.3 & 8.05 & 7.10 \\
\hline 9.1 & 16.82 & 196.0 & 0.2 & 3.0 & 0.7 & 0.6 & 13.6 & 100.0 & $<0.1$ & 0.01 & 0.01 & 0.6 & 31.02 & 30.72 \\
\hline 6.6 & 11.32 & 98.6 & 6.4 & 2.0 & 0.7 & 0.2 & 6.5 & 100.0 & $<0.1$ & 0.01 & 0.01 & 0.6 & 13.64 & 13.34 \\
\hline 13.8 & 18.60 & 251.7 & 11.1 & 5.7 & 0.7 & 0.6 & 18.3 & 98.9 & $<0.1$ & 0.01 & 0.01 & 0.0 & 34.40 & 84.40 \\
\hline
\end{tabular}

overburden, Fairview Mauntain samples.

\begin{tabular}{|c|c|c|c|c|c|c|c|c|c|c|c|c|c|c|}
\hline \multicolumn{3}{|c|}{$\begin{array}{c}\text { Extractable nutrients } \\
\text { (ppm) }\end{array}$} & \multicolumn{4}{|c|}{$\begin{array}{l}\text { Ammonium acetato } \\
\text { extractable ealions } \\
\text { (med/100 g) }\end{array}$} & \multirow{2}{*}{$\begin{array}{c}\text { CEC }^{R} \\
(\operatorname{meq} / 100 \mathrm{~g})\end{array}$} & \multirow{2}{*}{$\begin{array}{c}\text { Base } \\
\text { saturation } \\
\text { (\%) }\end{array}$} & \multirow{2}{*}{$\begin{array}{c}\mathrm{SO}_{4} \cdot \mathrm{S} \\
(\%)\end{array}$} & \multirow{2}{*}{$\begin{array}{l}\text { Pyritic } \\
\text { sulfur } \\
(\%)\end{array}$} & \multirow{2}{*}{$\begin{array}{l}\text { Tolal } \\
\text { sulfur } \\
(\%)\end{array}$} & \multirow{2}{*}{$\begin{array}{c}\text { Acid } \\
\text { potential } \\
\left(\text { meq } \mathrm{H}^{+} / 100 \mathrm{~g}\right)\end{array}$} & \multicolumn{2}{|c|}{$\begin{array}{c}\text { Tons } \\
\mathrm{CaCO}_{3} / 1,000 \text { Lons }\end{array}$} \\
\hline$\overline{\mathrm{NO}_{3}}$ & $P$ & $\overline{\mathrm{K}}$ & $\mathrm{Ca}$ & $\mathrm{Mg}$ & $\mathrm{Na}$ & $\mathrm{K}$ & & & & & & & $\mathrm{NP}^{\mathrm{T}}$ & $\overline{P A^{\prime}}$ \\
\hline 3.1 & 18.78 & 60.4 & 9.8 & 4.7 & 0.6 & $<0.1$ & 88.4 & 17.0 & $<0.1$ & 0.06 & 0.30 & 18.8 & 3.85 & -5.65 \\
\hline 3.3 & 14.30 & 113.7 & 10.1 & 6.4 & 0.6 & $<0.1$ & 29.0 & 55.2 & $<0.1$ & 0.02 & 0.06 & 3.8 & 7.23 & 5.33 \\
\hline 3.0 & 7.29 & 137.4 & 7.9 & 4.4 & 0.6 & 0.2 & 15.6 & 84.0 & $<0.1$ & 0.01 & 0.02 & 0.6 & 7.70 & 7.40 \\
\hline 3.4 & 15.80 & 47.6 & 10.2 & 2.9 & 0.6 & $<0.1$ & 81.5 & 16.7 & $<0.1$ & 0.01 & 0.48 & 30.0 & 9.56 & .5 .44 \\
\hline 3.1 & 14.90 & 144,1 & 9.8 & 4.0 & 0.8 & 0.2 & 24.6 & 59.3 & $<0.1$ & 0.02 & 0.02 & 1.3 & 5.01 & 4.36 \\
\hline 3.2 & 11.25 & 102.2 & 18.7 & 5.6 & 0.6 & $<0.1$ & 52.3 & 47.4 & $<0.1$ & 0.01 & 0.14 & 8.8 & 8.51 & 4.11 \\
\hline 2.8 & 14.68 & 134.8 & 7.2 & 2.7 & 0.6 & 0.1 & 11.7 & 90.6 & $<0.1$ & 0.01 & 0.01 & 0.6 & 8.30 & 6.00 \\
\hline 3,3 & 11.62 & 61.8 & 13.4 & 6.0 & 0.6 & $<0.1$ & 57.2 & 34.8 & $<01$ & 0.04 & 0.32 & 20.0 & 18.07 & 8.07 \\
\hline 3.1 & 8.19 & 70.6 & 7.2 & 2.5 & 0.6 & $<0.1$ & 9.0 & 100.0 & $<0.1$ & 0.04 & 0.04 & 1.9 & 26.47 & 25.52 \\
\hline
\end{tabular}


Table E-4. Chemical data on overburden, Canyon Creek site.

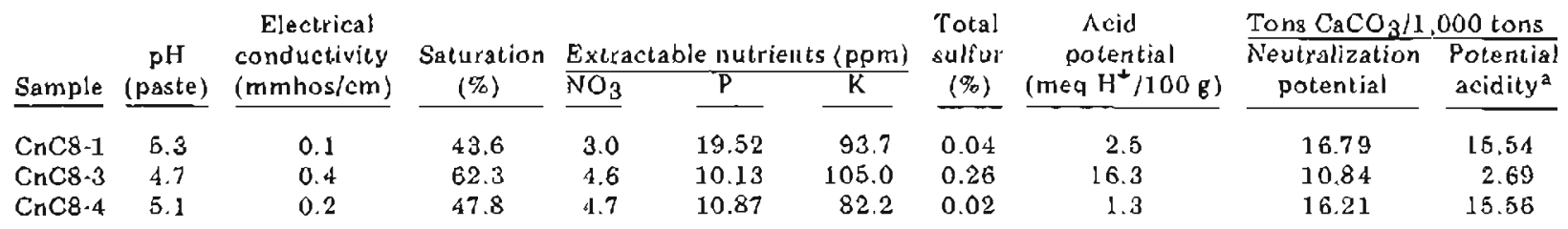

aposillve valuar indicale excess $\mathrm{CaCO}_{3}$ (basic overburden material).

Table E.5. Chemical dala on overburden, Johnson Creek samples.

\begin{tabular}{|c|c|c|c|c|c|c|c|c|c|c|}
\hline \multirow[b]{3}{*}{ Sample } & \multirow{3}{*}{$\underset{\text { (paste) }}{\mathrm{pH}}$} & \multirow{3}{*}{$\begin{array}{c}\text { Electrical } \\
\text { conductivity } \\
\text { (mmhos } / \mathrm{cm} \text { ) }\end{array}$} & \multirow{3}{*}{$\begin{array}{l}\text { Saturation } \\
\text { (\%) }\end{array}$} & \multirow{2}{*}{\multicolumn{3}{|c|}{$\begin{array}{l}\text { Extractable nutrients } \\
(\mathrm{ppm})\end{array}$}} & \multirow{3}{*}{$\begin{array}{c}\text { Total } \\
\text { sulfuy } \\
(\%) \\
\end{array}$} & \multirow{3}{*}{$\begin{array}{c}\text { Acid } \\
\text { potential } \\
\left(\text { mec } \mathrm{H}^{+} / 100 \mathrm{~g}\right)\end{array}$} & \multicolumn{2}{|c|}{ Tons $\mathrm{CaCO}_{3} / 1,000$ Lons } \\
\hline & & & & & & & & & Neutralization & Potential \\
\hline & & & & $\mathrm{NO}_{3}$ & $P$ & $\mathrm{~K}$ & & & polential & acidity ${ }^{\mathbf{3}}$ \\
\hline $\mathrm{JC} 3.2$ & 7.2 & 0.2 & 61.9 & 5.1 & 21.54 & 113.2 & 0.09 & 5.6 & 18.42 & 15.62 \\
\hline $\mathrm{JC} 3 \cdot 3$ & 6.3 & 0.1 & 50.3 & 3.6 & 21.17 & 134.3 & 0.02 & 1.3 & 16.67 & 16.02 \\
\hline JC3.4 & 6.7 & 0.2 & 68.2 & 4.1 & 38.54 & 153.2 & 0.15 & 9.4 & 8.28 & 3.58 \\
\hline $\mathrm{JC} 3.6$ & 6.7 & 0.2 & 47.2 & 2.2 & 17.81 & 223.0 & 0.02 & 1.3 & 14.58 & 13,93 \\
\hline
\end{tabular}

apogitive values indicace exoess $\mathrm{CaCO}_{3}$ (basic averburdan material).

Table E.6. Chemical daia on overburden, Wolverine Creek samples.

\begin{tabular}{|c|c|c|c|c|c|c|c|}
\hline \multirow[b]{2}{*}{ Sample } & \multirow[b]{2}{*}{$\begin{array}{c}\mathrm{pH} \\
\text { (paste) }\end{array}$} & \multirow{2}{*}{$\begin{array}{c}\text { Electrical } \\
\text { conductivity } \\
\text { (mmhos/cm) }\end{array}$} & \multirow[b]{2}{*}{$\begin{array}{c}\text { Saturation } \\
(\%) \\
\end{array}$} & \multirow{2}{*}{$\begin{array}{l}\text { Total } \\
\text { sulfur } \\
\text { (\%) }\end{array}$} & \multirow{2}{*}{$\begin{array}{c}\text { Acid } \\
\text { potential } \\
\text { (meq } \mathrm{H}^{+} / 100 \mathrm{~g} \text { ) }\end{array}$} & \multicolumn{2}{|c|}{ Tons $\mathrm{CaCO}_{3} / 1,000$ tons } \\
\hline & & & & & & $\begin{array}{c}\text { Neutralization } \\
\text { potential }\end{array}$ & $\begin{array}{l}\text { Potential } \\
\text { acidity }^{2}\end{array}$ \\
\hline WC2-1 & 6.4 & 0.3 & 35.8 & 0.02 & 1.3 & 19.59 & 18.84 \\
\hline WC2-2 & 6.5 & 0.5 & 58.6 & 0.03 & 1.9 & 36.73 & 35.78 \\
\hline WC2-3 & 5.9 & 0.5 & 72.8 & 0.20 & 12.5 & 33.00 & 26.76 \\
\hline WC2 -5 & 5.7 & 0.6 & 61.0 & 0.16 & 10.0 & 45,47 & 40.47 \\
\hline WC2.6 & 5.7 & 0.2 & 65.1 & 0.05 & 3.1 & 26.82 & 25.28 \\
\hline WC2.7 & 6.6 & 0.7 & 81.9 & 0.42 & 28.3 & 32.30 & 19.15 \\
\hline WC2.8 & 6.0 & 0.2 & 60.9 & 0.07 & 4.4 & 24.60 & 22.40 \\
\hline WC2-11 & 6.3 & 0.1 & 47.5 & 0.01 & 0.6 & 16.56 & 16.26 \\
\hline WC2-12 & 6.3 & 0.1 & 42.0 & 0,01 & 0.6 & 16.39 & 15.09 \\
\hline WC2-13 & 6.5 & 0.1 & 53.1 & 0.00 & 0.0 & 26.00 & 26.00 \\
\hline WC2-15 & 5.7 & 0.2 & 50.7 & 0.01 & 0.6 & 20.99 & 26.89 \\
\hline
\end{tabular}

${ }^{\mathrm{A}}$ Positive values indicate excess $\mathrm{CaCO}_{3}$ (basle overburden material). 
Table E-7. Physical and chemical data on overburden. Peters Hills area samples.

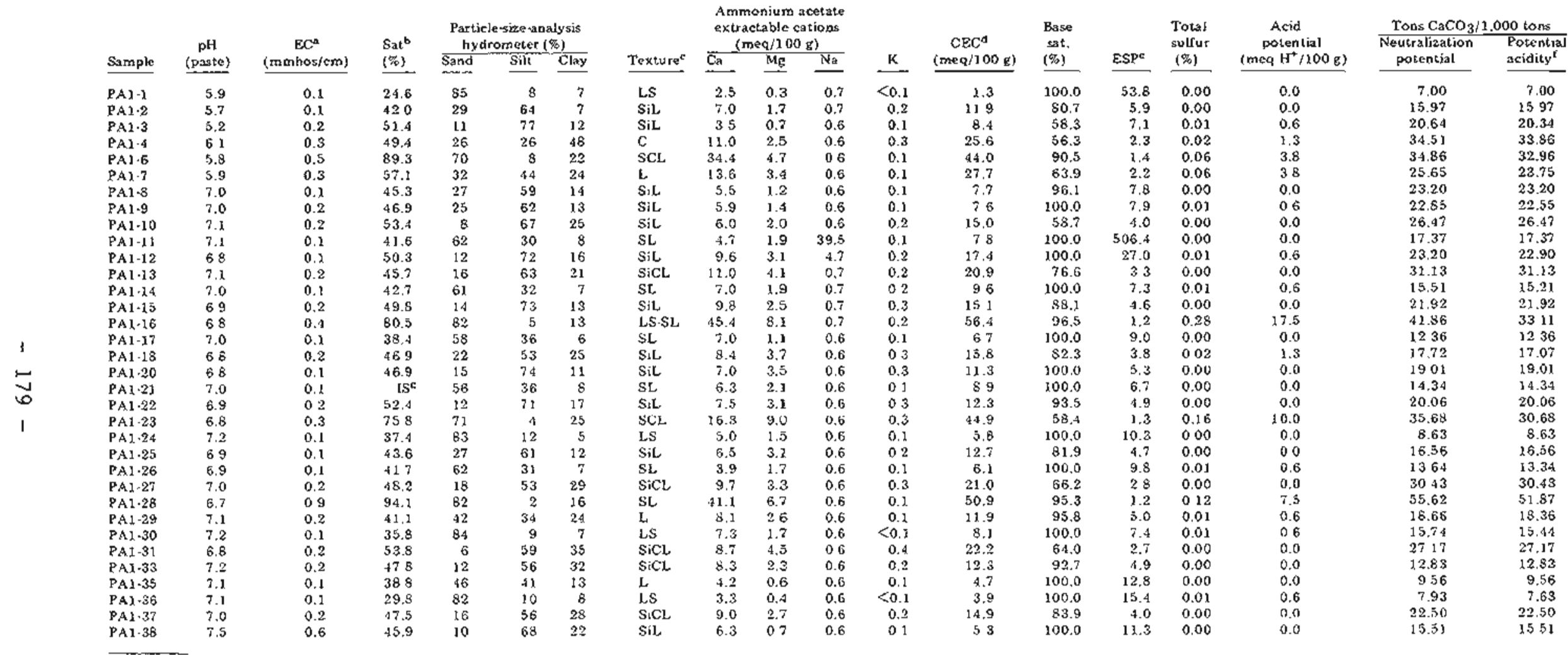


Table E-8. Chemical data on overburden, Saturday Creek samples.

\begin{tabular}{|c|c|c|c|c|c|c|c|c|c|c|c|c|c|c|c|c|c|c|}
\hline \multirow[b]{2}{*}{ Sample } & \multirow[b]{2}{*}{$\begin{array}{c}\mathrm{pH} \\
\text { (paste) }\end{array}$} & \multirow[b]{2}{*}{$\begin{array}{c}E C^{A} \\
(m m b s / c m)\end{array}$} & \multirow[b]{2}{*}{$\begin{array}{l}\text { Saturalion } \\
(\%) \\
\end{array}$} & \multicolumn{4}{|c|}{ Saturation } & \multirow[b]{2}{*}{$\begin{array}{l}O M^{\mathrm{C}} \\
(\%)\end{array}$} & \multirow[b]{2}{*}{$\begin{array}{l}\text { Lime } \\
(\%)\end{array}$} & \multirow[b]{2}{*}{$\frac{\text { Extractabl }}{\mathrm{NO}_{3}}$} & \multirow[b]{2}{*}{$\frac{\text { le nutrle }}{\mathrm{P}}$} & \multirow[b]{2}{*}{$\frac{\mathrm{nLE}}{\mathrm{N}}$} & \multirow[b]{2}{*}{$\begin{array}{c}\mathrm{SO}_{4} \mathrm{~S} \\
(\%)\end{array}$} & \multirow{2}{*}{$\begin{array}{l}\text { Pyritic } \\
\text { sulfur } \\
(\%)\end{array}$} & \multirow{2}{*}{$\begin{array}{l}\text { Tolal } \\
\text { sulfur } \\
(\%)\end{array}$} & \multirow{2}{*}{$\begin{array}{c}\text { Acid } \\
\text { potertial } \\
\left.\text { (maq } H^{+} / 100 \text { g) }\right)\end{array}$} & \multicolumn{2}{|l|}{ Tons $\mathrm{CaCO}_{3} 1$} \\
\hline & & & & $\frac{e x t r a c}{c a}$ & ention & $\left(\frac{m e g}{\sqrt{N_{a}}}\right)$ & $S A R^{\circ}$ & & & & & & & & & & $\begin{array}{l}\text { Neutralization } \\
\text { potential }\end{array}$ & $\begin{array}{l}\text { Polential } \\
\text { acidity }\end{array}$ \\
\hline $\mathrm{SC}_{4-1}$ & 6.0 & 0.1 & 44.7 & 0.1 & 0.2 & 0.5 & 1.3 & 0.82 & 9.9 & 33 & 1168 & 90.2 & $<0.1$ & 0.01 & 0.04 & 0.6 & 12.01 & 11.71 \\
\hline $\mathrm{SC}_{4} \cdot 3$ & 4.9 & 0.2 & 63,5 & 1.7 & 1.2 & 0.5 & 0.4 & 10,27 & 9,2 & 3.6 & 22.21 & 80.7 & $<0.1$ & 0.03 & 020 & 125 & 23.90 & 17.65 \\
\hline $\mathrm{SCA} L$ & 5.2 & 0.1 & 38.2 & 0.5 & 0.2 & 0.5 & $0 . B$ & 2.45 & 10.0 & 3.0 & 37.43 & 70.3 & $<0.1$ & 0.02 & 0.04 & 1.3 & 18.69 & 18.24 \\
\hline $\operatorname{SC} 46$ & 5.4 & 0.6 & 83.5 & 3.9 & 3.4 & 0.6 & $0-3$ & 11.55 & 8.8 & 2.1 & 10.80 & 86.1 & $<0.1$ & 0.04 & 0.14 & 8.8 & 38.83 & 34.43 \\
\hline $\operatorname{SC} 4-8$ & 5.3 & 0.4 & 64.5 & 2.8 & 2.4 & 0.5 & 0.3 & 11.42 & 9.0 & 9.1 & 15.57 & 89.9 & 60.1 & 0.03 & 0,12 & 7.5 & 31.37 & 27.62 \\
\hline SC4.9 & 5.3 & 0.1 & 43.8 & 0.7 & 0.3 & 0.5 & 0.7 & 4.33 & 9.8 & 3.6 & 1386 & 96.9 & $<0.1$ & 0.02 & 0.03 & 1.9 & 11.31 & 10.36 \\
\hline sct $4-1]$ & 5.3 & 02 & 45.6 & 2.0 & 0.6 & 0.5 & 0.6 & 5.08 & 10.0 & 30 & 19.08 & 81.4 & 801 & 0.04 & 0.04 & 2.5 & 21.80 & 20.55 \\
\hline$\$ C 4 \cdot 19$ & 5.0 & 0.1 & 44.1 & 0.3 & 0.1 & 05 & J. 1 & 2.22 & 10.0 & 2.9 & 6.85 & 148.5 & $<0.1$ & 0.01 & 0.02 & 0.6 & 9.33 & 903 \\
\hline
\end{tabular}

Ekeencil conducturty.

Erato.

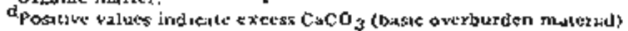

Tons $\mathrm{CaCO}_{3} / 1,000$ tons

\begin{tabular}{|c|c|c|c|c|c|c|c|c|c|c|c|c|}
\hline \multirow[b]{2}{*}{ Sample } & \multirow[b]{2}{*}{$\begin{array}{c}\mathrm{pH} \\
\text { (paste) }\end{array}$} & \multirow[b]{2}{*}{$\begin{array}{c}\mathrm{EC}^{\mathrm{a}} \\
(\mathrm{mmhos} / \mathrm{cm})\end{array}$} & \multirow[b]{2}{*}{$\begin{array}{l}\text { Saturation } \\
(\%)\end{array}$} & \multirow[b]{2}{*}{$\begin{array}{c}\text { Organic matter } \\
(\%)\end{array}$} & \multirow[b]{2}{*}{$\begin{array}{l}\text { Lime } \\
(\%)\end{array}$} & \multirow{2}{*}{\multicolumn{3}{|c|}{ Extractable nutrients (pm) }} & \multirow[b]{2}{*}{$\begin{array}{c}\text { Tohal sulfur } \\
(\%)\end{array}$} & \multirow[b]{2}{*}{$\begin{array}{l}\text { Acid potential } \\
\left.\text { (meq } \mathrm{H}^{+} / 100 \mathrm{~g}\right)\end{array}$} & \\
\hline & & & & & & & & & & & $\begin{array}{l}\text { Neutralization } \\
\text { potential }\end{array}$ & $\begin{array}{l}\text { Potential } \\
\text { acidity }\end{array}$ \\
\hline CG3-1 & 6.6 & 0.9 & 52.4 & 4.27 & 10.1 & 2.1 & 11.32 & 226.3 & 0.09 & 5.6 & 22.97 & 20.17 \\
\hline Co3-2 & 6.6 & 0.7 & 67.9 & 8.93 & 9.0 & 4.3 & 9.75 & 147.6 & 0.35 & 21.9 & 26.47 & 15.52 \\
\hline $\cos 3-3$ & 7.8 & 0.6 & 59.3 & 2.55 & 9.5 & 3.6 & 11.69 & 152.1 & 0.02 & 1.3 & 32.65 & 32.00 \\
\hline $\mathrm{CG} 3-4$ & 7.3 & 0.7 & 24.2 & 1.89 & 7.7 & 3.1 & 10.72 & 84.5 & 0.03 & 1.9 & 213.84 & 212.89 \\
\hline CG 35 & 7.4 & 0.6 & 58.2 & 2.61 & 9.9 & 3.7 & 12.07 & 397.4 & 0.04 & 2.5 & 29.03 & 27.78 \\
\hline CG3.7 & 7.0 & 0.3 & 50.6 & 4.35 & 9.8 & 4.2 & 7.07 & 208.4 & 0.05 & 3.1 & 41.98 & 40,43 \\
\hline CG3-8 & 6.3 & 0.6 & 86,6 & 8.89 & 9.4 & 3,4 & $8.7 \mathrm{I}$ & 137.7 & 0.38 & 23.8 & 34.16 & 22,26 \\
\hline CG $3-9$ & 6.7 & 0.2 & 54.9 & 2.88 & 9.9 & 2.3 & 15.65 & 169.2 & 0.02 & 1.8 & $\$ 7.26$ & 16.61 \\
\hline
\end{tabular}

"Electrical conductivity.

Fositive values indicate expess $\mathrm{CaCO}_{3}$ (basic overburden material). 
Table E-10. Suitability ratings for soils as sources of topsoiling material in Wyoming. From Wyaming Department of Environmental Quality, 1980.

\begin{tabular}{|c|c|c|c|c|}
\hline Parameter & Good & $\frac{\text { of soil sujtability }}{\text { Fair }}$ & Poor & Unsuitable \\
\hline $\mathrm{pH}$ & $6.0-8.4$ & $\begin{array}{l}5.5-8.0 \\
8.4 \cdot 8.8\end{array}$ & $\begin{array}{l}5.0-5.5 \\
8.8-9.0\end{array}$ & $\begin{array}{l}<6.0 \\
>9.0\end{array}$ \\
\hline $\begin{array}{l}\text { Conductivity (EC) } \\
\left(\text { mmhos } / \mathrm{cm} @ 25^{\circ} \mathrm{C}\right)\end{array}$ & $<4$ & $4-8$ & $8 \cdot 16$ & $>16$ \\
\hline $\begin{array}{l}\text { Saturation percentage } \\
\text { (SP) (\%) }\end{array}$ & $25 \cdot 80$ & & $\begin{array}{l}>80 \\
<25\end{array}$ & \\
\hline Texture class & SL, L, SiL, SCL & CL, SiCL, SC, LS & $\mathrm{C}, \mathrm{SiC}_{2} \mathrm{~S}$ & \\
\hline $\begin{array}{l}\text { Sodium adsorption } \\
\text { ratio (SAR) }\end{array}$ & $<6$ & $8-10$ & $10 \cdot 15$ & $>15$ \\
\hline Calcium carbonate (\%) & $\begin{array}{l}\text { Low } \\
\text { (none-slight) } \\
0-15\end{array}$ & $\begin{array}{l}\text { Moderate } \\
15.30\end{array}$ & $\begin{array}{l}\text { High } \\
>30\end{array}$ & \\
\hline Moist consistence & Friable & Loose, firm & Very firm & \\
\hline Dry consislence & Loose, soft & $\begin{array}{l}\text { Slightly hard, } \\
\text { hard }\end{array}$ & Very hard & \\
\hline $\begin{array}{l}\text { Selenium (ppm) } \\
\text { Boron (ppm) } \\
\text { Molybdenum (ppm) } \\
\text { NOß (ppm) }\end{array}$ & $\begin{array}{l}<2 \\
<5 \\
<5 \\
<5\end{array}$ & ct) & & pect) \\
\hline
\end{tabular}

Table E-11. Suspect levels in averburden material of Montana. From Dollhopf and others, 1978, v. 1, p. 43.

\begin{tabular}{|c|c|}
\hline Parameler & Suspect level \\
\hline 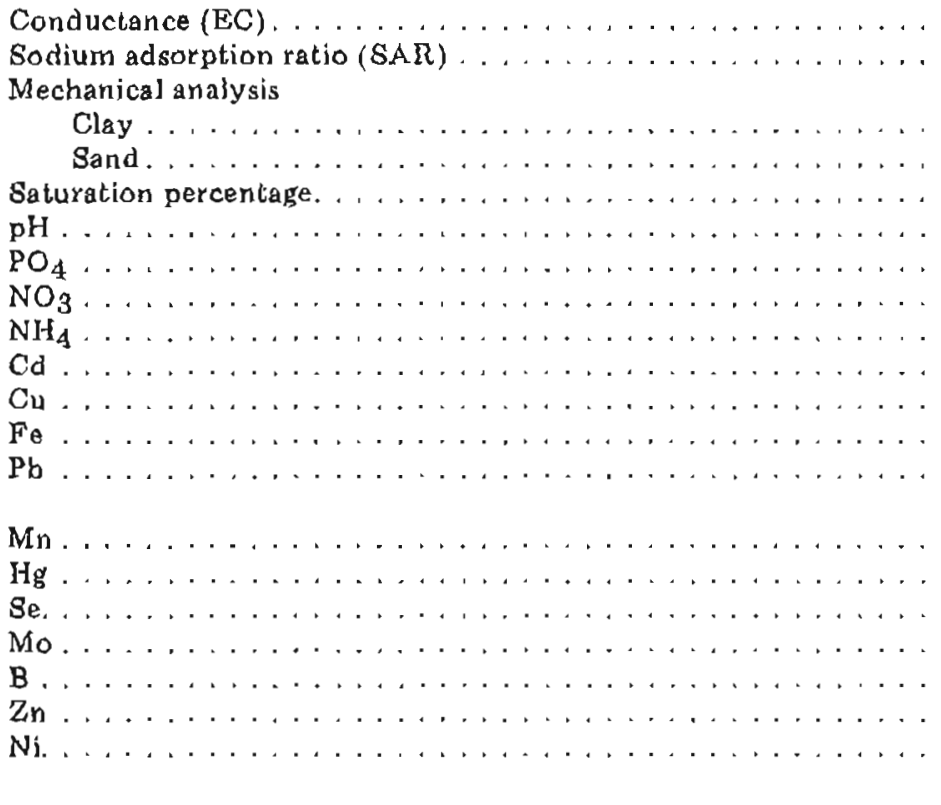 & $\begin{array}{l}>4-6 \mathrm{mmhos} / \mathrm{cm} \\
>12 \\
>40 \% \\
>70 \% \\
\text { None } \\
>8.8-9.0 \\
\text { None } \\
>10-20 \mathrm{ppm} \\
>10.20 \mathrm{ppm} \\
>0.1 .1 .0 \mathrm{ppm} \\
>40 \mathrm{ppm} \\
\text { Unknown } \\
\mathrm{pH}<6 .>10-15 \mathrm{ppm}^{8} \\
\mathrm{pH}<8,>15-20 \mathrm{ppm}^{\circ} \\
>60 \mathrm{ppm} \\
>0.4-0.5 \mathrm{ppm} \\
>2.0 \mathrm{ppm} \\
>0.3 \mathrm{ppm}^{\circ} \\
>8.0 \mathrm{ppm} \\
>30-40 \mathrm{ppm}^{\circ} \\
>1.0 \mathrm{ppm} \\
>5.0 \mathrm{ppm}^{\circ}\end{array}$ \\
\hline
\end{tabular}




\section{STAFF ${ }^{1}$}

Robert B. Forbes, State Geologist

Thomas E. Smith, Deputy State Geologist

\section{AdmInistrative Services}

P.M. Verosta, Administrative Assistant ${ }^{2}$

K.E. Brown, Clerk Typist

R.A. Czajka, Clerk Typist

R.R. Groner, Accounting Technician

M.G. Murphree, Clerk Typist

J.M. Robinson, Administrative Assistant

J.L. Weir, Field Office Assistant

Energy Resources

G.H. Pessel, Geologist ${ }^{2}$

J.G. Clough, Geologist

S.A. Liss, Geologist

R.J. Motyka, Geologist

C.G. Mull, Geologist

J.W. Reeder, Geologist

R.R. Reifcnstuhl, Geologist

M.S. Robinson, Gcologisi

\section{Engineering Geology}

R.A. Combellick, Geologist ${ }^{2}$

G.D. March, Geologist

C.J. Nye, Gcologist

R.D. Reger, Geologist

M.A. Wiltse, Chemist

Minerals and Materials Development

W.G. Gilbert, Geologist ${ }^{2}$

T.K. Bundtzen, Geologist

L.E. Burns, Geologist

K.H. Clautice, Geologist

E.E. Harris, Geologist

J.T. Kline, Geologist

D.N. Solie, Geologist
Resource Information

G.M. Laird, Publications Specialist ${ }^{2}$

K.E. Adams, Publications Technician

R.A. Mann, Clerk

J.A. Outten, Clerk Typist

A-L. Schell, Caslographer

A.F. Seward, Publications Technician

A.G. Sturmann, Cartographer

\section{Water Resources}

W.E. Long, Hydrologist ${ }^{2}$

R.D. Alley, Hydrologist

S.J. Carrick, Hydrologist

M.G. Inghram, Hydrologist

R.W. Ireland, Hydrologist

D.L. LaSage, Hydrologist

M.A. Maurer, Hydrologist

M.A. Moorman, Hydrologist

J A. Munter, Hydrologist

R.S. Noll, Hydrologist

W.A. Petrik, Hydrologist

S.R. Ray, Hydrologist

\footnotetext{
In addition to the permanent stafr listed above, DGGS prescritly eniploys 14 studenis in the Deparlment of Nalural Resources Student Intern Progran.

${ }^{2}$ Section chicf.
} 